\section{CORPORATE OWNERSHIP \& CONTROL}

\section{КОРПОРАТИВНАЯ СОБСТВЕННОСТЬ И КОНТРОЛЬ}

Postal Address:

Postal Box 36

Sumy 40014

Ukraine

Tel: $+380-542-698125$

Fax: +380-542-698125

e-mail: alex_kostyuk@virtusinterpress.org

www.virtusinterpress.org

Journal Corporate Ownership \& Control is published four times a year, in September-November, December-February, March-May and June-August, by Publishing House "Virtus Interpress", Kirova Str. 146/1, office 20, Sumy, 40021, Ukraine.

Information for subscribers: New orders requests should be addressed to the Editor by e-mail. See the section "Subscription details".

Back issues: Single issues are available from the Editor. Details, including prices, are available upon request.

Advertising: For details, please, contact the Editor of the journal.

Copyright: All rights reserved. No part of this publication may be reproduced, stored or transmitted in any form or by any means without the prior permission in writing of the Publisher.

Corporate Ownership \& Control

ISSN 1727-9232 (printed version) 1810-0368 (CD version) 1810-3057 (online version)

Certificate № 7881

Virtus Interpress. All rights reserved.
Почтовый адрес редакции:

Почтовый ящик 36

г. Сумы, 40014

Украина

Тел.: 38-542-698125

Факс: 38-542-698125

эл. почта: alex_kostyuk@virtusinterpress.org www.virtusinterpress.org

Журнал "Корпоративная собственность и контроль" издается четыре раза в год в сентябре, декабре, марте, июне издательским домом Виртус Интерпресс, ул. Кирова 146/1, г. Сумы, 40021, Украина.

Информация для подписчиков: заказ на подписку следует адресовать Редактору журнала по электронной почте.

Отдельные номера: заказ на приобретение отдельных номеров следует направлять Редактору журнала.

Размещение рекламы: за информацией обращайтесь к Редактору.

Права на копирование $u$ распространение: копирование, хранение и распространение материалов журнала в любой форме возможно лишь с письменного разрешения Издательства.

Корпоративная собственность и контроль

ISSN 1727-9232 (печатная версия) 1810-0368 (версия на компакт-диске) 1810-3057 (электронная версия)

Свидетельство КВ 7881 от 11.09.2003 г.

Виртус Интерпресс. Права защчищены. 


\section{EDITORIAL}

Dear readers!

The recent issue of the journal Corporate Ownership and Control pays attention to issues of executive compensation, investments risks management, corporate audit issues, corporate codes etc. Board of drectors issues and peculiarities of corporate governance in developing countries are also under the scope of researches. More detailed issues are given below.

Antony Jackson shows that the presence of asymmetric information can also provide a positive externality to those market participants who operate in multiple markets-portfolio managers. Udo $C$. Braendle and John E. Katsos studying intrinsic and extrinsic incentives argue that shareholders' failure to provide the right balance to motivate senior managers to perform at their best is not the result of compensation packages as such, but on the focus of compensation packages on extrinsic motivators such as pay-for-performance bonuses and stock options. N.J. Godi and J. Young aim to identify risks which investors are exposed to when investing offshore and ranking these risks in order of importance, based on a literature review as well as views and experiences of South African investment brokers registered with the Financial Services Board. Silvia Testarmata, Alessia Montecchia and Emiliano Di Carlo focuse on the disclosure of environmental sustainability in codes of ethics, investigating the case of Italian listed companies. Michalis Bekiaris, Thanasis Efthymiou and Andreas G. Koutoupis record the current situation regarding the mode of interaction of the economic crisis in corporate governance and risk management.

Kiridaran Kanagaretnam, Gerald J. Lobo and Dennis J. Whalen examine the relationship between board independence and firm performance over multiple years, post-Sarbanes Oxley. Tsun-Jui Hsieh and $Y u$-Ju Chen investigate the impact of outside directors on firm performance during legal transitions and examine how the roles of family business and director compensation influence board efficacy.

Andre Carvalhal, Cesar Martins and Otavio Figueiredo analyze the relation between stock price changes and high volume trades in Brazil. Using a unique intra-day database, authors evaluate 10 of the most liquid shares from 2001 to 2006. F Cronje, J.H. van Rooyen single out and demonstrate the effect of the minimum capital requirements on the profitability, composition and size of a bank balance sheet. Research is base on South African data.

We hope that you will enjoy reading the journal and in future we will receive new papers, outlining the most important issues and best practices of corporate governance! 


\section{CORPORATE OWNERSHIP \& CONTROL}

\section{VOLUME 11, ISSUE 1, FALL 2013}

CONTENTS

EDITORIAL

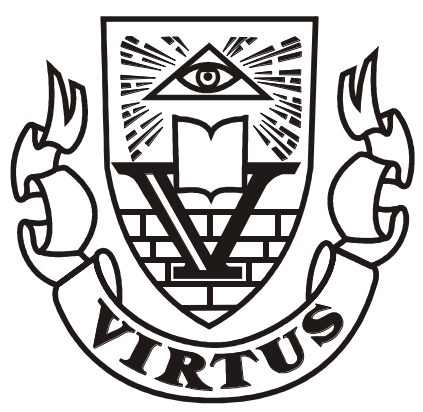

4

\section{SECTION 1. ACADEMIC INVESTIGATIONS AND CONCEPTS \\ ASYMMETRIC INFORMATION, TRADING VOLUME, AND PORTFOLIO PERFORMANCE}

\section{Antony Jackson}

In this paper, author shows that the presence of asymmetric information can also provide a positive externality to those market participants who operate in multiple markets-portfolio managers. Specifically, insiders lower the estimation errors of portfolio selection methods, thus improving asset allocation. Author develops multiple artificial markets, in which portfolio managers trade alongside informed and uniformed speculators, and researcher contrasts the performance of 'volatility timing'-a method that relies on efficient price discovery-with that of 'naive diversification'. Volatility timing is shown to consistently outperform naive diversification on a risk-adjusted basis.

\section{HOW TO CONTROL THE CONTROLLER - CEO COMPENSATION AND MOTIVATION}

\section{Udo C. Braendle, John E. Katsos}

One of the main control mechanisms that shareholders have used to rein in rogue managers is compensation. Through a combination of intrinsic and extrinsic incentives, shareholders have tried to provide the right balance to motivate senior managers to perform at their best. Shareholders have often failed in achieving this balance through compensation. In this paper, authors argue that this failure is not the result of compensation packages as such, but on the focus of compensation packages on extrinsic motivators such as pay-for-performance bonuses and stock options. Instead, the focus of compensation packages should be on cultivating intrinsic motivators such as firing and prestige.

\section{N.J. Godi, J. Young}

When investors engage in international business, transactions and operations, they encounter additional risks compared to trading domestically. Different languages, currencies, jurisdictions, customs and habits can be translated into extra informational asymmetries and transaction costs that may affect the smooth operation of business. Political transitions can also play an important role in the success of an offshore investment, especially in a world full of political uncertainty. As such, mitigating offshore risks is a significant factor in the success of overseas projects, investments and contracts. As such, this paper aims to identify risks which investors are exposed to when investing offshore and ranking these risks in order of importance, based on a literature review as well as views and experiences of South African investment brokers registered with the Financial Services Board. 


\section{ENHANCING ENVIRONMENTAL SUSTAINABILITY THROUGH CODES OF ETHICS: THE CASE OF ITALIAN LISTED COMPANIES}

\section{Silvia Testarmata, Alessia Montecchia, Emiliano Di Carlo}

Codes of ethics aim to disclose corporate social responsibility and to promote ethical culture throughout the firms. Several studies have investigated the content of such codes to identify what values are declared within. However, so far literature on codes of ethics seems not to have considered adequately the question of environmental protection. Therefore this paper focuses on the disclosure of environmental sustainability in codes of ethics, investigating the case of Italian listed companies. Adopting a content analysis methodology, the paper explores the environmental section of these codes in order to assess the salience of environmental sustainability in the strategic orientation of the firms, identifying the environmental principles, objectives, instruments and certification stated within the codes of ethics and highlighting whether and to what extent the environmental disclosure varies among industries. The research findings suggest that the Italian listed companies are more oriented to emphasize the environmental principles rather than to define precise objectives and instruments useful to achieve the environmental sustainability in practice. Nevertheless the more polluted industries seem to provide a wider environmental disclosure.

\section{ECONOMIC CRISIS IMPACT ON CORPORATE GOVERNANCE \& INTERNAL} AUDIT: THE CASE OF GREECE

\section{Michalis Bekiaris, Thanasis Efthymiou, Andreas G. Koutoupis}

The purpose of this paper, is to record the current situation regarding the mode of interaction of the economic crisis in corporate governance and risk management. This is achieved by conducting research which underpins the distribution of structured questionnaires in Greeks professionals. In this way, it is presented a substantial imprinting of Greek views on a number of issues arising from the investigation of the above relation. In order to gather as much as possible essential information, it is performed a comparison of these global positions, by surveys carried out by the IIA, which had almost the same content. The conclusion is that the current economic conditions require a more effective form of corporate governance, while the three main weaknesses mentioned above are the areas that more focus should be given. Additionally, the most important factor that could highlight all risks in time is to perform audits on liquidity, capital and balance sheet consolidation. Still, there is a view that the ERM failed to recognize timely the danger of imminent economic crisis. Finally, budgets on internal audit have increased significantly, both in national and international level, while in the future the internal audit itself should have as a priority to consult the board, in order to identify, manage and monitor the key risks.

\section{SECTION 2. CORPORATE BOARD PRACTICES}

\section{RELATIONSHIP BETWEEN BOARD INDEPENDENCE AND FIRM PERFORMANCE POST-SARBANES OXLEY}

\section{Kiridaran Kanagaretnam, Gerald J. Lobo, Dennis J. Whalen}

Authors examine the relationship between board independence and firm performance over multiple years, post-Sarbanes Oxley. Authors hypothesize and find that the passage of Sarbanes Oxley, together with the new NYSE/NASDAQ regulations, result in independent directors who are more effective monitors of management, leading to stronger firm performance. Results should bolster investor confidence in the financial markets at a time when the NYSE/NASDAQ has strengthened the corporate governance standards for listed companies. 


\section{FAMILY BUSINESS, DIRECTOR COMPENSATION AND BOARD EFFICACY: THE} CASE OF TAIWAN

\section{Tsun-Jui Hsieh, Yu-Ju Chen}

This paper investigates the impact of outside directors on firm performance during legal transitions and examines how the roles of family business and director compensation influence board efficacy. By using Taiwanese listed companies as the sample, the empirical results show that outside directors who are appointed by legal mandate have less positive impacts on firm performance than outside directors appointed voluntarily. Family business weakens the positive impact of outside director on firm performance. The evidence further suggests that director compensation contributes to firm performance, particularly when outside directors are voluntarily appointed. The findings provide western managers with an understanding of how the typical Chinese family business affects board independence. Authors also demonstrate and incorporate the cultural and the ownership characteristics into the analysis to present a country-specific pattern that should be informative for foreign investors who are concerned about the quality of corporate governance in East Asia.

\section{SECTION 3. CORPORATE GOVERNANCE IN DEVELOPING CONTRIES}

HIGH VOLUME TRADES AND STOCK PRICE CHANGES IN BRAZIL

\section{Andre Carvalhal, Cesar Martins, Otavio Figueiredo}

This work analyzes the relation between stock price changes and high volume trades in Brazil. Using a unique intra-day database, authors evaluate 10 of the most liquid shares from 2001 to 2006. Unlike most international studies, which are based on data from funds or institutional investors, this article breaks new ground by working with publicly available information. Results indicate a positive and significant relation between stock price changes and high volume trades. In line with existing literature, the paper shows there are both temporary and partially permanent on stock prices after high volume trades. Study also indicates the existence of asymmetry between purchases and sales.

\section{A CRITICAL EVALUATION OF THE SENSITIVITY OF A BANK'S BALANCE SHEET TO CHANGE WHEN OPTIMIZING FOR CAPITAL REQUIREMENTS UNDER BASEL}

\section{F Cronje, J.H. van Rooyen}

This research was to single out and demonstrate the effect of the minimum capital requirements on the profitability, composition and size of a bank balance sheet. It is clear from the research that banks are very sensitive to the new regulation. It also underlines how difficult it may be for banks to maintain profitability. The changes needed to maintain the profitability, may not be possible/feasible in the South African financial environment. The time is possibly right now for banks to start improving efficiency and developing new innovative low risk high return services and product lines. 


\title{
ASYMMETRIC INFORMATION, TRADING VOLUME, AND PORTFOLIO PERFORMANCE
}

\begin{abstract}
Antony Jackson*
Abstract

In dealership markets, asymmetric information feeds through to higher transaction costs as dealers adjust their bid-ask spreads to compensate for anticipated losses. In this paper, we show that the presence of asymmetric information can also provide a positive externality to those market participants who operate in multiple markets-portfolio managers. Specifically, insiders lower the estimation errors of portfolio selection methods, thus improving asset allocation. We develop multiple artificial markets, in which portfolio managers trade alongside informed and uniformed speculators, and we contrast the performance of 'volatility timing'-a method that relies on efficient price discovery - with that of 'naive diversification'. Volatility timing is shown to consistently outperform naive diversification on a risk-adjusted basis.
\end{abstract}

Keywords: Asymmetric Information, Portfolio Selection, Stochastic Simulation

JEL Classification: D82, G11, G12

* School of Economics, Vniversity of East Anglia, Norwich $\mathcal{N} \overline{4}$ 7TJ', United Kingdom

Tel.: +44(0)1603 593876

E-mail: antony.jackson@uea.ac.uk,

\section{Introduction}

In market microstructure models, transaction costs arise endogenously - either through the inventory management process of the monopolist (Ho and Stoll, 1981), or through the asymmetric information advantage of insiders (Glosten and Milgrom, 1985). Repeated iteration of the Glosten and Milgrom (1985) model generates intra-day price dynamics via the price setting behavior of a market maker responding to the flow of orders arriving from a large pool of informed and uninformed traders. The degree to which intra-day prices 'discover' true fundamental value depends on how sensitive the dealer's priors are to the flow of new orders. The dealer adjusts prices most rapidly when the proportion of informed trade and the volume of orders are high.

In this paper, we study the effects of asymmetric information in the wider context of multiple asset markets. In an individual market, a higher probability of informed trade unambiguously leads to higher transaction costs. We suggest, however, that there are subtle benefits of asymmetric information that accrue to those who operate across many markets: portfolio managers. The reason is that portfolio selection methods rely to various degrees on efficient price discovery - the ability of the market mechanism to accurately reflect underlying fundamentals. We argue that 
private information counteracts the impediment to price discovery inherent in low trading volume, and that there appears to be an optimal level of private information, given the other characteristics of a particular market.

Our approach is to simulate multiple assets with correlated fundamentals. In our dealership markets, insiders act as the conduit between fundamentals and prices. To assess the costs and benefits of asymmetric information to portfolio managers, we contrast the performance of a strategy that relies on efficient price discovery - the volatility timing strategy - with naive diversification. This choice partly reflects recent developments in the portfolio choice literature, but also reflects our preference for methods that offer the practical advantage of rapid computation.

Attention has recently focused on portfolio management strategies that avoid the problems associated with full mean-variance optimization: singularity in the covariance matrix of returns, and excessive volatility in asset allocations. Restrictions are placed on elements of the covariance matrix, or 'shrinkage' estimators are formed as weighted sums of the sample covariance matrix and a simple 'target' matrix; see, for example, Jagannathan and Ma (2003) and Tu and Zhou (2011). The naive diversification strategy (DeMiguel et al., 2009) entirely removes the need for an estimated covariance matrix, instead allocating an equal share of capital to all portfolio constituents. The volatility timing strategy (Kirby and Ostdiek, 2012) is more involved - basing its allocation on relative volatilities calculated using moving windows of asset prices. Both strategies share the characteristics of full capital allocation and no-short-sales.

The approach of this paper is to take advantage of the simple Bayesian updating mechanism offered by the binomial branching structure of the sequential trade model (Glosten and Milgrom, 1985), while retaining the original statistical properties of the full multivariate simulation of underlying fundamental values. This is achieved by mapping multivariate normal returns into their Bernoulli equivalents, a process that requires boosting the elements of the original covariance matrix (Einrich and Piedmonte, 1991). Our simulation methodology does not place any restrictions on the number of portfolio constituents. Covariance matrices are randomly generated using a wide range of parameter values within a singleindex factor model. We generate multivariate asset returns using the Cholesky factorization of these matrices, which requires matrix inversion, but we address the potential singularity problem by reconstructing those matrices with negative eigenvalues (Rebonato and Jackel, 1999).

A further innovation of this paper is to borrow the recombining tree structure of the
Cox et al. (1979) binomial options pricing model. We replace the risk-neutral probabilities of Cox et al. (1979) with the probabilities implied by a single-index model with drift. Multiple markets are linked together by the correlations between their fundamental values. The recombining tree structure lays the foundation for future research on the stochastic arrival of information, as it keeps the dealer's Bayesian updating task manageable. Information arrives at the beginning of each trading period, with true values revealed at the end of each period.

We draw an important distinction between the trading population that generates prices (uninformed and informed speculators), and portfolio managers who act upon multiple asset prices. A feature of the Glosten and Milgrom (1985) model is that as the dealer processes orders, the uncertainty of the true underlying value diminishes, in turn leading to narrower bid-ask spreads. If we were to posit portfolio managers as arriving randomly during the session - like the rest of the population - we would also randomly vary the impact of transaction costs. We prefer instead to place all portfolio manager trades at the opening bid- ask spreads of each period, which enables transaction costs to be a pure function of the probability of informed trade. This abstraction also enables us to sidestep the tricky issue of strategic behavior when market participants trade more than a single unit. Portfolio managers in our model are able to accurately signal to the dealer that they are uninformed. In concurrent research, we consider the liquidity cost that must be borne by portfolio managers who are unable to naturally differentiate themselves from the rest of the population. In this version, portfolio managers operate in multiple 'Kyle' auction markets (Kyle, 1985).

The final bid-ask spread of each session is used to calculate the session 'close'. Portfolio managers mark their holdings to market using closing prices. The day-to-day changes in account value imply a series of strategy returns, with mean returns and risk-adjusted returns (Sharpe ratio) following. In addition, volatility timing managers use closing prices in the volatility calculations that determine their asset allocations. This is why trading volume and the probability of informed trade have a joint influence on the performance of the volatility timing strategy. A large flow of orders makes it easier for the dealer's posterior probabilities to converge to the true probabilities, but unless there is a sufficient level of informed trade, even high volume may be insufficient for efficient price discovery. In the extreme, with an entirely uninformed population, a competitive, riskneutral dealer quotes a single bid/ask price, and sees no reason to adjust the price in response to trading volume. Instead, the price jumps each time 
the changes in fundamental value become common knowledge.

The model of fundamentals presented in Section 2 generates multivariate normal returns using a single index factor model. Individual assets are characterized by the sensitivity of their returns to movements in the market index, and through the portfolio's correlation matrix. These data determine the sizes and probabilities of 'up' and 'down' movements in our Cox et al. (1979) discretization scheme. Intra-day trade takes place in individual competitive markets that are indirectly connected by the insiders who make decisions based on private access to fundamental information. The latest change in fundamental value is made common knowledge at the end of each day, with dealers adjusting their opening spreads accordingly. Although beyond the scope of the current paper, the recombining structure of the Cox et al. (1979) scheme allows the revelation of information to occur stochastically, whilst keeping the dealer's updating task manageable. A natural way to do this is to use a geometric distribution to randomly select the release of 'news announcements'.

Section 2 also describes the Einrich and Piedmonte (1991) procedure for transforming multivariate normal random variables into their Bernoulli equivalents. We describe the Rebonato and Jackel (1999) method for dealing with singular correlation matrices, and list the parameter assumptions used in constructing our various portfolios.

Section 3 describes the model we use to create intra-day price dynamics and closing prices. We derive probability updating equations in terms of the probabilities of informed trade and the probability of value rising. The sizes of price movements, and their probabilities of occurrence, feed from Section 2.

Once the time series of opening and closing prices has been generated, we test the performance of the naive diversification and volatility timing strategies. In Section 4, upon observing the vector of opening bid-ask quotes, each manager re-values his current positions, and calculates his desired holdings. The naive diversification manager allocates capital equally between assets, whereas the volatility timing manager allocates capital using rolling estimates of volatility.

In Section 5, we present the results, and we use nonparametric methods to identify the key drivers of portfolio performance. The key driver of mean returns is the probability of informed trade, while the key driver of the Sharpe ratio statistic is the strategy type.

The determinants of the highest mean return are intuitively straightforward: substantial volume in illiquid states, combined with low probabilities of informed trade. The determinants of a strategy's Sharpe ratio offer a more interesting story. The
Sharpe ratios of the volatility timing strategy dominate those of the naive diversification strategy across all market conditions. Since mean returns are not driven by strategy type, it must be that the volatility timing strategy offers improved riskadjusted returns via lower risks. There are substantial improvements in the volatility timing strategy's risk-adjusted performance as the number of assets in the portfolio is increased, but the most intriguing driver is the probability of informed trade-the Sharpe ratios corresponding to a $1 \%$ probability of informed trade are lower than those corresponding to higher probabilities. Evidently, the volatility timing strategy benefits from the improved price discovery offered by 'reasonable' levels of asymmetric information, but these gains are eventually overwhelmed by higher transaction costs.

The paper concludes with suggestions for future research. In particular, our recombining tree structure allows for staggered news arrivals, without the need for great complexity in the dealer's Bayesian updating problem. The use of a geometric distribution for the timing of news arrivals would seem a sensible start, with insiders maintaining their informational advantage at all times.

\section{Fundamentals}

The log-returns of the portfolio constituents' fundamental values are multivariate normally distributed. The returns generating process is assumed to be a single-index model, where the return on the risk-free asset is normalized to zero. An individual asset's expected returns are a simple function of its beta coefficient and the expected return to the market index:

$$
r_{i}=\beta_{i} r_{m},
$$

where $r_{i}$ denotes the expected return to asset $i$, and $r_{m}$ denotes the expected return to the market index. The beta coefficient $\beta_{i}$ is defined by

$$
\beta_{i}=\frac{\sigma_{i, m}}{\sigma_{m}^{2}}
$$

and measures the ratio of the covariance of the returns to an asset and those of the market index to the variance of the returns to the market index.

The expected return to the market index is assumed to be constant, $r_{m}=10 \%$ p.a., with a constant annual volatility of $\sigma_{m}=20 \%$ p.a. Individual volatilities $\sigma_{i}$, betas $\beta_{i}$, and pairwise correlations $\rho_{i, j}$ are drawn independently from various uniform distributions. Table 1 lists the various specifications. Each asset's annual volatility is assumed to lie in the range 5\% to $40 \%$, and its beta coefficient in the range 0.50 to 1.50 . The pairwise correlation coefficient between assets 
lies in the range 0.00 to 1.00 . These parameter distributions are chosen to allow for a wide range of volatilities, as well as a variety of relationships with the market index.

Table 1. Simulation Parameter Distributions

\begin{tabular}{|ccc|}
\hline Parameter & Description & Value \\
\hline$n$ & Number of portfolios & 1000 \\
$N$ & Number of portfolio constituents & $\{2,5,10\}$ \\
$\sigma_{m}$ & Market Index volatility (p.a.) & $20 \%$ \\
$r_{m}$ & Market Index expected return (p.a.) & $10 \%$ \\
$\sigma_{i}$ & Asset $i$ volatility (p.a.) & Uniform $(5 \%, 40 \%)$ \\
$\beta_{i}$ & Asset $i$ beta & Uniform $(0.50,1.50)$ \\
$\rho_{\mathrm{i}, \mathrm{j}}$ & Correlation $(i, j)$ & Uniform $(0.00,1.00)$ \\
\hline
\end{tabular}

Each portfolio consists of 2, 5, or 10 stocks. For each of these different portfolio sizes, we simulate 1000 portfolios using randomly-generated correlation matrices. We assume that each $\rho_{\mathrm{i}, \mathrm{j}}(i \neq$ $j$ ) is drawn independently from a continuous uniform distribution with range

$[0,1]$. The elements along the main diagonal are set to 1 , and those below the main diagonal are set (by symmetry) according to $\rho_{\mathrm{j}, \mathrm{i}}=\rho_{\mathrm{i}, \mathrm{j}}$. The resulting correlation matrix $\mathbf{C}$ is used to generate multivariate normal random variables. In order to be compatible with the simple intra-day sequential trade model, these multivariate random variables are then transformed to Bernoulli random variables.

The sizes of fundamental value movements are described by the following equations:

$$
\begin{gathered}
u=\exp _{d=1 / u} \sigma \overline{\Delta \mathrm{t}} \\
d=1 / u
\end{gathered}
$$

where $\sigma$ denotes annual volatility, and $\Delta \mathrm{t} \equiv 1 / 250$ denotes a single day in which prices can move up $u$ or down $d$, where the size of the down move is simply the reciprocal of the up move.

The probabilities of the moves are calculated using a modified version of the Cox et al. (1979) discretization scheme, in which the risk-neutral drift rate is replaced by the stock's expected return:

$$
\text { Prob } u_{i}=\frac{\exp r_{i} / 250-d_{i}}{u_{i}-d_{i}}
$$

This enables the design of a procedure that starts by generating correlated multivariate random variables, and then maps those variables into a simpler Bernoulli distribution. The binomial process for fundamental value fits comfortably with the sequential trade model of Section 3, whichwhen iterated over many time periods - recaptures the statistical properties of the original distribution.

\section{Multivariate Bernoulli Transformation}

The square matrix $\mathbf{C}$ can be expressed in terms of its diagonal eigenvalue matrix $\boldsymbol{\Lambda}$, and the corresponding unit-length eigenvector matrix $\mathbf{S}$ :

$$
C S=S \Lambda
$$

Provided the matrix $\mathbf{C}$ has only non-negative eigenvalues, Equation 3 can be post-multiplied throughout by the inverse matrix $\mathbf{S}^{-1}$ to yield

$$
C=S \Lambda S^{-1}
$$

Furthermore, since the eigenvector matrix has been defined in terms of unit-length vectors, Equation 4 may be written as

$$
C=S \Lambda S^{T}
$$

with $\mathbf{S}^{\mathbf{T}}$ replacing $\mathbf{S}^{\mathbf{- 1}}$. Now define $\mathbf{B}=\mathbf{S} \overline{\boldsymbol{\Lambda}}$. Then Equation 5 may be rewritten as

$$
C=S \bar{\Lambda} \bar{\Lambda} S^{T}=B B^{T},
$$

the spectral decomposition of the correlation matrix. A matrix of correlated standard normal random variables $\mathbf{X}$ is constructed using the transformation

$$
X=B Z
$$

where $\mathbf{Z}$ is a matrix of independent standard normal random variables.

Our objective is to use a simple mapping from the matrix $\mathbf{X}$ of correlated normal random variables into a matrix $\mathbf{P}$ of correlated Bernoulli random variables, which in turn are used in the binomial branching structure of the Glosten and Milgrom (1985) sequential trade model. We denote the multivariate Bernoulli distribution's marginal probabilities by $\pi_{1}, \pi_{2}, \ldots, \pi_{n}$. These probabilities correspond to each asset's probability of an up move, as defined by Equation 2. If a stock's characteristics are such that it has a high expected rate of return, then its probability of an up move 
will be higher - the magnitude of the move is given by Equation 1.

The resulting correlation matrix of returns has pairwise correlation coefficients that are significantly lower than the original correlation matrix C. The problem is overcome by first increasing the off-diagonal elements of $\mathbf{C}$ using the procedure proposed in Einrich and Piedmonte (1991). First, the quantiles of the standard normal distribution are evaluated at the Bernoulli marginal probabilities:

$$
z_{\pi_{i}}=z\left(\pi_{i}\right)
$$

Then, the pairwise correlation coefficients of C above the main diagonal are replaced by numerically solving for $u_{i, j}$ in the following equation:

$$
\rho_{i, j} \frac{\Phi_{2} z_{\pi_{i}}, z_{\pi_{j}} ; r_{i, j}=}{\pi_{i} 1-\pi_{i} \pi_{j} 1-\pi_{j} 1-\pi_{j}}+\pi_{i} \pi_{j},
$$

where $\phi_{2} \cdot$ is the c.d.f. of the bivariate standard normal distribution. The correlation coefficients below the main diagonal are set as $\rho_{\mathrm{i}, \mathrm{i}}=\rho_{\mathrm{i}, \mathrm{j}}$, ensuring that the new 'boosted' correlation matrix $\mathbf{C}^{\prime}$ is square-symmetric.

Using Equations 3 through 6, spectral decomposition is performed on C. However, it is well known (especially for larger portfolios) that the correlation matrix is likely to have at least one negative eigenvalue, making it impossible to invert the correlation matrix in the first step of the decomposition. One method of addressing this problem is to follow Rebonato and Jackel (1999) in setting any negative eigenvalues to zero, and then reconstructing a new correlation matrix as an approximation to the original. The eigenvector matrix $\mathbf{S}$ is post multiplied by the square-root of the corrected eigenvalue matrix $\Lambda^{/}$to yield the adjusted factor matrix

$$
B=\bar{T} S \overline{\Lambda^{\prime}},
$$

where $\mathbf{T}$ is a diagonal scaling matrix with elements $t_{i}={ }_{j=1}^{n} s_{i, j} \lambda_{j}$, i.e., the row-wise eigenvectors multiplied by the adjusted eigenvalues. The adjusted correlation matrix $\mathbf{C}^{\prime \prime}$ is defined by

$$
C^{\prime \prime}=B B^{T} \text {. }
$$

Finally, the boosted matrix of correlated standard normal random variables $\mathbf{X}^{\prime}=\mathbf{B}^{\prime} \mathbf{Z}$ is mapped into a matrix of correlated Bernoulli random variables $\mathbf{P}$ using the rule

$$
\begin{aligned}
p_{i i} & =1 & & \text { if } x_{i i} \leq z_{\pi_{i}} \\
& =0 & & \text { otherwise. }
\end{aligned}
$$

To summarize: we randomly create a target correlation matrix $\mathbf{C}$ that describes the original multivariate distribution of fundamental returns. The pairwise correlation coefficients of $\mathbf{C}$ are boosted in order to construct a new matrix $\mathbf{C}^{\prime}$ to be used in the generation of multivariate Bernoulli random variables. If the eigenvalues of $\mathbf{C}^{\prime}$ are all non-negative, then spectral decomposition is performed on $\mathbf{C}^{\prime}$; otherwise, a new correlation matrix $\mathbf{C}^{\prime \prime}$ is constructed from the 'corrected' diagonal matrix of eigenvalues. The adjusted matrix of correlated standard normal random variables is then mapped into a matrix of correlated Bernoulli random variables, which when used in conjunction with Equations 1 and 2 recovers the properties of the original correlation matrix $\mathbf{C}$.

\section{Intra-day Trading}

The intra-day model is based on Glosten and Milgrom $(1985)^{1}$, and is used to generate time series of opening and closing prices, with a view to testing various portfolio strategies. Opening prices are used to revalue current positions, and to determine the prices at which fresh purchases and sales are transacted; the opening bid-offer spread determines transaction costs. Closing prices are prices at which it is not possible to trade, but are commonly the ones used to calculate the returns to a strategy. They also play a central role in the volatility timing strategy, as the strategy uses volatility estimates calculated from rolling windows of closing prices. Closing prices are determined by the set of dealer quotes after the final trade of the day. The price discovery mechanism is expected to function better in high-volume conditions, with aggregate order imbalances reflecting asymmetric information.

There are four market participants: informed traders, uninformed traders, portfolio managers, and risk-neutral dealers. Price competition between dealers ensures that each dealer exactly offsets the expected losses from trading with informed traders with the expected gains from trading with uninformed traders. Provided the details of individual trades are made available to all dealers, the problem reduces analytically to that of one dealer.

Trading volume $\lambda$ determines the number of trades that take place each day. The sequential trade model deals with daily trading volume as a sequence of single-unit transactions between individual traders and the dealer. Traders are randomly selected, one at a time, from a large pool

${ }^{1}$ Other references include Easley and O'Hara (1992), who extend the model to include the possibility of infrequent information asymmetry, and Back and Baruch (2004). 
of informed and uninformed traders, with $q$ denoting the probability of drawing an informed trader. The dealer quotes an ask price at which traders may buy a single unit of the asset, and a bid price at which they may sell. When presented with these quotes, traders have the option to buy, sell, or pass on the trading opportunity. The dealer knows that informed traders will choose to buy only if Ask $<V_{t}$ (ask is below fundamental value), and will choose to sell only if $\mathrm{Bid}>V_{t}$ (bid is above fundamental value). Uninformed traders choose to trade for reasons unrelated to private information. They are, for example, motivated by hedging requirements, or by the need to meet liabilities. We assume that, for all quotes, uninformed traders randomly buy or sell with probability $1 / 2$.

In the basic version of the model, the dealer learns the true value of the asset at the end of each trading period. In the meantime, his ability to keep track of value depends on liquidity (the number of trades each period), and the proportion $q$ of informed traders.

Figure 1 illustrates the unconditional probabilities of various events, each organized by the trading decisions of informed and uninformed traders - and two possible changes in value.

We assume that the dealer is fully conversant with the structure of the model, and that his specialist knowledge ensures that he uses correct values for volatility and expected returns.

As a consequence, he correctly calculates the unconditional probabilities $p$ and $1-p$ of up and down moves. Informed traders never pass, because the presence of uniformed traders $((1-q)>0)$ ensures that if the next trader buys, expected value must lie below the 'up' value $V^{1}$. This is because the buy trade could come from an uninformed trader in the 'down' value state of the world. Similarly, if the next trader sells, expected value must lie above the 'down' value $V^{2}$.

The asset price is initially set to fundamental value $V^{0}$, and the returns generating process determines whether value moves up to $V^{1}$ or down to $V^{2}$. A trader is chosen at random from the pool of informed and uninformed traders, with $q$ denoting the probability of selecting an informed trader, and $1-q$ the probability of selecting an uninformed trader. Informed traders immediately receive a signal of the new value. The dealer's riskneutrality, and the zero-profit condition, leads the dealer to set his quotes according to

$$
\text { Ask }=\mathrm{E}[V \mid \text { next trader buys }
$$

And

$$
\mathrm{Bid}=\mathrm{E}[V \mid \text { next trader sells }] .
$$

The ask is set such that the dealer expects to make zero profit if the next trade is a buy. Because of the presence of uninformed traders, buy trades can occur for both values of $V$. Equation 9 therefore expands to

Ask $=V^{1} \operatorname{Prob} V^{1}$ buy $+V^{2} \operatorname{Prob}\left\{V^{2} \mid\right.$ buy $\}$

where Prob $V^{1}$ buy and $\operatorname{Prob}\left\{V^{2} \mid\right.$ buy $\}$ serve as the dealer's updating equations in a dynamic setting. Using Bayes' Rule, we obtain

$$
\text { Prob } V^{1} \text { buy }=\frac{\text { Prob buy } V^{1} \text { Prob } V^{1}}{\operatorname{Prob}\{\text { buy }\}}
$$

And

Prob $V^{2}$ buy $=\frac{\text { Prob buy } V^{2} \text { Prob } V^{2}}{\operatorname{Prob}\{\text { buy }\}}$.

Using the probabilities in the rightmost column of Figure 1,

Prob $V^{1}$ buy $=\frac{\pi_{1}(1+q)}{\pi_{1} 1+q+\pi_{2} 1-q}$

And

Prob $V^{2}$ buy $=\frac{\pi_{2}(1-q)}{\pi_{1} 1+q+\pi_{2} 1-q}$

The bid price is derived in a similar manner. Using the probabilities in the rightmost column of Figure 1,

$$
\text { Prob } V^{1} \text { sell }=\frac{\pi_{1}(1-q)}{\pi_{1} 1-q+\pi_{2} 1+q}
$$

and

$$
\text { Prob } V^{2} \text { sell }=\frac{\pi_{2}(1+q)}{\pi_{1} 1-q+\pi_{2} 1+q}
$$

Trading volume determines the quantity of random draws from the trading population in each session. The dealer updates his bid-ask spread using the updating Equations 9 and

10. After the final trade of the day, the midprice of the bid and ask prices is used as the closing price of the day. With a small probability $\zeta=0.1$, trading volume may change from a low-volume regime to a high-volume regime, and vice versa. The fundamental value becomes common knowledge in the time between the close of the current session and the open of the next. The dealer's opening spread reflects this update in public information. 
Figure 1. Probability of different types in the sequential trade model

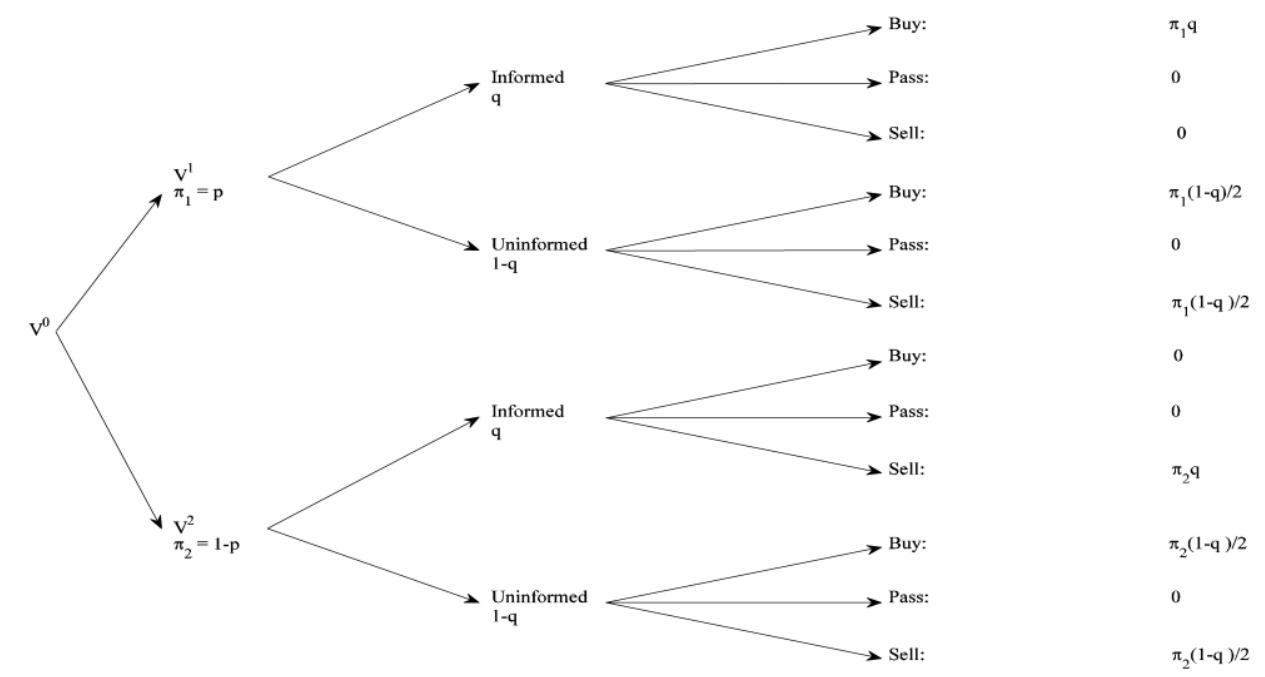

\section{Portfolio Strategies}

We consider two portfolio strategies: naive diversification and volatility timing. Both strategies are fully-invested, and exclude the possibility of short sales. The naive diversification strategy allocates a weight of

$$
w_{j}=1 / n, \quad j=1, \ldots, n
$$

to each portfolio constituent, whereas the volatility timing strategy allocates capital on the basis of a modified version of the minimum variance portfolio.

The problem set-up for the volatility timing strategy is

$$
\min _{\mathbf{w} \geq \mathbf{0}} \mathbf{w}^{\prime} \mathbf{V w}
$$

subject to

$$
{ }_{j=1}^{n} w_{j}=1
$$

where $\mathbf{w}$ is the vector of portfolio weights, and $\mathbf{V}$ is the variance-covariance matrix of returns. It can be shown that the solution to the problem is

$$
w_{j}=\frac{\psi_{j}}{\sum_{i=1}^{n} \psi_{j}=1},
$$

where $\psi_{j}$ is the sum of the elements of the $j$ th column of $\mathbf{V}^{-1}$, the inverse of $\mathbf{V}$. However, the volatility timing strategy removes the need to compute the inverse by setting the off-diagonal elements $\mathbf{V}$ of to zero. The elements of the inverse matrix are now simply the reciprocal of the elements of the original matrix, and the solution to the problem is

$$
w_{j}=\frac{1 / \sigma_{j}^{2}}{n_{i=1}^{n} \sigma_{i}^{2}},
$$

where $\sigma_{j}^{2}$ is the variance of the returns to asset $j$. As with the naive diversification portfolio, the weights of the volatility timing portfolio are nonnegative. Both strategies are fully-invested, and both strategies attempt to reduce the high turnover and estimation errors associated with full meanvariance optimization.

We adopt the simplifying assumption that the trades made by portfolio managers do not influence the intra-day dynamics of price. ${ }^{2}$ Instead, we assume that orders are good for any size at the opening bid-ask spread, and that portfolio managers place all their orders at the open. This has the additional analytical advantage of separating the influence of private information on transaction costs from its influence (in combination with trading volume) on 'price discovery'. The closing price is used to value positions at the end of each day, which in turn allows calculation of the daily returns to each strategy. Closing prices also provide the information that the volatility timing strategy uses for calculating rolling estimates of daily volatilities - the estimates that in turn determine the desired weights in each asset for the next session. The following algorithms describe the daily activities of the naive diversification and volatility timing strategies.

\footnotetext{
${ }^{2}$ An interesting enhancement would be to include portfolio managers as part of the trading population, with their orders contributing to daily trading volume-and hence price dynamics. However, the order-splitting strategy of managers needs to be carefully addressed in such a setting.
} 


\section{Algorithm 1: Naive Diversification}

\section{Step 1: Revalue account using opening mid-prices}

Positions $q_{j}$ are revalued at the dealer's opening mid-price $p_{j}$ :

$$
\text { account }=\prod_{j=1}^{n} q_{j} p_{j}+c,
$$

where $c$ is the value of short-term cash balances. We allow small temporary negative cash positions, but do not allow strategies to manage leverage strategically.

\section{Step 2: Calculate Desired Positions}

The account size is multiplied by $1 / n$, and divided by the dealer's opening mid-price to yield a new desired holding $q_{j}$ :

$$
q_{j}=\frac{\text { account } \times 1 / n}{p_{j}} \quad j=1, \ldots, n
$$

\section{Step 3: Calculate Orders}

New orders are calculated as the difference between desired positions $q_{j}$ and current positions $q_{j}$ :

$$
o_{j}=q_{j}-q_{j}, \quad j=1, \ldots, n .
$$

where $o_{j}$ denotes today's order in asset $j$.

\section{Step 4: Calculate Expenditure and Income}

For buy orders, expenditure is calculated using the dealer's ask price, and for sell orders, income is calculated using the bid price:

$$
c_{j}=\begin{array}{cc}
o_{j} \times \operatorname{Ask}_{j} & \text { if } o_{j}>0 \\
o_{j} \times \operatorname{Bid}_{j} & \text { if } o_{j}<0
\end{array}
$$

The change in the cash position is the sum of expenditure and income over all assets:

$$
\Delta \mathrm{c}={ }_{j=1}^{n} c_{j}
$$

\section{Step 5: Revalue Account at Closing Mid-Prices}

At the conclusion of intra-day trading, the final dealer quotes are used to calculate closing pricesthe final mid-prices for each asset. The account is re-valued, and the daily return to the naive diversification strategy is calculated using

$$
r_{t}=\operatorname{account}_{t} / \text { account }_{t-1}-1 \text {. }
$$

\section{Algorithm 2: Volatility Timing}

Step 1: Revalue account using opening mid-prices

Positions $q_{j}$ are revalued at the dealer's opening mid-price $p_{j}$ :

$$
\text { account }=\prod_{j=1}^{n} q_{j} p_{j}+c,
$$

where $c$ is the value of any cash holdings.

\section{Step 2: Calculate Desired Positions}

The account size is multiplied by the weights calculated in Equation 16, and divided by the dealer's opening mid-price to yield a new desired holding $q_{j}$ :

$$
q_{j}=\operatorname{account} \times \frac{1 / \sigma_{j}^{2}}{\sum_{i=1}^{n} \sigma_{i}^{2}} / p_{j} \quad j=1, \ldots, n
$$

\section{Step 3: Calculate Orders}

New orders are calculated as the difference between desired positions $q_{j}$ and current positions $q_{j}$ in each asset:

$$
o_{j}=q_{j}-q_{j}, \quad j=1, \ldots, n .
$$

where $o_{j}$ denotes today's order in asset $j$.

\section{Step 4: Calculate Expenditure and Income}

For buy orders, expenditure is calculated using the dealer's ask price, and for sell orders, income is calculated using the bid price:

$$
c_{j}=\begin{array}{cc}
o_{j} \times \mathrm{Ask}_{j} & \text { if } o_{j}>0 \\
o_{j} \times \operatorname{Bid}_{j} & \text { if } o_{j}<0
\end{array}
$$

The change in the cash position is the sum of expenditure and income over all assets:

$$
\Delta \mathrm{c}={ }_{j=1}^{n} c_{j}
$$

\section{Step 5: Revalue Account at Closing Mid-Prices}

At the conclusion of intra-day trading, the final dealer quotes are used to calculate closing pricesthe final mid-prices for each asset. The account is re-valued, and the daily return to the volatility timing strategy is calculated using

$$
r_{t}=\text { account }_{t} / \text { account }_{t-1}-1 \text {. }
$$


It now remains to examine large-sample returns and risk-adjusted returns to the two strategies for various market conditions. Each simulation generates 10 years of intra-day trade and closing prices. Each market condition is tested for 1000 simulations of fundamental values.

\section{Results}

Each cell of Table 2 contains the mean annual return and Sharpe ratio for 1000 multivariate simulations of fundamental values using the singleindex model of Section 2. The upper panel contains the results for 2 -stock portfolios. The middle panel contains the results for 5-stock portfolios, and the lower panel the results for 10-stock portfolios. Within each panel, the results are split horizontally into those results for the naive diversification strategy, and those for the volatility timing strategy. Vertically, the results are arranged by increasing levels of asymmetric information or probabilities of informed trade. Within each of these sections, an individual cell corresponds (vertically) to the level of trading volume in an illiquid state $(10,50$, or 250 ), and (horizontally) to a level of trading volume in a liquid state $(50,250,1000)$. For example, the upper-left cell of the top panel reports a mean return of $10.21 \%$, and a Sharpe ratio of 0.59 for the naive diversification strategy. This corresponds to 1000 underlying simulations of markets in which the probability of informed trade is 0.01 , trading volume in the illiquid state is 10 , and trading volume in the liquid state is 50. An alternative to the two-state model is a single-state model with constant volume, but we prefer to allow for the possibility of the price discovery mechanism being disrupted at the points where regime shifts occur. The probability of switching is $\zeta=0.1$, which is intended to reflect our intuition that markets 'remember' the current regime.

For the 2-stock portfolio, an interesting pattern develops as the level of asymmetric information increases from 0.01 through 0.20 . For the $(10,50)$ volume combination, the mean return for the naive diversification strategy is at its highest when $q=$
0.01. This is to be expected, as the dealer quotes narrow spreads when the probability of adverse selection is low. As the probability of informed trade rises from 0.01 to 0.05 , and from 0.05 to 0.10 , the naive diversification strategy's mean return falls to $9.85 \%$, and then to $9.31 \%$. The interesting change, however, occurs when the probability of informed trade rises from

0.10 to 0.20 : the mean return rises to $9.53 \%$, despite the dealer's wider spreads. A similar pattern occurs for the corresponding Sharpe ratio: 0.59, $0.58,0.56$, and then an increase to 0.60 . As this pattern disappears for portfolios with more assets, we suggest that the pattern is linked to the naive diversification strategy's in-built tendency to overallocate capital to high beta stocks.

The pattern for mean returns is broadly similar for the volatility timing strategy, with apparently little difference between the volatility timing and naive diversification strategies' mean returns under similar market conditions. The most striking difference, however, is in the levels of the Sharpe ratio-the volatility timing strategy consistently produces results approximately 0.20 in excess of those of the naive diversification strategy. In the illiquid volume combination $(10,50)$, the highest Sharpe ratio of the volatility timing strategy $(0.81)$ occurs when the level of asymmetric information is at its highest. In the most liquid combination (250, $1000)$, the highest Sharpe ratio occurs when $q=$ 0.05 , and falls thereafter. The volatility timing strategy outperforms the naive diversification strategy, not because of its similar mean returns, but because of its lower risk. Efficient price discovery is essential to its success, with the presence of asymmetric information offsetting the impediment to price discovery inherent in low trading volume. That the volatility timing strategy consistently outperforms the naive diversification strategy confirms our view that those strategies that rely on accurate prices, and in turn returns, benefit most from a reasonable level of asymmetric information. In the next section we more formally identify the drivers of portfolio performance.

Table 2. Mean Returns and Sharpe Ratios

\begin{tabular}{|c|c|c|c|c|c|c|c|c|c|c|c|c|c|}
\hline \multicolumn{14}{|c|}{ 2-Stock Portfolio } \\
\hline & & \multicolumn{6}{|c|}{ Naive Diversification } & \multicolumn{6}{|c|}{ Volatility Timing } \\
\hline & & \multicolumn{2}{|c|}{$\mathbf{5 0}$} & \multicolumn{2}{|c|}{250} & \multicolumn{2}{|c|}{1000} & \multicolumn{2}{|c|}{$\mathbf{5 0}$} & \multicolumn{2}{|c|}{250} & \multicolumn{2}{|c|}{1000} \\
\hline & 10 & 10.21 & 0.59 & 9.77 & 0.58 & 9.52 & 0.55 & 10.17 & 0.80 & 9.83 & 0.79 & 9.50 & 0.74 \\
\hline \multirow[t]{3}{*}{$q=0.01$} & $\mathbf{5 0}$ & & & 10.01 & 0.60 & 9.96 & 0.59 & & & 10.01 & 0.80 & 9.90 & 0.78 \\
\hline & 250 & & & & & 10.03 & 0.59 & & & & & 10.01 & 0.80 \\
\hline & $\mathbf{1 0}$ & 9.85 & 0.58 & 9.70 & 0.55 & 9.18 & 0.58 & 9.94 & 0.77 & 9.69 & 0.78 & 9.31 & 0.79 \\
\hline \multirow[t]{3}{*}{$q=0.05$} & 50 & & & 9.44 & 0.58 & 10.10 & 0.63 & & & 9.53 & 0.79 & 10.19 & 0.85 \\
\hline & 250 & & & & & 9.80 & 0.61 & & & & & 9.88 & 0.82 \\
\hline & 10 & 9.31 & 0.56 & 9.06 & 0.55 & 9.31 & 0.59 & 9.47 & 0.76 & 9.13 & 0.75 & 9.58 & 0.82 \\
\hline \multirow[t]{3}{*}{$q=0.10$} & 50 & & & 9.34 & 0.58 & 9.48 & 0.60 & & & 9.54 & 0.80 & 9.42 & 0.80 \\
\hline & 250 & & & & & 10.03 & 0.60 & & & & & 9.96 & 0.81 \\
\hline & 10 & 9.53 & 0.60 & 9.13 & 0.56 & 9.35 & 0.59 & 9.59 & 0.81 & 9.29 & 0.76 & 9.47 & 0.81 \\
\hline \multirow[t]{2}{*}{$q=0.20$} & 50 & & & 9.50 & 0.57 & 9.38 & 0.57 & & & 9.61 & 0.77 & 9.56 & 0.77 \\
\hline & 250 & & & & & 9.74 & 0.59 & & & & & 9.76 & 0.80 \\
\hline
\end{tabular}




\begin{tabular}{|c|c|c|c|c|c|c|c|c|c|c|c|c|c|}
\hline & & \multicolumn{6}{|c|}{$\begin{array}{l}\text { 5-Stock Portfoli } \\
\text { Naïve Diversification }\end{array}$} & \multicolumn{6}{|c|}{ Volatility Timing } \\
\hline & & \multicolumn{2}{|c|}{50} & \multicolumn{2}{|c|}{250} & \multicolumn{2}{|c|}{1000} & \multicolumn{2}{|c|}{50} & \multicolumn{2}{|c|}{250} & \multicolumn{2}{|c|}{1000} \\
\hline$q=0.01$ & $\begin{array}{c}10 \\
50 \\
250\end{array}$ & 10.03 & 0.63 & $\begin{array}{c}9.90 \\
10.21\end{array}$ & $\begin{array}{l}0.64 \\
0.64\end{array}$ & $\begin{array}{l}9.93 \\
9.70 \\
9.82\end{array}$ & $\begin{array}{l}0.64 \\
0.63 \\
0.65\end{array}$ & 9.92 & 1.01 & $\begin{array}{c}9.99 \\
10.16\end{array}$ & $\begin{array}{l}1.05 \\
1.03\end{array}$ & $\begin{array}{l}9.99 \\
9.97 \\
9.86\end{array}$ & $\begin{array}{l}1.06 \\
1.05 \\
1.06\end{array}$ \\
\hline$q=0.05$ & $\begin{array}{c}10 \\
50 \\
250\end{array}$ & 9.69 & 0.63 & $\begin{array}{l}9.54 \\
9.46\end{array}$ & $\begin{array}{l}0.67 \\
0.68\end{array}$ & $\begin{array}{l}9.21 \\
9.15 \\
9.15\end{array}$ & $\begin{array}{l}0.69 \\
0.69 \\
0.68\end{array}$ & 9.75 & 1.04 & $\begin{array}{l}9.88 \\
9.68\end{array}$ & $\begin{array}{l}1.12 \\
1.12\end{array}$ & $\begin{array}{l}9.62 \\
9.55 \\
9.62\end{array}$ & $\begin{array}{l}1.17 \\
1.17 \\
1.16\end{array}$ \\
\hline$q=\mathbf{0 . 1 0}$ & $\begin{array}{c}10 \\
50 \\
250\end{array}$ & 9.17 & 0.65 & $\begin{array}{l}9.20 \\
8.84\end{array}$ & $\begin{array}{l}0.69 \\
0.66\end{array}$ & $\begin{array}{l}9.29 \\
9.20 \\
9.22\end{array}$ & $\begin{array}{l}0.70 \\
0.68 \\
0.60\end{array}$ & 9.45 & 1.09 & $\begin{array}{l}9.49 \\
9.36\end{array}$ & $\begin{array}{l}1.18 \\
1.10\end{array}$ & $\begin{array}{l}9.53 \\
9.53 \\
9.48\end{array}$ & $\begin{array}{l}1.15 \\
1.14 \\
1.01\end{array}$ \\
\hline \multirow[t]{2}{*}{$q=0.20$} & $\begin{array}{c}10 \\
50 \\
250 \\
\end{array}$ & 8.71 & 0.66 & $\begin{array}{l}9.08 \\
9.07\end{array}$ & $\begin{array}{l}0.66 \\
0.61\end{array}$ & $\begin{array}{l}8.87 \\
9.30 \\
9.33 \\
\end{array}$ & $\begin{array}{l}0.65 \\
0.64 \\
0.59\end{array}$ & 9.15 & 1.12 & $\begin{array}{l}9.48 \\
9.54\end{array}$ & $\begin{array}{l}1.11 \\
1.04\end{array}$ & $\begin{array}{l}9.30 \\
9.67 \\
9.54 \\
\end{array}$ & $\begin{array}{l}1.10 \\
1.07 \\
0.99 \\
\end{array}$ \\
\hline & & \multicolumn{11}{|c|}{ 10-Stock Portfolio } & Volatility Timing \\
\hline$q=0.01$ & $\begin{array}{c}10 \\
50 \\
250\end{array}$ & 9.87 & 0.69 & $\begin{array}{l}9.75 \\
9.77\end{array}$ & $\begin{array}{l}0.68 \\
0.69\end{array}$ & $\begin{array}{l}9.89 \\
9.62 \\
9.57\end{array}$ & $\begin{array}{l}0.70 \\
0.69 \\
0.70\end{array}$ & 9.90 & 1.21 & $\begin{array}{l}9.90 \\
9.82\end{array}$ & $\begin{array}{l}1.22 \\
1.20\end{array}$ & $\begin{array}{l}9.98 \\
9.77 \\
9.75\end{array}$ & $\begin{array}{l}1.23 \\
1.21 \\
1.23\end{array}$ \\
\hline$q=0.05$ & $\begin{array}{c}10 \\
50 \\
250\end{array}$ & 9.59 & 0.70 & $\begin{array}{l}9.55 \\
9.59\end{array}$ & $\begin{array}{l}0.76 \\
0.79\end{array}$ & $\begin{array}{l}9.31 \\
9.38 \\
9.36\end{array}$ & $\begin{array}{l}0.80 \\
0.82 \\
0.81\end{array}$ & 9.85 & 1.26 & $\begin{array}{l}9.81 \\
9.86\end{array}$ & $\begin{array}{l}1.35 \\
1.40\end{array}$ & $\begin{array}{l}9.74 \\
9.79 \\
9.72\end{array}$ & $\begin{array}{l}1.46 \\
1.48 \\
1.44\end{array}$ \\
\hline$q=0.10$ & $\begin{array}{c}10 \\
50 \\
250\end{array}$ & 9.25 & 0.74 & $\begin{array}{l}9.15 \\
9.23\end{array}$ & $\begin{array}{l}0.80 \\
0.79\end{array}$ & $\begin{array}{l}9.20 \\
8.97 \\
9.38\end{array}$ & $\begin{array}{l}0.80 \\
0.76 \\
0.69\end{array}$ & 9.62 & 1.34 & $\begin{array}{l}9.59 \\
9.67\end{array}$ & $\begin{array}{l}1.45 \\
1.43\end{array}$ & $\begin{array}{l}9.66 \\
9.55 \\
9.72\end{array}$ & $\begin{array}{l}1.46 \\
1.42 \\
1.23\end{array}$ \\
\hline$q=\mathbf{0 . 2 0}$ & $\begin{array}{c}10 \\
50 \\
250\end{array}$ & 8.69 & 0.76 & $\begin{array}{l}8.71 \\
9.13\end{array}$ & $\begin{array}{l}0.73 \\
0.69\end{array}$ & $\begin{array}{l}8.57 \\
8.97 \\
9.00\end{array}$ & $\begin{array}{l}0.73 \\
0.68 \\
0.62\end{array}$ & 9.44 & 1.42 & $\begin{array}{l}9.37 \\
9.60\end{array}$ & $\begin{array}{l}1.38 \\
1.27\end{array}$ & $\begin{array}{l}9.38 \\
9.56 \\
9.51\end{array}$ & $\begin{array}{l}1.39 \\
1.25 \\
1.14\end{array}$ \\
\hline
\end{tabular}

\subsection{Data Visualization and Interpretation}

Table 2 presents our results in finely-classified samples. While it is clear from the table that the Sharpe ratios of the volatility timing strategy dominate those of the naïve diversification strategy, it is not easy to determine whether strategy type, or some other characteristic of market conditions, is the key driver of portfolio performance. For instance, the probability of informed trade may be important, as may be the simple diversification effect from increasing the number of portfolio constituents. Classification trees, a technique from the nonparametric statistics literature, offer an excellent way of ranking the determinants of portfolio performance, as well as providing a neat visual representation of the data. They are ideally suited to a ranking task, with the data being repeatedly partitioned according to those elements of the sample space that most reduce prediction error. The key reference is Breiman et al. (1984). ${ }^{3}$

The response variable $\mathbf{Y}$ is predicted using a multivariate set of predictors $\mathbf{X}$. In this paper, we consider two response variables - the mean return

${ }^{3}$ Software-based tutorials include Martinez and Martinez (2008) and Torgo (2011). and the Sharpe ratio of a strategy. The set of predictors includes the strategy type, the number of stocks in the portfolio, the probability of informed trade, and the volume of trade in the illiquid state.

Consider first the two trees for the mean prediction task. Figures 2 and 3 are in fact drawn from one tree, but have been separated to improve legibility. Each sample of observations is represented by an ellipsis or rectangle. The ellipses represent samples that will be divided further into smaller groups; the rectangles, known as the 'leaves' or 'terminal nodes' of the tree, represent the finest partitions of the data. Theoretically, the samples can be partitioned into ever-decreasing samples, until each terminal node contains only one observation, but in practice a tree ceases to be grown (or is 'pruned') according to a statistical or normative criterion. With a view to clarity and parsimony, we terminate the trees using a maximum depth criterion: the number of levels below the initial sample is set to 5 , meaning that each of the sub-figures, Figure 2 and Figure 3, has 4 levels. When compared with alternative statistical pruning procedures, we find that this level of detail errs on the side of parsimony-further nodes, by definition, improve the in-sample predictive accuracy of the tree, but do so with increased risk of over-fitting. 
There are 144,000 observations in the full sample, which correspond to the 144 cells of Table 2. The pooled mean return is $9.55 \%$ for these observations. The procedure examines all possible partitions across the predictor variables, and chooses the best binary split- defined as the partition that most reduces the total mean-squarederror of the tree.

Formally, the mean of the full sample is defined by

$$
y=\frac{1}{n} y_{i}
$$

and the mean-squared-error by

$$
R=y_{i}-y^{2} \text {. }
$$

After the first split, there are two nodes, each with its own $y$ and $R$. Denote these within-node squared errors by $R_{1}$ and $R_{2}$. After the first split, the mean-squared-error of the tree is the sum of $R_{1}$ and $R_{2}$.

The first partition of the mean returns classification tree splits the full sample into two groups. The first contains observations in which the probability of informed trade $q \in\{0.01,0.05\}$, and the second contains observations in which $q \in$ $\{0.10,0.20\}$. These are the nodes at the top of the trees of Figures 2 and 3. Interpreting these two new samples as 'low' and 'high' asymmetric information samples, the low asymmetric information tree of Figure 2 has a sample mean of $9.76 \%$, with 72,000 observations. The high asymmetric information tree also contains 72,000 observation, but with a mean return of $9.35 \%$. The $0.41 \%$ fall in mean returns represents a flow of wealth from uninformed to informed traders.

We next consider the low asymmetric information and high asymmetric information trees. For each tree, we describe a particular path down the tree. The highest mean return of Figure 2 is $9.97 \%$, represented by the second terminal node from the left. The first partition of the tree divides observations into probabilities of informed trade of $q=0.01$ and $q=0.05$. In markets with the lowest probability of informed trade $(q=0.01)$, mean returns are $9.89 \%, 0.27 \%$ higher than the mean returns generated by markets with $q=0.05$. Continuing down the $q=0.01$ branch of the tree, the next most important driver of performance is the number of portfolio constituents, with those portfolios containing 2 or 5 stocks generating higher returns than those with 10 stocks. An explanation for this phenomenon could be that the naive diversification strategy allocates equal levels of capital to high-volatility and low-volatility assets, thus boosting mean returns when the number of portfolio constituents is small. More clearly, in the next partition, mean returns are higher when trading volume is high in the illiquid state. Note that this path down the tree does not distinguish the returns to the naive diversification strategy from those to the volatility timing strategy. The story is different, however, in the high asymmetric information tree.

Figure 3 demonstrates that, conditional on the probability of informed trade being $10 \%$ or $20 \%$, the next partition that most reduces the tree's meansquared-error is strategy type. The returns to the naive diversification strategy are $9.18 \%$, whereas they are $9.52 \%$ for the volatility timing strategy. This would suggest that the naive diversification strategy generates a higher turnover of trade than does the volatility timing strategy - a feature that most impacts on performance when bid-ask spreads are wide. Continuing down the volatility timing strategy path, the next partition is according to the volume in the illiquid state, with volumes of 50 or 250 generating higher returns than a volume of 10 . The final partition, branching to the farthest-right terminal node $(9.66 \%$ across 6,000 observations), further distinguishes illiquid state trading volume of 50 from trading volume of 250 . In sum, in markets characterized by high levels of asymmetric information, a volatility timing strategy applied under conditions of high overall liquidity generates on average mean returns of $9.66 \%$ p.a.

We conclude this section by examining the classification tree in which the response variable is the Sharpe ratio of the volatility timing strategy (Figure 5). We describe the path that leads to the highest Sharpe ratios. The root node of Figure 5 contains 72,000 observations, with a mean Sharpe ratio of 1.07. The next partition is with respect to the number of portfolio constituents, with the Sharpe ratios of 5 or 10 stock portfolios, substantially exceeding those of 2-stock portfolios (1.21 versus 0.79 ). Of those portfolios with 5 or 10 stocks, the next partition distinguishes the 5-stock portfolios from the 10-stock portfolios. On average, 10-stock volatility timing portfolios generate Sharpe ratios of $1.33,0.24$ higher than 5-stock portfolios. It is interesting to note, however, that the terminal nodes across the tree are partitioned according to the probability of informed trade. For 2-stock portfolios there appears to be little difference between the average Sharpe ratios in each sample, with terminal nodes containing average Sharpe ratios of $0.78,0.79,0.81$, and 0.78 . However, for better-diversified portfolios, the optimal partition splits the observations by probabilities of informed trade of $1 \%$, and probabilities of informed trade of greater than $1 \%$. Even though higher levels of private information lead to wider spreads and higher transaction costs, they lead to higher Sharpe ratios for both the 5stock and 10-stock portfolios. This 'price discovery' effect is most pronounced in the 10stock portfolios, with an improvement in the Sharpe 
ratio from 1.21 to 1.37 when the probability of informed trade exceeds $1 \%$.

\section{Conclusions}

We develop a framework in which multi-asset fundamentals are mapped into binomial processes compatible with the Glosten and Milgrom (1985) sequential trade model. Intra-day price dynamics are generated by dealers' Bayesian updating equations, with closing prices determined by the average of the final bid and ask prices of each session. The degree to which closing prices track fundamental value is determined by the joint interaction between private information and trading volume. Higher levels of private information reduce mean returns, as dealers widen spreads to compensate for the losses incurred from informed trade. But private information also helps to improve the price discovery process, thus improving the risk-adjusted returns of strategies that rely on accurate volatility estimates.

We use nonparametric classification trees to identify and rank the determinants of portfolio performance. Mean returns are primarily driven by the probability of informed trade, whereas the strategy type - naive diversification or volatility timing - is the key driver of risk-adjusted returns. This suggests that the higher Sharpe ratios of the volatility timing strategy arise because of its objective of minimizing risk; this does not appear to sacrifice mean returns. The diversification effect from increasing the number of portfolio constituents is the next most important driver of risk-adjusted returns, with the highest Sharpe ratios of both strategies occurring in the 10-stock portfolios. We note the interesting dominance of the volatility timing Sharpe ratios in markets when the probability of informed trade is greater than $1 \%$. Indeed, looking down the columns of Table 2, it is evident that the lower mean returns associated with wider spreads are often accompanied by higher Sharpe ratios, there being an apparent 'optimal' level of asymmetric information, beyond which Sharpe ratios decline. These declines occur as higher levels of transaction costs begin to dominate improvements in the price discovery mechanism.

With regard to extensions and future research, we have deliberately designed the framework with flexibility in mind. We have used a single-index model, but envisage more elaborate factor models in the data generation stage. The recombining tree structure of our sequential trade model allows for stochastic news arrivals, whilst keeping the dealer's updating task manageable. We would maintain the informational advantage of the insiders during the 'no news' days, thus making a distinct contribution to the literature.

\section{References}

1. Breiman, L., Friedman, J., Olshen, R., Stone, C., 1984. Classification and regression trees. Wadsworth, Inc., New York.

2. Brunnermeier, M. K., 2001. Asset pricing under asymmetric information. Oxford University Press, Oxford.

3. Cox, J. C., Ross, S. A., Rubinstein, M., 1979. Option pricing: a simplified approach.

4. Journal of Financial Economics 7, 229-263.

5. DeMiguel, V., Garlappi, L., Uppal, R., 2009. Optimal versus naive diversification: How inefficient is the $1 / \mathrm{n}$ portfolio strategy? Review of Financial Studies 22, 1915-1953.

6. Easley, D., O'Hara, M., 1987. Price, trade size, and information in securities markets. Journal of Financial Economics 19, 69-90.

7. Easley, D., O'Hara, M., 1992. Time and the process of security price adjustment. Journal of Finance 47, 577-605.

8. Einrich, L. J., Piedmonte, M. R., 1991. A method for generating high-dimensional multivariate binary variates. The American Statistician 45, 302-304.

9. Glosten, L., Milgrom, P., 1985. Bid, ask and transaction prices in a specialist market with heterogeneously informed traders. Journal of Financial Economics 14, 71-100.

10. Ho, T., Stoll, H. R., 1981. Optimal dealer pricing under transactions and return uncertainty. Journal of Financial Economics 9, 47-73.

11. Kirby, C., Ostdiek, B., 2012. It's all in the timing: Simple active portfolio strategies that outperform nave diversification. Journal of Financial and Quantitative Analysis 47 (02), 437-467.

12. Kyle, A., 1985. Continuous auctions and insider trading. Econometrica 53, 1315-1335.

13. Martinez, W. L., Martinez, A. R., 2008. Computational Statistics Handbook with MATLAB. Chapman \& Hall/CRC, Boca Raton,FL.

14. O'Hara, M., 1995. Market Microstructure Theory. Blackwell, Cambridge, MA.

15. Rebonato, R., Jackel, P., 1999. The most general methodology to create a valid correlation matrix for risk management and option pricing purposes. Quantitative Research Centre of the NatWest Group, $1-12$.

16. Torgo, L., 2011. Data mining with R: Learning with case studies. Chapman \& Hall/CRC, Boca Raton, FL. 
Corporate Ownership \&Z Control/Volume 11, Issue 1, Fall 2013

Figure 2. Mean Returns: $q \in\{0.01,0.05\}$
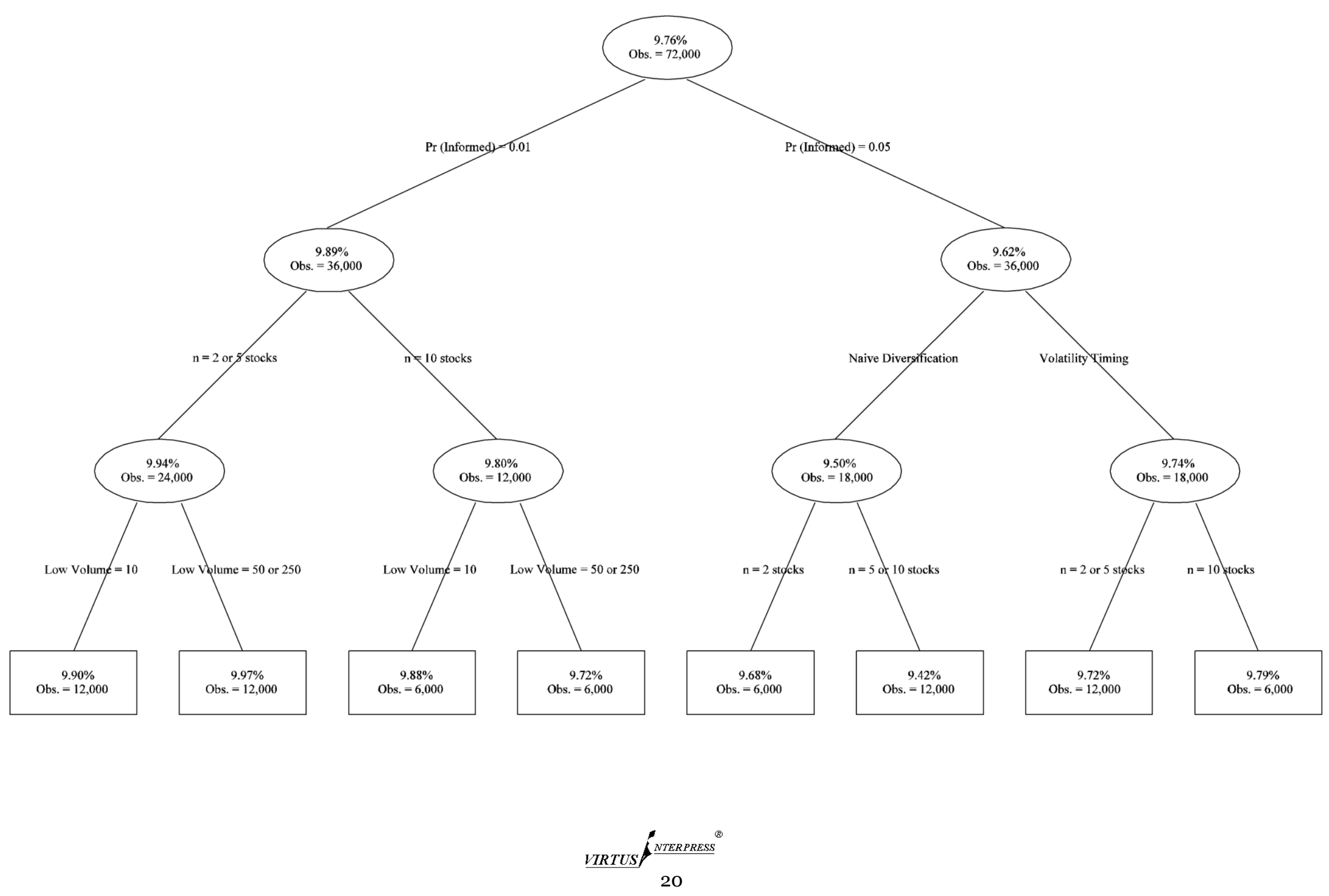
Figure 3. Mean Returns: $q \in\{0.10,0.20\}$

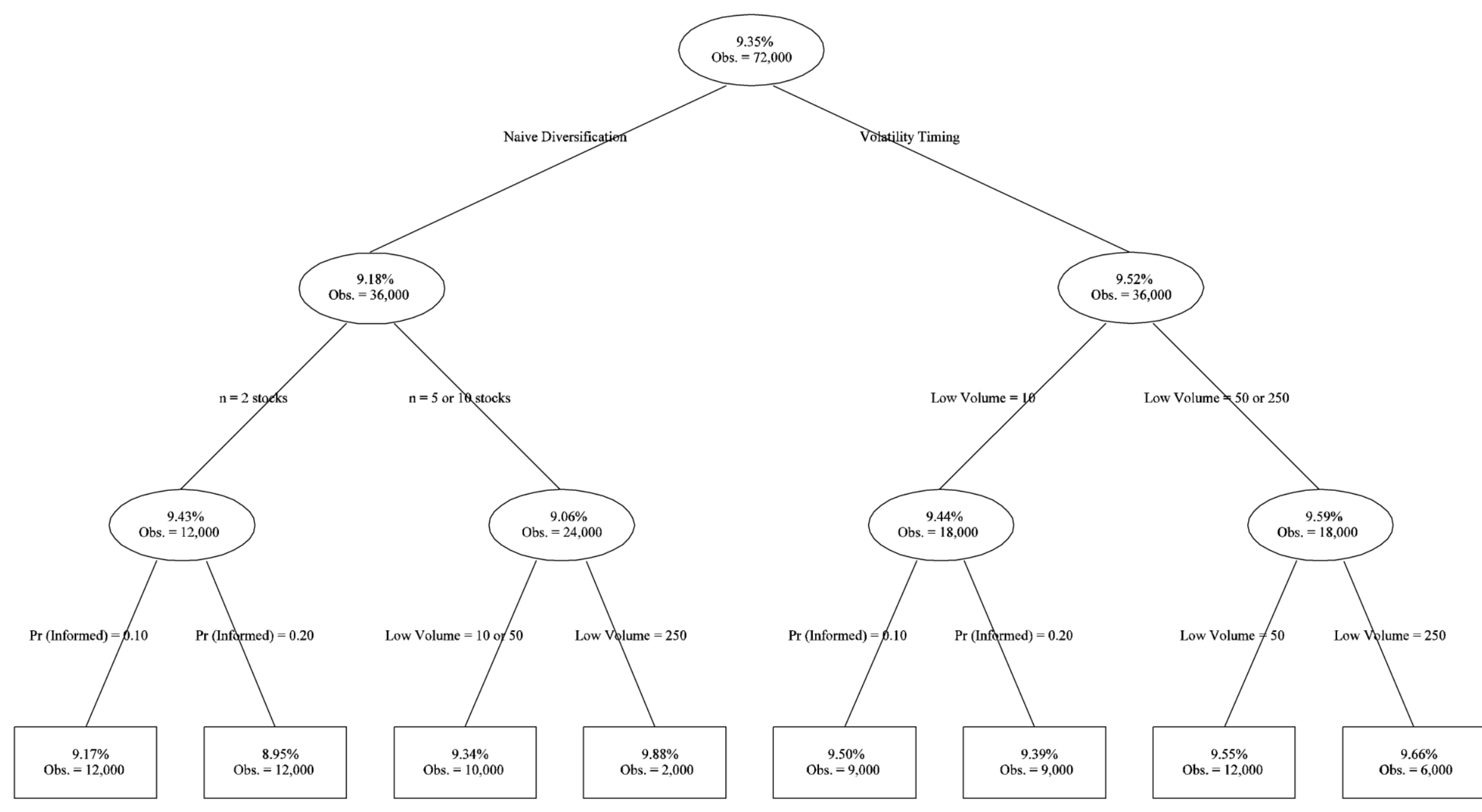

VIRTUS 
Figure 4. Sharpe Ratios: Naïve Diversification

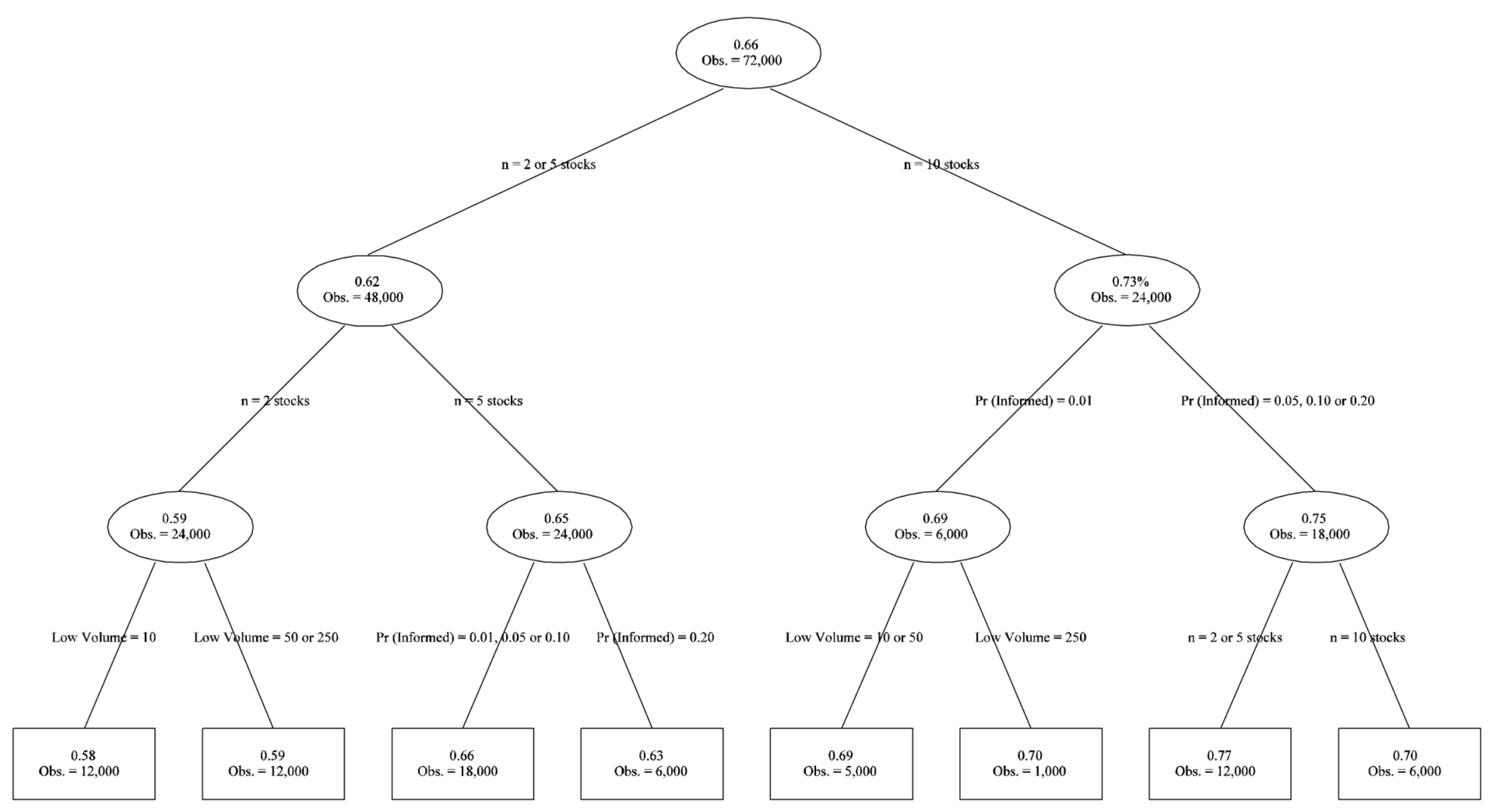

VIRTUS NTERPRESS 
Figure 5. Sharpe Ratios: Volatility Timing

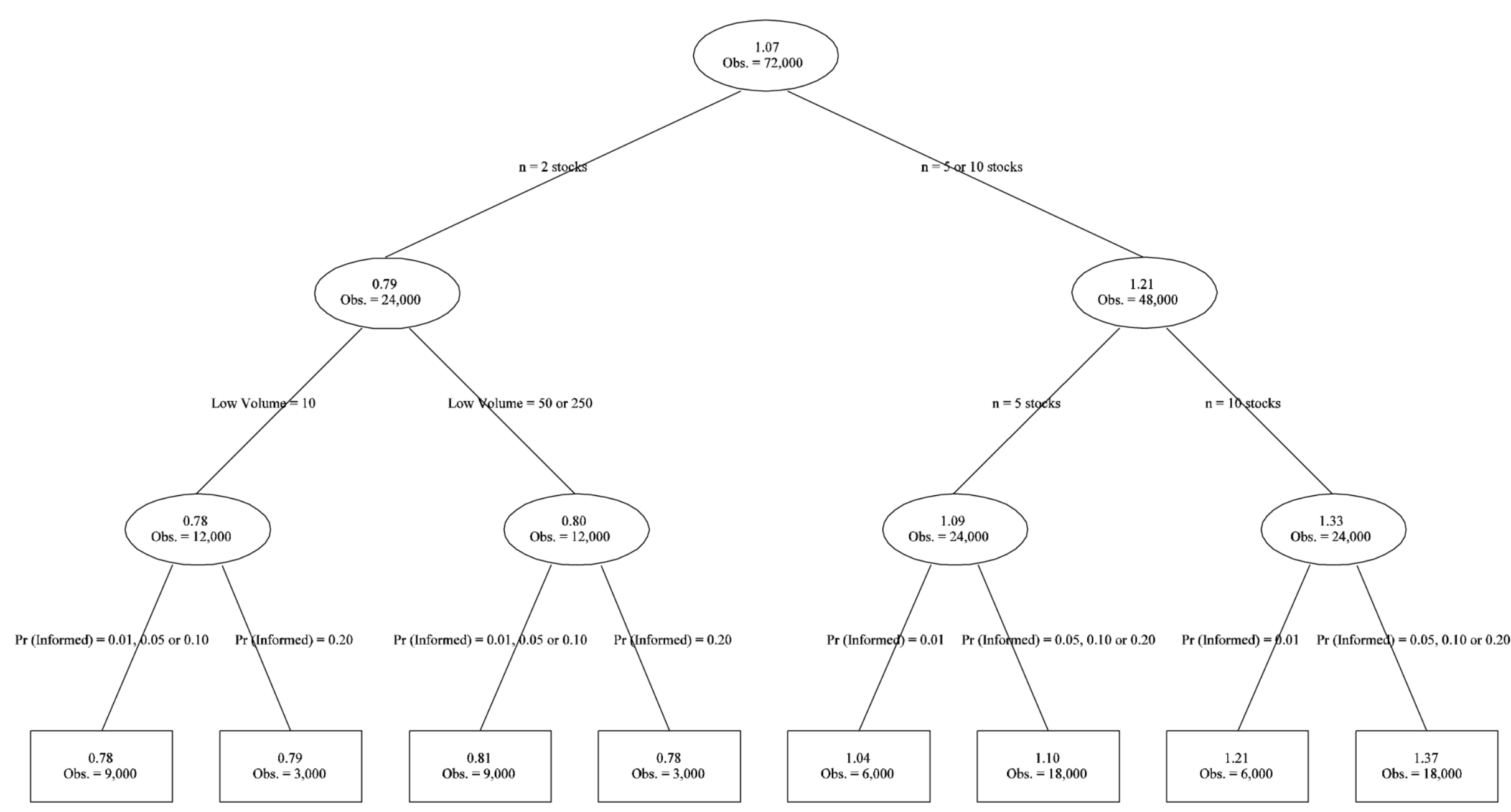

VIRTUS 


\title{
HOW TO CONTROL THE CONTROLLER - CEO COMPENSATION AND MOTIVATION
}

\author{
Udo C. Braendle*, John E. Katsos**
}

\begin{abstract}
One of the main control mechanisms that shareholders have used to rein in rogue managers is compensation. Through a combination of intrinsic and extrinsic incentives, shareholders have tried to provide the right balance to motivate senior managers to perform at their best. Shareholders have often failed in achieving this balance through compensation. In this paper, we argue that this failure is not the result of compensation packages as such, but on the focus of compensation packages on extrinsic motivators such as pay-for-performance bonuses and stock options. Instead, the focus of compensation packages should be on cultivating intrinsic motivators such as firing and prestige.
\end{abstract}

Keywords: CEO, Compensation, Motivation, Corporate Governance, Agency Theory

* Udo C. Braendle is Associate Professor of Management and Chair of the Department of Business and Economics at the American University in Dubai and External Lecturer at the University of Vienna

E-mail: ubraendle@aud.edu

* John E. Katsos is Professor of Business Administration at the American Vniversity of Sharjah

E-mail: 返atsos@aus.edu

\section{Introduction}

The agency theory of the firm has come to dominate both the academic literature and the practical implementation of organizational control. Agency theory is premised on the ability of owners to control the actions of management to pursue the interests of shareholders and not their own selfinterest. Executive contracts are supposed to provide explicit and implicit incentives that align the interests of managers with shareholders. The empirical literature has usually focused on the sensitivity of pay (explicit incentives) and the dismissal of executives (implicit incentives) to corporate performance.

The high pay of executives was justified in the 1990 s and 2000 s by the extraordinary gains in wealth shareholders received. Incentive pay was even characterised as one of the driving forces for the high market valuation of US corporations (Holmstrom and Kaplan, 2001). Recently, though, executive pay has increased despite stagnant macroeconomic conditions and stock prices (see Carvalhal et al., 2012). Switzerland with its successful "people's initiative against fat-cat pay" is the latest example of this trend (Economist, 2013).

All forms of control by shareholders over management involve agency costs, therefore corporate governance revolves around finding control mechanisms that reduce agency costs. To achieve this goal, monitoring refers, on the one hand, to strategies of managerial supervision and, on the other, oversight to improve performance (Braendle and Noll, 2004). This explains the existence of board systems (Kostyuk, 2006) and other external monitoring such as rating agencies and institutional investors. On the other hand highpowered incentive contracts such as shares and stock-options to remunerate directors were implemented in most companies over the last years (Armstrong et al., 2012).

One of the main control mechanisms that shareholders have used to rein in rogue managers is compensation. Through a combination of intrinsic and extrinsic incentives, shareholders have tried to provide the right balance to motivate senior managers to perform at their best. Shareholders have often failed in achieving this balance through compensation. In this paper, we argue that this failure is not the result of compensation packages as such, but on the focus of compensation packages on extrinsic motivators such as pay-for-performance bonuses and stock options. Instead, the focus of compensation packages should be on cultivating intrinsic motivators such as firing and prestige.

We begin by examining the existing literature and paradigms on agency theory and managerial compensation. Next, we examine the existing literature on employee motivation. This literature indicates that intrinsic motivation leads to higher performance in non-programmable tasks and that extrinsic motivators like pay very often "crowdout" the effect of intrinsic motivators on the 
performance of employees, leading to poorer performance in spite of higher pay. In the third section, we analyse how the employee motivation literature might inform the current agency theory debate. We find that, based on the existing literature, shareholders may obtain better performance from their managers by reducing their level of pay, but increasing extrinsic motivators through compensation packages. In the fourth and final section, we suggest some areas for further research in the field to empirically establish connections between intrinsic motivation and performance among senior managers. We also note several limitations to the current paper and how they might be addressed in future studies.

\section{Agency Theory and Managerial compensation}

The principal-agent model is based on economic models related to the employment relationship (Holmstrom 1979). The underlying concept is that the principal wants the agent to do something on her behalf and therefore must motivate the agent to do so. That motivation can come in two forms: extrinsic and intrinsic. Extrinsic motivation is what we traditionally think of in the agency theory context and it takes the form of motivators outside of an individual such as pay. Intrinsic motivation is inside of an individual and usually derives from goal identification or task involvement (Staw 1989; Fuller and Dornbusch 1988).

Managers do not necessarily maximize shareholder value (Mueller 2003). As most of them only own tiny fractions of their companies' shares (if at all), the separation between ownership and control leads to a principal-agent problem (Bebchuk et al., 2011). The stockholders (principals) want their managers (agents) to maximize the value of the company and its shares. But managers may be better off pursuing a different strategy. We can expect the utility-maximizing manager to increase those elements in an input vector that give him personal utility (Conyon 2006). In other words, she will use some of her residual income to engage in on-the-job consumption, up to a point where the marginal utility from additional discretionary expenditures is near zero. The managerialdiscretion literature put forward some hypotheses concerning what it is that managers consume in excess: leisure (Edmans and Gabaix, 2009), sales (Baumol 1967), staff and emoluments (Williamson 1979), growth (Marris 1963, 1998) and income (Melis et al., 2012).

One of the key elements of agency theory is opportunism, a point stressed by Williamson (1979). If the agent has discretion which she is supposed to exercise for the benefit of another (the principal), she may exercise it to maximise her own utility instead. This is inefficient where the resulting loss to the principal exceeds the benefits to the agent. If the agent is rewarded by the principal on a basis which does not correlate her effort to the reward, the agent may not have the incentive to exercise the highest effort. The costs resulting from this agency problem includes both the loss of potential benefits and the costs of measures designed to reduce the loss of potential benefits. Jensen and Meckling (1976) identified these costs and termed them "agency costs".

Agency theory is based on the incompleteness of contracts and the separation of ownership and control. Though the resulting problems were already mentioned by Adam Smith in the 18th century, they were prominently highlighted by Berle and Means (1932). Due to the shareholders' perceived "limited liability" and the shareholders' inability in practice to control the management, the agency conflict is exacerbated. In academic circles, the shareholder and stakeholder visions of the firm have been battling for supremacy since at least the 1930s (Coase, 1937; Dodd, 1932). In general, the shareholder vision of the firm sees managers as being entrusted large amounts of ownership money and that regulation and shareholder control through Directors are the only means to stop management from abusing this trust (Muth and Donaldson, 1998; Jensen and Meckling, 1976). Again, generally, the stakeholder, or "other-regarding", vision of the firm sees managers and Directors as intermediaries among different groups with interest - beyond just financial - in the firm (Evan and Freeman, 1988). Shareholders are only liable to the company to pay up their share capital. In other words, they are sharing the company's profits, but they are not responsible for all of its losses. Limited liability, so the argument goes, shifts the risk of business failure from the company's shareholders to its creditors. Both, the companies' owners and managers therefore may have too much of an incentive to take risks, as the creditors would be the party which would suffer most in case of a bankruptcy. This could result in an inefficient use of resources (Bris and Welch, 2005)

The diversity and large number of shareholders in a typical public company cannot or will not exert effective control over the management for various reasons such as the existence of a coordination problem (Ingley et al., 2011). This includes problems of different interests of shareholders as well as bringing shareholders with the same beliefs together.

In general we refer to the collective action problem, where it might be rational for each of the shareholders not to engage in control (Braendle and Noll, 2004)

Due to the consequent danger of the inefficient use of resources there is a justification for correction. To reinforce the classical model of the company where the interests of the owners and 
managers of the company are aligned, regulatory measures - mainly in the form of laws and codes are used.

These include strengthening shareholders' voting rights, e.g. bolstering minority shareholder rights (Braendle, 2006). In addition the accountability of the management to shareholders is achieved by imposing penalties on managers when they behave wrongly (Bergstresser and Philippon, 2006). Furthermore, enforced publicity and disclosure should reduce the asymmetric information between the parties and therefore lead to better control (Braendle and Noll, 2005). All of these measures are reflected in corporate governance reforms around the world (Mallin, 2012).

Public companies are not required to have shareholders personally vote their shares because the number of shareholders is too large and their locations too diverse. As a result, shareholders instead often vote by proxy. Traditionally, access to the proxy ballot was only provided to senior management and board of directors. Recently, however, the SEC granted shareholders access to the proxy ballot in order to nominate at most one director (SEC, 2010).

So-called "say on pay" votes are a means of giving shareholders the ability to challenge management compensation packages. The recently passed Dodd-Frank Financial Reform bill (2010) requires public companies to have "say on pay" votes. These votes are advisory in that directors are not bound by the decision of shareholders with respect to executive compensation.

The major goals of allowing proxy access to shareholders and "say on pay" votes were to increase shareholder democracy and make management more responsive to the needs of others - whether these are shareholders or stakeholders (SEC, 2010, p. 331). The purpose of increasing shareholder democracy and making management more responsive is presumably to reduce the amount of excessive risk-taking and poor ethical and legal decisions made by executives of public companies over the past decade. Yet the poor decisions of company management and their excessive risk-taking seem to be more directly attributed to short-termism.

Short-termism is the "the obsession with short-term results by investors, asset management firms and corporate managers" (Krehmeyer et al., 2006). Theorists of multiple persuasions see shorttermism as a major problem that might be fixed through changing executive compensation structure, likely via "say on pay" and proxy access rule changes (along with other proposals). Theorists traditionally associated with the shareholder (Fuller and Jensen, 2002) and stakeholder (Evan and Freeman, 1988) visions agree not only that shorttermism is a problem, but that it must urgently be fixed. Though law and management theorists have come up with a variety of proposals to solve shorttermism, most relate, in some way, to simply adjusting the criteria by which senior management is incentivized (Bebchuk et al., 2011).

Though executive compensation is certainly not the only facet of corporate governance, it is easier to measure compensation of executives than, the relative power or prestige of being the CEO of one company or another. So it is not surprising that much of the literature which has tested for the effects of managerial discretion has looked at managerial compensation. Executive compensation in the USA has risen continuously since 1970, with the bulk of the increase stemming from granted option plans (Conyon and Murphy 2000).

\subsection{Base Salary}

The base salaries for executive officers are in most cases determined by benchmarks based on industry salary surveys. These surveys typically adjust for company size, reinforces the observed relation between compensation and firm size. Even though base salaries only make up a declining percentage of the total compensation, they are key component of executive employment contracts. As these salaries are fixed, risk-averse executives will naturally prefer a dollar increase in the base salary than in the variable bonus compensation.

\subsection{Bonus}

Almost any company offers an annual bonus plan based on performance over the year, covering all of its top executives. Despite heterogeneity across industries and companies, executive bonus plans can be categorized in terms of three basic components: performance measure, performance standards, and the structure of the pay-performance relation (Murphy 1999). Usually no bonus is paid until a minimum performance hurdle is reached commonly $80 \%$ of a budgeted target. Exceeding this hurdle, the manager receives a bonus, which increases as performance mounts. Target bonuses are paid for achieving the performance standard, and there is usually a "cap" on bonuses paid $120 \%$ of the target is common. The value between the minimum hurdle bonus and the cap is named the "incentive zone". The target is normally somewhere in the middle of this incentive zone.

Companies normally use accounting elements like revenues, net income, EBIT, etc., to measure the performance. The most common non-financial performance measures used in annual incentive plans is to quantify the deviation from ex ante specified objectives, customer satisfaction or plant security.

As long as the managers believe they can make the minimum hurdle, they will naturally try to 
increase performance - by legitimate means or, if push comes to shove, by illegitimate ones. According to the point on the pay line, they will either by pushing expenses into the future or shifting profits from present to the future.

Some companies even went further. The Swiss bank UBS implemented in 2008 the bonus-malus plan to remunerate its top executives (UBS, 2013). The main characteristic of the plan is that the bonus pay out is spread over several periods and that - in the case underperformance - a delayed pay out can be reduced or even set to zero. Underperformance is mostly based on the profit and loss results of the bank.

\subsection{Stock options}

Stock options are contracts which give the management the right to buy a share of stock at a pre-specified exercise price for a per-specified term. Stock options are a form of deferred compensation, i.e. an arrangement in which a portion of an employee's income is paid out at a date after which that income is actually earned.

These options normally become "vested", i.e. exercisable, over time: for example, $20 \%$ might become vested in each of the five years following grant. These options are non-tradable, and the exercise price is often "indexed" to the industry or markets. The mechanical explanation for the explosion in stock options, although unsatisfactory to economists, is rooted in institutional details on granting practices and exacerbated by the bull markets at the end of the end 90's and beginning of 21 st century. Therefore stock option which are not indexed to the relevant industry are in the line of fire, as managers can free ride on the positive temper on stock markets and profit from an environment where their own performance does not matter. Or the managers will try to increase the stock price in short term to cash in instead of implementing a long-term strategy.

Agents can game the competition system when they have multiple instruments at their control. This incentive problem has become known as multitasking (Holmstrom and Milgrom 1990; Baker 1992), where compensation on any subset of tasks will result in a reallocation of activities toward those that are directly compensated and away from the uncompensated activities. Using ratios like sales margin or return on assets as performance measure is dangerous, as it motivates gaming. That is because managers can increase the measure in two ways: either increasing the numerator or decreasing the denominator.

As we can see, both schemes are not incentive compatible and therefore lead to manipulations. The only way to solve the problem is according to Jensen (2001) to remove all the kinks from the payfor performance line shown above. His solutions are linear incentives and he convicts nonlinear, especially convex incentives as those will increase the variability.

But it is not easy to make a switch to adopt a linear compensation system. Target-based bonuses are deeply ingrained in minds of managers. For incentive compensation to work, corporate boards must choose both the right measures and the right levels of performance. In principle stock options employ the right measure of performance for corporate executives, but they do not set the right level. Shareholders expect boards to reward management for achieving superior returns - that is, for returns equal or better than those earned by the company's peer group or by broader market indexes. Stock options are often not indexed and therefore do not provide this possibility.

In the early 90 s it was the consensus view in the literature that the sensitivity of pay to performance in the United States was too low (Jensen and Murphy 1999). According to these studies executives did not receive enough cash after good corporate performance and did not incur sufficient losses, through dismissal, after poor performance. The same result was observed in other countries like Japan (Kaplan 1994). The change in executive wealth normalised by the change in firm value appears small and falls by a factor with firm size, but the value of the CEO's equity stake is large and increases with firm size. But the probability of dismissal remained unchanged between 1970 and 1995 (Murphy 1999).The use of equity based compensation and pay-performance sensitivity has risen in other countries as well, and in the UK the percentage of companies with an option plan has risen from 10\% in 1979 to over 90\% in 1985 (Main 1999).

It is hard to see just how changing executive compensation requirements to be more closely linked to actual performance through "say on pay" votes (Bebchuk et al., 2011) will have any effect on the "vicious cycle" created by short-termism (Lipton et al., 2009).

It is also hard to see why boards, shareholders, and legal theorists alike have largely ignored the rather large body of social psychology research that suggests that monetary rewards for performing a task (e.g. achieving the highest quarterly profit for a firm) actually decreases the effort put into a job that requires the accomplishment of multiple tasks by a performer - e.g. a CEO (Deci et al., 1999). If we accept the agency theory of the firm, that is, that management is simply the agent to its principals (Jensen and Meckling, 1976), i.e. shareholders, then we would also, by extension apply the research that relates to compensation of other employees in agency relationships. Social science research has also produced fairly convincing evidence that rewarding non-manual workers with explicit rewards for explicit tasks decreases performance 
for any non-rewarded task (Baker, 1992 as well as Holmström and Milgrom, 1990). Furthermore, incentive-based contracts for agents specifically reduce an agent's motivation to succeed in fulfilling his contract (Sliwka, 2003). It shouldn't be surprising then that when management is paid largely in accordance with the success or failure of a company's stock price would do so to the detriment of other important needs such as longterm shareholder wealth maximization and the interests of stakeholders.

This research thus suggests that management and law scholars might be focusing on fixing a system that is unable to actually capture what actually motivates senior management to act in the best interests of shareholders or stakeholders. Employees who are intrinsically motivated to do their jobs well do not need extrinsic motivators to succeed in their jobs. They simply need sufficient pay. During the 1950s and 1960s, senior management pay at public companies was substantially less linked to performance than it is today, yet firm growth was substantially stronger then than now (Frydman and Saks, 2007). If we take all of the research in this context seriously, we could easily come to a conclusion that is directly opposite from existing proposals to re-focus senior management on "better" priorities - eliminate pay for performance entirely and simply provide pay that is commensurate with the job.

\section{Employee Motivation}

Research on motivation within the psychology and social science literature has been pursued since at least the 1940s (Maslow, 1947; Fuller and Dornbusch, 1988). The prevailing view regarding motivation is that incentives are often a great motivator (Van Herpen et al., 2005). Motivators themselves fall into two categories. Extrinsic motivation is that which comes from outside an individual. Extrinsic motivation has been found to sharpen focus on individuals and allow them to accomplish manual tasks substantially faster than without incentives targeting extrinsic motivation (Deci, 1980). The most common incentive in the principal-agent relationship is an external motivator, namely, salary. In fact, all most of the executive compensation and economics literature focuses on extrinsic motivators. Only recently have economists and agency theorists had their attention drawn to the potential power of intrinsic motivation, the second category of motivation (Falk and Fehr, 2002). Intrinsic motivation is most often based on social norms, like reciprocity and fairness, that drive individuals to achieve some goal or task internal to themselves, even if the perceived benefits are to one's community or society (O’Reilly and Main, 2010; Fehr et al., 2007).
A robust set of research in psychology and behavioral economics indicates that extrinsic motivation (i.e. pay-for-performance) is counterproductive to success of a non-manual (i.e. thinking) task (e.g. Titmuss, 1972; Deci, 1980; Ariely et al., 2009; Camerer et al. 1997). A linked finding is that intrinsic and extrinsic motivation "crowd" one another out individuals only have a certain "pool" of motivation that they can draw from and too much of one type of motivation will force out the other. In other words, too much extrinsic motivation, like pay, will reduce the likelihood that individuals will be motivated intrinsically, for instance by a desire to reciprocate goodwill.

\section{Current intrinsic motivator: takeover threats}

Managers may behave opportunistically as we have seen above. In addition, agents in agent-principal relationships, including corporate executives, are often only motivated with extrinsic incentives, such as salary and stock options. Within current executive pay contracts, however, there does exist one major intrinsic motivational tool to encourage executives to do their best work: takeovers.

In a zero transaction costs world even a slight deviation of a company's market value from its potential maximum would lead someone to purchase a controlling interest in it and remove the management, alter its policies, and claim the wealth gain from bringing the company to its maximum value (Mueller 2003). This threat of a takeover was the chief constraint on managerial pursuit of growth, but sufficiently loose to allow managers to deviate significantly from shareholders'-wealthmaximising policies (Marris 1963). The term "market for corporate control" was introduced later on to describe this process, and it was argued that this "market" did provide sufficient discipline to constrain managers effectively.

When Marris discussed this process, one of the most radical mechanisms for disciplining managers, hostile takeovers (Becht et al. 2002), were sufficiently rare. This mechanism is highly disruptive and costly and therefore seldom used. On this issue, the analysis by Scharfstein (1988) stands out. Building on insights of Grossman and Hart (1986) he considers the ex-ante financial contracting problem between a financier and a manager. This contract specifies a state-contingent compensation scheme for the manager to induce optimal effort provision. In addition the contract allows for ex-post takeovers. The important observation made by Scharfstein is that even if the firm can commit to an ex-ante optimal contract, this contract is generally inefficient and will induce too few hostile takeovers on average. 
If hostile takeovers are a disciplining device for management, they should predominantly affect poorly performing firms. But this prediction is not borne out by the empirical literature. Successful US takeover targets are smaller than other companies, but that's the only difference from their peers (Comment and Schwert 1995). Furthermore, if hostile takeovers should correct managerial failure and enhance the efficiency, the value of the bidder and the target under joint control should be larger than the value of the bidder and the target separately. The empirical literature neither supports this prediction (Andrade et al. 2001; Burkart 1999).

Therefore takeovers do not seem to be an efficient measure to guarantee behaviour of the management in the sense of the shareholders.

\section{Well-balanced packages}

Agency theory predicts that incentive pay and takeover threats are substitutes (Kole 1997). This finding matches the findings of motivation theory which suggest that intrinsic and extrinsic motivators "crowd" one another out. Moreover agency theory predicts that incentive pay should be tied to performance relative to comparable firms, not to absolute performance. Early studies found that changes in the CEO cash compensation were negatively related to market performance, but positively related to firm performance (Gibbson and Murphy 1990). Equity-based compensation, in contrast, is most of the time not corrected for market stock index movements, consequently leading to a solid rejection of the relative performance evaluation hypothesis in all recent surveys due to accounting problems, tax considerations, difficulties in obtaining performance date from competitors (Abowd and Kaplan 1999; Bebchuk, Fried et al. 2001; Murphy 1999).

Agency theory can be used to determine the optimal exercise price of granted options. The options with an exercise price equal to the company's stock price, which are very common in practice, are a clear contradiction of the predictions of this theory (Bebchuk et al. 2001:69). Theory also predicts that incentive schemes and the adoption of the latter should result in an increase in shareholder wealth. The latest empirical literature generally rejects this prediction, whereas earlier event studies generally support it (Habib and Ljungqvist, 2001).

Furthermore, firms subject to blockholder monitoring are less likely to implement stock option plans (Kole 1997), because more discipline substitutes for more sensitivity of pay. Managements protected by anti-takeover laws or anti-takeover amendments provide more incentive pay to compensate for less discipline from hostile takeovers, while in the UK takeover threats are higher while incentive pay and the level of pay are lower than in the US (Conyon and Murphy 2000). However, this theory is not consistent with what we observe. Companies in industries with more disciplining takeovers should therefore pay less, while in fact they pay more.

In addition to these explicit incentives, implicit incentives take the form of executive dismissal or post-retirement board services. In the US, this latter point seems to be true, as $75 \%$ of the CEOs are holding at least one directorship after retirement. This is a point which is opposed by many corporate governance codes.

\section{Conclusion of these measures}

It has become difficult to maintain the widely held view of the 90 s that US pay practices provide explicit and implicit incentives for aligning the interests of managers with those of the shareholders. On contrary, it seems that the managers have got the possibility and the power to set their own wage at the expense of shareholders (Bebchuk et al. 2001). Long-standing debates all over the world show that the opinions are controversial.

We suggest a new approach with the help of penalties for the management. Instead of designing a "standard" contract with a base salary and a bonus if a certain given project is successfully enforced, the shareholder can think about a contract with a higher bonus for a successful project and a penalty for failure.

\section{References}

1. Abowd, J., Kaplan, S. (1999), Executive Compensation: Six Questions That Need Answering, 13 Journal of Economic Perspectives, pp. 145-168

2. Alchian, A., Demsetz, H. (1972), Production, Information Costs and Economic Organization, 62 American Economic Review,.777-795.

3. Andrade, G., Mitchell, M., Stafford, E. (2001), New Evidence and Perspectives on Mergers, 15 Journal of Economic Perspectives, pp. 103-120

4. Armstrong, C., Ittner, C., Larcker, C. (2012), Corporate governance, compensation consultants, and CEO pay levels, 17 (2) Review of Accounting Studies, pp. 322-351

5. Baker, G. (1992), Incentive Contracts and Performance Measure, 100 Journal of Political Economy, pp. 598-614

6. Baumol, W. (1967), Business Behavior, Value and Growth, New York: Macmillan

7. Bebchuk, L., Fried, J., Walker, D. (2001), Executive Compensation in America: Optimal Contracting Or Extraction Of Rents?, NBER Working Paper No. 8661

8. Bebchuk, L., Cremers, M., Peyer, U. (2011), The CEO Pay Slice, 102 Journal of Financial Economics, pp. 199-221 
9. Becht, M., Bolton, P., Roell, A. (2002), Corporate Governance and Control, ECGI Working Paper Series in Finance

10. Bergstresser, D., Philippon, T. (2006), Performance Pay and Top Management Incentives, 80 (3), Journal of Financial Economics, pp. 511-529.

11. Berle, A., Means, G. (1932), The modern corporation and private property, Macmillan, New York.

12. Brickley, J., Linck, J., Coles, J. (1999), What Happens to CEOs after They Retire? New Evidence on Career Concerns, Horizon Problems, and CEO Incentives, 52 Journal of Financial Economics, pp. 341-377

13. Braendle, U., Noll, J. (2004), The Power of Monitoring, 5 German Law Journal, pp. 1349-1371

14. Braendle, U., Noll. J. (2005), A Fig Leaf for the Naked Corporation, 9 (1) Journal of Management and Governance, pp. 79-99.

15. Braendle, U. (2006), Shareholder Protection in the USA and Germany - "Law and Finance" Revisited, 7 German Law Journal, pp. 257-278.

16. Bris, A., Welch, I. (2005), The Optimal Concentration of Creditors, 60 (5) Journal of Finance, pp. 2193-2212

17. Burkart, M. (1999), The Economics of Takeover Regulation, Stockholm School of Economics Working Paper

18. Carvalhal, A., Sampaio, M., Ferreira, V. (2012), Corporate Governance and Executive Remuneration in Brazil, 9 (4) Corporate Ownership and Control, 918.

19. Coase, R.H. (1937), The Nature of the Firm, 4 (16) Economica, p. 386.

20. Comment, R., Schwert, W. (1995), Poison or Placebo? Evidence on the Deterrence and Wealth Effects of Modern Anitakeover Measures, 39 Journal of Financial Economics, 3-43

21. Conyon, M., Murphy, K. (2000), The Prince And The Pauper? CEO Pay In the US and UK, 110 Economic Journal, pp. 640-671

22. Conyon, M. (2006), Executive Compensation and Incentives, 20 (1) Academy Management Perspectives, pp. 25-44.

23. Deci, E., Koestner, R., and Ryan, R. (1999), A Meta-Analytic Review of Experiments Examining the Effect of Extrinsic Rewards on Intrinsic Motivation, 125 Psychological Bulletin, pp. 627668.

24. Dodd, E., For Whom Are Corporate Managers Trustees?, 45 Harvard Law Review, p. 1145

25. Dodd-Frank (2010), Dodd-Frank Wall Street Reform and Consumer Protection Act, Pub. L. 111203, H.R. 4173, §§ 951 and 971 (2010), available at http://docs.house.gov/rules/finserv/111_hr4173_fins rvcr.pdf, last accessed September 2, 2011.

26. Economist (2013), Fixing the fat cats, Economist 9th March 2013.
27. Edmans, A., Gabaix, X. (2009), Is CEO Pay Really Inefficient? A Survey of New Optimal

28. Contracting Theories, 15 (3), Europen Financial Management, pp. 486-496.

29. Evan, W. and Freeman, R.E., A Stakeholder Theory of the Modern Corporation: Kantian Capitalism, 97 Ethical Theory and Business, vol. 97,p. 101

30. Frydman, C., Saks, R.E. (2007), Executive Compensation: A New View from a Long-Term Perspective, 1936-2005, FEDS Working Paper No. 2007-35; AFA 2008 New Orleans Meetings Paper, http://ssrn.com/abstract=972399.

31. Fuller, J., Jensen, M. (2002), Just Say No to Wall Street: Putting a Stop to the Earnings Game, 14 (4) Journal of Applied Corporate Finance, pp. 41-46.

32. Gibbson, R., Murphy, K. (1990), Relative Performance Evaluation for Chief Executive Officers, 43 Industrial and Labor Relations Review, pp. $30-51$

33. Grossman, S., Hart, O. (1986), The Costs and Benefits of Ownership: A Theory of Vertical and Lateral Integration, 94 Journal of Political Economy, pp. 691-719

34. Holmstrom, B., Milgrom, P. (1990), Regulating Trade Among Agents, 146 Journal of Institutional Theoretical Economics, pp. 85-105

35. Ingley, C, Mueller, J., Cocks, G. (2011), The financial crisis, investor activists and corporate strategy: will this mean shareholders in the boardroom?, 15 (4) Journal of Management and Governance, pp. 557-587

36. Jensen, M. (2001), Corporate Budgeting in Broken Let's Fix It, Harvard Business Review (November), pp. 94-103

37. Jensen, M., Meckling, W. (1976), Theory of the Firm: Managerial Behaviour, Agency Costs and Ownership Structure, Journal Financial Economics, 305-360.

38. Jensen, M., Murphy, K. (1990), CEO Incentives: It's Not How Much You Pay, But How, Harvard Business Review (May/June), pp. 138-153

39. Kaplan, S. (1994), Top Executive Rewards and Firm Performance: A Comparison of Japan and the United States, 102 Journal of Political Economy, pp. 510546

40. Kaplan, S., Holmstrom, B. (2001), Corporate Governance and Merger Activity in the U.S.: Making Sense of the 1980s and 1990s, The journal of economic perspectives, 15, 121-144

41. Kole, S. (1997), The Complexity of Compensation Contracts, 43 Journal of Financial Economics, pp. 79-104

42. Kostyuk, A. (2006), Corporate Board Practices, Virtus Interpress

43. Krehmeyer, D., Orsagh, M., and Schacht, K. (2006), "Breaking the Short-Term Cycle", The CFA Institute and Business Roundtable Institute for Corporate Ethics, Charlottesville, VA, 2006. 
44. Lipton, M., Lorsch, J., Mirvis, T. (2009), Schumer's Shareholder Bill Misses the Mark, Wall Street Journal, May 12, 2009, 253(110), A15

45. Main, B. (1999), The Rise and Fall of Executive Share Options in Britain, in: Carpenter, J., Yermak, D. (eds), Executive Compensation and Shareholder Value: Theory and Evidence, pp. 83-113, Kluwer Academic Press

46. Mallin, C. (2012), Institutional investors: the vote as a tool of governance, 16 (2) Journal of Management and Governance, pp. 177-196.

47. Manne, H. (1965), Mergers and the Market for Corporate Control, 73 Journal of Political Economy, pp. $110-120$

48. Marris, R. (1963), A Model of Managerial Enterprise, 77 Quarterly Journal of Economics, pp. 185-209

49. Marris, R. (1998), Managerial Capitalism in Retrospect, London: Macmillan

50. Melis, A., Carta, S., Gaia, S. (2012), Executive remuneration in blockholder-dominated firms. How do Italian firms use stock options?, 16 (3) Journal of Management and Governance, pp. 511-541

51. Mueller, D. (2003), The Corporation, London: Routledge
52. Murphy, K. (1999), Executive Compensation, in: Handbook of Labor Economics, Ashenfelter, O., Card, D. (eds.), North Holland, pp. 2485-2563

53. Muth, M., Donaldson, L. (1998), Stewardship Theory and Board Structure: A Contingency Approach, 6 (1) Corporate Governance, p. 5

54. Scharfstein, D. (1988), The Disciplinary Role of Takeovers, Review of Economic Studies 55, 185200.

55. SEC (2010), Facilitating Shareholder Director Nominations, Exchange Act Release No. 34-62764, Investment Company Release No. 29, 384 (Aug. 25, 2010), available at http://www.sec.gov/rules/final/2010/33-9136.pdf, last accessed September 12, 2011.

56. Sliwka, D. (2003), On the Hidden Costs of Incentive Schemes, IZA Discussion Paper Series no. 844, pp. 14-19.

57. UBS (2013), Compensation report, available at http://www.ubs.com, last accessed June 9, 2013

58. Williamson, O. (1979), Transaction-Cost Economics: the Governance of Contractual Relations, 22 Journal of Law and Economics, 233261. 


\title{
RISKS TO CONSIDER WHEN INVESTING OFFSHORE
}

\author{
N.J. Godi* , J. Young**
}

\begin{abstract}
When investors engage in international business, transactions and operations, they encounter additional risks compared to trading domestically. Different languages, currencies, jurisdictions, customs and habits can be translated into extra informational asymmetries and transaction costs that may affect the smooth operation of business. Political transitions can also play an important role in the success of an offshore investment, especially in a world full of political uncertainty. As such, mitigating offshore risks is a significant factor in the success of overseas projects, investments and contracts. As such, this paper aims to identify risks which investors are exposed to when investing offshore and ranking these risks in order of importance, based on a literature review as well as views and experiences of South African investment brokers registered with the Financial Services Board.
\end{abstract}

Keywords: Risks; Investors; Offshore Investments; Foreign Exchange; Market Risk, Exchange Rate Risk; Credit Risk; Liquidity Risk; Technological Risk

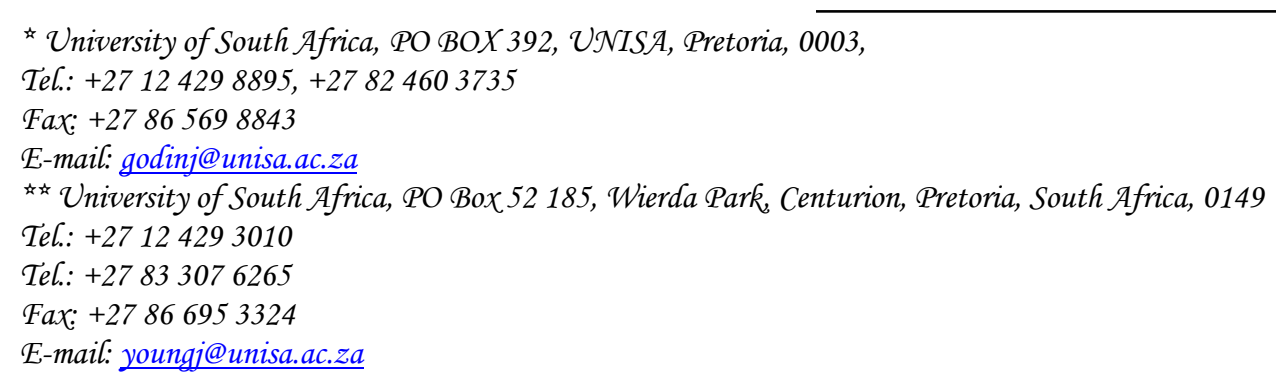

\section{Introduction}

Offshore risks have been acknowledged to have a relevant impact on investor's decisions due to losses suffered in the past. In some cases, offshore risks have forced several major investors into bankruptcy and throwing a number of businesses into disarray through job losses. Uncontrolled offshore risks can be regarded as one of the main reasons that lead to unfavourable results. According to Saunders and Cornett (2008), an offshoreoriented investor that mismatches the size and maturities of its foreign assets and liabilities is exposed to foreign currency and foreign interest rate risks. Even beyond these risks, and even when investing in dollars, holding assets in a foreign country can expose an investor to an additional type of foreign investment risks.

Regardless of the risk under consideration, investors strive toward an investment that yields the greatest possible income with the least possible risk. When choosing an investment, investors are advised to think carefully about how much risk they are willing to take. This is emphasised by Lucas (2009), who warns that while money may ensure security, placing capital in a high-risk environment could cause investors more concerns than the investment is worth. Additionally, in the volatile state of financial markets, the risk of investments should be considered more carefully than in stable markets. It is at times like these that investors are reminded that there is no such thing as risk-free investments. Everything has its price, and in the case of offshore investments, that price could be a result of offshore risks.

In the face of plunging markets, some investors discovered that they are not quite as tolerant to offshore risks as they might have thought. A number of investment portfolios are adjusted during difficult times, with investors adopting a mix of assets which they consider to be profitable in the long term. When reassessing investment portfolios, some offshore investors use risk analysis as an essential tool for adjusting their portfolios. Risk analysis is defined by Aven (2003) as a technique used to identify and assess the factors that may jeopardise the success of a project or of achieving a goal. This technique also helps to define preventive measures that can be used to reduce the probability of these factors from occurring and identify counter measures to deal with these constraints successfully. Therefore, analysis can help investors decide whether a given investment is too volatile or if the investment is not 
providing a return proportionate to the risk associated with it.

During the past number of years, the South African economy has developed rapidly and is affected by global market fluctuations. A number of South African investors are becoming global players by investing in foreign countries and markets. Thus, there are a number of risks to consider when considering doing business or investing in foreign countries. This paper seeks to identify and rate, in order of importance, the risks that should be considered when investing offshore. In support of this objective, the paper is divided into a brief literature review of the various risk types, followed by a methodology to determine the appropriate risks in order of importance that should be considered by offshore investors.

\section{Literature review}

Offshore risks vary from one country to the next. Some countries have high risks that discourage foreign investors. For example, when a domestic corporation is unable or unwilling to repay a loan, an investor usually recourses to the domestic bankruptcy courts and eventually may recoup at least a portion of its original investment when the assets of the defaulted firm are liquidated or restructured. By comparison, a foreign corporation may be willing but unable to repay the principal or interest on a loan. Most commonly, the government of the country in which the corporation is hosted may prohibit or limit debt payments because of foreign currency shortages and adverse political reasons.

In the event of such restrictions, rescheduling or outright prohibitions on the payment of debt obligations by sovereign governments, the investor has little, if any, recourse to the local bankruptcy courts or an international civil claims court. The major leverage available to an investor to ensure or increase repayment probabilities and amounts is its control over the future supply of loans or funds to the country concerned. However, such leverage may be very weak in the face of a country's collapsing currency and government (Saunders and Cornett, 2008).

In summary, the notion of offshore risk itself is very old and integrated into the assessment of risk and return in international operations. Usually, it was seen as inextricably linked with doing business abroad. When doing business abroad, investors need to consider a number of factors prior to investing offshore, since changes in political and economic policies can be detrimental to investors' success. According to Frenkel, Karmann and Scholtens (2004), politics is a major factor in determining the overall structure of financial markets and the regulatory framework. Countries have different rules that regulate investments in their countries. For this reason, offshore investors investing in countries that have unstable political economic systems should consider adding a risk premium when determining their required rate of return for these additional uncertainties. Risk premium refers to an increment in interest rates that would have to be paid for loans and investment projects in a particular country (Chapman, 2006). One way of establishing the risk premium for a country is to compare the interest rate that the market establishes for a standard security in the country to the comparable security in the benchmark country. For the securities to be comparable, they should have the same maturity and involve payment in the same currency.

The reason why the payments should be the same is that otherwise the differential in the interest rates would reflect the differential rates of inflation in the two countries instead of solely the market perceived risk of non-payment. The interest rate that is relevant is the market-determined yield to maturity rather than the coupon interest rate. The coupon interest rate is valid only if the issuers were careful to set the coupon rate so that it is equal to the yield to maturity of the security. For example, suppose the US government has issued a five-year bond that has a yield to maturity of $6 \%$ and the government of Poland borrows dollars by selling a five-year bond that pays in dollars and the yield to maturity of that bond is $8 \%$. The risk premium for Poland would be $2 \%$. The $2 \%$ is the correct value providing the yields to maturity, which is expressed as instantaneous rates. If they are expressed as effective annual rates then the correct computation of the risk premium $(\rho)$ is as follows:

$$
\begin{gathered}
1+\rho=(1+0.08) /(1+0.06)=1.01887 \\
\text { and thus } \\
\rho=0.01887
\end{gathered}
$$

The above procedure is easily implemented if a country's government borrows through securities denominated in dollars. This is common among the various emerging market economies but rare in the developed economies. Developed countries like the United States are generally considered the benchmark for low country risk, and most nations can have their risk measured as compared to the United States (Huang, 2009).

Political analysts as well as economic analysts are increasingly drawn into the debate of the interplay between politics and stock markets. In this regard, Moran (1998) warns investors that, if different political parties manipulate the economy according to their policies, the results would be reflected on the stock market. For example, there was instability in the South African stock market prior to the outcome of the African National Congress (ANC) policy conference in Mangaung in December 2012. In addition, it is assumed that 
electoral uncertainty is directly related to stock market volatility and that political events, such as the election of a politician who is expected to enact market-friendly policies, lead to increases in stock market returns. Conversely, political events that are expected to have a negative impact on the economy and specific businesses lead to decreases in stock market returns. Therefore, it can be deduced that political variables cause fluctuations in stock market returns. According to Saunders and Cornett (2008), political variables take many different shapes and forms as changes in domestic and foreign policy, as well as uncertainty brought about by national elections. The re-distribution of political power could have important implications in the future political and economic course of a country.

Consequently, an election brings a major uncertainty to both domestic and foreign investors. Although exchange control regulations in South Africa have been dramatically eased since 1996, investors still need to follow a bureaucratic process when they wish to invest offshore using the R2m foreign investment allowance (Thorne and Cloete, 2010). Investors should ensure that they follow domestic as well as international rules and regulations during international investments. Some trade agreements are extremely convoluted and complicated and may involve not just one international agreement between two countries, but agreements between multiple countries. As a result, international investments can be confusing and difficult to maintain, particularly if those investments span several different industries. As the aim of this paper is to identify risks that should be considered when investing offshore, the next section will briefly discuss the possible offshore risks that could be detrimental to an offshore investment plan.

\subsection{Risk types to consider when investing offshore}

Most investors are debating the differences between risk types. Although some regard this debate as semantic, it is necessary to clearly define each risk type that need to be considered when investing offshore. This understanding will allow investors to identify the risk proactively and manage it, thus protecting their investments and assisting them in making the most appropriate investment decisions. Some of the primary offshore risks to be considered are identified in this section.

\subsubsection{Exchange rate risk}

According to Madura (2009), exchange rate risk is a form of risk that arises from the change in price or value of one currency against another currency. Whenever investors or companies have assets or business operations across national borders, they face exchange rate risk. As economic conditions, such as import and export change, exchange rates could change substantially. According to Madura and Fox (2007), each currency is valued in terms of other currencies, so that currencies can be exchanged to facilitate offshore transactions. The values of most currencies fluctuate over time because of market and government forces.

Exchange rates are thus affected by risks associated with a particular country. For example, there may be political or military involvement, and restrictions may be imposed. There are also commercial factors, like a major foreign customer becoming bankrupt or defaulting. Major customers in the domestic country can also default, however, they are not operating under unfamiliar legal or regulatory systems. It is possible for investors to insure themselves against such risks, but this can be costly.

A number of South African companies trade with companies overseas or obtain foreign capital abroad. As such, they are not insulated from exchange rate risk, political instability, inflation, economic policy, interest rates, unemployment and the economic growth rate that can lead to changes in exchange rates.

\subsubsection{Market risk}

Young (2006) defines market risk as the risk of a decrease in the value of a financial portfolio as a result of adverse movement in market variables such as prices, currency exchange rates and interest rates. In other words, market risk is an exposure arising from adverse changes in the market value of a financial instrument or portfolio.

Markets are highly competitive resulting in thousands of intelligent and well-backed analysts constantly scouring the securities markets searching for the best options. This competition means that investors should expect to find few, if any, investments that are obvious bargains. Market risk is therefore another important risk that needs to be addressed for the success of an offshore investment plan.

\subsubsection{Inflation risk}

Appel (2008) defines inflation as the overall general upward price movement of goods and services in an economy, usually measured by the consumer price index $(\mathrm{CPI})$ and the producer price index (PPI).

When inflation occurs (the cost of goods and services increase), the value of a currency decreases because investors will not be able to purchase as much with the same currency as they previously could. For example, if one Rand could buy three candy bars last year and today it can buy only two, 
the purchasing power of the Rand has decreased. In periods of declining price levels (deflation), the purchasing power of a currency increases.

Efforts on the part of government to curb the rate of inflation are usually accompanied by an increase in interest rates. Higher interest rates, in turn, increase the cost of credit, and this could eventually limit the demand for goods and services in a country. Some of the main factors, which have an influence on the interest rate as well as other factors, do not function in isolation, but have implications for many other aspects of a country's economy.

\subsubsection{Interest rate risk}

According to Whittaker (2009), interest rate is the rate payable on borrowed money. This rate is applied to the principal of a loan and can be compounded in many ways. For example, interest rates can be compounded daily, weekly, monthly or annually. According to Sharpe (2007), interest rate risk is a general increase or decrease in market interest rates as a result of the monetary policy of the central bank. After the central bank has adapted its general lending rate, those in the banking sector alter their own prime and other lending rates accordingly. This has a ripple effect throughout the entire economy and influences all economic activities because changes in interest rates affect cash, bonds and stocks (Bodie, Kane and Marcus 2004).

As a result, the risk of a particular investment could increase as interest rates increase. As risk increases, the cost of stocks decreases and investors may lose money. However, the converse is actually beneficial. For example, if interest rates are reduced, stock prices are bound to increase. Investors could make money by selling stock at a higher price. An increase in interest rates will increase the cost of capital (Chapman, 2006).

\subsubsection{Credit risk}

Wagner (2008) defines credit risk as a failure to make required debt payments on a timely basis or to comply with other conditions of an obligation or agreement. It may comprise, for example, the possibility that a bond issuer will default by failing to repay the principal amount and interest in the time agreed upon.

Movements of financial capital between countries are normally dependent on either credit or equity transfers. Credit is in turn dependent on the reputation or creditworthiness of an investor that takes responsibility for the funds. Actual credit losses depend on the collateral and netting agreements. In some (but not all) instances, collateral taken can be liquidated upon default to cover losses, while a netting agreement allows a portfolio of deals to be collapsed into a single payable or receivable (Wagner, 2008).

While the term credit risk can encompass credit scoring, it is more commonly used to refer to processes that entail human judgement. As such, it is necessary that offshore investors assess and review information about the counterparty. This might include the counterparty's balance sheet, income statement, recent trends in its industry, and the current economic environment. It is clear that credit risk provides another likely explanation of why the required rate of return is not always realised. According to Wagner (2008), default bonds are regarded as those bonds that constitute failure to pay interest. From an investor's point of view, insolvency can be regarded as a serious issue where the repayment of the capital sum in total or in part is at stake.

\subsubsection{Liquidity risk}

According to Tracy (2005), liquidity risk is an investment that has no immediate access to either the ability to buy or sell the investment, such as a stock or mutual fund, or the ability to access and withdraw funds, from a savings account. According to Gitman and Joehnk (2008), a liquid asset has some or more of the following features: can be sold rapidly; with minimal loss of value; any time within market hours. The essential characteristic of a liquid market is that there are ready and willing buyers and sellers at all times.

For the purposes of asset allocation, it is critical that illiquid asset classes be made comparable to liquid asset classes. An estimation procedure may help to assess the true risks and diversification benefits presented by illiquid asset classes more accurately. Even though the approach involves some assumptions, it should provide a better picture of the variations in illiquid returns. Usually when an investor acquires an asset, it expects that the investment will mature or that it will be sellable to another investor.

In either case, the investor expects to be able to convert the security into cash and use the proceeds for current consumption or other investments. The more difficult it is to make this conversion, the greater the liquidity risk. According to Rose and Hudgins (2005), an investor must consider two questions when assessing the liquidity risk of an investment, namely:

- how long will it take to convert the investment into cash; and

- how certain is the price to be received?

Similarly, uncertainty faces an investor who wants to acquire an asset, namely:

- how long will it take to acquire the asset; and

- how uncertain is the price to be paid? 
Based on the abovementioned discussion, it is clear that liquidity risk can be regarded as one of the key risks an investor should consider when investing offshore. Liquidity management will not only ensure that risks are kept minimal but also that opportunities presented are exploited.

\subsubsection{Legal risk}

According to Young (2006), legal risk is the risk arising from violation of or non-compliance with laws, rules, regulations, prescribed policies and ethical standards. This risk also arises when laws or rules governing certain products or activities of an organisation's customers are unclear or untested. According to Chapman (2006), legal risk is defined as failing to operate within the law, to be aware of legal obligations, to honour contractual commitments, to agree remedies for compensation with the offshore company in the event of default, and to show evidence that a corporation has operated within the law, or to recognise and effectively manage legal threats. According to Rose (1999), the scope of legal risk for a business may be considered to include, but is not limited to:

- breach of environmental legislation;

- inaccurate listing information in terms of misstatements, material omissions or misleading opinions; and

- breach of copyright

Offshore investors' objectives may be compromised when legal risk is not minimised in a foreign country. Failure to manage legal risk can result in the cancellation of offshore investment contracts, penalties, fines and termination of trading licenses in extreme cases, which will be detrimental to the investors' objectives in the international arena. However, when legal risk is managed, offshore investors can realise great benefits.

\subsubsection{Technological risk}

Technological risk has become a major concern for offshore investors in recent years. Since the 1980s, banks, insurance companies and offshore investment companies have sought to improve operational efficiency with major investments in internal and external communications, computers and an expanded technological infrastructure.

Technological risk arises when existing technology malfunctions or back-office support systems break down (Saunders and Cornett, 2008). According to Chapman (2006), technology risk refers to sources of risk that are considered to be embraced within the term technology. Technology risk includes the following, for example:

- a lack of investment in technology and the resultant erosion of the ability to compete; and

- inadequate technology governance, in particular, IT governance.
A general lack of adequate technology can lead to investors having to withdraw offshore investments as a result of an inability to compete and leading to frustrations and losses. When investors envisage offshore investments, they need to ensure that they can afford the technology needed to trade with their offshore counterparts. As such, there are technological factors that need to be considered by offshore investors before investing offshore.

In conclusion, the decision to invest offshore is not one to be taken lightly, as there are many risks that need to be considered, which could be detrimental to an offshore investment plan. According to the discussions of each risk type, it is apparent that offshore investments are not risk free. Thus, offshore investors need to assess each and every risk individually, to determine the extent of the risk exposure before making an investment. The next section will focus on certain risk-related control measures which could reduce the risk exposure when investing offshore.

\section{Research methodology}

The aim of the paper is to determine and rank, in order of importance, the risks that should be considered when investing offshore. As such the investment brokers registered with the Financial Services Board (FSB) and licensed to trade offshore were selected as the target population to respond to a closed structured questionnaire. A web-based questionnaire using LimeSurvey was used to collate data from the respondents. The SPSS statistical methodology was used for the analysis from where recommendations and conclusions were drawn.

According to the data obtained from the FSB, the investment industry in South Africa consisted of fifty-two (52) investment brokers in July 2011. However, it was confirmed that only twenty-eight (28) investment brokers were registered and licensed to trade offshore. A response rate of $44 \%$ was achieved which was regarded as sufficient to make reliable and valid conclusions.

\section{Discussion of findings}

The response was subjected to a descriptive statistical analysis process and focused only on the identified respondents, which has been at the forefront of offshore investments and plays a key role in the South African offshore investment market. According to empirical evidence obtained from the respondents, there are eight risks that should be considered when investing offshore. The respondents were requested to rate the importance of considering these risks from very important to irrelevant when investing offshore using the Likert scale below. 
Table 1. Responses concerning the level of the risk when investing offshore

\begin{tabular}{|c|c|l|}
\hline $\begin{array}{c}\text { Scale } \\
\text { value }\end{array}$ & Scale name & \multicolumn{1}{|c|}{ Scale description } \\
\hline 1 & Irrelevant & $\begin{array}{l}\text { Indicates that the risk is irrelevant to consider when making an offshore investment } \\
\text { decision according to the respondents' views and experiences. }\end{array}$ \\
\hline 2 & Unimportant & $\begin{array}{l}\text { Indicates that the risk is not important to consider when making an offshore } \\
\text { investment decision according to the respondents'views and experiences. }\end{array}$ \\
\hline 3 & Neutral & $\begin{array}{l}\text { Indicates that the respondents are neutral regarding the risk when making an offshore } \\
\text { investment decision according to their views and experiences. }\end{array}$ \\
\hline 4 & Important & $\begin{array}{l}\text { Indicates that the risk is important to consider when making an offshore investment } \\
\text { decision according to the respondents' views and experiences. }\end{array}$ \\
\hline 5 & $\begin{array}{l}\text { Very } \\
\text { important }\end{array}$ & $\begin{array}{l}\text { Indicates that the risk is very important to consider when making an offshore } \\
\text { investment decision according to the respondents' views and experiences. }\end{array}$ \\
\hline
\end{tabular}

The eight risks identified in the literature review were confirmed as risks that are important to consider when making an offshore investment decision. However, the respondents rated the risks' level of importance differently as indicated in the figure below.

Figure 1. Offshore risk', order of importance

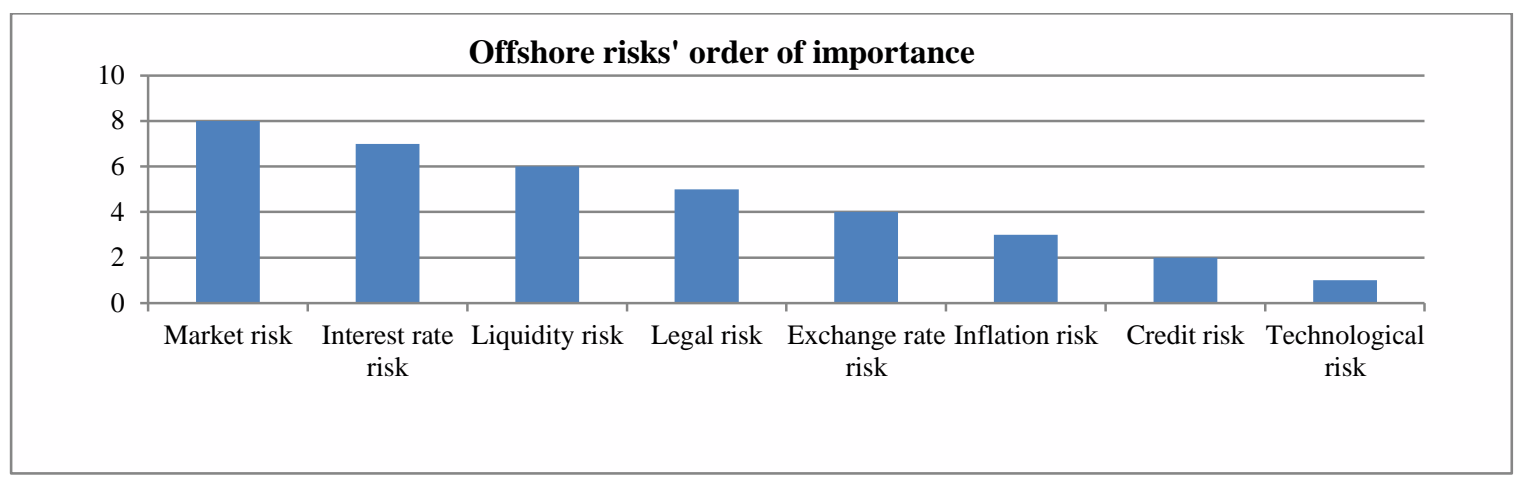

The above figure indicates that market risk should receive the most attention when considering investing offshore and technological risk should receive the least attention. When rating the importance of considering market risk during an offshore investment decision, $67 \%$ of the respondents regarded market risk as very important, while $33 \%$ regarded market risk as important. Market risk incorporates, to a lesser or greater extent, political decisions in offshore countries, monetary and fiscal policies, which could lead to losses if they are not in favour of investments in the country. Investors need to track the market trends in the offshore country, and unstable markets should not be considered.

Of the respondents, $67 \%$ regarded interest rate risk as very important to consider when making an offshore investment decision. Seventeen per cent regarded interest rate risk as important and the other $17 \%$ were neutral as far as interest rate risk is concerned. Interest rate fluctuations could negatively affect a perfect investment plan. Highly volatile markets have higher risks in relation to lower volatile markets. When diversifying investments in offshore countries, investors need to strike a good balance between these markets. Changes in interest rates influence the value of the investor's stocks, cash and shares. As a result, the risk of a particular investment could increase as interest rates increase, and decrease as interest rates decrease. Offshore investors need to be mindful of these movements.

In terms of liquidity risk, $67 \%$ of the respondents rated it as very important, while 33\% regarded it as important to consider when making an offshore investment decision. Liquidity risk can be regarded as one of the key risks an investor should mitigate when investing offshore. Liquidity management will not only ensure that risks are kept minimal but also that opportunities presented are exploited.

Sixty-seven per cent of the respondents regarded legal risk as very important, $17 \%$ rated it as important and $17 \%$ were neutral. Offshore investors' objectives may be compromised when legal risk is not adequately addressed before investing in a foreign country. It could, for example, result in the cancellation of offshore investment contracts, penalties, fines and termination of trading licenses, which will be 
detrimental to the investors' objectives in the international arena. However, when legal risk is managed effectively, offshore investors can realise great benefits.

When rating the importance of exchange rate risk during an offshore investment decision, $66 \%$ of the respondents regarded exchange rate risk as very important. Seventeen per cent regarded exchange rate risk as important while the other $17 \%$ regarded exchange rate risk as unimportant. The movement in exchange rate can enhance or reduce the value of an offshore investment; hence, it is vitally important to minimise this risk when making offshore investments.

Fifty per cent of the respondents regarded inflation risk as very important, 33\% rated it as important and $17 \%$ were neutral. When the general price level rises, each unit of currency buys fewer goods and services. Thus, it is important for offshore investors to take into account the inflation rate in the offshore country concerned and forecast the future trend and the potential influence on the planned investment.

The respondents were equally divided between very important and important when rating the credit risk and technological risk during an offshore investment decision. Although these risks were rated the lowest, it does not mean that they cannot be detrimental to an offshore investment. As such, it is also necessary to consider the potential influences of these risk types during an offshore investment decision.

Although the respondents rated the risk types in order of importance, not one risk type was rated as irrelevant or unimportant. Therefore, it can be deduced that all the identified risk types should be analysed and evaluated as part of an offshore investment decision. However, the success of an offshore investment cannot be limited to identifying and ranking the risks. The overall planning and execution of an offshore investment strategy remains vital for success.

\section{Conclusion}

The aim of this paper was to identify risks which investors are exposed to when investing offshore and ranking these risks in order of importance. The literature review discussed risks to be considered when investing offshore. This was followed by a research methodology which was used in this paper. Then the findings were discussed, which ranked the risks in order of importance according to the views and experiences of the respondents.

Offshore investments are based on the freedom to trade with the rest of the world, freedom to invest where the profits are favourable, and generally speaking the freedom to do business in any country. However, to exploit these international flows in profitability and safety conditions, it is necessary to identify and manage risks that could arise in the receiving economies.

As a global player, South African investment corporations exchange trades with corporations in other countries. These trades are, however, not risk free and trading in foreign markets can lead to corporations suffering losses if their investment plans are not well formulated and executed.

From the literature review, it is evident that there are many risks to consider when investing offshore. The risks were considered individually to assess the possible impact on offshore investments and thereafter ranked, amongst others, in terms of importance. Market risk was rated as the most important risk to consider when investing offshore, while technological risk was rated the least important.

In order of importance, the risks that should receive the highest attention from most important to the least important were ranked as follows:
1. Market risk
2. Interest rate risk
3. Liquidity risk
4. Legal risk
5. Exchange rate risk
6. Inflation risk
7. Credit risk
8. Technological risk

The above priority list is not exclusive to all offshore investors. However, it can be used as a guideline when considering risks of investing offshore.

\section{References}

1. Appel, M. 2008.Inflation targeting to stay, Mboweni. BuaNews, 6 August: 9.

2. Aven, T. 2003. Foundations of risk analysis: A knowledge and decision-oriented perspective. England: Wiley.

3. Bodie, Z., Kane, A. \& Marcus, A.J. 2004. Essentials of investment. $8^{\text {th }}$ Ed.New York: McGraw-Hill.

4. Chapman, R.J. 2006.Simple tools and techniques for enterprise risk management.

5. Chichester: Wiley.

6. Frenkel, M., Karmann, A. \& Scholtens, B. Ed. 2004. Sovereign risk and financial crises.

7. New York: Springer.

8. Gitman, L.J. \&Joehnk, M.D. 2008.Fundamentals of investing.Boston: Pearson Addison Wesley.

9. Huang, A. 2009.Moody's bond ratings, San Jose State University.Economic 202 [Online]. Available: http://www.sjsu.edu/faculty/watkins/econ202/risk.ht m [Accessed 15 April 2009]

10. Lucas, P. 2009. Risk analysis is an essential tool. Global investment strategist of Ashburton Investment Managers in Jersey [Online]. Available: 
http://www.btimes.co.za/98/1025/btmoney/money12 .htm/ [Accessed 19 January 2009].

11. Madura, J. 2009. International financial management. $9^{\text {th }}$ ed. United States of America: Thomson South-Western.

12. Madura, J. \& Fox, R. 2007.International financial management. United States of America: ThomsonSouth-Western/Cengage Learning.

13. Moran, T.H. ed. 1998.Managing international political risk. Massachusetts: Blackwell.

14. Rose, P.S. 1999. Commercial risk management. $4^{\text {th }}$ ed. Singapore: Irwin/McGraw.

15. Rose, P.S. \& Hudgins, S.C. 2005. Bank management $\&$ financial services. $6^{\text {th }}$ ed. New York: McGrawHill.

16. Saunders, A. \& Cornett, M.M. 2008.Financial institutions management: A risk management approach. $6^{\text {th }}$ ed..New York: McGraw-Hill.
17. Sharpe, W.F. 2007.Investors and markets: Portfolio choices, asset prices and investment advice. New Jersey: Princeton University Press.

18. Thorne, M. \&Cloete, S. 2010. Premiums \& problems. Article Edition No. 100. Cape Town: Old Mutual.

19. Tracy, B. 2005.Getting rich your own way: All your financial goals faster than you ever thought possible. New Jersey: Wiley

20. Wagner, N. 2008.Credit risk: Models, derivatives, and management. Boca Raton: CRC Press

21. Whittaker, N. 2009. How do interest rates affect investments? [Online]. Available: http://ezinearticles.com/ [Accessed 20 August 2009].

22. Young, J. 2006. Operational risk management: the practical application of a qualitative approach. Pretoria: Van Schaik. 


\title{
ENHANCING ENVIRONMENTAL SUSTAINABILITY THROUGH CODES OF ETHICS: THE CASE OF ITALIAN LISTED COMPANIES
}

\author{
Silvia Testarmata*, Alessia Montecchia ${ }^{* *}$, Emiliano Di Carlo ${ }^{* * *}$
}

\begin{abstract}
Codes of ethics aims to disclose corporate social responsibility and to promote ethical culture throughout the firms. Several studies have investigated the content of such codes to identify what values are declared within. However, so far literature on codes of ethics seems not to have considered adequately the question of environmental protection. Therefore this paper focuses on the disclosure of environmental sustainability in codes of ethics, investigating the case of Italian listed companies. Adopting a content analysis methodology, the paper explores the environmental section of these codes in order to assess the salience of environmental sustainability in the strategic orientation of the firms, identifying the environmental principles, objectives, instruments and certification stated within the codes of ethics and highlighting whether and to what extent the environmental disclosure varies among industries. The research findings suggest that the Italian listed companies are more oriented to emphasize the environmental principles rather than to define precise objectives and instruments useful to achieve the environmental sustainability in practice. Nevertheless the more polluted industries seem to provide a wider environmental disclosure.
\end{abstract}

Keywords: Codes of Ethics, Environmental Sustainability, Italian Listed Companies

* Corresponding author, Unicusano University, Via Don Carlo Gnocchi 3, 00166, Rome, Italy

E-mail: silvia.testarmata@unicusano.it

* University of Rome 'Tor Vergata', Via Columbia 2, 00133, Rome, Italy

E-mail: alessia.montecchia@uniroma2.it

स女े University of Rome 'Tor Vergata', Via Columbia 2, 00133, Rome, Italy

E-mail:dicarloe@uniroma2.it

\section{Introduction}

The environmental disasters caused by companies (e.g. Exxon, British Petroleum) have generated a great deal of attention on the impact of business practices on environment and, more in general, on sustainability. Concern about the environment has become an emerging topic for regulators, scholars and business, generating an exponential interest in Corporate Social Responsibility (CSR) activities and reporting.

Most important international bodies (i.e., OECD, European Commission) invited companies to move beyond legal requirements, integrating corporate social responsibility as a strategic investment into their core business strategy, management instruments and operations (European Commission, 2001).

Several studies pointed out how many corporations reacted to these changes, integrating environmental issues into their mission statements and starting to adopt various instruments, such as the code of ethics or environmental, social or sustainable reporting (KPMG, 2008; Perrini, 2006).

Among all CSR instruments the code of ethics occupies a central role (Erwin, 2011; Lugli et al.,
2009; Mittal et al., 2008), since it can be considered an ethical tool employed to establish and communicate CSR policies and to develop ethical organizational culture (Kaptein, 2004; Schwartz, 2001; Van Tulder et al., 2009). Through codes of ethics companies declare their ethical responsibility and behaviours towards various internal and external stakeholders (Farrel and Cobbin, 2000; Winkler, 2011). Therefore the study of codes of ethics is an established field within business ethics research (Svensson et al., 2009; Winkler, 2011).

Numerous scholars have investigated the codes using a content analysis methodology (Helin and Sandström, 2007). Specifically, literature analyses country-specific features or industries; other studies compare codes issued in different countries; several articles emphasize different kind of ethical issues. However, academic research on the environmental sustainability in codes of ethics seems to be limited. Only few studies investigate whether and to what extent the industry sector may influence the content and the quality of codes of ethics (Lugli et al., 2009).

Therefore, the purpose of the paper is to fill this gap investigating the environmental section of such codes, trying to identify the features of the 
environmental sustainability's disclosure in codes of ethics and to identify the main differences among industries according to the general framework of legitimacy theory (Suchman, 1995). In other words, we aim to answer to the following research questions: what types of environmental issues are disclosed through codes of ethics? And, whether and to what extent the pieces of environmental information given to the stakeholders are affected by the industry sector in which the company operate.

To answer these questions, we present a content analysis investigating the codes of ethics of 230 companies, listed on the Italian Stock Exchange. The content analysis is focused on the environmental section of these codes. The empirical results highlight that companies are more oriented to emphasize the environmental principles rather than to define precise objectives and instruments useful to achieve the environmental sustainability in practice by converting the environmental values into rules of conduct. This is probably due to the fact that environmental protection is still considered by firms as an additional cost (Friedman, 1970) or as a regulation to comply with rather than as fundamental business strategy leading to a sustainable competitive advantage (Porter and Kramer, 2006).

In sum, this paper contributes to research on codes of ethics in the following ways: first, it explores the disclosure of the environmental sustainability in codes' content; second, it identifies the factors addressing the environmental orientation of the firm in codes of ethics; third, it highlights the differences in the environmental disclosure among industries.

Our results have several implications for scholars, practitioners and regulators. First, the study points out that there is a need to investigate more closely the environmental disclosure in codes of ethics, focusing on environmental instruments and standards. Second, the research findings suggest that the establishment of a code of ethics by itself is not enough; it should be supported by the adoption of strictly compliant rules of conduct and other ethical initiatives. Thus, a clear implication is that implementation and monitoring of codes of ethics are two critical steps for their effectiveness. Third, in order to develop the environmental sustainability in practice, the values stated in the codes of ethics have to be translated into organizations behaviour mainly through training and communication programs.

Therefore, the paper is organized as follows. In section two, the theoretical framework and the previous studies on codes of ethics are reviewed. In section three, the research design is presented. In this section our approach to use content analysis as suitable method to examine codes of ethics is discussed, then the data collection and data analysis are depicted. Next, the environmental sustainability's factors disclosed in codes of ethics are presented. In section four, the research results are presented and, consequently, in section five they are discussed. Finally, in section six the conclusions of the analysis and the research implications are presented.

\section{Theoretical framework and literature review on code of ethics}

Although several theories have been used to explain the motivations for both CSR and voluntary disclosure, a clear and recognized theoretical framework has not yet been developed. However, as pointed out by Deegan (2002), stakeholder, legitimacy and institutional theories should not be considered as separated frameworks since the fact they have been developed from a similar philosophical background and they all share some common characteristics. In fact, as also noted by Chen and Roberts (2010: p. 661), even if these theories have different level of perspective and specificity, they all are aimed to explain how organizations survive and, mostly important, they all emphasize that maximization of profit is not the only responsibility of business organizations.

Therefore, "the choice of broad theoretical framework depends on whether the researcher approaches the question of CSR from an economic or an ethical standpoint" (Holder-Webb et al., 2009: p. 499). In this debate, Chen and Roberts note "legitimacy theory is more appropriate when the research primarily focuses on how corporations manage their public image. [...] Institutional theory is considered the proper choice for studies that investigate a specific corporation structure, system, program $[\ldots]$ resource dependence theory and stakeholder theory are suitable for research interested in the relationship and interaction between two or more organizations and groups" (2010: p. 661-662).

Stemming from these considerations, we embrace a legitimacy perspective as a main explanatory theory to investigate what is the disclosure of the environmental sustainability in codes of ethics and wheter and to what extent the environmental content of such codes varies across industries. Legitimacy theory (Lindblom, 1994; Suchman, 1995) focuses on whether the principles of an organization are aligned with the value system of the society in which it operates, and whether an objective of organizations is to meet social expectations. Legitimacy theory, however, does not specify how the congruency between the organizational and societal values could be reached or what actions should be taken to pursue it (Chen and Roberts, 2010).

As noted by Dowling and Pfeffer (1975: p. 122), "organizations seek to establish congruence 
between the social values associated with or implied by their activities and the norms of acceptable behaviour in the larger social system of which they are part. Insofar, as these two value systems are congruent we can speak of organizational legitimacy. When an actual or potential disparity exists between the two value systems, there will exist a threat to organizational legitimacy".

Based on a systems-oriented point of view, legitimacy theory believes that each company is influenced by the society in which it operates but, in the same time, it uses corporate disclosure as a means to influence societal perceptions about its activities (Deegan, 2002; Pfeffer and Salancik, 1978; Woodward et al., 2001). Providing social and environmental information, organizations expect that society approve their actions and objectives and consequentially their survival (Dowling and Pfeffer, 1975; Parker, 2011).

Organizational legitimacy is a resource for survival but it can be also manipulated (Woodward et al., 2001). In this perspective, corporate social responsibility disclosure is a strategy tool that a company can use to respond to the various expectations of its stakeholders (McKinney et al., 2010; Perrini et al., 2007). Organizations seek to get a legitimacy status through different instruments commonly used to manage and communicate CSR practices. These instruments generally range from voluntary tools, as codes of ethics, to complex environmental management systems and communication tools (Clarkson et al. 2008; Gray, 2010).

As argued by notable authors (Kaptein and Schwartz, 2008; Lugli et al., 2009) code of ethics represents one of the main instruments for implementing CSR inside organizations and to communicate to follow an ethical behaviour towards the external environment. The application of the ethical values to the behaviour of the operators inside the firm increases the firm's reputation and improves its image, in order to generate trust on the outside. In this sense, code of ethics is not only an internal instrument, but also a point of reference for relations between the firm and the outside world (Lugli et al., 2009).

Langlois and Schlegelmilch (1990) define it as "a statement setting down corporate principles, ethics, rules of conduct, codes of practice or company philosophy concerning responsibility to employees, shareholders, consumers, the environment, or any other aspects of society external to the company" (1990: p. 522).

Since the diffusion of codes of ethics, the academic community has extensively studied them. Scholars generally address the content, output and implementation of codes of ethics (Helin and Sandström, 2007; Stevens, 1994).
Regarding content, research concentrates on country or non-country specific features (Lugli et al., 2009; O'Dwyer et al. 2006; Singh, 2006; Singh et al., 2005; Snell et al., 1999); specific industries (Dumas and Blodgett, 1999; Flanagan and Clarke, 2007; Gaumnitz and Lere, 2002; Kinchin, 2007; Preston et al., 1995; Sirgy et al., 2005); specific types of organizations (Asgary and Mitschow, 2002; Farrell and Cobbin, 2000; Preuss, 2009), and different kind of ethical issues (Gordon and Miyake, 2001; Kapstein, 2004; Singh, 2011; Valentine and Barnett, 2002). With respect to output, there is a lively discussion about the effectiveness and quality of codes of ethics highlighting what effects on behaviour they have (Adams et al., 2001; Erwin, 2011; Helin et al., 2011; Jensen et al., 2009; Kaptein and Schwartz, 2008; Lere and Gaumnitz, 2003; McKinney et al., 2010; Singh, 2011; Stevens, 2008; Winkler, 2011). In terms of implementation, studies ask why and to what extent companies and other organizations adopt codes of ethics (Adam and Rachman-Moore, 2004; Haxhi and van Ees, 2010; Valentine and Johnson, 2005) and communicate such documents (Bernardi and LaCross, 2009; LaCross and Bernardi, 2006).

Several studies have investigated the business codes of ethics from around the world to determine which ethical and social values are prevalent. For example, Dumas and Blodgett (1999) analysed 50 family business mission statements and identified the following as the most prominent core values: quality $(42 \%)$; commitment $(25 \%)$; social responsibility $(20 \%)$ and fairness $(18 \%)$. Kapstein (2004) investigated the codes of two hundred of the largest corporations in the world. He found the following prevalence of 'stakeholder principles' (i.e., values): transparency (55\%), honesty/truth $(50 \%)$ and fairness/impartiality $(45 \%)$, with no reference to social responsibility.

Lugli et al. (2009) examined the codes of ethics of companies operating in the private sector in Italy in order to identify any correlation among the characteristics and the contents of these documents. From the data analysis, they found that the environmental protection is one of the most declared social value $(62 \%)$ but examining the "conversion" of environmental questions into rules of conduct, only $52 \%$ of the codes contained concrete actions which the firm announced its intention to take in order to fulfil its duties towards the human society and the environment.

Erwin (2011) observed a significant relationship between the quality of codes and ethical performance. The author found that companies maintaining high quality were they are significantly presented among CSR ranking systems for corporate citizenship, sustainability, ethical behaviour and public perception. 
Despite the mixed findings of research studies on the effectiveness of corporate codes of ethics in influencing behaviour (Kaptein and Schwartz, 2008; Lugli et al., 2009), these codes are potentially valuable in corporate decision-making and they may be considered as a signal to stakeholders about the organizational values of the company (Clark and Leonard, 1998; McKinney et al. 2010; Schwartz, 2001; Singh et al., 2005).

However there is a lack of studies focused on the environmental disclosure in codes of ethics. Thus, the understanding of the determinants and effects of corporate environmental strategies is still not sufficiently investigated. Moreover, just few studies analyse the influence of the company's industry sector on the content and quality in codes of ethics (Lugli et al. 2009; Perrini et al., 2007). Thus, we attempt to fill this gap through a content analysis of the environmental disclosure in the codes of ethics of Italian listed companies in order to understand what are the environmental sustainability's factors disclosed in those codes and whether and how the industry sector affect the environmental disclosure. In other words, we aim to define to what extent companies are environmentoriented and if and how they disclose the value of environmental sustainability in their mission statements as well as their environmental policies (principles and objectives), instruments and certifications in codes of ethics.

According to legitimacy theory, we expect that the more the industry is pollutant the more the companies belonging to that industry care about environmental sustainability and extensively disclose this issue in the code of ethics (see, for example, Du and Vieira, 2012). This is due to the fact that companies aim to protect their public image and reputation and, as a result, that the more polluting industries (Clarkson el al., 2008), such us Oil and Gas, Utilities and Basic Materials are more sensitive to environmental sustainability.

\section{Research design}

The aim of the analysis is to identify how codes of ethics declare and communicate specific understanding of company's environmental sustainability. In other words, codes of ethics are the object analysed and the content analysis is the tool used to achieve this goal.

We adopt a content analysis to quantify and classify codes' information because this method provides researchers with a systematic approach to analyse large datasets (Krippendorff, 1980). Moreover, content analysis is a widely used method by which selected items of qualitative data are systematically converted to numerical data (Collis and Hussey, 2009) and it is extensively used in the analysis of code of ethics (Helin and Sandström, 2007; Gaumnitz and Lere 2004). Normally, the method provides to examine a document (in this study the code of ethics) and determine the coding units, such as a particular word, character, item or theme, which is found in the code of ethics. The next step is to construct a coding frame, which lists the coding units in the first column, leaving room for the analysis of each communication to be added on the horizontal axis. So, the analysis can be based on the frequency of occurrence and its percentage on the overall observations.

\subsection{Data collection and sample}

The sample includes all codes of ethics adopted by the Italian companies listed on the MTA (Mercato Telematico Azionario) of the Italian Stock Exchange. We selected these companies because they are the most visible Italian firms and, therefore, the most important as perceived by investors, business analysts and the public. At the end of the collection period (March 2011), 259 companies were listed.

Data collection started with visiting the web pages of the companies and searching for formal documents addressing business ethics issues (usually titled 'Code of ethics' or 'Code of conduct'). In most cases, the document has been found within the sections "Corporate Governance" or "Investor Relations" of the company's web sites. We collected 230 codes of ethics.

Concerning the sample composition, Table 1 shows the categories classifying companies by Stock Exchange segments whereas Table 2 illustrates the companies forming the sample categorized by industry sector.

Table 1. Sample composition by Stock Exchange segment

\begin{tabular}{lccc}
\hline MTA SEGMENTS & $\begin{array}{c}\text { Number of } \\
\text { firms }\end{array}$ & $\begin{array}{c}\text { Number of firms adopting a code of } \\
\text { ethics }\end{array}$ & $\begin{array}{c}\text { Percentages of firms adopting a code of } \\
\text { ethics }\end{array}$ \\
\hline FTSE MIB & 40 & 40 & $100 \%$ \\
FTSE MID CAP & 60 & 58 & $97 \%$ \\
FTSE SMALL CAP & 140 & 116 & $83 \%$ \\
FTSE MICRO CAP & 19 & 16 & $84 \%$ \\
TOTA $\boldsymbol{L} \boldsymbol{S}$ & $\mathbf{2 5 9}$ & $\mathbf{2 3 0}$ & $\mathbf{8 9 \%}$ \\
\hline
\end{tabular}

Source: our elaboration 
Table 2. Sample composition by industry sector

\begin{tabular}{lccc}
\hline SECTOR & $\begin{array}{c}\text { Number of } \\
\text { firms }\end{array}$ & $\begin{array}{c}\text { Number of firms adopting a code } \\
\text { of ethics }\end{array}$ & $\begin{array}{c}\text { Percentage of firms adopting a code } \\
\text { of ethics }\end{array}$ \\
\hline Oil and Gas & 5 & 5 & $100 \%$ \\
Basic Materials & 7 & 6 & $86 \%$ \\
Industrials & 63 & 55 & $87 \%$ \\
Consumer Goods & 47 & 44 & $94 \%$ \\
Health Care & 7 & 7 & $100 \%$ \\
Consumer Services & 30 & 25 & $83 \%$ \\
Telecommunications & 4 & 4 & $100 \%$ \\
Utilities & 19 & 17 & $89 \%$ \\
Financials & 57 & 49 & $86 \%$ \\
Technology & 20 & 18 & $90 \%$ \\
TOTALS & $\mathbf{2 5 9}$ & $\mathbf{2 3 0}$ & $\mathbf{8 9 \%}$ \\
\hline
\end{tabular}

Source: our elaboration

\subsection{Data analysis}

We empirically explore the content of corporate codes of ethics in the leading Italian listed companies looking at the disclosure of environmental sustainability.

First, data analysis began with the identification of the general structure of the documents. Generally, a code of ethics is structured on several parts, such as general principles; ethical norms regulating firm's relations with stakeholders; ethical behavioural standards; internal sanctions; implementation. In the next step, the analysis focuses on the actors addressed in the codes and additionally it concentrates on the tools of communication and dissemination of such documents. The following step of the study regards the analysis of the environmental sustainability's disclosure. Adopting an inductive approach it sought to identify the main issues addressed in the environmental section of the codes and, as a consequence, the similarities and differences existing among the codes of companies belonging to different industries.

The analysis of codes of ethics is manually done by one author and checked for accuracy by the second and third authors. Then, the dataset is analysed by descriptive statistics (frequencies and percentages) and the research results are discussed in the research findings section. Note that the percentages showed in the tables are obtained dividing the number of observations by the total number of firms adopting a code of ethics for each sector.

\subsection{Environmental sustainability's factors disclosed in codes of ethics}

Starting from codes of ethics observations we identify six broad categories in order to analyse the contents of the codes of ethics. The detected environmental sustainability's factors are as follows: (1) code of ethics dissemination; (2) salience of environmental sustainability; mission and environmental orientation; (4) environmental principles and objectives; (5) environmental instruments; (6) reference to specific certifications and environmental declarations.

We measure the disclosure of environmental sustainability's factors using binary indicators, specifying whether information was given about a factor of environmental sustainability or not. In the next paragraphs the environmental sustainability's factors disclosed in codes of ethics are explained.

\section{1) Code of ethics dissemination}

The first area of investigation identifies the scope of codes of ethics and the instruments used to disclose the firm's values and rules of conduct inside and outside the company.

\section{2) Salience of environmental issue}

This area analyses the salience of environmental sustainability in codes of ethics exploring the number of pages of codes and the presence of an environmental section (Gaumnitz and Lere, 2004). When the latter variable is present, we consider the number of pages and lines dedicated to it.

\section{3) Mission and environmental orientation}

The third area of investigation focuses on the mission declared by the companies with the aim to verify how the concepts of sustainability and the environment are specified therein.

Every organization defines its identity, purposes, and values and why it should exist through a mission statement. By defining the core values, purposes and goals, the mission statement clarifies the essence of an organization (Blodgett et al., 2011). It reflects the organization's values and clearly enumerates the reasons why the organization exists (Collins and Porras, 1995). It is a codification of the essential corporate behaviour (Trevino and Nelson, 2010).

Stemming from these considerations, we expect that the mission statements of Italian listed companies reflect their core values and environmental orientation. Hence each mission statement was content analysed for expressed environmental values. Specifically, we employ 
content analysis to verify the frequency of the words "environment" and "sustainability".

4) Environmental principles and objectives

The fourth area investigated is the "environmental principles and objectives". By this expression we refer to the environmental principles, which guide the firm in its activities. Consequently, we identify three categories most widely found in codes' contents: (1) the company claims to guide its actions to sustainability; (2) the code indicates the guiding principles of environmental policies; (3) the code indicates the objectives of environmental policies.

In order to identify if the company claims to guide its actions to sustainability, we verify if the company declares to orient its business towards sustainable development and, in particular, if it claims to take decisions and actions towards environmental sustainability. We consider that the code indicates the guiding principles of environmental policies if it refers to any principles, declared by the company, underpinning the environmental sustainability. Finally, we consider that the code indicates the objectives of environmental policies, if the firm declares the environmental objectives to pursue. These objectives represent an element of the environmental policy and, in the same time, the output of the environmental management system (Kirkland and Thompson, 1999).

\section{5) Environmental instruments}

This area analyses the instruments adopted by the companies to achieve the declared environmental sustainability objectives. The codes' observation allow us to divide these instruments into four broad categories: the adoption of an environmental management system; planning and control instruments (e.g., life cycle assessment; environmental auditing; environmental performance indicators); instruments of environmental reporting and communication to the market (e.g., integrated report; sustainability report; social report; environment report; environment statement; network development); other voluntary instruments (e.g., voluntary agreements; training programs; customers and stakeholders programs for national resources optimization; green procurement tools).

6) Reference to specific certifications and environmental declarations

The last area of investigation is the adoption of specific certifications and environmental declarations clearly included in the codes of ethics. The most widely mentioned certifications are: environmental certification systems (e.g., EcoManagement and Audit Scheme, ISO 14001, Environmental, health and safety), environmental product certifications (e.g., Eco-label) and other voluntary adherence to other environmental initiatives (e.g., Unep, Equator Principles, Global Compact).

\section{Research Findings}

From the analysis we found that codes of ethics are similar for shape and structure but different for quantity and transparency of the information available on environmental sustainability. The research findings of the content analysis on the environmental sustainability's factors in codes of ethics are presented as follows.

\section{1) Code of ethics dissemination}

With respect to the code dissemination our data - in line with other studies (Lugli et al., 2009) - confirm that codes of ethics are considered not only internal instruments, but also tools to disclose company values and rules of ethics to the general environment (see Table 3).

The codes composing the sample are normally addressed to directors, employees and collaborators. In particular, data reveal that greater attention is given to the employees (93\%), collaborators $(86 \%)$ and directors $(85 \%)$ by a large part of the industry sectors. In addition, $58 \%$ is extended to the subsidiaries of the issuer. However, it seems interesting to underline the high percentage $(70 \%)$ of codes that extend the application to external parties (e.g. suppliers, agents).

Table 3. Scope of code of ethics

\begin{tabular}{llllllll}
\hline SECTOR & Shareholders & Directors & Employees & Collaborators & Subsidiaries & External Parties & Generic \\
\hline Oil and Gas & $0 \%$ & $80 \%$ & $100 \%$ & $60 \%$ & $40 \%$ & $20 \%$ & $40 \%$ \\
Basic Materials & $0 \%$ & $67 \%$ & $83 \%$ & $83 \%$ & $50 \%$ & $83 \%$ & $0 \%$ \\
Industrials & $11 \%$ & $87 \%$ & $96 \%$ & $89 \%$ & $60 \%$ & $80 \%$ & $4 \%$ \\
Consumer Goods & $2 \%$ & $84 \%$ & $93 \%$ & $89 \%$ & $61 \%$ & $75 \%$ & $9 \%$ \\
Health Care & $14 \%$ & $71 \%$ & $100 \%$ & $57 \%$ & $57 \%$ & $71 \%$ & $14 \%$ \\
Consumer Services & $8 \%$ & $92 \%$ & $92 \%$ & $84 \%$ & $48 \%$ & $64 \%$ & $12 \%$ \\
Telecommunications & $25 \%$ & $75 \%$ & $100 \%$ & $75 \%$ & $50 \%$ & $25 \%$ & $0 \%$ \\
Utilities & $0 \%$ & $82 \%$ & $100 \%$ & $94 \%$ & $71 \%$ & $82 \%$ & $6 \%$ \\
Financials & $16 \%$ & $88 \%$ & $86 \%$ & $88 \%$ & $55 \%$ & $65 \%$ & $14 \%$ \\
Technology & $6 \%$ & $83 \%$ & $89 \%$ & $83 \%$ & $61 \%$ & $56 \%$ & $11 \%$ \\
TOTAL & $\mathbf{9 \%}$ & $\mathbf{8 5 \%}$ & $\mathbf{9 3 \%}$ & $\mathbf{8 6 \%}$ & $\mathbf{5 8 \%}$ & $\mathbf{7 0 \%}$ & $\mathbf{1 0 \%}$ \\
\hline Source:
\end{tabular}

Source: our elaboration 
As showed by Table 4, the most used disclosure instrument is the publication of the code of ethics on the company's website (37\%). The $33 \%$ communicate the code by hand delivery, especially in case of the new intake. Only $36 \%$ of the codes contemplate the training courses among the means of code of ethics dissemination.

Table 4. Tools for disclosing the code of ethics

\begin{tabular}{lccccccc}
\hline SECTOR & $\begin{array}{c}\text { Delivery } \\
\text { by hand }\end{array}$ & $\begin{array}{c}\text { Online } \\
\text { disclosure }\end{array}$ & Intranet & $\begin{array}{c}\text { Posted on } \\
\text { notice } \\
\text { board }\end{array}$ & $\begin{array}{c}\text { Declaration of } \\
\text { awareness }\end{array}$ & $\begin{array}{c}\text { On demand } \\
\text { to the proper } \\
\text { office }\end{array}$ & $\begin{array}{c}\text { Training } \\
\text { courses }\end{array}$ \\
\hline Oil and Gas & $40 \%$ & $40 \%$ & $40 \%$ & $0 \%$ & $0 \%$ & $40 \%$ & $60 \%$ \\
Basic Materials & $17 \%$ & $0 \%$ & $17 \%$ & $17 \%$ & $33 \%$ & $0 \%$ & $0 \%$ \\
Industrials & $27 \%$ & $36 \%$ & $18 \%$ & $15 \%$ & $15 \%$ & $18 \%$ & $36 \%$ \\
Consumer Goods & $34 \%$ & $41 \%$ & $18 \%$ & $11 \%$ & $11 \%$ & $16 \%$ & $36 \%$ \\
Health Care & $57 \%$ & $57 \%$ & $0 \%$ & $14 \%$ & $0 \%$ & $0 \%$ & $43 \%$ \\
Consumer Services & $20 \%$ & $28 \%$ & $16 \%$ & $12 \%$ & $4 \%$ & $20 \%$ & $32 \%$ \\
Telecommunications & $0 \%$ & $25 \%$ & $25 \%$ & $0 \%$ & $25 \%$ & $0 \%$ & $50 \%$ \\
Utilities & $59 \%$ & $35 \%$ & $35 \%$ & $6 \%$ & $12 \%$ & $18 \%$ & $47 \%$ \\
Financials & $39 \%$ & $39 \%$ & $24 \%$ & $4 \%$ & $27 \%$ & $12 \%$ & $29 \%$ \\
Technology & $28 \%$ & $39 \%$ & $17 \%$ & $11 \%$ & $22 \%$ & $22 \%$ & $50 \%$ \\
TOTAL & $\mathbf{3 3 \%}$ & $\mathbf{3 7 \%}$ & $\mathbf{2 0 \%}$ & $\mathbf{1 0 \%}$ & $\mathbf{1 6 \%}$ & $\mathbf{1 6 \%}$ & $\mathbf{3 6 \%}$ \\
\hline
\end{tabular}

Source: our elaboration

The cross-sector industry analysis highlights that the companies belonging to the Oil and Gas sector and to the Utilities sector pay more attention to the actual dissemination of the codes of ethics through the organization. In fact, most of these companies deliver the code by hand (respectively $40 \%$ and $59 \%$ ) and organize training courses to convert the ethical values into organizational behaviour (respectively $60 \%$ and $47 \%$ ).

2) Salience of environmental sustainability

Considering a number of 230 codes of ethics with a number of 19 pages on average, we found that $57 \%$ of codes have a paragraph, or a particular section, that illustrates the question of environmental sustainability. Based on the number of lines and pages dedicated to the environmental section, we found that, on average, the value of environmental sustainability is not stated but only mentioned in about half of the codes. In addition, where the environmental section is present it does not invest more than one page. In many cases, the company provides a separate section for the environmental issues without specifying policies and strategies to achieve the sustainable development of its activities. Many firms have sections or sub-sections in which declare, in a generic way, to protect the environment and to respect the environmental legislation, as showed by Table 5.

Table 5. Salience of environmental sustainability

\begin{tabular}{|c|c|c|c|c|c|c|}
\hline SECTOR & $\begin{array}{c}\text { Number of } \\
\text { firms } \\
\text { adopting a } \\
\text { code of ethics }\end{array}$ & $\begin{array}{l}\text { Number of } \\
\text { pages of the } \\
\text { code of ethics } \\
\text { (on average) }\end{array}$ & $\begin{array}{c}\text { Presence of } \\
\text { environmental } \\
\text { section/sub- } \\
\text { section/article }\end{array}$ & $\begin{array}{l}\text { Percentage of } \\
\text { presence of } \\
\text { environmental } \\
\text { section/sub- } \\
\text { section/article }\end{array}$ & $\begin{array}{c}\text { Number of } \\
\text { pages } \\
\text { dedicated to } \\
\text { environmental } \\
\text { section }\end{array}$ & $\begin{array}{c}\begin{array}{c}\text { Number of } \\
\text { lines }\end{array} \\
\text { dedicated to } \\
\text { environ- } \\
\text { mental section } \\
\text { (on average) } \\
\end{array}$ \\
\hline Oil and Gas & 5 & 33 & 5 & $100 \%$ & 1 & 30 \\
\hline Basic Materials & 6 & 16 & 5 & $83 \%$ & 1 & 19 \\
\hline Industrials & 55 & 21 & 38 & $69 \%$ & 1 & 16 \\
\hline Consumer Goods & 44 & 9 & 25 & $57 \%$ & 1 & 13 \\
\hline Health Care & 7 & 16 & 4 & $57 \%$ & 1 & 6 \\
\hline Consumer Services & 25 & 16 & 15 & $60 \%$ & 1 & 6 \\
\hline Telecommunications & 4 & 17 & 0 & $0 \%$ & 0 & 0 \\
\hline Utilities & 17 & 30 & 17 & $100 \%$ & 1 & 23 \\
\hline Financials & 49 & 17 & 16 & $33 \%$ & 1 & 13 \\
\hline Technology & 18 & 17 & 7 & $39 \%$ & 1 & 6 \\
\hline TOTAL & 230 & 19 & 132 & $57 \%$ & 1 & 13 \\
\hline
\end{tabular}

Source: our elaboration 
As we expected, the empirical results of the cross-sector industry analysis highlights that the more polluted industries, such as Oil and Gas, Basic Materials and Utilities, on average present a higher percentage of presence of environmental section (respectively $100 \%, 83 \%$ and $100 \%$ ) and dedicates a wider space to the environmental sustainability's disclosure in codes of ethics (respectively 30, 19 and 23 lines).

3) Mission and environmental orientation

The findings of the mission statements analysis are shown in Table 6. From the analysis, a limited orientation to the principles of sustainability and environment protection emerges. Only 139 mission statements $(60 \%)$ have been detected, thus analysed. As a result, only $9 \%$ makes specific reference to "environmental sustainability" and $12 \%$ contains the word "environment" or equivalent. It seems that most companies do not perceived the environmental sustainability as a strategic aim and the environment protection as a part of their business strategies.

Table 6. Mission and environmental orientation

\begin{tabular}{lccc}
\hline SECTOR & Missions Available & Sustainability & Environment \\
\hline Oil and Gas & $80 \%$ & $0 \%$ & $0 \%$ \\
Basic Materials & $33 \%$ & $0 \%$ & $50 \%$ \\
Industrials & $65 \%$ & $8 \%$ & $8 \%$ \\
Consumer Goods & $57 \%$ & $8 \%$ & $12 \%$ \\
Health Care & $57 \%$ & $0 \%$ & $0 \%$ \\
Consumer Services & $52 \%$ & $8 \%$ & $8 \%$ \\
Telecommunications & $75 \%$ & $0 \%$ & $0 \%$ \\
Utilities & $71 \%$ & $25 \%$ & $42 \%$ \\
Financials & $51 \%$ & $8 \%$ & $0 \%$ \\
Technology & $83 \%$ & $7 \%$ & $20 \%$ \\
TOTAL & $\mathbf{6 0 \%}$ & $\mathbf{9 \%}$ & $\mathbf{1 2 \%}$ \\
\hline
\end{tabular}

Source: our elaboration

However, the cross-sector industry analysis partially confirms our expectation, in fact, on average, the companies belonging to the Basic Materials sector and to the Utilities sector quotes the word "environment" more often (respectively $50 \%$ and $42 \%$ ) than the others in the mission statements. The high percentage observed in the Basic Materials sector is probably due to the huge use of natural resources in this industry. On the contrary, the mission statement of the Oil and Gas companies point out the value creation for all the stakeholders. Nevertheless the environment could be seen as a stakeholder to protect and safeguard (Banerjee and Bonnefous, 2011; Gibson, 2012; Schwartz, 2011) according to the triple bottom line approach to corporate social responsibility (Carroll, 1979).

4) Environmental principles and objectives

The analysis of the environmental principles and objectives statements has shown a reluctance to declare policies and strategies towards environmental sustainability. Table 7 presents the percentages of environmental policies expressly declared.

Table 7. Environmental principles and objectives

\begin{tabular}{lccc}
\hline SECTOR & $\begin{array}{c}\text { The company claims to } \\
\text { guide its actions to } \\
\text { sustainability }\end{array}$ & $\begin{array}{c}\text { The code indicates the guiding } \\
\text { principles of environmental } \\
\text { policies }\end{array}$ & $\begin{array}{c}\text { The code indicates the } \\
\text { objectives of environmental } \\
\text { policies }\end{array}$ \\
\hline Oil and Gas & $100 \%$ & $100 \%$ & $100 \%$ \\
Basic Materials & $0 \%$ & $83 \%$ & $67 \%$ \\
Industrials & $29 \%$ & $73 \%$ & $67 \%$ \\
Consumer Goods & $32 \%$ & $57 \%$ & $45 \%$ \\
Health Care & $43 \%$ & $57 \%$ & $29 \%$ \\
Consumer Services & $0 \%$ & $68 \%$ & $48 \%$ \\
Telecommunications & $0 \%$ & $25 \%$ & $0 \%$ \\
Utilities & $71 \%$ & $100 \%$ & $100 \%$ \\
Financials & $14 \%$ & $35 \%$ & $29 \%$ \\
Technology & $28 \%$ & $44 \%$ & $33 \%$ \\
TOTAL & $\mathbf{2 7 \%}$ & $\mathbf{6 0 \%}$ & $\mathbf{5 1 \%}$ \\
\hline S
\end{tabular}

Source: our elaboration 
Only $27 \%$ on average claims to guide its action to environmental sustainability and protection. As we expected, according to legitimacy theory, the percentage is higher in the Oil and Gas sector $(100 \%)$ and Utilities sector (71\%). Obviously, we can explain this difference looking at the diverse nature of what is produced in these industries. In other words, it seems that the grater attention given by these industries to the environmental policies is justified by the major impact that companies' activities and processes have on the environment ( $\mathrm{Du}$ and Vieira, 2012; Shrivastava, 1995), especially in terms of pollution (Freedman and Jaggi, 2005). The salience of environmental sustainability is even confirmed in the definition of the guiding principles and objectives, where the percentage is $100 \%$ of the companies belonging to these sectors.

It is important to highlight that, in very rare cases, the guiding principles of environmental policy are specified in a particular section, whereas they are quite often generically mentioned in the disclosure of the business activity orientation. However, $60 \%$ of companies on average indicate the guiding principles of environmental policy within the code of ethics. In most cases, specific reference is made to law compliance and preservation of natural resources.

\section{5) Environmental instruments}

The disclosure regarding the instruments adopted by the companies to implement environmental policies and strategies show that only $20 \%$ of companies state to adopt an environmental management system (see Table 8). However, the cross-sector industry analysis highlights that this percentage is higher in the Oil and Gas (80\%), Utilities (65\%) and Basic Materials $(33 \%)$ sectors.

Table 8. Environmental instruments

\begin{tabular}{lcccc}
\hline SECTOR & $\begin{array}{c}\text { The company adopts an } \\
\text { environmental } \\
\text { management system }\end{array}$ & $\begin{array}{c}\text { Planning and } \\
\text { control } \\
\text { instruments }\end{array}$ & $\begin{array}{c}\text { Instruments of } \\
\text { environmental reporting } \\
\text { and communication to the } \\
\text { market }\end{array}$ & $\begin{array}{c}\text { Other } \\
\text { voluntary } \\
\text { instruments }\end{array}$ \\
\hline Oil and Gas & $80 \%$ & $80 \%$ & $20 \%$ & $100 \%$ \\
Basic Materials & $33 \%$ & $67 \%$ & $33 \%$ & $50 \%$ \\
Industrials & $18 \%$ & $22 \%$ & $11 \%$ & $35 \%$ \\
Consumer Goods & $20 \%$ & $25 \%$ & $2 \%$ & $23 \%$ \\
Health Care & $29 \%$ & $0 \%$ & $14 \%$ & $14 \%$ \\
Consumer Services & $4 \%$ & $8 \%$ & $4 \%$ & $28 \%$ \\
Telecommunications & $0 \%$ & $0 \%$ & $0 \%$ & $0 \%$ \\
Utilities & $65 \%$ & $65 \%$ & $47 \%$ & $53 \%$ \\
Financials & $2 \%$ & $4 \%$ & $2 \%$ & $10 \%$ \\
Technology & $28 \%$ & $22 \%$ & $11 \%$ & $11 \%$ \\
TOTAL & $\mathbf{2 0 \%}$ & $\mathbf{2 2 \%}$ & $\mathbf{1 0 \%}$ & $\mathbf{2 7 \%}$ \\
\hline
\end{tabular}

Source: our elaboration

A greater percentage (22\%) states to use specific planning and control instruments to monitor environmental performance, however the declarations of the applied instruments are rare. As we expected, the percentage is higher in the Oil and Gas (80\%), Basic Materials (67\%) and Utilities $(65 \%)$ sectors.

In addition, the instruments adopted for the environmental reporting and disclosure to the market are mentioned only in the $10 \%$ of the observations. However, the percentage is higher in the Utilities (47\%), Basic Materials (33\%), and Oil and Gas $(20 \%)$ sectors.

Finally, the other voluntary instruments are declared in the $27 \%$ of the analysed companies. But, the industry analysis highlights that this percentage is higher in the Oil and Gas (100\%), Utilities (53\%) and Basic Materials (50\%) sectors.

As a result, we can confirm our expectation about a grater attention to the ethical value of environmental sustainability by the more polluted industries.

6) Reference to specific certifications and environmental declarations

The results on environmental certifications and declarations reveal a limited disclosure of environmental certifications; only $28 \%$ of the sample declares the adoption of an environmental certification system. The most cited are the ISO 14001 and the Eco-Management and Audit Scheme. However, the cross-sector industry analysis highlights that this percentage is higher in the Oil and Gas (100\%), Utilities (53\%) and Basic Materials $(50 \%)$ sectors.

ISO 14001 in one of the most common certification adopted by thousands of companies worldwide and consists of monitoring internal environmental processes of the organization. KPMG (2008) reports that $51 \%$ of the Global Fortune 250 (G250) and $41 \%$ of the 100 largest companies by revenue (N100) are actually using 
ISO 14001. However, it addresses only environmental issues and so it is not a comprehensive sustainability framework. It is also process-focussed, not outcome-focussed, so the environmental outcomes could still be unacceptable, even if the process was itself certified (Hubbard, 2011).

The Eco-Management and Audit Scheme (EMAS) has also been widely adopted within Europe (Castro and Chousa 2006). However, like ISO 14001, it is limited to environmental and process issues. In addition, it has no impact outside Europe. KPMG (2008) reports that only $8 \%$ of the Global 250 and $5 \%$ of the N100 organisations use it.
In addition, we observe that the environmental product certifications receive less attention than process certifications. Only $1 \%$ of companies state the adoption of a product certification. The prevalence of system certificates on product certifications may be due to several factors, such as the type of company, the business strategy and the limited understanding whether product certifications can really stimulate purchases or not.

Finally, the mention of voluntary environmental initiatives is very rare $(2 \%)$ as shown by Table 9 . As we expected, this percentage is higher in the Oil and Gas (20\%), Basic Materials $(17 \%)$ and Utilities $(6 \%)$ sectors.

Table 9. Reference to environmental certification and declarations

\begin{tabular}{lccc}
\hline SECTOR & $\begin{array}{c}\text { Company declares } \\
\text { environmental certification } \\
\text { systems }\end{array}$ & $\begin{array}{c}\text { Company declares } \\
\text { environmental product } \\
\text { certifications }\end{array}$ & $\begin{array}{c}\text { Voluntary adherence to other } \\
\text { environmental initiatives }\end{array}$ \\
\hline Oil and Gas & $100 \%$ & $0 \%$ & $20 \%$ \\
Basic Materials & $50 \%$ & $0 \%$ & $17 \%$ \\
Industrials & $36 \%$ & $2 \%$ & $0 \%$ \\
Consumer Goods & $25 \%$ & $5 \%$ & $0 \%$ \\
Health Care & $14 \%$ & $0 \%$ & $0 \%$ \\
Consumer Services & $28 \%$ & $0 \%$ & $0 \%$ \\
Telecommunications & $0 \%$ & $0 \%$ & $0 \%$ \\
Utilities & $53 \%$ & $0 \%$ & $6 \%$ \\
Financials & $10 \%$ & $0 \%$ & $2 \%$ \\
Technology & $17 \%$ & $0 \%$ & $0 \%$ \\
TOTAL & $\mathbf{2 8 \%}$ & $\mathbf{1 \%}$ & $2 \%$ \\
\hline
\end{tabular}

Source: our elaboration

\section{Discussion}

Financial crisis has generated a growing demand for transparency in corporate governance disclosure, especially with respect to business ethics. However, despite the increasing attention to the corporate social responsibility, the research findings suggest that business companies seem to underestimate the role of environmental sustainability in code of ethics. However, by developing this exploratory study on the codes of ethics of 230 Italian listed companies in different industries we obtain four main insights regarding the environmental disclosure in codes of ethics.

First, the fact that firms seem not to integrate the concept of environmental sustainability within their mission statements suggests that they have different aims for the environmental declaration in the codes of ethics, varying from true assessments of environmental sustainability's orientation to marketing communications of 'doing good', such as window-dressing policies or green washing practises. This is probably due to the lack of mandatory requirements, standards and formats for the environmental disclosure in code of ethics.

Second, despite the large amount of information presented, companies are more oriented to emphasize the environmental principles rather than to define precise objectives and instruments to implement and manage environmental sustainability strategies. A number of companies emphasize very broad commitments to environmental protection, but neglect to provide details on how these commitments will be met. Moreover, in most cases, disclosing companies are at the very early stage in the adoption of environmental sustainability's approach. According to Lugli et al. (2009), the function of the environmental disclosure seems to be more communicating firm's position on environmental issues towards external partners than implementing ethical rules of conducts inside the organizations.

Third, the empirical results show that within codes of ethics there is little evidence of an extensive attention to environmental issues in terms of either quantity and/or quality. Nevertheless, the most "polluting" industries, such as Basic Materials, Oil and Gas and Utilities, are more active in declaring to act in a sustainable manner (see for example Du and Vieira, 2012). Conversely, a sustainable development should be not correlated with the kind of activities done but integrated and motivated as strategic aim (see, for examples, 
Flammer, 2013; Gibson, 2012; Porter and Kramer, 2006).

In other words, the environmental values stated in the codes of ethics seem to be affected by industry characteristics. According to Lugli et al. (2009), we suggest that companies choose to declare their orientation to the environmental sustainability, and more in general, to the corporate social responsibility, to obtain the consensus from the part of the society that is most sensitive to those issues and to improve their public legitimacy (Chen and Roberts, 2010; Clarkson et al., 2008).

It probably depends on the fact that most companies still view the environmental protection as barrier to profitability or as a regulation to comply with rather than fundamental business strategy leading to a sustainable competitive advantage. In other words, this lack of attention to environmental sustainability could be addressed to the huge investments that companies necessarily would be obliged to perform in order to renewal their production processes for adopting a sustainable approach to growth (see Sprinkle and Maines, 2010 for a review of the costs and benefits of corporate social responsibility).

Forth, an environmental sustainability's approach involves difficult choices because not all actions that reap benefits to society and environment also benefit shareholders, at least in the short term. Additionally, the investments to become sustainable are significant and often reflect their value in the long term (Flammer, 2013). Quite often scholars distinguish between companies that look to the environmental sustainability as a key factor to achieve a competitive advantage and those that are compliant with the minimum environmental requirements. The empirical results suggest that most of the Italian listed companies belong to the second category.

Thus, the research findings suggest that regulators could encourage firms to believe in the sustainable economic development in order to change their approach to the environmental sustainability from a mere principle declaration and/or a minimal compliance with the regulation to a truly environmental awareness and to become an "ecologically sustainable corporation" (Shrivastava, 1995).

\section{Conclusion and research implications}

Our research findings make several contributions to the literature. To best of our knowledge, this study is the first to theorize and provide empirical evidence on the features of environmental sustainability's disclosure in codes of ethics.

As a result, the empirical analysis identifies the factors of environmental sustainability disclosed in codes' content. However, the research findings point out that the environmental disclosure in the codes of ethics of the Italian listed companies seems to be limited, primarily for what concerns the environmental instruments and the ethical rules of conduct. This might be affected by the fact that the study is based on data collected in March 2011, just some months before that the Italian Government, according to the European guidelines, introduced into Italian law, the administrative responsibility of legal persons, companies and associations without legal personality, pursuant to Legislative Decree no. $231 / 2001$, for the commission of environmental offenses. So, for research purposes it seems interesting to study the evolution of codes of ethics to assess whether they have implemented the recent legislative changes on the administrative responsibility.

Additionally, the research findings highlights that there is a discrepancy in terms of environmental disclosure among Italian listed companies and suggest a standardization of this disclosure. Furthermore, the study is potentially significant for companies (e.g., SMEs) that have no experience in terms of environmental disclosure; in fact the empirical analysis highlights the more environmental oriented companies that could be examples to learn from to implement an environmental sustainable approach to the business activities.

Another interesting avenue for research is the study of the relationship between the adoption of administrative responsibility, and more generally of corporate social responsibility, and the reduction of the company's risk profile because, as argued by Orlitzky and Benjamin (2001), the adoption of an ethical and social responsible conduct could reduce the firm risk in practice.

In conclusion, our research findings have several implications for scholars, practitioners and regulators for what concerns the disclosure of environmental sustainability throughout codes of ethics.

First, the study points out that there is a need to investigate more closely the environmental disclosure in codes of ethics, focusing on environmental instruments and standards. Hence further research on disclosure of planning and control systems, environmental reporting and standards adopted by companies is needed.

Second, the research findings suggest that the establishment of a code of ethics is not enough; it should be supported by the adoption of strictly compliant rules of conduct and other ethical initiatives. Thus, a clear implication for practitioners is that not only codes development and contents but also codes implementation and monitoring are critical for their effectiveness (Erwin, 2001; Singh et al., 2005).

As a result, research efforts should examine how environmental values are implemented in the organizations in practice, focusing on 
environmental managing and reporting system. In order to develop an environmental sustainability culture in the organizations, the environmental values included in codes of ethics need to be transferred into the organizations behaviour through training and communication programs (McKinney et al. 2010). These programs have to underline that the achievement of a long-term competitive advantage is affected by both external and internal factors.

Among the external factors (e.g. the behaviour of other companies, the environmental awareness of consumers and civil society, the conditions of the natural environment and the laws and regulations which the company is subject), the greater social awareness of environmental issues plays a central role, creating a new market for business companies that is more careful in respect to the environmental protection and the proper management of natural resources (Flammer, 2013). This demand raises the pressure exerted by the external parties on the organizations behaviour. More specifically it can be assumed that the main advantage achieved with the environmental sustainability of the firm is an improvement in terms of reputation that results in greater customers' loyalty and attractiveness for the new ones (Du and Vieira, 2012; Chen and Roberts, 2010).

Among the internal factors, we could consider the organization's resources. When a company decides to include an eco-efficient and sustainable growth in its processes it must own specific resources and capabilities. Improving the production in an environmentally sustainable way would mean, for example, decreasing the intensity of the use of raw materials and energy, promoting the recyclability of products that could generate a costs reduction in the long term (Sprinkle and Maines, 2010). In addition, a new theoretical insight considers the environment itself as a strategic resource for the firm (Flammer, 2013; Gibson, 2012).

Environmental sustainability should be improved within the value chain of the companies, to ensure a timely response to the interest of the community in ecology and environment. In fact, a sustainable environmental protection approach would allow companies to achieve a modern competitive advantage (Porter and Kramer, 2006) as they may boast the use of technologically innovative and more environmental respectful production processes that lead to an increase in profit.

Finally, and perhaps most importantly from a policy perspective, regulators (i.e., national and supranational, governmental and non governmental organizations) should provide for stringent enforcement mechanisms for companies that damage the environment and continue in their efforts to disseminate the principles of social and business sustainability, morally supporting and providing incentives for the development of environmental sustainable corporations.

\section{References}

1. Adam, A.M. and Rachman-Moore, D. (2004), "The Methods Used to Implement an Ethical Code of Conduct and Employee Attitudes", Journal of Business Ethics, Vol. 54 No. 3, pp. 225-244.

2. Adams, J.S., Tashchian, A. and Shore, T.H. (2001), "Codes of Ethics as Signals for Ethical Behavior", Journal of Business Ethics, Vol. 29 No. 3, pp. 199211.

3. Asgary, N. and Mitschow, M.C. (2002), "Toward a Model for International Business Ethics", Journal of Business Ethics, Vol. 36 No. 3, pp. 239-246.

4. Banerjee, S.B. and Bonnefous, A. (2011), "Stakeholder Management and Sustainability Strategies in the French Nuclear Industry", Business Strategy and the Environment, Vol. 20 No. 2, pp. 124-140.

5. Bernardi, R.A. and LaCross, C.C. (2009), "Positioning Codes of Ethics on International Corporations' Websites: A Six-Year Longitudinal Study", Advances in Accounting, Vol. 25 No. 1, pp. 75-80.

6. Blodgett, M.S., Dumas, C. and Zanzi, A. (2011), "Emerging Trends in Global Ethics: A Comparative Study of U.S. and International Family Business Values”, Journal of Business Ethics, Vol. 99 No. 1, pp. 29-38.

7. Carroll, A.B. (1979), “A Three Dimensional Conceptual Model of Corporate Social Performance", Academy of Management Review, Vol. 4 No. 4, pp. 497-505.

8. Castro, N. and Chousa, J. (2006), “An Integrated Framework for the Financial Fnalysis of Sustainability", Business Strategy and Environment, Vol. 15 No. 5, pp. 322-333.

9. Chen, J.C. and Roberts R.W. (2010), "Toward a More Coherent Understanding of the OrganizationSociety Relationship: A Theoretical Consideration for Social and Environmental Accounting Research", Journal of Business Ethics, Vol. 97, pp. 651-665.

10. Clark, M.A. and Leonard, S.L. (1998), "Can Corporate Codes of Ethics Influence Behavior?" Journal of Business Ethics, Vol. 17 No. 6, pp. 619630.

11. Clarkson, P.M., Li, Y., Richardson, G.D. and Vasvari, F.P. (2008), "Revisiting the Relation Between Environmental Performance and Environmental Disclosure: An Empirical Analysing”, Accounting Organizations and Society, Vol. 33, No. 4-5, pp. 303-327.

12. Collins, J.C. and Porras, J.L. (1995), "Building a Visionary Company", California Management Review, Vol. 37 No. 2, pp. 80-100. 
13. Collis, J. and Hussey, R. (2009), Business Research: A Practical Guide for Undergraduate and Postgraduate Students, Palgrave, Basingstoke.

14. Deegan, C. (2002), "Introduction - The Legitimizing Effect of Social and Environmental Disclosures - A Theoretical Foundation", Accounting, Auditing and Accountability Journal, Vol. 15 No. 3, pp. 282-311.

15. Dowling, J. and Pfeffer, J. (1975), "Organizational Legitimacy: Social Values and Organizational Behavior", Pacific Sociological Review, Vol. 18, pp. 122-136.

16. Du, S. and Vieira Jr., E.T. (2012), "Striving for Legitimacy Through Corporate Social Responsibility: Insights from Oil Companies", Journal of Business Ethics, Vol. 110 No. 4, pp. 413427.

17. Dumas, C. and Blodgett, M. (1999), “Articulating Values to Inform Decision-Making: Lessons from Family Firms Around the World", International Journal of Values-Based Management, Vol. 12 No. 3, pp. 209-221.

18. Erwin, P.M. (2011), "Corporate Codes of Conduct: The Effects of Code Content and Quality on Ethical Performance", Journal of Business Ethics, Vol. 99 No. 4, pp. 535-548.

19. European Commission (2001), Green paper, Promoting a European Framework for Corporate Social Responsibility, $\operatorname{COM}(2001) 366$ final, Brussels.

20. Farrel, B.J. and Cobbin, D.M. (2000), "A Content Analysis of Codes of Ethics from Fifty-Seven National Accounting Organizations”, Business Ethics: A European Review, Vol. 9 No. 3, pp. 180190.

21. Flammer, C. (2013), "Corporate Social Responsibility and Shareholder Reaction: The Environmental Awareness of Investors", Academy of Management Journal, Vol. 56 No. 3, pp. 758-781.

22. Flanagan, J. and Clarke, K. (2007), "Beyond a Code of Professional Ethics: A Holistic Model of Ethical Decision-making for Accountants", Abacus, Vol. 43 No. 4, pp. 488-518.

23. Freedman, M. and Jaggi, B. (2005), "Global Warming, Commitment to the Kyoto Protocol, and Accounting Disclosures by the Largest Global Public Firms from Polluting Industries", The International Journal of Accounting, Vol. 40 No. 3, pp. 215-232.

24. Friedman, M. (1970), "The Social Responsibility of Business Is to Increase its Profits", New York Times Magazine, September 13.

25. Gaumnitz, B.R. and Lere, J.C. (2002), "Contents of Codes of Ethics of Professional Business Organizations in the United States", Journal of Business Ethics, Vol. 35 No. 1, pp. 35-49.

26. Gaumnitz, B. and Lere, J. (2004), “A Classification Scheme for Codes of Business Ethics", Journal of Business Ethics, Vol. 49 No. 4, pp. 329-335.
27. Gibson, K. (2012), "Stakeholders and Sustainability: An Evolving Theory", Journal of Business Ethics, Vol. 109 No. 1, pp. 15-25.

28. Gordon, K. and Miyake, M. (2001), "Business Approaches to Combating Bribery: A Study of Codes of Conduct", Journal of Business Ethics, Vol. 34 No. 3, pp. 161-173.

29. Gray, R. (2010), “A Re-evaluation of Social, Environmental and Sustainability Accounting: An exploration of an Emerging Trans-disciplinary Field?" Sustainability Accounting, Management and Policy Journal, Vol. 1 No. 1, pp. 11-32.

30. Gray, R., Kouhy, R. and Lavers, S. (1995), "Corporate Social and Environmental Reporting: A Review of the Literature and a Longitudinal Study of UK Disclosure", Accounting, Auditing \& Accountability Journal, Vol. 8 No. 2, pp. 47-77.

31. Haxhi, I. and van Ees, H. (2010), "Explaining Diversity in the Worldwide Diffusion of Codes of Good Governance", Journal of International Business Studies, Vol. 41 No. 4, pp. 710-726.

32. Helin, S. and Sandström, J. (2007), "An Inquiry into the Study of Corporate Codes of Ethics", Journal of Business Ethics, Vol. 75 No. 3, pp. 253-271.

33. Helin, S., Jensen, T., Sandström, J. and Clegg, S. (2011), "On the Dark Side of Codes: Domination not Enlightenment", Scandinavian Journal of Management, Vol. 27 No. 1, pp. 24-33.

34. Holder-Webb, L.J., Cohen, J.R., Nath, L. and Wood, D. (2009), "The Supply of Corporate Social Responsibility Disclosures Among U.S. Firms", Journal of Business Ethics, Vol. 84, pp. 497-527.

35. Hubbard, G. (2011), "The Quality of the Sustainability Reports of Large International Companies: An Analysis", International Journal of Management, Vol. 28 No. 3, pp. 824-848.

36. Jensen, T., Sandström, J. and Helin, S. (2009), "Corporate Codes of Ethics and the Bending of Moral Space”, Organization, Vol. 16 No. 4, pp. 529545.

37. Kaptein, M. (2004), "Business Codes of Multinational Firms: What do they Say?" Journal of Business Ethics, Vol. 50 No. 1, pp. 13-31.

38. Kaptein, M. and Schwartz, M.S. (2008), "The Effectiveness of Business Codes: A Critical Examination of Existing Studies and the Development of an Integrated Research Model", Journal of Business Ethics, Vol. 77 No. 2, pp. 111127.

39. Kinchin, N. (2007), "More than Writing on a Wall: Evaluating the Role that Codes of Ethics Play in Securing Accountability of Public Sector DecisionMakers", The Australian Journal of Public Administration, Vol. 66 No. 1, pp. 112-120.

40. Kirkland, L. and Thompson, D. (1999), "Challenges in Designing, Implementing and Operating an Environmental Management System", Business 
Strategy and the Environment, Vol. 8 No. 2, pp. 128-143.

41. KPMG (2008), International Survey of Corporate Responsibility Reporting 2008, available on: http://www.kpmg.com/EU/en/Documents/KPMG_In ternational_survey_Corporate_responsibility_Survey _Reporting_2008.pdf.

42. Krippendorff, K. (1980), Content analysis: An introduction to its Methodology. Sage, New York, NY.

43. LaCross, C.C. and Bernardi, R.A. (2006), "Disclosures of Codes of Ethics on Corporate Websites: A Pre- and Post- Sarbanes-Oxley Longitudinal Study", Advances in International Accounting, Vol. 19, pp. 91-114.

44. Langlois, C.C. and Schlegelmilch, B.B. (1990), "Do Corporate Codes of Ethics Reflect National Character? Evidence from Europe and the United States", Journal of International Business Studies, Vol. 21 No. 4, pp. 519-536.

45. Lere, J.C. and Gaumnitz, B.R. (2003), “The Impact of Codes of Ethics on Decision Making: Some Insights from Information Economics", Journal of Business Ethics, Vol. 48 No. 4, pp. 365-379.

46. Lindblom, C.K. (1994), The Implications of Organizational Legitimacy for Corporate Social Performance and Disclosure, Critical Perspectives on Accounting Conference, New York, NY.

47. Lugli, E., Kocollari, U. and Nigrisoli, C. (2009), "The Codes of Ethics of S\&P/MIB Italian Companies: An Investigation of Their Contents and the Main Factors that Influence Their Adoption", Journal of Business Ethics, Vol. 84 No. 4, pp. 33-45.

48. McKinney, J.A., Emerson, T.L. and Neubert, M.J. (2010), "The Effects of Ethical Codes on Ethical Perceptions of Actions Toward Stakeholders", Journal of Business Ethics, Vol. 97 No. 4, pp. 505516.

49. Mittal, R.K., Sinha, N. and Singh, A. (2008), “An Analysis of Linkage Between Economic Value Added and Corporate Social Responsibility", Management Decision, Vol. 46 No. 9, pp. 14371443.

50. O’Dwyer, B. and Madden, G. (2006), "Ethical Codes of Conduct in Irish Companies: A Survey of Code Content and Enforcement Procedures", Journal of Business Ethics, Vol. 6 No. 3, pp. 217-236.

51. Orlitzky, M. and Benjamin, J.D. (2001), "Corporate Social Performance and Firm Risk: A Meta-Analytic Review", Business and Society, Vol. 40 No. 4, pp. 369-396.

52. Parker, L.D. (2011), "Twenty-one Years of Social and Environmental Accountability Research: A Coming of Age", Accounting Forum, Vol. 35 No. 1, pp. $1-10$.

53. Perrini, F. (2006), “The Practitioners' Perspective on Non-financial Reporting”, California Management Review, Vol. 48 No. 2, pp. 73-103.
54. Perrini, F., Russo, A. and Tencati, A. (2007), "CSR Strategies of SMEs and Large Firms Evidence from Italy”, Journal of Business Ethics, Vol. 74, No. 3, pp. 285-300.

55. Pfeffer, J. and Salancik, G. (1978), The External Control of Organizations: A Resource Dependence Perspective, Harper and Row, New York, NY.

56. Porter, M.E. and Kramer, M.R (2006), "Strategy and Society: The Link Between Competitive Advantage and Corporate Social Responsibility", Harvard Business Review, Vol. 80 No. 3, pp. 78-99.

57. Preston, A.M., Cooper, D.J., Scarbrough, D.P. and Chilton, R.C. (1995), "Changes in the Code of Ethics of the U.S. Accounting Profession, 1917 and 1988: The Continual Quest for Legitimation", Accounting, Organizations and Society, Vol. 20 No. 6, pp. 507-546.

58. Preuss, L. (2009), "Ethical Sourcing Codes of Large UK-based Corporations: Prevalence, Content, Limitation”, Journal of Business Ethics, Vol. 88 No. 4, pp. 735-747.

59. Schwartz, M.S. (2001), "The Nature of the Relationship Between Corporate Codes of Ethics and Behaviour", Journal of Business Ethics, Vol. 32 No. 3, pp. 247-262.

60. Schwartz, M.S. (2011), Corporate Social Responsibility: An Ethical Approach, Broadview Press, Peterborough, ON.

61. Shrivastava, P. (1995), "The Role of Corporations in Achieving Ecological Sustainability", Academy of Management Review, Vol. 20 No. 4, pp. 936-960.

62. Singh, J. (2006), "A Comparison of the Contents of the Codes of Ethics of Canada's Largest Corporations in 1992 and 2003", Journal of Business Ethics, Vol. 64 No. 1, pp. 17-29.

63. Singh, J. (2011), "Determinants of the Effectiveness of Corporate Codes of Ethics: An Empirical Study", Journal of Business Ethics, Vol. 101 No. 3, pp. 385395.

64. Singh, J., Carasco, E., Svensson, G., Wood, G. and Callaghan, M. (2005), "A Comparative Study of the Contents of Corporate Codes of Ethics in Australia, Canada and Sweden", Journal of World Business, Vol. 40 No. 1, pp. 91-109.

65. Sirgy, M.J., Siegel, P.H. and Johar, J.S. (2005), "Toward a Code of Ethics for Accounting Educators", Journal of Business Ethics, Vol. 61 No. 3, pp. 215-234.

66. Snell, R.S., Herndon, Jr. and Neil, C. (1999), “Codes of Ethics in Hong Kong: Their Adoption and Impact in the Run up to the 1997 Transition of Sovereignty to China", Journal of Business Ethics, Vol. 51 No. 1, pp. 75-89.

67. Sprinkle G.B. and Maines L.A. (2010), "The Benefits and Costs of Corporate Social Responsibility", Business Horizons, Vol. 53 No. 5, pp. 445-453. 
68. Stevens, B. (1994), "An Analysis of Corporate Ethical Code Studies: Where Do We Go From Here?" Journal of Business Ethics, Vol. 13 No. 1, pp. 63-69.

69. Stevens, B. (2008), "Corporate Ethical Codes: Effective Instruments for Influencing Behaviour", Journal of Business Ethics, Vol. 78 No. 4, pp. 601609.

70. Suchman, M.C. (1995), "Managing Legitimacy: Strategic and Institutional Approaches", Academy of Management Review, Vol. 20 No. 3, pp. 571-610.

71. Svensson, G., Wood, G., Singh J. and Callaghan M. (2009), "Implementation, Communication and Benefits of Corporate Codes of Ethics: An International and Longitudinal Approach for Australia, Canada and Sweden", Business Ethics: A European Review, Vol. 18 No. 4, pp. 389-407.

72. Trevino, L.K. and Nelson, K.A. (2010), Managing Business Ethics, Wiley, Hoboken, NJ.

73. Valentine, S. and Barnett, T. (2002), "Ethics Codes and Sales Professionals Perceptions of Their
Organizations Ethical Values", Journal of Business Ethics, Vol. 40 No. 3, pp. 191-200.

74. Valentine, S. and Johnson, A. (2005), "Codes of Ethics, Orientation Programs, and the Perceived Importance of Employee Incorruptibility", Journal of Business Ethics, Vol. 61 No. 1, pp. 45-53.

75. Van Tulder, R., Van Wijk, J. and Kolk, A. (2009), "From Chain Liability to Chain Responsibility", Journal of Business Ethics, Vol. 85, pp. 399-412.

76. Winkler, I. (2011), "The Representation of Social Actors in Corporate Codes of Ethics. How Code Language Positions Internal Actors", Journal of Business Ethics, Vol. 101 No. 4, pp. 653-665.

77. Woodward, D., Edwards, P. and Birkin, F. (2001), "Some Evidence on Executives' Views of Corporate Social Responsibility", British Accounting Review, Vol. 33 No. 3, pp. 357-97. 


\title{
ECONOMIC CRISIS IMPACT ON CORPORATE GOVERNANCE \& INTERNAL AUDIT: THE CASE OF GREECE
}

\author{
Michalis Bekiaris*, Thanasis Efthymiou**, Andreas G. Koutoupis***
}

\begin{abstract}
The 2007 was the year that the global economic crisis broke which resulted in the creation of a recession situation in almost the entire world. During this period, there were significant weaknesses in corporate governance, which refer to the practices followed by the board in risk management and shareholders' activism. The rapid growth in new products and changes in market structure can affect the development of processes and infrastructure of risk management. It is generally accepted that risk management, prevented businesses to fully identify the nature and severity of the recent economic crunch that the market faced. As the financial crisis is increasingly affecting the economic activities, the basic objective of internal audit directors is to find ways to add value to the business. The adoption of ERM should not be panacea for effective risk management, as well as empirical evidence suggests that the application does not indicate the existence of a protective shield. It should be noted that internal audit is a subset of risk management and may not have received the attention it deserved, despite the fact that the EPM is already running. Regarding the role of internal audit in the financial crisis, it needs to assess business activities, strategies, and thus the risk posed to business. Therefore, it should focus on issues such as the evaluation of existing business capabilities, collaboration with other risk and control functions, participation in meetings with major shareholders, assisting in business development for short-term strategies, etc. The purpose of this paper, is to record the current situation regarding the mode of interaction of the economic crisis in corporate governance and risk management. This is achieved by conducting research which underpins the distribution of structured questionnaires in Greeks professionals. In this way, it is presented a substantial imprinting of Greek views on a number of issues arising from the investigation of the above relation. In order to gather as much as possible essential information, it is performed a comparison of these global positions, by surveys carried out by the IIA, which had almost the same content. The conclusion is that the current economic conditions require a more effective form of corporate governance, while the three main weaknesses mentioned above are the areas that more focus should be given. Additionally, the most important factor that could highlight all risks in time is to perform audits on liquidity, capital and balance sheet consolidation. Still, there is a view that the ERM failed to recognize timely the danger of imminent economic crisis. Finally, budgets on internal audit have increased significantly, both in national and international level, while in the future the internal audit itself should have as a priority to consult the board, in order to identify, manage and monitor the key risks.
\end{abstract}

Keywords: Economic Crisis; Corporate Governance; Internal Audit; Greece

\footnotetext{
* University of The Aegean, 8 Michalon Street, Chios Island, 82100, Greece

E-mail: m.6ekiaris@aegean.gr

* University of The Aegean, 8 Michalon Street, Chios Island, 82100, Greece

E-mail: thanasis_efth@hotmail.com

स妨 University of The Aegean, 8 Michalon Street, Chios Island, 82100, Greece

E-mail: andreas.Koutoupis@mazars.gr, andreas_koutoupis@yahoo.gr
}

\section{Introduction}

The ninth of August 2007 marks the great outbreak of the financial crisis in the U.S.A. when an important part of the population could not meet loan obligations that originated from sub-primes (Poulter and Sims, 2007). The "bubble" in the real estate market in the U.S.A. which "popped" in 2007, caused the destruction of many financial institutions worldwide (Simkovic, 2009). A significant institution, BNP Paribas, deteriorated the situation due to the fact that that it ceased its activities regarding three hedge funds, specialized in mortgages in the U.S.A. (Elliott, 2011). The inability to collect accounts receivable of U.S.A. banks by borrowers of sub-primes, led to the defaulted obligations in coupons, values of bonds and CDOs in which many European banks had invested. The liquidity problem caused distrust in the payment in case of a bank would borrow from 
another, leading to increased interest rates in the interbank market. A possible application in case of a Greek bank borrowing from another one was both difficult and expensive, meanwhile this cost rolled over to customers, along with increases in Euribor (Poulter and Sims, 2007).

The initiate of reaching a solution came a year later when the U.S.A. government allowed the investment bank Lehman Brothers in bankruptcy. After its collapse, the idea that all banks were "quite big to fail" started to fade, as a result each bank was considered dangerous. Within one month, the threat of a domino effect of the global financial system caused the interference of Western governments by granting huge amounts of capital into banks to prevent their collapse. The banks were rescued in the ultimate moment, but it was too late to prevent the free fall that had already begun in the global economy.

Once the IMF and the European Union announced that they would provide financial assistance to Greece, the issue was no longer the solvency of banks but the solvency of governments. The budgets deficit were swelling during the recession, mainly not only as a result of lower tax revenues and rising welfare costs, but also because of the budgetary measures announced in the winter of 2008-09 (Elliott, 2011). Six years after the outbreak of the financial crisis, Greece has to address its own serious economic issues. At the end of 2009 the global economic crisis turned into European and, thus, Greek too; consequently, it intrigued the rating agencies and the markets in Greece's weaknesses and in the imperfections that the structure of the eurozone presents. In 2009 Greece stopped to enjoy low interest rates and high growth and entered the vicious cycle of high interest rates, loan denial and indefinite recession (Hardouvelis and Gortsos, 2011).

According to the literature review the root causes of the financial crisis are (Travlos, 2011): (1)the irrational use of securitized mortgage loans (Securitization), (2)excessive use of loans (Financial Leverage), (3)the incorrect classification of credit risk from relevant organizations (Bond Rating Agencies), (4)the non-effective remuneration system of the executives, (5)inadequate supervision of financial system and lack of transparency in the balance sheets and (6)finally the weak corporate governance in financial institutions.

The global financial crisis has exposed a number of 'concealed' economic conditions which are usually confined to the regulators and investors on Wall Street. These conditions are the basis of the effort to understand and resolve the economic crisis and contain: (1) the systemic risk, (2) the deleveraging, (3) the pre-cyclicality, (4) the preferred equity, (5) the Collateralized Debt bonds
(CDOs) and (6) the credit default exchange (CDS) (Nanto, 2009).

\section{The role of corporate governance in financial crisis}

The crisis in the market of sub-prime in the U.S.A. and the liquidity constraint had significant impact in many financial and banking institutions around the world. Interest on late payments on mortgage loans with higher than prime rate began to rise in the U.S.A. in 2006, when various consulting organizations began doubting about the future. In mid-2007, credit spreads began to rise and the international credit rating agencies announced the first significant declines as they began to excite the first doubts about the degree of risk in which many investors were exposed because of their investment. It is a fact that the boards of many financial institutions faced competitive conditions and permissive regulatory environment (OCED, 2009).

One of the major causes of the financial crisis, according to Professor Jang, is the failure of corporate governance. Transparency and accountability are the two basic principles of the CG were violated by the investment and commercial banks in the developed world, which resulted to the crisis. All risk management and financing mechanisms are founded without any regulatory mechanism. In fact, the current crisis and the Asian financial crisis of 1997 have a common failure cause of corporate governance. The core of the problem is a crisis of liquidity, not insolvency. All Asian economies have made significant progress in the CG after the crisis. However, this is limited mainly to the introduction of new rules and regulations, without particular attention to their application. For example, on a board of a company there are some independent directors but the critical factor is the influence they exercise (Jang, 2008).

A recent survey (Erkens et al., 2012) provides empirical evidence on how corporate governance affects the performance of financial institutions during the financial crisis. The current economic environment has special importance in the evaluation of corporate governance as well as indicates that business lack an effective corporate governance and mainly in financial institutions that comply with local regulations and corporate governance models as they characterized them as best practices (Moxey and Berendt, 2008). Another significant part of the survey mentioned, is that despite the fact that all businesses have been affected by the crisis, it was found that firms characterized by higher institutional ownership and more independent boards had worse stock performance indicators in relation to other companies. This is because (1) firms with higher institutional ownership took more risk before the crisis, which led to heavy losses for shareholders, 
and (2) firms with more independent board members raised more owners' equity during the crisis, which led to a transfer of wealth from existing shareholders to debt-holders. The results show us that corporate governance had a significant impact on business performance during the crisis by taking risks and financing policies (Erkens et al., 2012).

Fundamental role of the board is to provide the necessary guidance and carry out the necessary controls. Since the corporate scandals in the early 00's (Enron, WorldCom), revealed that the nonexecutive members did not report any significant manager's oversights. The recent economic events indicate that this happened in many financial institutions. This may be due to the complexity of the business. However, the answer to this problem is not the further education and in any case the regulatory provisions should not substitute the business judgment (Moxey and Berendt, 2008).

Therefore, the market today, according to current economic conditions, corporate governance requires to response in an effective way. For example, management should be clear about the strategy followed and its risk appetite, responding on time requiring effective reporting systems. The results of the crisis so far, indicate the existence of a number of weaknesses in factors that make an organization more effective. The way in which the implementation of risk management was decided in many cases was associated with the incentive system that prevailed in many businesses. It seems to have been, in many cases, a mistaken combination among the incentive system, risk management and internal control systems.

\section{The management of business risk and the financial crisis}

Over the last twenty years, the financial risk management has played an important role for companies and financial institutions. The current financial crisis has revealed significant weaknesses in risk management practices across the financial mainstream. The risk management is now seen as a core activity for all companies. Many of the catastrophic losses of the 1990s, such as the Orange County in 1994 and Barings in 1995 could have been avoided if the risk management practices were implemented (Voinea and Anton, 2009). According to a report conducted by the IIA, risks associated with the financial crisis can be categorized into: credit risks, risks of cost reduction, risks from the exposure to third parts, risks related to the company's reputation and liquidity risks (IIA, 2009).

The ERM triggered some companies, for example Alfac, Wells, Fargo, BB \& T, and JP Morgan, while in others it did not function effectively and thus they experienced the effects of the crisis (Aldhizer and Stone, 2009). In a survey conducted in 2008 by the economic magazine "Economist", 500 senior executives involved in risk management from the largest banks around the world, identified weaknesses in risk management that contributed to the current financial crisis (Voinea and Anton, 2009). Several theoretical and empirical studies showed limitations of risk management practices before and during the current financial crisis. Rene Stulz (2008) argued that there are five ways in which risk management systems cannot function effectively and they are verified by the current crisis. Specifically, these are: fail to use appropriate metrics for risk measurement, mistaken assessment of known risks, failure to take into account the known risks, failure to communicate the risks to the senior management, failure to monitor and manage risk.

The audit committee requires for more effective risk management, risk mitigation and inter-operational risk assessments. It seems that the internal audit is aware of these pressures and should not continue to provide a reasonable assurance for the activities of the board. According to a report conducted by the IIA one of the points of interest for risk management of the internal audit is to assess the skills and competencies of the audit. One of the challenges that the internal audit faces in an effort to broaden the scope of its issues related to risk management, is the perception, according to which risk management is outside the scope of the internal audit and not associated with its features.

As an organization's ability to manage risk increases, there should be a response from the internal audit so that these needs should be met. In today's business environment, internal auditors must be able to recognize and associate risks across all business functions. It is essential to be able to examine complex financial transactions and make presentations to the audit committee and the board. Once the business skills in risk management have reached a sufficient level of maturity, internal audit should be able to provide assurance to the business processes of ERM (IIA, 2009).

\section{Quantification of the interaction of the global economic crisis on the internal audit function}

As developments in the global economy are growing rapidly, the interest in recording and mapping the role of internal audit in the global economic crisis is becoming more and more intense. This is immediately apparent from a systematic effort for the quantification of this interest with the assistance of a series of surveys carried out. Their main research interest focus on a number of issues that study the existing interaction between the internal audit activity which was affected by the current economic developments. 
The IIA in an attempt to capture the impact of the economic crisis in the audit function conducted three different surveys ${ }^{4}$ with different sample periods. These surveys examine some important parameters that fall into five categories which are summarized below.

The number of staff employed by the department of internal audit: The highest rates appear in the category where the firm employs from 3 to 6 employees while there is a proportion of $36 \%$ of Fortune 500 companies stating that each of the companies belong to this category, the size of the internal audit department more than 30 people.

The impact of the economic crisis on the budget of internal control: As businesses operate in an uncertain and ever-changing environment, they have to face a number of risks. One of the first moves of companies is to make cutbacks in order to balance losses in a certain degree. There are a few times when the internal audit has been downgraded for his work, while there is the perception that it does not worth any money, or proposing the absorption by some other part of the business that will be responsible and deal with the procedures for internal control.

The majority of respondents say that the budget for the internal audit department remained at the same level, but on the other hand in many companies there were reductions of 10 to over $50 \%$. At the same time the years 2008-2010 there was a stable rate in all companies while there were marked some important percentages of business in which it increased in 2010 even before the crisis defused.

The role of risk management and internal control in the financial crisis: The main reason that shaped the financial situation of business today is the inefficient management practices relating to the risk management. According to the surveys, 33.4\% believe that better risk management practices could have been an omen of the global financial crisis for the company. Business risks may increase the risk of counterfeit issues in the financial statements. The $40 \%$ of respondents believe that the internal audit is thought to be a crucial in identifying and mapping the risks that arise due to the international economic circumstances. Moreover, according to the results, the risk management practices are still being developed but have received no official status $(36 \%)$. In addition, participants were asked to identify the level involved in risk management. Despite the fact that the results from two different

\footnotetext{
${ }^{4}$ Specifically the surveys are:

- Institute of Internal Auditors (2009): "Internal Auditing and Risk Management", Altamonte Springs

- Institute of Internal Auditors (2009): "The financial crisis and its impact on the Internal Audit Profession", Altamonte Springs

- Institute of Internal Auditors (2010): "Internal Auditing: Shifting Priorities for a Changing Environment", Altamonte Springs
}

questions confirm that the application of the processes of risk management is applied by the upper to the lower hierarchical levels, many companies have no official department in which these processes will be the primary object. Nevertheless, the existence of audit committee in a percentage of $11 \%$, suggests that risk management is a subject of interest for the senior management.

The essential assistance for the internal control seems to be the easiest identification of the major risks and their assessment and they are followed by: the participation in the identification of emerging risks, the provision of reassuring reports regarding the management of significant risks, assisting management on how the risk should be managed, providing assurance that risks are identified and there is a proper evaluation of the management procedures etc.

Participants were also asked on the criteria used in making assessments of risk. It is observed that the top positions with high rates are the impact and probability, followed by other effects such as the index of the effect to the client, the index ROI, the assemblage with other risks etc.

Despite the fact that risk management is a critical factor for both crisis prediction and its treatment, the auditors were asked to answer the question: Which the primary roles and responsibilities should be (beyond traditional standards) in the new continuously changing environment. The most important areas are: research for possible fraud $(65 \%)$, research on ethics $(42 \%)$, issues relating to compliance with the provision SOX (39\%) and, finally, risk management $(33 \%)$. An important point arising from these results is that actually, internal audit should strengthen its basic purpose, namely providing assurance and consulting, while at the same time it should apply business knowledge and skills in important audit operational initiatives relating to fraud and risk management.

The barriers that have been created for internal audit: The first survey gives more concrete actions on the obstacles facing the risk management that namely in descending order of frequency are: the view that board thinks that manage the risks effectively, firms characterized as decentralized do not apply effectively risk management across the enterprise, management has not hold anyone responsible for these issues, management ignores the positive cost-benefit ratio (due to different political areas their alignment is prevented), CAE has more limited presence than required, top management does not support adequately the overall design and finally, risk management is not an issue subjected to the internal audit when the latter has to deal with important issues. 


\section{Restructuring of Internal Audit in the future}

The role of Internal Audit may take several versions going from an independent assurance function in real management consultant. The future of Internal Audit should be based on a balance between these two roles, with respect to the expectations of stakeholders.

This role may increase in the next years as companies, beyond the financial pressures they face, they have to deal with a series of regulatorynormative pressures from governments in the form of regulatory measures against the economic crisis. The challenges the internal audit has to face are summarized as following (Kramer, 2009):

- Focus on internal control as risk-based, not only on trade.

- Curb on the analytical data and use of these data in the planning process in order to built controls which add real value to businesses.

- The internal auditors and firms should be characterized by a high degree of adaptability to the legal-regulatory environment.

- Ensuring that risk management and compliance is an integral part of the methodology used by the company as far as the risk is concerned.

- Another factor is the communication between internal audit and chief advisor and continuous communication between internal control and audit committee (where one exists).

- The existence of stability

- Internal auditors should think and operate more efficiently.
Deloitte conducted a survey on the evolution of internal audit in 2015 (Vandedooren and Bullens, 2010). One of the elements of the research is the size of the internal audit department in 2015. It is obvious that the auditors believe that the future size of the segment will grow significantly in the percentage of $60 \%$, while the size of the audit committee appears to be more sensitive to cost, as $54 \%$ believe that the size will remain the same. Nearly $50 \%$ of executive management believes that it will remain at the same level meanwhile the other half thinks its size will increase.

In the realm of professionals, research is ongoing to map the internal control in the future. Price Waterhouse Coopers (2007) presented a new proposal on the future of the function of internal audit. The new value proposition should include the provision of assurance on risk management in conjunction with the traditional responsibility to ensure all controls. Increasing the scope of risk management inevitably internal audit function will be aligned on operational risk management functions regardless of their level of maturity. In this way, the traditional method of managing risks is part of the past by giving each position to a more risk-centric philosophy.

This philosophy means that internal auditors should adopt a complete conceptual approach to audit, risk assessment, risk management, and everything that extends beyond a narrow focus on simple tests. With such a philosophy, internal auditors will increase their functional values at a time when the valuation and risk management have become the key concerns of interested parts. Based on the survey results the value of internal control depends on two key factors: the nature of the initial focus of internal control and the degree of maturity of the processes of risk management that it serves. These correlations demonstrated in Figure 1.

Figure 1. The added value model 2012 of internal audit, source: PwC

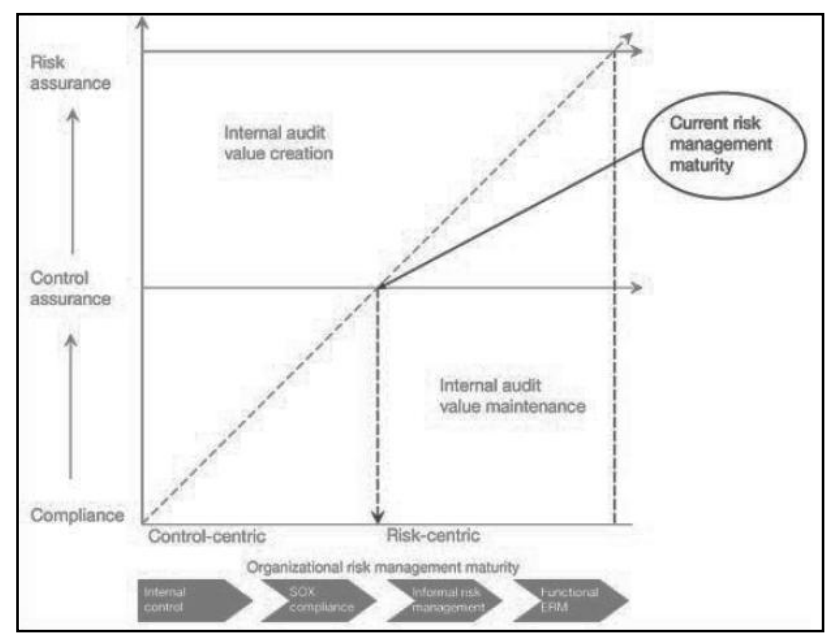




\section{Economic crisis and internal control: Lessons and Opportunities}

In a broader effort to understand the financial crisis, it is easy to attribute responsibilities to external financial and economic factors as they are raised and studied more widely. However, the external factors are only the visible part of the failure of internal corporate governance. Therefore, the first important lesson arising from the financial crisis for internal control is the significant deficiency in corporate governance, risk management processes and internal control many weak companies had to deal with (Millichip, 2010). In summary, the following table presents the main lessons drawn from the financial crisis and the appropriate actions for the internal auditors.

Table 1. Courses for internal auditors arising from the crisis, source IIA

\begin{tabular}{|l|l|}
\hline Courses for internal auditors & Actions of Internal Auditors \\
\hline $\begin{array}{l}\text { The businesses failed due to insufficient internal } \\
\text { governance }\end{array}$ & $\begin{array}{l}\text { Control whether adequate procedures in corporate } \\
\text { governance, risk management and internal controls } \\
\text { are in place }\end{array}$ \\
\hline $\begin{array}{l}\text { Failures in governance is usually unintentional } \\
\text { consequence of other activities }\end{array}$ & $\begin{array}{l}\text { Considering unintended consequences as part of the } \\
\text { daily operating control }\end{array}$ \\
\hline $\begin{array}{l}\text { The failures of governance, come from exploitation } \\
\text { opportunities that involve large amounts of audit risk }\end{array}$ & $\begin{array}{l}\text { Control in any activity for hidden influences, is there } \\
\text { a risk that has not been calculated? }\end{array}$ \\
\hline $\begin{array}{l}\text { Companies do not learn from the mistakes of other } \\
\text { enterprises }\end{array}$ & $\begin{array}{l}\text { Stay Informed of the actions of competitors. } \\
\text { Exploiting positive points-Avoid negative ones }\end{array}$ \\
\hline Failures in governance are inevitable & The goal is rationality and not absolute assurance \\
\hline $\begin{array}{l}\text { The failures come from people not from the } \\
\text { procedures }\end{array}$ & $\begin{array}{l}\text { Control of human recourses, there is adequate control } \\
\text { for the work undertaken }\end{array}$ \\
\hline $\begin{array}{l}\text { Companies are less reactive rather than they should } \\
\text { be in identifying failures in governance }\end{array}$ & $\begin{array}{l}\text { Attention to signs of emerging risks and focus on } \\
\text { their reactive limitation }\end{array}$ \\
\hline
\end{tabular}

An important opportunity that emerges from the financial crisis is creating a world-scale reflection of the internal auditors, as well as an important source of feedback to correct major weaknesses in both corporate governance and risk management system with a view to avoiding such significant failures in the future (Millichip, 2010).

\section{Research methodology}

Aim of the research: The objective of the survey is recording the Greek reality regarding the interaction of (1) corporate governance, (2) internal control and (3) the risk management to the global economic crisis. Moreover, a discovery of common-place items of professionals at local and international level is pursued. Through analysis of the facts proposals for the future development of the internal audit function are presented.

The research method used is the questionnaire, containing 28 questions. The questions were of three kinds:

- Sealed (Yes / No or increase / decrease)

- Multiple choice questions

- Questions with rating scale of 1 to 5 (Likert scale). According to this scale, 1 indicates the lowest level of satisfaction while 5 the highest.

As far as the analysis of the research is concerned, descriptive statistics was used (eg frequency tables), tabulation and statistical techniques based on the chi-squared control.

\section{The Sample}

For the formulation of safer and effective results, it was crucial that the sample consists of professionals subject to audit. Given the difficulty in finding such a qualified sample, two tactics were followed. Initially, there was an invitation email to staff auditors. But because of limited access to e-mail by many internal auditors and since it has not yielded adequate results, an alternative method was preferred.

The process by which data and most answers were collected involves a widely known professionals networking site. The population of the study was 85 internal auditors who operate in many sectors of the Greek economy. Out of the 85, 40 were successfully updated, while 28 replied. The remaining 5 come from the first procedure. Therefore, the participation rate in the survey was $70 \%$.

Participants were men and women of internal auditors, of all ages. All respondents regardless of gender are above 30 years. The $55 \%$ of the sample were men between 30 and 40 years, while women have relatively low participation rate of any age.

The largest part of the sample has professional experience in the field of internal audit at least 6 
years. This fact leads to conclude that the answers received are based on people who have a close relationship with matters relating to audit.

Most companies and $42 \%$ are active in the Greek economy from 10 to 20 years. Equally important is the percentage of firms operating above 31 years $(29 \%)$.

The internal auditors, who participated, work in companies belonging to different industries. More specifically, most companies are in the banking industry. This is quite useful, as in many parts of the paper attitudes and reactions of financial institutions were discussed, as it is worth mentioned that they all have internal audit department.

Regarding the size of the internal audit department, the firms that have an internal auditor constitute of $27 \%$ of the sample. Firms staffed with 2 to 3 internal auditors are the $18 \%$ of the sample. The rate for businesses whose internal audit department consists of 4 to 6 people is identical to that of the companies whose internal audit department has more than 6 people, and is $27 \%$.

Regarding the hierarchical dependence of internal audit director in the business the higher figure represents the audit committee, i.e. the internal auditor is directly referring to it, with $63 \%$, the Board is following with $18 \%$, the CEO with $12 \%$ and finally the president with $6 \%$.

\section{What research learnt us: Corporate governance and financial crisis}

Respondents, in a vast majority, agree with the view that the current economic conditions require a more effective form of corporate governance. This view is in complete agreement with the theoretical approach of the correlation between economic crisis and corporate governance. For this reason, from now on, the government should be clear on the strategy followed and determine from the beginning the risk appetite, responding on time, requiring efficient reporting systems. Also, businesses should have as a key concern the supervision of their efficient function and their compatibility with the business targets and the risk appetite.

Moreover, the empirical results on the wrong connection of the three factors leading to ineffective corporate governance seems to fully support the theoretical approach to incorrect connection, i.e. to associate risk management with incentive schemes and systems of internal control. Furthermore, all Asian economies after the crisis of 1997 made significant progress in the CG.

In the banking sector, there were companies that failed to fully identify the severity and nature of the recent pressure accepted by the market. However, there were bank institutions that were able to cope with these pressures. For the respondents, there were four important factors placed, and they were asked to evaluate the most important factor that would work positively for the business and bring in time all the risks. In the first place of importance was to conduct audits on liquidity-capital consolidation balance sheets. This factor, according to the literature was the one that were applied yielded positive results, and helped the company to develop on time sources of significant hazards. According to recent literature, two of the key areas where corporate governance showed significant weaknesses, so it cannot successfully meet its mission, are the remuneration processes and the behavior of shareholders.

Respondents were asked to give their opinion on the two dimensions. Regarding the procedures and specifically reward bonuses, theoretical approach considers as a failure of corporate governance, because they somehow encouraged pay schemes to take excessive and dangerous levels of risk. Practically, however, this is not imprinted is this research. So, it is observed that there is a common consensus between theory and practice and the degree of significance of this factor from the survey sample was relatively low.

As for the other factor, the fact is that many people who claim that there is no correlation between the size of the shareholders and their behavior during the process of the enactment of important issues, from the beginning of the economic crisis and many companies, a number of important decisions were taken by a few percentages of the shareholders. The sample also moved towards the same direction. This factor was welcomed with neutrality, which suggests that perhaps for them it is not so significant barrier to effective corporate governance behavior of shareholders.

\section{What research learnt us: Internal audit, ERM and global financial crisis}

In the second part of the analysis, and more specifically in the relationship between the business risk management and the economic crisis, the theoretical approach supports that the ERM failed to recognize on time the danger of the coming economic crisis citing as an example the companies Fannie Mae \& Freddie Mac Failures where the mere existence of a CAE, reassured that management has in place a comprehensive risk management program, and the paradox is that he did not exploit the information that even this sole director gave. The findings regarding this piece indicate an agreement degree on this conception, so we have a certain harmony of views between theory and practice in this area.

Another issue that was raised is whether the effective communication between the audit committee and management could highlight all the dangers on time, so that the company could avoid 
the consequences of the economic crisis. The theoretical approach supports the existence of communication in highlighting risks. A typical example is JP Morgan, where the audit committee of the company held regular meetings with the financial director. The company's dedication to addressing the risk, allowed it to acquire Bear Stearns and Washington Mutual. The audit committee of the company believes that most committees in the various businesses have an overrated view of management thinking that has complete knowledge about the business risks. The audit committee should adopt a new view which not only shows the confidence in management but also makes verification activities when assessing the knowledge of the management across the business risks. The results of research, on the other hand, show a neutrality in the field of communication, which makes it hard work to draw reliable conclusions.

There are many suggestions for the role that internal control should have against the ERM. In the literature review we found plenty of suggestions on how we could improve the ERM. Some of them were assisting the management and the audit committee, assuring that management has set the minimum acceptable level of risk, etc. The research results come in complete identification with the theoretical approach, as well as the internal auditors of the sample believe strongly that the internal audit can improve the functioning of ERM.

\section{What research learnt us: Comparative analysis research}

The purpose of the next section was the comparative analysis of some studies conducted abroad with the Greek reality in a number of different issues. Initially the expenditure profile of the company was examined with respect to internal control in the period of crisis. An interesting result has come after this comparison. Once in the rest of the world in the last 2 years, the costs related to the internal audit activity grew at $9 \%$, in Greece, those who answered that in recent years the company has increased spending was $25 \%$, almost the double. Deloitte, conducted a survey on the evolution of internal audit in 2015 One of the factors considered by the research is the size of the internal audit department in 2015. This does not seem to be very realistic and in line with the current data that surveys record.

Even a comparison of "domestic" and international opinion is the view that the main reason that determined the economic situation of businesses today are ineffective management practices relating to the operation of risk management. In Greek reality, this view was rated high in level of agreement from respondents. In short, that the percentage of those who share this view is important. On the other hand, in a study by the Institute, over $50 \%$ of respondents said they disagreed with this view and an approximately $20 \%$ held a neutral attitude.

When asked for a formal risk management program, the Greek companies had relatively low average of application, with the exception of the banking industry and the service sector that showed a relatively high score. The responses from the surveys in the respective foreign matter are that a significant proportion of firms $(36 \%)$ had informal risk management program, while firms with a formal program were also somewhere on the same level $(31 \%)$.

Regarding the role of internal audit in risk management our research highlighted as important the role of participation in the identification and assessment of critical risks. Instead, the Institute's studies highlighted the most important role of internal audit, the involvement in the effort to highlight the risks.

In the question of which should be the primary role of Internal Audit in the current environment views are diametrically opposed in comparison with the researches. The research of the Institute demonstrates as primary role the investigation of fraud, followed by research on ethical issues, then issues relating to risk management and finally issues related to regulatory compliance. While the research conducted in this paper, marks as primary role issues related to risk management, following by the investigation of fraud, then the research on ethical issues and end on regulatory compliance. The most important area in which Internal Audit should focus, is to assist the authorities in order to identify, manage and monitor the key risks. This view has wide acceptance by both surveys of the Institute and the investigation of this paper.

When asked what type of risk is estimated to be inextricably linked to the economic crisis and control should focus, there were significant differences in the responses. While in this research important category was the liquidity risk, in the research of the institute were the risks arising from exposure of the company to third parts. Nevertheless, the second largest category in both surveys was credit risks.

\section{What research learnt us: The future development of the internal audit}

Regarding the future development of the internal audit function, the literature involves much discussion about a strategic focus on risk. Greek internal auditors were also asked to evaluate this variable, and seem to agree to a large extend with this view. Therefore the studies made for the future dimension of the internal control and want it to pass in a risk-centric approach things have an actual base. 
Typical example is the proposal of $\mathrm{PwC}$ where: The new value proposition should include the provision of assurance on risk management in conjunction with traditional responsibility to ensure all checks. Increasing the scope of risk management inevitably the internal audit function will be aligned with the operational risk management functions regardless of their level of maturity. In this way, the traditional way of managing risks is part of the past by giving its position to a more risk-centric philosophy. This philosophy means that internal auditors should adopt a complete conceptual approach to audit, risk assessment, risk management, and everything that extends beyond a narrow focus on simple tests.

\section{Conclusions}

The market today, according to current economic conditions, requires corporate governance to perform effectively as much as possible. Besides, one of the major causes of the financial crisis is the failure in corporate governance. Regarding the banking sector, there is a matter of morality for management to ensure that the borrowing or the actions of the mediators will not reduce the value of the business. In this effort, the important role of government is to provide the necessary guidance and carry out the necessary controls. It is argued that nowadays the top management tries to limit as much as possible the impact of the economic crisis within a business.

In recent years, enterprise risk management has played an important role for companies and financial institutions. As the economic crisis is increasingly affecting the economic activities, the main focus of many internal audit directors is to find ways to add value to their businesses.

Despite the fact that financial institutions and the insurance industry had the highest rates of adoption of the framework COSO ERM, these two sectors received the greatest negative impact of the global economic crisis. Inefficiencies of ERM can lead to: recognition and risk assessment, barriers for a full installation, measures to address the risk and the type of reports.

The role of the internal auditor can be enhanced by the economic crisis by promoting the creation of integrated business risk management processes or increasing the existing processes across the enterprise. The data which the internal audit should use that result from the economic crisis include: the assessment of capabilities of the company, collaboration with other risk and control functions, participation in meetings with major shareholders, strengthen the communication, evaluation of controls and meanwhile keep pace with evolving practices.
The current challenges faced by the internal audit concern not only in the scope, but also in the ways that auditors carry out the activities.

In the context of ever increased reductions in their spending in order to survive, there is the perception that internal control is considered as a needless expense. The reductions should be cautious and should be compensated if the cost of the expense is greater than the benefit provided by the internal audit in time.

It is a fact that the main reason that shaped the financial situation of enterprises today is the inefficient management practices related to the risk management. Risk management practices are still being developed without have received an official status in most businesses, meanwhile the companies which have a formal risk management program in place are few.

Auditors have to deal with many challenges such as: the focus on risk-based-internal-audit, the usage of the data in order to construct controls which add real value to businesses, the adoption of a high degree of adaptability to the legal-regulatory environment as an increase regarding the quality of communication.

The added value that the internal control will provide in the future will be determined largely by the influence of the same function in the business, which is reflected in the importance of the presentation of audit results.

It is stated that most businesses consider risk management as a fundamental process for the operational functions. This means that the risk and its control are no longer technical aspects of the internal audit function or other activities. On the other hand, the management has begun to take responsibility for the risks it faces and ensure the effectiveness of the controls to limit them.

The future internal audit model activity should include the provision of assurance on risk management in conjunction with traditional responsibility to ensure all controls.

Given the empirical evidence, current economic conditions require a more effective form of corporate governance. Regarding the internal control the important role in its participation in the effort to predict the economic crisis is the identification and assessment of critical risks. At the same time ERM failed to timely recognize the danger of the coming economic crisis. In addition, effective communication between the audit committee and management could highlight all risks promptly, so that the company could avoid the consequences of the economic crisis.

The primary role of Internal Audit in the current environment is researching for possible frauds and dealing with issues related to risk management. Regarding the future development of the internal audit function, the surveys conducted 
lead to to the conclusion that internal audit should turn into a risk-centric approach.

\section{References}

1. David H. Erkens, Mingyi Hung, Pedro Matos (2012): "Corporate governance in the 2007-2008 financial crisis: Evidence from financial institutions worldwide", Journal of Corporate Finance, Vo. 18.

2. Dick Nanto (2009): "The Global Financial Crisis: Analysis and Policy Implications, Congressional Research Service", CRS Report for Congress.

3. George Aldhizer and Mark Stone (2009): "Knowledge briefing: The impact of the current financial crisis on the global business community", Global Audit Information (GAIN), The Institute of the Internal Auditors, Altamonte Springs.

4. Gheorghe Voinea, Sorin Gabriel Anton (2009): "Lessons from the current Financial Crisis. A Risk Management Approach", Review of Economic and Business Studies Volume 2009, No 3.

5. Gikas Hardouvelis Gortsos and Chris (2011), "The international crisis, the crisis in the eurozone and the Greek financial system," Greek Union Bank.

6. Hasung Jang, Dean (2008), Failure of corporate governance has led to the global economic crisis, available on line: http://www.indianexpress.com/news/failure-ofcorporate-governance-has-led-to-the-globaleconomic-crisis/401099/1.

7. Institute of Internal Auditors (2009): "Internal Auditing and Risk Management", Altamonte Springs.

8. Institute of Internal Auditors (2009): "The financial crisis and its impact on the Internal Audit Profession", Altamonte Springs.

9. Institute of Internal Auditors (2010): "Internal Auditing: Shifting Priorities for a Changing Environment", Altamonte Springs.

10. Institute of Internal Auditors, 2009, Knowledge Alert, Internal Auditing and Risk Management, Altamonte Spring.

11. Institute of Internal Auditors (2009), "A World in Economic Crisis: Key Themes for Refocusing Internal Audit Strategy", Altamonte Springs.

12. Institute of Internal auditors (2009): "Knowledge Alert: What's next for Internal Auditing: Expanding the Focus to Address Emerging Risks", Altamonte Springs.

13. Larry Elliott (2011): "Global financial crisis: five key stages 2007-2011", available on line: http://www.guardian.co.uk/business/2011/aug/07/gl

obal-financial-crisis-key-stages (Accessed 10/12/11).

14. Laurent Vandedooren and Joris Bullens (2010): "The changing role of Internal Audit", Deloitte

15. Michael Simkovic (2009): "Secret Liens and the Financial Crisis of 2008", American Bankruptsy Law Journal Vol.83.

16. Michael Simkovic Competition and Crisis in Motgage Securitization", Indiana Law Journal, Vol. 88.

17. OECD. "Principles of Corporate Governance", 2004, Paris, OECD.

18. O’Donnell E. (2005) "Enterprise Risk Management: A system-thinking framework for the event identification phase", International Journal of Accounting Information systems, Vol. 6.

19. Paul Moxey and Adrian Berendt (2008): "Corporate Governance and the Credit Crunch", Discussion paper, ACCA.

20. Philippe Haspeslagh (2010): "Corporate governance and the current crisis", Corporate Governance Vol.10 No.6.

21. Price Waterhouse Coopers (2007) "Internal Audit 2012 A study examining the future of internal auditing and the potential decline of a controlscentric approach".

22. Richard Millichip (2010): "Internal Auditing: A New Direction in the Wake of the Financial Crisis", The Institute of Internal Auditors Research Foundation.

23. Sean Poulter and Paul Sims (2007): "Police called to break-up Northern Rock panic queues as customers withdraw millions" Available on line http://www.dailymail.co.uk/news/article481778/Police-called-break-Northern-Rock-panicqueues-customers-withdraw-millions.html.

24. Stulz, Rene (2008), "Risk Management Failures: What Are They and When Do They Happen?", Journal of Applied Corporate Finance, Vol. 20, No.4

25. The Auditing Practices Board (2008): "Audit issues when financial market conditions are difficult and credit facilities may be restricted", FRC Publications

26. Travlos Nicholas (2011), "Corporate Governance before and after the crisis", Collective Volume of GREEK UNION BANK "The international crisis, the crisis in the eurozone and the Greek financial system'. 


\title{
РАЗДЕЛ 2 \\ КОРПОРАТИВНОЕ УПРАВЛЕНИЕ И СОВЕТ ДИРЕКТОРОВ
}

\section{SECTION 2 CORPORATE GOVERNANCE AND BOARD ISSUES}

\section{RELATIONSHIP BETWEEN BOARD INDEPENDENCE AND FIRM PERFORMANCE POST-SARBANES OXLEY}

\author{
Kiridaran Kanagaretnam*, Gerald J. Lobo ${ }^{* *}$, Dennis J. Whalen***
}

\begin{abstract}
We examine the relationship between board independence and firm performance over multiple years, post-Sarbanes Oxley. The enactment of the Sarbanes-Oxley Act (SOX) in July, 2002 coincided with the NYSE/NASDAQ proposals to alter their standards for listed companies. These changes included a requirement that boards be comprised of a majority of independent directors and tightened the criteria for a director to be considered "independent". We hypothesize and find that the passage of SOX, together with the new NYSE/NASDAQ regulations, result in independent directors who are more effective monitors of management, leading to stronger firm performance. Our results should bolster investor confidence in the financial markets at a time when the NYSE/NASDAQ has strengthened the corporate governance standards for listed companies.
\end{abstract}

Keywords: Board Independence, Firm Performance, Sarbanes-Oxley Act

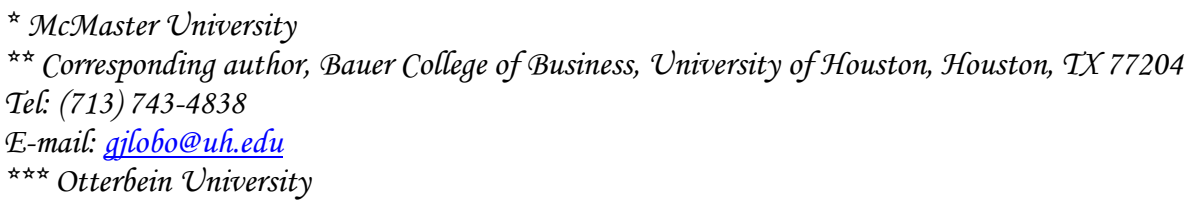

\section{Introduction}

The recent corporate scandals at Enron, Tyco, and WorldCom demonstrate that management will sometimes engage in unethical conduct for personal gain, to the detriment of their stockholders. This has led to a renewed focus on the importance of corporate governance in today's society. Corporate governance encompasses the controls and procedures that exist to ensure that management acts in the interests of shareholders, and thereby maximizes the value of the firm. Legislators, in an attempt to prevent future scandals, passed the Sarbanes-Oxley Act (SOX) in July, 2002, which mandates, among other things, that executives attest to the accuracy of corporate financial statements and that corporations disclose whether or not they have a code of ethics for senior financial management. In addition, at this time, both the NYSE (Rule 303A) and NASDAQ (Amendment to Rules 4200 and 4350) proposed, and later adopted, stricter guidelines for a director to be considered "independent."

We examine the relationship between board independence and various measures of corporate performance during the post-SOX period. Our study, like that of Larcker et al. (2007), utilizes an exploratory approach given that no theory exists to rigorously define the relationship between board 
independence and firm performance. While several recent studies also investigate how different aspects of corporate governance relate to firm performance, the results of that research are mixed. We argue that the link between board independence and firm performance has strengthened since the passage of SOX and the adoption of the NYSE/NASDAQ proposals for several reasons.

First, the post-SOX environment is a particularly good one for studying the relationship between board independence and firm performance because the revised NYSE/NASDAQ listing requirements tightened the criteria for a director to be considered "independent". The typical board of directors is comprised of both insiders (i.e., company employees) and outsiders (i.e., directors who are unrelated to the company other than being board members). The loyalty an inside director has toward management may compel her/him to overlook fraudulent activity, in an extreme case, or merely to support an ineffective management team. Morck (2004, pg. 3) states that (referring to the Milgram (1974) experiments) "a human subject suppresses internal ethical standards surprisingly readily when they conflict with loyalty to an authority figure. This accords well with officers and directors' stalwart loyalty to misguided CEOs, even under clear signs of impending financial doom." Previous studies conducted in the pre-SOX period (e.g., Molz, 1988, Bhaghat and Black, 2002) have been unable to find any link between board independence and firm performance, possibly due to the "pseudo" independence of these directors. An independent director in the post-SOX period should have no loyalty to management and should, therefore, fulfill her/his fiduciary duty to shareholders by monitoring management to ensure that shareholder wealth is maximized.

Second, corporate executives as well as directors are now being held more accountable for their actions. Indeed, outside directors at both Enron and WorldCom were found to be liable in multi-million dollar class action lawsuits. Klausner et al. (2005) suggest that "the WorldCom and Enron settlements will increase liability fears among outside directors." This should compel those directors to scrutinize management actions more closely.

Third, the typical board member now holds fewer directorships and the percentage of directors who are retired has increased (Chhaochharia and Grinstein, 2007). This should provide directors with additional time to perform their duties and enable them to monitor management more effectively (Fich and Shivdasani, 2006).

Our study employs three corporate performance measures - buy-and-hold equity returns, return on assets, and Tobin's Q. We utilize five variables to capture various dimensions of board independence, including board leadership, and three additional corporate governance variables as control variables. The board independence variables include the percentage of independent directors on the board $(P C T O N B D)$, and the percentage stock holdings of officers and directors (DOHOLDINGS). In addition, we use indicator variables to denote the existence of a separate chair for the board of directors (SEPCHR), whether there is a lead director (LEADDIR), and whether the CEO has any relatives on the board (REL). Our governance control variables include indicator variables to denote whether a firm has an optimal board size of four to seven members $(B D S I Z E)$ and an optimal board meeting frequency of four to twelve per fiscal year (NUMMTGS). As an additional governance control variable, we use the fraction of CEO compensation that is comprised of stock options and restricted stock (COMPMIX).

We use principal components analysis to group the eight board variables into four composite factors board independence $(F B I)$, board leadership $(F B L)$, board size $(F B S)$, and other $(F O T H)$ - based on the characteristics of the individual corporate governance variables that are related to each factor. We then utilize ordinary least squares regression to relate both the board independence factors and the individual board variables to each of our performance measures for the post-SOX period (i.e., 2002-2005) while controlling for a firm's capital structure and other variables associated with firm performance.

Our results indicate that the board independence factor $(F B I)$ is significantly positively related to future equity returns. The board leadership factor $(F B L)$, the board size factor $(F B S)$, and the "other" board factor $(F O T H)$ each have a significant positive relationship with future ROA and Tobin's Q. In addition, the individual governance variables generally exhibit the predicted relationships with future firm performance, demonstrating that more independent boards are more effective monitors of management.

Our results demonstrate that independent directors are fulfilling their fiduciary duty to shareholders by effectively monitoring management in the post-SOX period. This finding also has important implications for investors and regulators. Both groups should welcome these results, particularly since the percentage of independent directors on the typical board has increased. Investors can take comfort in knowing that independent directors are now truly "independent". In addition, our findings reinforce the recently adopted NYSE/NASDAQ corporate governance rules, requiring that each listed company has a majority of independent directors.

The remaining sections of the paper are organized as follows. First, the research background on board independence and firm performance is presented. Next, we describe the data and sample selection, followed by the empirical analysis. The final section provides the conclusion. 


\section{Research Background on Board Independence and Firm Performance}

Studies which examine the relationship between board independence and corporate performance generally yield inconsistent results. One line of reasoning suggests that the presence of independent directors on the board should enhance corporate performance. Since they have no links to current management, independent directors should not be biased toward management in their decision-making, suggesting that they are better able to monitor management and ensure that management acts in the interest of shareholders by maximizing firm value.

Baysinger and Butler (1985) find a positive relationship between the percentage of independent directors on the board and subsequent (i.e., ten years later) return on equity. Larcker et al. (2007) demonstrate, using only one year of data (i.e., June, 2002 through May, 2003), that there is a negative relationship between future stock returns and their "Insider Power" factor. One component of this factor is a variable that represents the percentage of inside directors on the board. Lefort and Urzua (2008) find a positive relationship between the percentage of independent directors on the board and Tobin's Q for a sample of Chilean firms.

Other factors also suggest that the presence of independent outside directors on the board should strengthen company results. For example, Weisbach (1988) reports that companies with a higher percentage of outside directors are more likely to replace a chief executive officer if the firm performs poorly. Rosenstein and Wyatt (1990) demonstrate that the appointment of an outside director to the board is accompanied by a positive stock price reaction. Klein (2002) finds that firms with a greater percentage of outside directors on the board are less likely to manage earnings (as measured by abnormal accruals). Bhagat and Black (2002) report that less profitable firms strive to make their boards of directors more independent. Walters et al. (2007) find that shareholder returns around acquisition announcements are positively related to the percentage of independent outside directors on the board when CEO tenure lengthens. Le et al. (2006) demonstrate that the strength of the relationship between research and development spending and firm performance is influenced by independent outside board members.

However, it is also possible that the presence of independent outside directors on the board could adversely affect firm performance. Independent directors may not have detailed knowledge and sufficient expertise about company operations to be effective monitors of management. Fama and Jensen (1983) recognize that outside directors enhance the monitoring ability of corporate boards but also emphasize that insiders are a valuable source of information. Indeed, Byrd and Hickman (1992) demonstrate that the presence of independent directors on the board can reduce shareholder wealth. They find a nonlinear relation between the percentage of independent directors on the board and abnormal equity returns when firms make tender offer bids. Firms with boards comprised of 40-60 percent of outside directors have higher returns while firms with boards comprised of more than 60 percent of outside directors have lower returns. Agrawal and Knoeber (1996) observe a significant negative relationship between the percentage of outside directors on the board and firm performance (as measured by Tobin's Q). Vance (1978) demonstrates that firms whose boards are controlled by management perform better than those whose boards are controlled by outsiders. However, Bhagat and Black (2002) do not find (using several metrics of performance) that firms with more independent boards perform better than those with less independent boards. Molz (1988) also does not find that outside directors enhance financial performance.

The results of these studies indicate that it is not clear whether independent directors contribute to or undermine firm performance. This suggests that an investigation of the relationships between key variables that proxy for board independence and firm performance over multiple years, post-SOX, is an important addition to the current literature on corporate governance. In particular, if SOX and the recently adopted NYSE/NASDAQ corporate governance rules have actually bolstered the quality and responsibility of independent directors, then we would see a positive relation between proxies for board independence and firm performance in the postSOX period.

\section{Methodology, Sample Selection, Data and Variable Definitions}

The data on board quality are obtained from the Investor Responsibility Research Center (IRRC) database for board practices for the years 2002-2005. The IRRC database covers firms that have their annual general meeting during the first seven months of the year. The data are based on the firms' proxy statements filed with the SEC. Merging the IRRC database with COMPUSTAT and CRSP gives us samples of 3,008 and 2,854 firm-year observations with all required variables for tests of firm performance based on ROA and stock returns, respectively.

We estimate the following simple regressions of firm performance and board independence using ordinary least squares (hereafter, OLS). The first regression (equation 1) employs the individual governance variables as regressors, while the second regression (equation 2) utilizes the governance factors as regressors. We estimate these regression equations using 2002-2005 data from the post-SOX period. 


$$
\begin{gathered}
\text { Firm performance }=a+\Sigma b^{*} \text { Individual } \\
\text { Governance Variables }+c^{*} \text { Capital } \\
\text { Structure }+\Sigma d^{*} \text { Control Variables }+e
\end{gathered}
$$

$$
\begin{gathered}
\text { Firm performance }=a+\sum b^{*} \text { Governance } \\
\text { Factors }+c^{*} \text { Capital Structure }+ \\
\sum d^{*} \text { Control Variables }+e
\end{gathered}
$$

The above model specifications are similar to models used in prior research (for example, Brown and Caylor, 2006, and Larcker, Richardson, and Tuna, 2007) examining various aspects of corporate governance and firm performance. We examine the relationship between board independence and firm performance after controlling for capital structure and various control variables specific to each firm performance measure.

It is well known that capital structure determination is an important corporate finance decision for a firm. Prior research indicates that aligning the manager's interests too closely with stockholders' interests will result in sub-optimal investment policies and increase the agency cost of debt (John and John, 1993). Thus controlling for capital structure becomes necessary in any examination of firm performance.

We discuss the choice of control variables specific to each firm performance measure in the results section. We also include industry and year indicator variables to control for industry and year fixed effects. For industry controls, we employ the commonly used Fama and French (1997) 48 industry categories.

\section{Empirical Measures of Corporate Performance}

Our study utilizes several metrics of corporate performance. We use Return on

Assets (ROA), defined as earnings before extraordinary items (COMPUSTAT item 18) deflated by beginning total assets, as our measure of operating performance. We also use annual buy-and-hold equity return $(R E T U R N)$, calculated from CRSP for a given year, as the measure of stock performance. Finally, we utilize Tobin's Q, a variable that is often employed to evaluate the impact of governance quality on overall firm value. Prior research has examined the association between Tobin's Q and governance variables such as board size (Yermack, 1996), dual CEO-chair (Yermack, 1996), and board structure (Bhagat and Black, 2002). Consistent with the prior literature, we measure Tobin's Q as total assets plus market value of equity minus book value of equity minus deferred tax, all divided by total assets.

\section{Empirical Measures of Board Independence/Control Variables}

The typical board of directors consists of both inside and outside directors. Inside directors are employees of the firm while independent outside directors have no business or other relationship with the firm that could bias their decision-making. The variable $P C T O N B D$ represents the percentage of independent directors on the board. Klein (2002) finds a negative relation between board committee independence and abnormal accruals. This suggests that boards structured to be more independent of the CEO are more effective monitors of the financial accounting process. Hermalin and Weisbach (2003) find that boards with a greater percentage of outside directors are more likely to dismiss an ineffective manager. Also, Xie et al. (2003) indicate that companies with greater outside representation on the board exhibit a lower level of earnings management. The results of these studies are consistent with the view that independent directors are more effective monitors because they have no ties to management and are, therefore, not biased. However, Bhagat and Black (2002) find no evidence that board independence enhances firm performance. This finding is consistent with the view that independent directors may lack the expertise of company insiders to be effective monitors of management. However, we expect a positive relation between $P C T O N B D$ and our firm performance measures in the post-SOX period. This should result from the tightening of the criteria for a director to be considered "independent."

The director and officer ownership variable (DOHOLDINGS) represents the percentage stockholdings of officers and directors. Officers and directors who own a greater percentage of company stock are more likely to act in the interests of shareholders (McConnell and Servaes, 1990). Klein (2002) finds that the level of earnings management is inversely related to the stockholdings of the CEO. Warfield et al. (1995) hypothesize that the level of managerial ownership affects both the informativeness of earnings and the magnitude of discretionary accounting accrual adjustments. Their results show that managerial ownership is positively associated with earnings' explanatory power for returns and inversely related to the magnitude of accounting accrual adjustments. Therefore, we expect a positive association between DOHOLDINGS and firm performance. However, we also note that higher DOHOLDINGS could reduce the overall board independence.

The variable $R E L$ is an indicator variable which equals " 1 " if the CEO has a relative on the board of directors and " 0 " otherwise. Board members who are related to the CEO are more likely to be biased and, therefore, not as effective at monitoring management. The variable $S E P C H R$ is an indicator variable which equals " 1 " if the CEO is not the chairman of the board 
and " 0 " if the CEO is the chairman of the board. A CEO who is also chairman of the board of directors could undermine the independence of the board by dissuading directors from expressing alternative viewpoints. Companies whose CEO is not also the chairman of the board should have stronger performance.

The variable $L E A D D I R$ is an indicator variable which takes the value of " 1 " if the company has a lead director and " 0 " if not. A lead director is an outside director who is responsible for chairing executive sessions of the board (i.e., meetings of the board with no senior management present). Ideally, these sessions should promote a freer exchange of ideas between directors and thereby enhance corporate performance. However, according to IRRC, "most companies appoint a lead director when the company's chair also serves as CEO, as a way to satisfy shareholders that an independent serves as a conduit of communication to the board." This suggests that boards with a lead director will be less effective monitors of management and, therefore, may have weaker performance.

The number of directors on the board is captured by the indicator variable $B D S I Z E$; this variable equals "1" for boards which are comprised of an optimal board size of four to seven directors, and equals " 0 " otherwise. Dey (2005) defines optimal board size as four to eight members. Yermack (1996) finds that board size and firm performance, as reflected in Tobin's Q, are negatively related. Lipton and Lorsch (1992) suggest that boards with more than seven or eight members are less effective. Therefore, we expect companies with an optimal board size to have stronger performance.

The variable NUMMTGS is an indicator variable which equals " 1 " if a company has between 4 and 12 board meetings per year, and equals " 0 " otherwise. Too many board meetings can be symptomatic of problems at a company. On the other hand, boards that meet infrequently may not be able to monitor the management effectively. Jensen (1993, pg. 866) states that "...in well-functioning organizations the board will be relatively inactive and will exhibit little conflict. It becomes important primarily when the rest of the internal control system is failing, and this should be a relatively rare event." Indeed, Vafeas (1999) finds that the number of board meetings per year is negatively associated with firm value. Therefore, we expect a positive relation between NUMMTGS and firm performance.

The variable COMPMIX is the percentage of total CEO compensation in a given year which is comprised of stock options and restricted stock. This is similar to the variable employed by Larcker et al. (2007); however, we do not include stock compensation in the variable DOHOLDINGS. The link between equity-based compensation and firm performance is not clear. This form of remuneration may induce executives to focus too much on the short-term performance of their stock (Roell, 2008) or even to manipulate information (Goldman and Slezak, 2006). However, Hanlon et al. (2003) find a positive relation between executive compensation which consists of stock options and future earnings. Therefore, we make no directional prediction on the relation between COMPMIX and firm performance.

We use principal components analysis to group the individual board independence variables into composite factors that capture different dimensions of board independence. This results in the identification of four composite factors that retain 63 percent of the variance in the individual corporate governance variables. We use varimax oblique rotation to minimize the number of variables that have high loadings on each factor so that we can more easily interpret the factors.

The individual board independence variables associated with factor one $(F B I)$ are $P C T O N B D$, DOHOLDINGS and REL. We label this factor the board independence factor. Factor two $(F B L)$, labeled the board leadership factor, is highly associated with SEPCHR and LEADDIR. The variable BDSIZE is the only factor with a high loading on factor three $(F B S)$, the board size factor. The variables NUMMTGS and COMPMIX are highly associated with factor four $(F O T H)$, the "other" board factor. The board size factor $(F B S)$ and the "other" board factor $(F O T H)$ are essentially control variables in our analysis.

\section{Empirical Analysis}

\subsection{Descriptive Statistics}

Table 1 reports descriptive statistics for the corporate performance measures, the board independence variables, and the control variables. The mean (median) return on assets and buy-and-hold stock return for our sample firms are 4.0 percent (3.9 percent) and 15.5 percent (12.5 percent), respectively. Independent directors comprise approximately 71 percent of the board for our sample firms; this is consistent with Gordon (2006). On average, 21.4 percent of our sample firms have the optimal board size of four to seven members; and 92.9 percent of our sample firms have the optimal number of board meetings of four to twelve per fiscal year. The CEO is not the chairman of the board for 35 percent of our sample firms; this is somewhat higher than the 23 percent reported by Larcker et al. (2007) using 20022003 data, indicative of more recent governance improvements. Also, 41 percent of the firms have a lead director; this is significantly higher than the 8 percent reported by Larcker, Richardson, and Tuna (2007). Stock options and restricted stock comprise approximately 43 percent of the typical CEO compensation package. Directors and officers own an average of 10 percent of their company's stock. 


\subsection{Relation between ROA and Board Independence}

Table 2 reports the OLS estimation results using ROA as the firm performance measure for the post-SOX period. We employ three variants of $R O A$ as the dependent variable in our regressions $-R O A$ for the current year, ROA for the next year and the $R O A$ average for the next two years. The control variables for the ROA regressions include total firm assets (LnASSET), the past/current year return on assets (LROA/ROA), and leverage (LEV). Firm operating performance should tend to persist over time; the coefficient on ROA should therefore be positive. Highly levered firms should exhibit strong (weak) operating performance during good (poor) economic times; therefore, $L E V$ (i.e., the firm debt ratio) could be positively or negatively associated with future ROA.

Panel A of Table 2 presents results using the individual governance variables as regressors. The variables PCTONBD, SEPCHR and DOHOLDINGS each exhibit a statistically significant positive relation, as predicted, with both next year's ROA and the average ROA for the next two years. Boards with a greater percentage of independent directors and a chair who is not also the CEO should not be biased toward management; therefore, they are more effective monitors of management. Boards whose members own a greater percentage of company stock are more likely to look out for the interests of shareholders (McConnell and Servaes, 1990) and thereby enhance firm performance. Also, REL has a significant negative relationship with next year's ROA.

The additional variables, BDSIZE and NUMMTGS, also are significantly positively related to both next year's ROA and the average ROA for the next two years. Firms with an optimal board size have better operating performance; this is consistent with Yermack (1996). Companies whose boards have an optimal number of meetings each fiscal year also have stronger operating performance; this is consistent with Vafeas (1999). Interestingly, COMPMIX has a statistically significant positive relationship with the average ROA for the next two years. Greater stockbased compensation for the CEO enhances firm performance; this is consistent with the Hanlon, Rajgopal, and Shevlin (2003) finding.

Panel B of Table 2 provides results when using the four governance factors as regressors. As expected, the board leadership factor $(F B L)$ has a significant positive relationship with the next two year's average ROA. Firms with stronger board leadership (i.e., those with a CEO who is not chairman of the board and that have no lead director) also have stronger operating performance. There is a significant positive relationship between the board size factor $(F B S)$ and both next year's ROA and the average ROA for the next two years; firms which have an optimal board size are more effective monitors of management and thereby have stronger operating performance. The "other" board factor $(F O T H)$ also exhibits a significant, positive relation with both future ROA metrics. Firms with an optimal board meeting frequency and stock-based CEO compensation have stronger operating performance. The control variable $R O A$ is significantly positively related to future $R O A$ while $L E V$ is negatively related to future ROA. As a robustness check, we also correct for firm level clustering of standard errors. Untabulated results indicate that the significance levels are similar to the results reported for the ROA regressions with controls for fixed industry and years effects.

\subsection{Relation between Equity Returns and Board Independence}

Firm equity returns are the dependent variables for the OLS estimation results for the post-SOX period presented in Table 3. We again employ three variants of the dependent variable - current year equity returns, next year equity returns, and the equity return average for the next two years. The control variables for the equity return regressions include $L E V$, the ratio of market value of equity to book value of equity $(M B)$, firm size ( $L n M V E)$, and stock return volatility over the year (VOLAT). Firm leverage could be positively or negatively related to equity returns depending on the state of the economy. Firms with a lower market-to-book ratio of equity (i.e., value stocks) and smaller companies may have higher future equity returns (Fama and French, 1992). Firms with higher stock return volatility over the previous year may have higher equity returns given their higher risk level. However, we do not develop predictions for the control variables.

Panel A of Table 3 presents results using the individual governance variables as regressors. As expected, PCTONBD has a significant, positive relation with both next year's equity return and the average of the next two years' equity returns; this is consistent with Larcker, Richardson, and Tuna. (2007). Boards with a greater percentage of independent directors are more effective monitors of management and thereby contribute to higher equity returns. NUMMTGS and SEPCHR each exhibit, as predicted, significant positive relationships with both current equity returns and the average of the next two year's equity returns. Boards which have an optimal number of meetings and whose CEO is not the chair enhance equity returns.

Panel B of Table 3 presents the results for regressions employing the four governance factors as regressors. The results indicate that, as predicted, the board independence factor $(F B I)$ is significantly positively related to next year's equity returns and the average of the next two years' equity returns. Also, the board leadership factor $(F B L)$ has a significant 
positive relationship with the equity return average for the next two years, and the "other" board factor $(F O T H)$ is significantly positively related to current year equity returns. Firms with more independent boards, stronger board leadership, and stock-based compensation for the CEO have higher equity returns. The market-to-book and size control variables have significant negative relationships with future equity returns while the volatility control variable has a significant positive relationship with future equity returns.

\subsection{Relation between Tobin's $Q$ and Board Independence}

Our third firm performance measure, Tobin's Q, is the dependent variable for the OLS estimation results presented in Table 4. We employ three variants of the dependent variable - the current year's Tobin's Q, next year's Tobin's Q, and two years' ahead Tobin's Q. The control variables for these regressions include firm total assets (LnASSET) and LEV. Since Tobin's $\mathrm{Q}$ has total assets as the denominator, we include LnASSET as a control variable. Firm leverage could be positively or negatively related to Tobin's Q depending on the state of the economy.

Panel A presents regression results employing the individual governance variables as regressors. The variables SEPCHR, DOHOLDINGS, BDSIZE and $C O M P M I X$ are each significantly positively related to the three Tobin's Q variants. Firms which have an optimal board size, a CEO who is not the chairman of the board, equity-based compensation, and a high level of board stock ownership exhibit stronger performance. In addition, REL has, as predicted, a significant negative relationship with each Tobin's $Q$ measure.

Regression results using the four governance factors as regressors are provided in Panel B of Table 4. The board leadership factor $(F B L)$, the board size factor $(F B S)$, and the "other" board factor $(F O T H)$ each exhibit, as hypothesized, statistically significant positive relationships with the three Tobin's Q measures. Boards that have no lead director, a chairman who is not the CEO, an optimal board size, an optimal number of meetings, and equity-based compensation for the CEO exhibit higher Tobin's Q. Both of the control variables, $L E V$ and SIZE, are significantly negatively related to Tobin's Q.

\subsection{Additional Analysis}

We summarize the results of several additional tests in this section. First, we employ a pooled regression approach to relate our individual governance variables to the performance measures in both the pre-SOX period (i.e., 1998-2001) and the post-SOX period. This enables us to examine whether SOX has strengthened the link between board independence and firm performance. Our pooled regression results demonstrate not only that the relationship between the percentage of independent directors on the board and firm performance (i.e., Tobin's Q) is significantly negative in the pre-SOX period, but also that this relationship is significantly more positive (using all three firm performance metrics) in the post-SOX period. This is compelling evidence that SOX has strengthened the positive link between board independence and firm performance.

Second, we test whether there might be an endogenous relationship between the board structure and firm performance. We use the approach followed by Larcker et al. (2007) as a way to provide some insight into the impact of endogeneity on our main results. Similar to Larcker et al. (2007), we assume that two of the primary variables that determine governance structure are firm size (measured as the natural logarithm of the market value of equity) and industrial classification (measured by Fama and French (1997) industry factors). Each governance variable is regressed on firm size and industry and the OLS residuals for each of the eight governance constructs are retained. Then, we repeat our tests of future firm performance reported in Panel A of Tables 2-4 using residuals for each of the eight governance constructs as explanatory variables. The untabulated results are qualitatively similar to those reported in Tables 2-4, thus alleviating the concern that the results in Tables 2-4 are driven by endogeneity.

Third, we examine whether our results are driven by family (owner-manager) firms. We do so by re-estimating the models after deleting observations with DOHOLDINGS greater than $50 \%$ (i.e., ownermanager firms) and DOHOLDINGS greater than $25 \%$ (high managerial ownership firms). Our inferences are not altered, indicating that our findings are unlikely to be driven by owner-manager firms or high managerial ownership firms.

Finally, we examine whether our results hold after controlling for capital expenditures, an alternate proxy for future growth. We re-estimate the models in Panel B of Tables 2-4 after including net capital expenditures (capital expenditures less depreciation) as an additional regressor. The untabulated results are consistent with the results in Panel B of Tables 2-4, indicating that those results are robust to controlling for future growth prospects.

\section{Conclusions}

We examine the relationship between firm performance and board independence in the post-SOX period of 2002-2005. Our study has several advantages over previous research in this area. First, we consider several firm performance metrics - return on assets, buy-and-hold equity returns, and Tobin's Q. Second, we utilize principal components analysis to group our board independence variables into two factors. By doing so, we are able to capture the extent 
to which boards are truly independent and reflect strong leadership.

We argue that the adoption of SOX has resulted in independent outside directors being more effective monitors of management for several reasons. Independent outside directors are now being held more accountable. For example, such directors at both Enron and WorldCom were found liable for their actions in multi-million dollar lawsuits. This increased liability should compel such directors to perform their duties more effectively. In addition, outside directors must now meet the more stringent requirements of both the NYSE and NASDAQ to be considered "independent". Such directors will not be independent in name only. Also, directors now hold fewer directorships and the fraction of directors who are retired has increased (Chhaochharia and Grinstein, 2007); this implies that directors now have more time to perform their duties and should, therefore, be more effective monitors of management (Fich and Shivdasani, 2006).

While previous research yields inconclusive results, our study clearly demonstrates that firms with more independent boards have stronger performance in the post-SOX period. Boards which have more independent directors have fewer potential conflicts of interest with management; such boards, therefore, are more effective monitors of management leading to stronger company financial performance.

\section{References}

1. Agrawal, A. and Knoeber, C. (1996), "Firm performance and mechanisms to control agency problems between managers and shareholders," Journal of Financial and Quantitative Analysis, Vol. 31 No. 3, pp. 377-397.

2. Baysinger B. and Butler H. (1985), "Corporate governance and the board of directors: performance effects of changes in board composition," Journal of Law, Economics, and Organization, Vol. 1, pp. 101124.

3. Bhagat, S. and Black, B. (2002), "The non-correlation between board independence and long-term firm performance," Journal of Corporation Law, Vol. 27 No. 2, pp. 231-273.

4. Brown, L. and Caylor, M. (2006), "Corporate governance and firm valuation," Journal of Accounting and Public Policy, Vol. 25, pp. 409-434.

5. Byrd, J. and Hickman, K. (1992), "Do outside directors monitor managers?" Journal of Financial Economics, Vol. 32, pp.195-221.

6. Chhaochharia, V. and Grinstein, Y. (2007), "Corporate governance and firm value: the impact of the 2002 governance rules," Journal of Finance, Vol. 62, pp. 1789-1825.

7. Dey, A. (2005), "Corporate governance and financial reporting credibility," Working paper, University of Chicago.
8. Fama, E. and Jensen, M. (1983), "Separation of ownership and control," Journal of Law and Economics, Vol. 26, pp. 301-326.

9. Fama, E. and French, K. (1992), "The cross-section of expected stock returns," Journal of Finance, Vol. 47, No. 2, pp. 427-465.

10. Fama, E. and French, K. (1997), "Industry costs of equity," Journal of Financial Economics, Vol. 43, pp. 153-194.

11. Fich, E. and Shivdasani, A. (2006), "Are busy boards effective monitors?" Journal of Finance, Vol. 61, No. 2, pp. 689-724.

12. Goldman, E. and Slezak, S. (2006), “An equilibrium model of incentive contracts in the presence of information manipulation," Journal of Financial Economics, Vol. 80, No. 3, pp. 603-626.

13. Gordon, J. (2007), "The rise of independent directors in the United States, 1950-2005: Of shareholder value and stock market prices," Columbia Law and Economics Working Paper No. 323.

14. Hanlon, M., Rajgopal, S. and Shevlin, T. (2003), "Are executive stock options associated with future earnings?", Journal of Accounting and Economics, Vol. 36 No. 1-3, pp.3-44.

15. Hermalin, B. and Weisbach, M. (2003), "Boards of directors as an endogenously determined institution: A survey of the economic literature," FRBNY Economic Policy Review, Vol. 9 No.1, pp. 7-26.

16. Jensen, M., (1993), "The modern industrial revolution, exit, and the failure of internal control systems," The Journal of Finance, Vol. 48, pp. 831-880.

17. John, T. and John, K. (1993), "Top management compensation and capital structure," The Journal of Finance, Vol. 48 No. 3, pp. 949-974.

18. Klausner, M., Black, B. and Cheffins, B. (2005), "Outside directors' liability: Have WorldCom and Enron changed the rules?" Stanford Lawyer, pp. 36-39.

19. Klein, A. (2002), "Audit committee, board of director characteristics, and earnings management," Journal of Accounting and Economics, Vol. 33 No. 3, pp. 375400.

20. Larcker, D., Richardson, S., and Tuna, I. (2007), "Corporate governance, accounting outcomes, and organizational performance," The Accounting Review, Vol. 82 No. 4, pp. 963-1008.

21. Le S., Walters B., Kroll M. (2006), "The moderating effects of external monitors on the relationship between R\&D spending and firm performance," Journal of Business Research, Vol. 59, pp. 278-287.

22. Lefort, F., Urzua, F. (2008), "Board independence, firm performance and ownership concentration: evidence from Chile," Journal of Business Research, Vol. 61, pp. 615-622.

23. Lipton, M. and Lorsch, J. (1992), “A modest proposal for improved corporate governance," Business Lawyer, Vol. 48 No. 1, pp. 59-77. 
24. McConnell, J. and Servaes, H. (1990), "Additional evidence on equity ownership and corporate value," Journal of Financial Economics, Vol. 27, pp. 595-612.

25. Milgram S. (1974), Obedience to Authority, Harper and Row, New York, N.Y.

26. Molz R. (1988), "Managerial domination of boards of directors and financial performance," Journal of Business Research, Vol. 16, pp.235-249.

27. Morck R. (2004), "Behavioral finance in corporate governance - independent directors and non-executive chairs," Harvard Institute of Economic Research Discussion Paper Number 2037.

28. Roell, A. (2008), "Executive pay and shareholder litigation," Review of Finance, Vol. 12, No. 1, pp. 141184.

29. Rosenstein, S. and Wyatt, J. (1990), "Outside directors, board independence, and shareholder wealth," Journal of Financial Economics, Vol. 26, pp. 175-192.

30. Vafeas, N. (1999), "Board meeting frequency and firm performance," Journal of Financial Economics, Vol. 53, pp. 113-142.
31. Vance S. (1978), "Corporate governance: assessing corporate performance by boardroom attributes," Journal of Business Research, Vol. 6, pp.203-220.

32. Walters, B., Kroll M., Wright, P. (2007), "CEO tenure, boards of directors, and acquisition performance," Journal of Business Research, Vol. 60, pp. 331-338.

33. Warfield, T., Wild J., and Wild K. (1995), "Managerial ownership, accounting choices, and informativeness of earnings," Journal of Accounting and Economics, Vol. 20 No.1, pp. 61-91

34. Weisbach, M. (1988), "Outside directors and CEO turnover," Journal of Financial Economics, Vol. 20, pp. 431-460.

35. Xie, B., Davidson, W., DaDalt, P. (2003), "Earnings management and corporate governance: The role of the board and the audit committee," Journal of Corporate Finance, Vol. 9, No. 3, pp. 295-316.

36. Yermack, D. (1996), "Higher market valuation of companies with a small board of directors," Journal of Financial Economics, Vol. 40, pp. 185-211. 
Table 1. Descriptive Statistics

\begin{tabular}{|l|c|c|c|c|c|c|}
\hline Variable & $\mathrm{N}$ & Mean & Std Dev & $25 \%$ & Median & $75 \%$ \\
\hline ROA & 3008 & 0.0397 & 0.0820 & 0.0137 & 0.0385 & 0.0738 \\
\hline RETURN & 2854 & 0.1550 & 0.4075 & -0.0656 & 0.1246 & 0.3269 \\
\hline TOBIN'S $Q$ & 3008 & 1.8209 & 1.0809 & 1.1563 & 1.4762 & 2.0412 \\
\hline BDSIZE & 3008 & 0.2144 & 0.4105 & 0.0000 & 0.0000 & 0.0000 \\
\hline NUMMTGS & 3008 & 0.9292 & 0.2566 & 1.0000 & 1.0000 & 1.0000 \\
\hline PCTONBD & 3008 & 71.0167 & 14.0920 & 61.5000 & 72.7135 & 81.8180 \\
\hline REL & 3008 & 0.1393 & 0.3463 & 0.0000 & 0.0000 & 0.0000 \\
\hline SEPCHR & 3008 & 0.3531 & 0.4780 & 0.0000 & 1.0000 & 1.0000 \\
\hline LEADDIR & 3008 & 0.4146 & 0.4927 & 0.0000 & 0.0000 & 1.0000 \\
\hline COMPMIX & 3008 & 0.4272 & 0.2795 & 0.2005 & 0.4580 & 0.6460 \\
\hline DOHOLDINGS & 3008 & 10.0803 & 13.6687 & 2.6000 & 5.2800 & 11.2000 \\
\hline FBI & 3008 & 41.0673 & 16.5780 & 33.0246 & 44.9050 & 53.1364 \\
\hline FBL & 3008 & -0.0066 & 0.5467 & -0.6820 & 0.0000 & 0.4410 \\
\hline FBS & 3008 & 0.2144 & 0.4105 & 0.0000 & 0.0000 & 0.0000 \\
\hline FOTH & 3008 & 1.0167 & 0.2598 & 0.9336 & 1.0802 & 1.1688 \\
\hline LEV & 3008 & 0.1873 & 0.1567 & 0.0430 & 0.1677 & 0.2933 \\
\hline LnASSET & 3008 & 7.6964 & 1.3941 & 6.0727 & 6.7167 & 7.5746 \\
\hline LnMVE & 2854 & 7.8976 & 1.6837 & 6.6328 & 7.7578 & 8.9959 \\
\hline VOLAT & 2854 & 0.0925 & 0.0534 & 0.0570 & 0.0790 & 0.1120 \\
\hline
\end{tabular}

1. Variable Definitions:

$R O A=\quad$ return on assets;

RETURN = annual buy-and-hold equity return;

TOBIN'S $Q=$ Tobin's Q computed as (total assets + market value of equity- book value of equity -

deferred tax) all divided by total assets ;

$B D S I Z E=\quad$ indicator variable which equals ' 1 ' for boards which are comprised of an optimal board size of four to seven members and ' 0 ' otherwise ;

NUMMTGS = indicator variable which equals ' 1 ' if a company has between four and twelve board meetings per year and ' 0 ' otherwise ;

$P C T O N B D=$ percentage of independent directors on the board;

$R E L=$ indicator variable for relatives on board ; equals " 1 " if the CEO has a relative on the board of directors and " 0 " otherwise;

$S E P C H R=$ indicator variable which equals " 1 " if the CEO is not the chairman of the board and " 0 " otherwise;

$L E A D D I R=\quad$ indicator variable which equals " 1 " if the company has a lead director and " 0 " otherwise;

$C O M P M I X=\quad$ Compensation mix;

DOHOLDINGS= percentage stock holdings of directors and officers;

$F B I=$

$F B L=$ board independence factor $\left(0.686^{*} P C T O N B D-0.749 * D O H O L D I N G S-0.718^{*} R E L\right)$;

$F B S=$ board leadership factor $(0.782 * S E P C H R-0.682 * L E A D D I R)$;

other board factor $(0.896 * N U M M T G S+0.431 * C O M P M I X)$;

$L E V=\quad$ firm debt ratio (i.e., total debt/total assets);

LnASSET $=\quad$ natural log of firm's total assets;

LnMVE $=\quad$ natural log of firm's market value of equity; and

VOLAT $=\quad$ stock return volatility based on standard deviation of 12 months stock returns for the current year. 
Table 2. Relationship between Future Operating Performance and Governance Variables and Governance Factors

\section{Panel A: Individual Governance Variables}

\begin{tabular}{|c|c|c|c|c|c|c|c|}
\hline \multirow[t]{2}{*}{ Variable } & \multirow{2}{*}{$\begin{array}{l}\text { Predicted } \\
\text { Sign }\end{array}$} & \multicolumn{2}{|c|}{ Current ROA } & \multicolumn{2}{|c|}{ Next year ROA } & \multicolumn{2}{|c|}{ Next two years ROA } \\
\hline & & Coeff. & $t$-stats & Coeff. & $t$-stats & Coeff. & $t$-stats \\
\hline Intercept & $?$ & 0.0453 & $3.83 * * *$ & -0.0058 & -0.53 & -0.0125 & -1.07 \\
\hline PCTONBD & + & 0.0001 & 0.87 & 0.0001 & $1.43 *$ & 0.0001 & $1.30 *$ \\
\hline$R E L$ & - & -0.0022 & -0.57 & -0.0061 & $-1.76 * *$ & -0.0036 & -0.97 \\
\hline DOHOLDINGS & + & 0.0001 & 0.64 & 0.0002 & $2.02 * *$ & 0.0002 & $2.33 * * *$ \\
\hline SEPCHR & + & -0.0012 & -0.45 & 0.0031 & $1.30 *$ & 0.0064 & $2.47 * * *$ \\
\hline LEADDIR & - & -0.0009 & -0.36 & 0.0004 & 0.19 & -0.0019 & -0.74 \\
\hline$B D S I Z E$ & + & -0.0031 & -0.98 & 0.0056 & $1.92 * *$ & 0.0074 & $2.37 * * *$ \\
\hline NUMMTGS & + & -0.0021 & -0.45 & 0.0127 & $3.03 * * *$ & 0.013 & $3.02 * * *$ \\
\hline COMPMIX & $?$ & 0.0007 & 0.15 & 0.0042 & 1.04 & 0.0105 & $2.45 * *$ \\
\hline LnASSET & - & -0.0014 & $-1.56^{*}$ & 0.0000 & 0.00 & 0.0007 & 0.86 \\
\hline$L E V$ & $?$ & -0.0511 & $-6.11 * * *$ & -0.0196 & $-2.54 * *$ & -0.0197 & $-2.35 * *$ \\
\hline$L R O A$ & + & 0.5046 & $40.17 * * *$ & & & & \\
\hline$R O A$ & + & & & 0.6125 & $45.20 * * *$ & 0.5179 & $36.42 * * *$ \\
\hline Year controls & & \multicolumn{2}{|c|}{ Yes } & \multicolumn{2}{|c|}{ Yes } & \multicolumn{2}{|c|}{ Yes } \\
\hline $\begin{array}{l}\text { Industry } \\
\text { controls }\end{array}$ & & \multicolumn{2}{|c|}{ Yes } & \multicolumn{2}{|c|}{ Yes } & \multicolumn{2}{|c|}{ Yes } \\
\hline Observations & & \multicolumn{2}{|c|}{3008} & \multicolumn{2}{|c|}{3008} & \multicolumn{2}{|c|}{2182} \\
\hline F-Value & & \multicolumn{2}{|c|}{44.61} & \multicolumn{2}{|c|}{53.17} & \multicolumn{2}{|c|}{35.73} \\
\hline Adjusted $\mathrm{R}^{2}$ & & \multicolumn{2}{|c|}{$41.04 \%$} & \multicolumn{2}{|c|}{45.44} & \multicolumn{2}{|c|}{$43.32 \%$} \\
\hline
\end{tabular}

1. Variable Definitions:

LnASSET $=\quad$ natural log of firm's total assets;

$L R O A=\quad$ return on assets for the past year;

$R O A=\quad$ return on assets;

$L E V=\quad$ firm debt ratio (i.e., total debt/total assets); and

.All other variables are defined in Table 1.

2. *** significant at 0.01 level, ** significant at 0.05 level, * significant at 0.10 level. Significance levels are based on one-tailed tests when the coefficient sign is predicted and on two-tailed tests otherwise. 


\section{Panel B: Governance Factors}

\begin{tabular}{|c|c|c|c|c|c|c|c|}
\hline \multirow[t]{2}{*}{ Variable } & \multirow{2}{*}{$\begin{array}{l}\text { Predicted } \\
\text { Sign }\end{array}$} & \multicolumn{2}{|c|}{ Current ROA } & \multicolumn{2}{|c|}{ Next year ROA } & \multicolumn{2}{|c|}{ Next two years ROA } \\
\hline & & Coeff. & $t$-stats & Coeff. & $t$-stats & Coeff. & $t$-stats \\
\hline Intercept & $?$ & 0.0490 & $5.38 * * *$ & 0.0076 & 0.91 & 0.0012 & 0.14 \\
\hline$F B I$ & + & 0.00004 & 0.45 & 0.00001 & 0.11 & -0.00003 & -0.46 \\
\hline$F B L$ & + & -0.0004 & -0.19 & 0.0015 & 0.73 & 0.0055 & $2.46 * * *$ \\
\hline$F B S$ & + & -0.0028 & -0.87 & 0.0059 & $2.03 * *$ & 0.0077 & $2.48 * * *$ \\
\hline FOTH & + & -0.0014 & -0.32 & 0.0133 & $3.20 * * *$ & 0.0172 & $3.84 * * *$ \\
\hline LnASSET & - & -0.0014 & $-1.63 *$ & -0.02 & $-2.61 * * *$ & 0.0006 & 0.76 \\
\hline$L E V$ & $?$ & -0.0518 & $-6.24 * * *$ & -0.0003 & -0.36 & -0.0203 & $-2.44 * *$ \\
\hline$L R O A$ & + & 0.5051 & $40.29 * * *$ & & & & \\
\hline$R O A$ & + & & & $0.6129 * * *$ & 45.25 & $0.5174 * * *$ & 36.43 \\
\hline $\begin{array}{l}\text { Year } \\
\text { controls }\end{array}$ & & \multicolumn{2}{|c|}{ Yes } & \multicolumn{2}{|c|}{ Yes } & \multicolumn{2}{|c|}{ Yes } \\
\hline $\begin{array}{l}\text { Industry } \\
\text { controls }\end{array}$ & & \multicolumn{2}{|c|}{ Yes } & \multicolumn{2}{|c|}{ Yes } & \multicolumn{2}{|c|}{ Yes } \\
\hline Observations & & \multicolumn{2}{|c|}{3008} & \multicolumn{2}{|c|}{3008} & \multicolumn{2}{|c|}{2182} \\
\hline F-Value & & \multicolumn{2}{|c|}{48.67} & \multicolumn{2}{|c|}{57.72} & \multicolumn{2}{|c|}{38.76} \\
\hline Adjusted $\mathrm{R}^{2}$ & & \multicolumn{2}{|c|}{$41.09 \%$} & \multicolumn{2}{|c|}{45.36} & \multicolumn{2}{|c|}{$43.24 \%$} \\
\hline
\end{tabular}

1. Variable Definitions:

$F B I=\quad$ board independence factor $\left(0.686^{*} P C T O N B D-0.749 * D O H O L D I N G S-0.718^{*} R E L\right)$;

$F B L=\quad$ board leadership factor $(0.782 * S E P C H R-0.682 * L E A D D I R)$;

$F B S=\quad$ board size factor $(0.901 * B D S I Z E)$;

$F O T H=\quad$ other board factor $(0.896 * N U M M T G S+0.431 * C O M P M I X)$;

LnASSET $=\quad$ natural log of firm's total assets;

$L R O A=\quad$ return on assets for the past year;

$R O A=\quad$ return on assets; and

$L E V=\quad$ firm debt ratio (i.e., total debt/total assets); and

All other variables are defined in Table 1.

2. *** significant at 0.01 level, ** significant at 0.05 level, * significant at 0.10 level. Significance levels are based on one-tailed tests when the coefficient sign is predicted and on two-tailed tests otherwise. 
Table 3. Relationship between Future Equity Returns and Governance Variables and Governance Factors

Panel A: Individual Governance Variables

\begin{tabular}{|c|c|c|c|c|c|c|c|}
\hline \multirow[t]{2}{*}{ Variable } & \multirow{2}{*}{$\begin{array}{l}\text { Predicted } \\
\text { Sign }\end{array}$} & \multicolumn{2}{|c|}{ Current Return } & \multicolumn{2}{|c|}{ Next year Return } & \multicolumn{2}{|c|}{ Next two years Return } \\
\hline & & Coeff. & $t$-stats & Coeff. & $t$-stats & Coeff. & $t$-stats \\
\hline Intercept & $?$ & 0.3239 & $5.39 * * *$ & 0.0966 & 1.62 & 0.1420 & 1.19 \\
\hline PCTONBD & + & -0.0003 & -0.73 & 0.0009 & $2.12 * *$ & 0.0019 & $2.20 * *$ \\
\hline$R E L$ & - & -0.0208 & -1.17 & 0.0105 & 0.60 & 0.0190 & 0.55 \\
\hline DOHOLDINGS & + & -0.0003 & -0.53 & -0.0004 & -0.7 & -0.0010 & -1.03 \\
\hline SEPCHR & + & 0.0161 & $1.31 *$ & 0.0140 & 1.17 & 0.0435 & $1.81 * *$ \\
\hline LEADDIR & - & 0.0041 & 0.34 & 0.0018 & 0.15 & -0.0042 & -0.17 \\
\hline$B D S I Z E$ & + & -0.0135 & -0.89 & 0.0086 & 0.58 & 0.0369 & $1.30 *$ \\
\hline NUMMTGS & + & 0.0573 & $2.64 * * *$ & 0.0179 & 0.85 & 0.0756 & $1.76^{* *}$ \\
\hline СОМРМIX & $?$ & -0.0366 & $-1.70^{*}$ & -0.0123 & -0.59 & -0.0375 & -0.91 \\
\hline$L E V$ & $?$ & -0.0486 & -1.24 & 0.0650 & $1.71 *$ & 0.1868 & $2.43 * *$ \\
\hline$L M B$ & $?$ & 0.0004 & 0.22 & & & & \\
\hline$M B$ & $?$ & & & -0.0089 & $-3.31 * * *$ & -0.0137 & $-2.54 * *$ \\
\hline LLnMVE & $?$ & -0.024 & $-4.91 * * *$ & & & & \\
\hline LnMVE & $?$ & & & -0.0084 & $-1.73 *$ & -0.0206 & $-2.12 * *$ \\
\hline LVOLAT & $?$ & -0.0567 & -0.48 & & & & \\
\hline VOLAT & $?$ & & & 0.7230 & $5.29 * * *$ & 0.9427 & $3.67 * * *$ \\
\hline $\begin{array}{l}\text { Industry } \\
\text { controls }\end{array}$ & & \multicolumn{2}{|c|}{ Yes } & \multicolumn{2}{|c|}{ Yes } & \multicolumn{2}{|c|}{ Yes } \\
\hline Observations & & \multicolumn{2}{|c|}{2854} & \multicolumn{2}{|c|}{2854} & \multicolumn{2}{|c|}{2096} \\
\hline F-Value & & \multicolumn{2}{|c|}{23.53} & \multicolumn{2}{|c|}{12.18} & \multicolumn{2}{|c|}{12.60} \\
\hline Adjusted $\mathrm{R}^{2}$ & & \multicolumn{2}{|c|}{$28.30 \%$} & \multicolumn{2}{|c|}{$16.43 \%$} & \multicolumn{2}{|c|}{$21.34 \%$} \\
\hline
\end{tabular}

1. Variable Definitions:

$L E V=\quad$ firm debt ratio (i.e., total debt/total assets);

$L M B=$ market value of equity to book value of equity at the beginning of the year;

$L L n M V E=\quad$ natural log of firm's market value of equity at the beginning of the year;

LVOLAT $=\quad$ stock return volatility based on standard deviation of past 12 months stock returns;

$M B=$ market value of equity to book value of equity;

LnMVE $=\quad$ natural log of firm's market value of equity; and

VOLAT $=\quad$ stock return volatility based on standard deviation of current 12 months stock returns); and all other variables are defined in Table 1.

2. *** significant at 0.01 level, ** significant at 0.05 level, * significant at 0.10 level. Significance levels are based on one-tailed tests when the coefficient sign is predicted and on two-tailed tests otherwise. 


\section{Panel B: Governance Factors}

\begin{tabular}{|c|c|c|c|c|c|c|c|}
\hline \multirow[t]{2}{*}{ Variable } & \multirow{2}{*}{$\begin{array}{l}\text { Predicted } \\
\text { Sign }\end{array}$} & \multicolumn{2}{|c|}{ Current Return } & \multicolumn{2}{|c|}{ Next year Return } & \multicolumn{2}{|c|}{ Next two years Return } \\
\hline & & Coeff. & $t$-stats & Coeff. & $t$-stats & Coeff. & $t$-stats \\
\hline Intercept & $?$ & 0.3330 & $7.06 * * *$ & 0.149 & $3.163 * * *$ & 0.2631 & $2.81 * * *$ \\
\hline$F B I$ & + & -0.00003 & -0.09 & 0.0008 & $2.12 * *$ & 0.0018 & $2.43 * * *$ \\
\hline$F B L$ & + & 0.0084 & 0.79 & 0.0088 & 0.86 & 0.0336 & $1.63^{*}$ \\
\hline$F B S$ & + & -0.0151 & -1.01 & 0.0064 & 0.44 & 0.0307 & 1.06 \\
\hline FOTH & + & 0.0347 & $1.60 *$ & 0.0104 & 0.50 & 0.0481 & 1.14 \\
\hline$L E V$ & $?$ & -0.0482 & -1.24 & 0.0615 & 1.63 & 0.1789 & $2.35 * *$ \\
\hline$L M B$ & $?$ & 0.0004 & 0.27 & & & & \\
\hline$M B$ & $?$ & & & -0.0088 & $-3.30 * * *$ & -0.0136 & $-2.53 * *$ \\
\hline LLnMVE & $?$ & -0.0268 & $-5.67 * * *$ & & & & \\
\hline LnMVE & $?$ & & & -0.0097 & $-2.07 * *$ & -0.0251 & $-2.68 * * *$ \\
\hline LVOLAT & $?$ & -0.0718 & -0.61 & & & & \\
\hline VOLAT & $?$ & & & 0.7062 & $5.20 * * *$ & 0.8886 & $3.49 * * *$ \\
\hline $\begin{array}{l}\text { Industry } \\
\text { controls }\end{array}$ & & \multicolumn{2}{|c|}{ Yes } & \multicolumn{2}{|c|}{ Yes } & \multicolumn{2}{|c|}{ Yes } \\
\hline Observations & & \multicolumn{2}{|c|}{2854} & \multicolumn{2}{|c|}{2854} & \multicolumn{2}{|c|}{2096} \\
\hline F-Value & & \multicolumn{2}{|c|}{25.32} & \multicolumn{2}{|c|}{13.19} & \multicolumn{2}{|c|}{13.62} \\
\hline Adjusted $\mathrm{R}^{2}$ & & \multicolumn{2}{|c|}{$28.17 \%$} & \multicolumn{2}{|c|}{$16.47 \%$} & \multicolumn{2}{|c|}{$21.32 \%$} \\
\hline
\end{tabular}

1. Variable Definitions:

$F B I=\quad$ board independence factor $\left(0.686^{*} P C T O N B D-0.749 * D O H O L D I N G S-0.718^{*} R E L\right)$;

$F B L=\quad$ board leadership factor $(0.782 * S E P C H R-0.682 * L E A D D I R)$;

$F B S=\quad$ board size factor $(0.901 * B D S I Z E)$;

$F O T H=\quad$ other board factor $(0.896 * N U M M T G S+0.431 * C O M P M I X)$;

$L E V=\quad$ firm debt ratio (i.e., total debt/total assets);

$L M B=$ market value of equity to book value of equity at the beginning of the year;

$L L n M V E=\quad$ natural log of firm's market value of equity at the beginning of the year;

LVOLAT $=\quad$ stock return volatility based on standard deviation of past 12 months stock returns;

$M B=$ market value of equity to book value of equity;

$L n M V E=\quad$ natural log of firm's market value of equity; and

VOLAT $=\quad$ stock return volatility based on standard deviation of current 12 months stock returns and all other variables are defined in Table 1.

2. *** significant at 0.01 level, ** significant at 0.05 level, * significant at 0.10 level. Significance levels are based on one-tailed tests when the coefficient sign is predicted and on two-tailed tests otherwise. 
Table 4. Relationship between Future Tobin's Q and Governance Variables and Governance Factors

Panel A: Individual Governance Variables

\begin{tabular}{|c|c|c|c|c|c|c|c|}
\hline \multirow[t]{2}{*}{ Variable } & \multirow{2}{*}{$\begin{array}{l}\text { Predicted } \\
\text { Sign }\end{array}$} & \multicolumn{2}{|c|}{ Current Tobin's $Q$} & \multicolumn{2}{|c|}{ Next year Tobin's $Q$} & \multicolumn{2}{|c|}{$\begin{array}{c}\text { Two years ahead } \\
\text { Tobin's } Q\end{array}$} \\
\hline & & Coeff. & $t$-stats & Coeff. & $t$-stats & Coeff. & $t$-stats \\
\hline Intercept & $?$ & 2.5887 & $13.96 * * *$ & 2.3936 & $14.86 * * *$ & 2.3550 & $12.10 * * *$ \\
\hline PCTONBD & + & -0.0002 & -0.16 & 0.0004 & 0.33 & 0.0011 & 0.71 \\
\hline$R E L$ & - & -0.2501 & $-4.11 * * *$ & -0.2028 & $-3.94 * * *$ & -0.1566 & $-2.44 * * *$ \\
\hline DOHOLDINGS & + & 0.0050 & $3.21 * * *$ & 0.0048 & $3.52 * * *$ & 0.0027 & $1.69 * *$ \\
\hline SEPCHR & + & 0.0517 & $1.28 *$ & 0.0818 & $2.32 * *$ & 0.0623 & $1.44 *$ \\
\hline LEADDIR & - & -0.0630 & $-1.53 *$ & -0.0404 & -1.14 & -0.0404 & -0.92 \\
\hline$B D S I Z E$ & + & 0.0753 & $1.54 *$ & 0.1124 & $2.59 * * *$ & 0.1147 & $2.21 * *$ \\
\hline NUMMTGS & + & 0.0641 & 0.87 & 0.0793 & 1.27 & 0.0244 & 0.31 \\
\hline COMPMIX & $?$ & 0.2839 & $4.13 * * *$ & 0.2847 & $4.74 * * *$ & 0.2264 & $3.15^{* * *}$ \\
\hline$L E V$ & $?$ & -1.4278 & $-11.04 * * *$ & -1.0536 & $-9.26 * * *$ & -1.0464 & -7.61 \\
\hline LnASSET & $?$ & -0.0799 & $-5.55 * * *$ & -0.1032 & $-8.58 * * *$ & -0.0791 & $-5.28 * * *$ \\
\hline Year controls & & \multicolumn{2}{|c|}{ Yes } & \multicolumn{2}{|c|}{ Yes } & \multicolumn{2}{|c|}{ Yes } \\
\hline $\begin{array}{l}\text { Industry } \\
\text { controls }\end{array}$ & & \multicolumn{2}{|c|}{ Yes } & \multicolumn{2}{|c|}{ Yes } & \multicolumn{2}{|c|}{ Yes } \\
\hline Observations & & \multicolumn{2}{|c|}{3008} & \multicolumn{2}{|c|}{3008} & \multicolumn{2}{|c|}{1992} \\
\hline F-Value & & \multicolumn{2}{|c|}{18.45} & \multicolumn{2}{|c|}{21.51} & \multicolumn{2}{|c|}{11.06} \\
\hline Adjusted $\mathrm{R}^{2}$ & & \multicolumn{2}{|c|}{$23.08 \%$} & \multicolumn{2}{|c|}{$24.28 \%$} & \multicolumn{2}{|c|}{$19.18 \%$} \\
\hline
\end{tabular}

1. Variable Definitions:

LnASSET $=\quad$ firm total assets; and

$L E V=\quad$ firm debt ratio (i.e., total debt/total assets); and

All other variables are defined in Table 1.

2. *** significant at 0.01 level, ** significant at 0.05 level, * significant at 0.10 level. Significance levels are based on one-tailed tests when the coefficient sign is predicted and on two-tailed tests otherwise. 


\section{Panel B: Governance Factors}

\begin{tabular}{|c|c|c|c|c|c|c|c|}
\hline \multirow[t]{2}{*}{ Variable } & \multirow{2}{*}{$\begin{array}{l}\text { Predicted } \\
\text { Sign }\end{array}$} & \multicolumn{2}{|c|}{ Current Tobin's $Q$} & \multicolumn{2}{|c|}{ Next year Tobin's $Q$} & \multicolumn{2}{|c|}{ Two years ahead Tobin's $Q$} \\
\hline & & Coeff. & $t$-stats & Coeff. & $t$-stats & Coeff. & $t$-stats \\
\hline Intercept & $?$ & 2.562 & $17.77 * * *$ & 2.448 & $19.66 * * *$ & 2.357 & $15.54 * * *$ \\
\hline$F B I$ & + & -0.001 & -0.90 & -0.001 & -0.80 & 0.001 & 0.43 \\
\hline$F B L$ & + & 0.06 & $1.93 * *$ & 0.075 & $2.46 * * *$ & 0.065 & $1.75^{* *}$ \\
\hline$F B S$ & + & 0.105 & $2.15 * *$ & 0.133 & $3.06 * * *$ & 0.137 & $2.66 * * *$ \\
\hline FOTH & + & 0.196 & $2.70 * * *$ & 0.205 & $3.30 * * *$ & 0.136 & $1.79 * *$ \\
\hline$L E V$ & $?$ & -1.424 & $-11.02 * * *$ & -1.042 & $-9.17 * * *$ & -1.044 & $-7.62 * * *$ \\
\hline LnASSET & $?$ & -0.077 & $-5.38 * * *$ & -0.101 & $-8.52 * * *$ & -0.075 & $-5.08 * * *$ \\
\hline Year controls & & \multicolumn{2}{|c|}{ Yes } & \multicolumn{2}{|c|}{ Yes } & \multicolumn{2}{|c|}{ Yes } \\
\hline $\begin{array}{l}\text { Industry } \\
\text { controls }\end{array}$ & & \multicolumn{2}{|c|}{ Yes } & \multicolumn{2}{|c|}{ Yes } & \multicolumn{2}{|c|}{ Yes } \\
\hline Observations & & \multicolumn{2}{|c|}{3008} & \multicolumn{2}{|c|}{3008} & \multicolumn{2}{|c|}{1992} \\
\hline F-Value & & \multicolumn{2}{|c|}{19.21} & \multicolumn{2}{|c|}{22.44} & \multicolumn{2}{|c|}{11.67} \\
\hline Adjusted $\mathrm{R}^{2}$ & & \multicolumn{2}{|c|}{$22.27 \%$} & \multicolumn{2}{|c|}{$23.47 \%$} & \multicolumn{2}{|c|}{$18.73 \%$} \\
\hline
\end{tabular}

1. Variable Definitions:

$F B I=\quad$ board independence factor $(0.686 * P C T O N B D-0.749 * D O H O L D I N G S-0.718 * R E L)$;

$F B L=\quad$ board leadership factor $(0.782 * S E P C H R-0.682 * L E A D D I R)$;

$F B S=\quad$ board size factor $(0.901 * B D S I Z E)$;

FOTH $=\quad$ other board factor $(0.896 * N U M M T G S+0.431 * C O M P M I X)$;

LnASSET $=\quad$ firm total assets; and

$L E V=\quad$ firm debt ratio (i.e., total debt/total assets); and

All other variables are defined in Table 1.

2. *** significant at 0.01 level, $* *$ significant at 0.05 level, * significant at 0.10 level. Significance levels are based on one-tailed tests when the coefficient sign is predicted and on two-tailed tests otherwise. 


\title{
FAMILY BUSINESS, DIRECTOR COMPENSATION AND BOARD EFFICACY: THE CASE OF TAIWAN
}

\author{
Tsun-Jui Hsieh*, Yu-Ju Chen**
}

\begin{abstract}
This paper investigates the impact of outside directors on firm performance during legal transitions and examines how the roles of family business and director compensation influence board efficacy. By using Taiwanese listed companies as our sample, the empirical results show that outside directors who are appointed by legal mandate have less positive impacts on firm performance than outside directors appointed voluntarily. Family business weakens the positive impact of outside director on firm performance. The evidence further suggests that director compensation contributes to firm performance, particularly when outside directors are voluntarily appointed. The findings provide western managers with an understanding of how the typical Chinese family business affects board independence. We also demonstrate and incorporate the cultural and the ownership characteristics into the analysis to present a country-specific pattern that should be informative for foreign investors who are concerned about the quality of corporate governance in East Asia.
\end{abstract}

Keywords: Corporate Governance, Outside Director, Family Business, Director Compensation

${ }^{*}$ Corresponding Author, Department of International Business, Providence Vniversity, Address: 200, Chungchi Rd., Shalu, Taichung, Taiwan 433

Tel.: 886-4-2632 8001 ext. 13119

E-mail: tjhsieh@pu.edu.tw

स* Department of Finance, National Changhua University of Education, Address: 2, Shi-Da Rd., Changhua City, Taiwan

Tel.: 886-4-7232105 ext. 7328

E-mail: yujuchen@cc.ncue.edu.tw

\section{Introduction}

Much attention has been directed toward corporate governance reforms on the part of both theorists and practitioners, particularly following major corporate scandals such as Enron and WorldCom in the United States. Although a number of studies have investigated why such business empires collapses, consistent explanations are lacking. Some scholars (e.g., Dewing and Russell, 2004) suggest that the scandals occurred partly because of the lack of corporate disciplines and partly because of the insufficiency of market prescriptions. Other scholars (e.g. Clement, 2006) explore the American corporate scandals from the business ethics perspective. Being aware of the leakages of institutional regulations, many countries have subsequently started to initiate or reinforce their corporate governance systems to prevent such kinds of scandals from happening again.

The initiatives behind the corporate governance reforms often stem from responses to various imperatives, such as corporate raids, capital market globalization, and intentions to enhance investor confidence (Rhee and Lee, 2008). For example, Taiwan, as an emerging country in East Asia, seeks to upgrade her weak legal systems ( $\mathrm{La}$
Porta, Lopez-de-Silances, Shleifer and Vishny, 1997) to an extent which complies with international corporate governance standards. Therefore, the Taiwan Stock Exchange (TSE) has taken steps to improve the quality of corporate governance. One of the primary policies that the TSE has initiated is to request initial public offering (IPO) companies from 2002 onwards to introduce at least two independent outside directors (henceforth referred to as outside directors) to their boards before they are permitted to be listed.

However, it remains an open question whether outside directors appointed by legal mandate are effective in enhancing corporate values. Although there have been many studies that investigate the relationships between the presence of outside directors and firm performance, a paucity of literature detracts from investigating the efficacy of outside directors based on the condition of legal mandate. Many scholars suggest that there is a connection between directors and firm performance (e.g., Luan and Tang, 2007; Kumar and Zattoni, 2013; Peng 2004; Peng, Buck and Fliatotchev, 2003). Peng (2004) finds that outside directors do have a positive effect on firm performance measured in terms of sales growth, while they have insignificant impact as measured by the return on 
equity. Similarly, Luan and Tang (2007) further confirm the positive impact of independent directors on firm performance. But, to date, little attention has been directed to enhancing our understanding of the differences of efficacy of outside directors who are appointed by voluntariness of companies themselves or by legal mandate.

Given that, this study aims to investigate whether Taiwan's corporate governance reforms on board independence have a positive influence on firm performance arising from legal requirements to appoint outside directors. Since family business is a dominant form of business organization and has highly concentrated ownership structure in Taiwan (Luo and Chung, 2005), understanding the influence of Chinese family business on the board of directors is paramount. Thus, this study will also explore how family business influences board efficacy and the effects of director compensation on firm performance in light of different motivations firms appoint board of directors.

The empirical results suggest that outside directors appointed voluntarily will have a positive effect on firm performance, while outside directors introduced to the boards by legal mandate will have relatively weak impact on firm performance. We also find that family business characteristics hindering the impact of outside director on firm performance. Although many studies suggest that director compensation is positively related to firm performance (Brick, Palmon and Wald, 2006), the results extend our knowledge by depicting that director compensation has relatively weak effects in circumstances where outside directors are appointed by legal mandate.

\section{Corporate governance development in Taiwan}

The consensus for improving corporate governance is rapidly prevalent in Taiwan through both ways from corporate self-discipline and from official policy enforcement. For the past two decades, Taiwan has ever been criticized for her lack of comprehensive legal system to increase financial transparency and to reduce the analyst bias (La Porta, Lopez-de-Silanes and Shleifer, 1999). Pubic opinions thus urge the government to initiate legal reforms to protect investors' wealth. Furthermore, ownership structure is also an important factor that worsens the corporate governance quality. Yeh et al. (2001) identified $70 \%$ of Taiwanese listed companies are controlled by families or their owners. This feature has led to the prevalent phenomenon that the owner family is usually also serving as the CEO, and the selection of directors is probably decided by their personal relationships with the owners rather than in accordance with their expertise, which cause severe business ethics issues.

Business groups, a dominant form of business organization in Taiwan business system, are paramount to Taiwan's economic growth. They contribute about 54 percents to Taiwan's GDP (Chu, 2004). Thus, such form of organization cannot be ignored when addressing the nature of corporate governance system in Taiwan. Member firms in business groups are commonly linked through equity shareholdings (La Porta et al., 1999), and the group at the center often exercises strategic control over the affiliates through interlocking directorates of family members. These cross-directorate relationships may provide a channel through which the group can expropriate minority shareholders' interests. For example, the group at the center may benefit from arbitrage among affiliates through "tunneling," which has been described as transferring resources from one affiliate in which the controlling family has few cash flow rights to other affiliates in which it has considerable cash flow rights (Bertrand, Mehta, and Mullainatha, 2002). Such agency issues have been existed for many years in Taiwan and become the driving force behind improving the effectiveness of corporate boards.

Given the escalating emphasis on the effectiveness of corporate boards, many studies find that the boards of directors may become dysfunctional when exercising their duties. For example, Jensen (1993) claims that boards of directors are limited to fulfill their responsibilities effectively because the board culture may discourage team conflicts that inhibit directors from speaking up in the board meetings. This argument may be applicable to Taiwanese family business system in which group harmony is emphasized because of the coherent kinships or friendships. Such ineffectiveness of board directors has caused many financial and managerial scandals in Taiwan (Lee and Yeh, 2004), and the exploitation will not be lessened unless the corporate governance mechanism can be upgraded.

In order to tackle the increasing agency problems and respond to the escalating competitions following Taiwan's entrance to the World Trade Organization, it is even more urgent for Taiwan to initiate corporate governance reforms to catch up with international corporate governance standards and face the challenges presented by the global markets. In this sense, the Securities and Futures Commission (SFC) in Taiwan has attempted to implement institutional reforms by introducing recommendations: (i) to protect shareholders' rights and interests; (ii) to strengthen the powers of the board of directors; (iii) to enable supervisors to fully exercise their roles; (iv) to respect stakeholders' rights and interests; and (v) to enhance information transparency. Based on these 
recommendations, the TSE amended the listing rules to formally request that at least two outside directors should be appointed onto the boards when companies seek to be listed on the stock exchange from 2002 and should keep maintaining at least two outside directors on the board. Hence, Taiwan presents an appropriate research setting to understand the efficacy of corporate governance reforms during legal transitions.

\section{Hypotheses}

\section{Voluntary vs. Mandatory Directors}

According to the "Corporate Governance BestPractice Principles for TSE/GTSM Listed Companies" issued by the TSE, any companies seeking to be listed on the stock exchange are mandated to appoint at least two outside directors onto their boards. Although these new listing rules become effective in 2002, there are companies which are listed before 2002 and not restricted by new listing rules but remain voluntarily appointing outside directors onto their boards. In the absence of legal mandate, such voluntary actions imply that these companies have the intentions to reform their board structures and thus to improve their corporate governance since they are not requested by the law to do that. Under this circumstance, outside directors appointed voluntarily can exert their duties without inappropriate interventions from the CEO or large shareholders since the primitive objectivity of their appointments is to help the firm enhance firm performance. Therefore, this study argues that companies that voluntarily appoint outside directors to their boards might have more of an intention than other firms to improve the corporate governance quality, and outside directors are able to independently review and monitor management's operations and promote firm performance (Luan and Tang, 2007).

By contrast, companies listed on the stock exchange after 2002 had to follow the new listing rules which request IPO firms to introduce at least two outside directors to the boards. Following the new listing rules, companies employ outside directors who are qualified nominally based on the criteria issued by the TSE. However, how much the outside directors are independent and how much they are able to exercise their obligations is a question. In the real world, their presence on the boards may be just for meeting the bottom-line standard of corporate governance and thereby comply with the legal requirements to make the companies successfully listed. The selection of outside directors in such instances cannot avoid the influences of guanxi in the Chinese cultural contexts (Fan, 2002). Outside directors, thus, are nominally qualified to be independent on the boards but they are indeed having personal connections with their nominators directly or indirectly. Whether they have the expertise for monitoring or have ties for organizational boundary spanning (Luan and Tang, 2007; Peng, 2004) are not the points in the priority that the companies concern about. For this reason, outside directors might be reluctant to take a stance that goes contrary to management and even fail to bridge the companies to accessing the external resources. To sum up, this study argues that outside directors who are appointed by legal mandate will have a less positive impact on firm performance than those who are appointed voluntarily.

Hypothesis 1: The proportion of outside directors appointed on the boards by legal mandate has a less impact on firm performance than that of outside directors appointed voluntarily.

\section{Family Business}

Family business is a dominant form of business organizations in Taiwan (Chen, Yen, Fu and Chang, 2007; Luo and Chung, 2005, Wu, 2006; Yeh et al., 2001). These studies point out that the firms in Taiwan are usually controlled directly or indirectly by their founding families. Traditionally, the founder, who is also the owner, builds the enterprise and expands the scope of the business in his own way. While the power of the family was transited to the subsequent generations or the outsiders, the founding families still can hold the majority of shares and large proportion of board seats (Yeh, 2005; Yeh et al., 2001) to direct the companies' operations.

The distinctive features of Chinese family business can be broadly categorized by ownership structure and information asymmetry. Filatotchev et al. (2005) suggest that family ownership structure generates effects pro and con on firm operations. Generally, family business can reduce agency costs between owners and managers and thus enhance firm performance. However, family business also is criticized for their exploitation of the wealth of minority shareholders (La Porta et al, 1999) and for their weak financial transparency (Gul and Leung, 2004). To maximize family wealth, family businesses may keep all information in family (Luo and Chung, 2005). Outsiders are difficult to know the whole real operations even on the seat of the board. Considering the power of family business, we suggest that the positive impact of outside directors on firm performance will be mitigated.

With these regards, we argue that outside directors appointed will improve the quality of corporate governance and further to enhance firm performance. Unlike the separation of ownership and management in widely-held companies, family business is a distinct form of business organization, and in Chinese society, business is part of the family's private assets or property is widely 
accepted (Hamilton, 1998) so that managerial positions are occupied by family members who have close kinships with the controlling family. Compared with widely-held companies, family involvements are able to reduce agency costs (Zahra, 2003). This is to say, the conflict between the manager and the family members is not severe because of the alignments of interests between owners and managers (Filatotchev et al., 2005). That explains why outside directors in the family business are less important than the widely-held companies since the primary purpose of outside directors is to monitor whether the business decisions of the manager are aligned with the interest of the shareholders. However, as the manager of family business is the same as the owner who has common interest, thus, even if the outside director is employed by the family, the influence to the business efficiency is not as prominent as that of the outside directors of the widely-held companies.

Concerning the second future of Chinese family business, many scholars suggest that all information keeping in the family is more salient in the Chinese family business ( Luo and Chung, 2005; Pye, 1985). The founding family builds up the business and forms the inner circle to control and manage the business (Hamilton, 1998). In an earlier work, Pye (1985: 70) states that "The Chinese were taught to recognize a vivid distinction between family members, who could be relied upon, and non-family people, who are not to be trusted except in qualified ways." In the previous studies, Luo and Chung (2005) argue that social relationships in Chinese society are structured in concentric circles, with family members in the innermost circle and strangers in the outer circle. The remarks indicate family connections are the closest relationships in the organization that outsiders are not easy to participate in the decision formation of such core circle. Similarly in Korea, Chang (2003) argues that family may use insider information to increase their shares in successful business group affiliates through exploiting wealth of outsiders. Thus, family erects a wall to separate outsiders from their cores. Non-family member or outsiders lack affinity and blood relationships that make them hardly obtain insider information and exercise their duties successfully. Outside directors, as they are outsiders, may not able to obtain critical information from family business to make effective suggestions or monitoring on the boards. Hence, the following hypothesis is formulated:

Hypothesis 2: The proportion of outside directors appointed by a family business has a less impact on firm performance than that of outside directors appointed by a non-family business.

\section{Director Compensation}

Director compensation reflects the value added to companies by directors' decisions. Unattractive compensation may not be able to motivate directors to maximize shareholder value (Felo, 2001; McClain, 2012). Drawing on optimal contracting theory (e.g., Gaver and Gaver, 1995), compensation policy is set up in accordance with the values which the directors can create. In a recent study, Young and Tsai (2008) argue that compensation can motivate nonfamily CEO to utilize their social capital in executing corporate operations. In a similar vein, Linn and Park (2005) suggest that outside directors must be rewarded accordingly if they view their efforts costly, otherwise they will not take the job. The compensation also influences whether the directors can commit to exercise their duties. Although compensation packages are designed differently among companies, it is a general consensus that providing appropriate incentives can encourage directors to act in the interests of shareholders (Linn and Park, 2005).

Based on the importance of the compensation incentives discussed above, the next question is whether the impact of director compensation on firm performance is influenced by the two forms of outside directors. Previous research argues that board compensation is positively associated with firm performance (e.g., Crespí-Cladera and Gispert, 2003), we also suggest that compensation has greater incentive effects when outside directors are appointed voluntarily. This can be interpreted that companies voluntarily appointing outside directors onto their boards explicitly show their intentions to enhance firm performance by improving their corporate governance mechanism. Since firms intend to enhance their performance by appointing outside directors, the voluntary outside directors can exercise their duties independently with relatively low level of intervention. Building on the above work, we can conclude that the better performance the firm achieves, the higher level of compensation the directors receive. The level of compensation induces them to maximize their efforts by supervising and providing suggestions to enhance firm performance.

The mandatory outside directors are appointed by legal requirements. In most instances, given that this type of outside director is compulsorily nominated, companies tend to introduce those who nominally meet the qualifications that are required of an outside director, but they may not wholeheartedly expect the outside directors to vigilantly monitor the firm while on the board. Hence, board efficacy will decline because, for conforming to legal requirements, the CEO tends to nominate new directors who are indebted for their appointments, which undermines board independence (Ryan and Wiggins III, 2004). 
Additionally, Brick, Palmon and Wald (2006) state that well-compensated directors have a lower inclination to "rock the boat." Thus, mandatory outside directors will be conservative in providing constructive criticism to the board. In this sense, although they are referred to as "independent" outside directors, their nominations might be initiated by legal requirements to help IPO firms be successfully listed. The compensation incentive effects should be relatively weak for outside directors appointed by legal mandate. The following hypothesis is formulated:

Hypothesis 3: The association between outside director compensation and firm performance will be less pronounced as outside directors are appointed by legal mandate.

\section{Methods}

\section{Sample and Data}

The data used to test the hypotheses is drawn from 2002 and 2003 annual reports of Taiwanese listed companies and the database maintained by the Taiwan Economic Journal (TEJ). The TEJ is the most prestigious database in academic research in Taiwan and is widely subscribed to by many international research agencies including Datastream and Reuters. The data we used spans only two years, due to the lack of data on individual director compensation from 2004. The new listing rule, requesting IPO firms appointing at least two outside directors on the board, became effective in 2002.

There are two types of outside directors in this study. One is outside directors who are voluntarily appointed without any legal mandate. The other type is outside directors whose companies were initially listed in 2002 or later since they were appointed after the new legal requirements took effect. In addition to identifying the types of the outside directors, the annual reports also provide information regarding the directors' compensation. This paper has drawn on annual reports to obtain data including details of outside directors and director compensation. The data for the remaining variables are obtained from the TEJ database. After cross-checking the information regarding the selected variables from both the annual reports and the TEJ database, a total of 1,686 observations are included in the sample to test our hypotheses.

Our sample includes 1,686 companies. There are a total of 810 companies in 2002, including 666 initially listed before 2002 and 134 initially listed in 2002. Similarly, 876 companies are included in 2003, consisting of 664 companies initially listed before 2002, 121 companies initially listed in 2002 and 101 companies initially listed in 2003. The sample set shows that $21 \%$ of the sample companies are listed after 2002, which are requested by legal mandate to appoint at least two outside directors to the boards.

\section{Model Specification}

We use the following multiple regression to test our hypotheses. To be consistent with our hypotheses, we predict that the coefficient estimate of $O U T D I R^{*} L M$ is negative (H1), and the coefficient estimates of $O U T D I R^{*} F A M I L Y$ and $C O M P E N^{*} L M$ are negative (H2 and $\mathrm{H} 3$ ). Definition of each variable is addressed in next section.

Tobin's $Q_{i t}=\beta_{0}+\beta_{1}$ OUTDIR $_{i t}+\beta_{2} L_{i t}+$ $\beta_{3}$ OUTDIR $_{i t} * L M_{i t}+\beta_{4}$ FAMILY $_{i t}+\beta_{5}$ OUTDIR $_{i t}$ $* F A M I L Y_{i t}+\beta_{6}$ COMPEN $_{i t}+\beta_{7}$ COMPEN $_{i t} * L M_{i t}+$ $\beta_{8}$ DEVATION $_{i t}+\beta_{9}$ BOARDSIZE $_{i t}+\beta_{10}$ CEODUA ${ }_{i t}+\beta_{11} S_{I Z E_{i t}}+\beta_{12} L E V_{i t}+\beta_{13} A G E_{i t}+$ Industry control $_{i}+$ Year control $_{t}+\varepsilon_{i t}$

\section{Measures}

The dependent variable, Tobin's $Q$, is used to measure firm performance (e.g., Yeh, 2005), measured by the replacement cost of the assets divided by the book value of the assets. Due to the lack of replacement cost data, we gauge it as the market value of the assets divided by the book value of the assets (for a similar approach, see Lehn et al., 1990 and Yeh, 2005). Outside director (OUTDIR) is measured by the number of outside directors divided by the total number of board members. The number of outside directors is calculated based on the total number of board members according to the qualifications that TSE required. Dummy variable $(L M)$ is set, coded as 1 , if firms are initially listed in and after 2002 since these firms are requested by legal requirements to appoint outside directors on the boards. Family (FAMILY) is coded as 1 when the firm's CEO is the founding family members and when family members hold over half the total board seats (e.g., Tsai, Hung, Kuo and Kuo, 2006), otherwise 0. Director compensation often consists of a package of bonus and cash (Cordeiro, Veliyath and Eramus, 2000). In Taiwan, the annual reports of listed companies are used to piece together all kinds of compensation into a total cash amount disclosed in the financial reports. Consequently, outside director compensation (COMPEN) is measured as the average amount of total bonus and salaries received by each outside director divided by the firm's total assets, in which the stock-based compensation is counted by multiplying the number of bonus shares by the stock price on the day when the annual shareholder meeting was held.

To control for some potential confounding effects, several control variables are included. Prior studies suggest that agency problems influences firm performance. La Porta et al. (1999), 
Claessens, Djankov and Lang (2002) and Yeh et al. (2001) point out the existence of agency problems arising from the divergence between the controlling and the minority owners. Yeh et al. (2001) suggest that as the divergence between the controlling and the minority owners escalates, firm performance will become worse. In this sense, we control for the divergence between the controlling and the minority owners and define DEVATION as the controlling rights minus the cash flow rights. Furthermore, board size and CEO duality also affect firm performance (e.g., Yermack, 1996). We control for board size(BOARDSIZE), defined as the number of directors who have been appointed on the board, and CEO duality, measured as a dummy variable $(C E O D U)$, coded as 1 when $\mathrm{CEO}$ is also the chairman, otherwise 0. Firm size (SIZE) is measured as the logarithm of firm sales. Firm leverage $(L E V)$ is measured as debt divided by sales. Firm age $(A G E)$ is measured as the number of years the firm had been in operation. Firm performance will be influenced by a firm's initial public offerings. After a firm goes public, its performance will decline (Kim, Kitsabunnarat and Nofsinger, 2004). Finally, industry membership and year are also controlled as dummy variables. Year control includes a set of dummy variables representing the fiscal year; Industry control includes a set of dummy variables representing the industry.

\section{Results}

Table 1 presents the descriptive statistics, including the means, standard deviations and Pearson correlation matrices of all the variables used. The average of the number of outside directors divided by total number of board members is 0.06 . The mean of Tobin's Q is 1.29. The mean of LM equals 0.21 , indicating that twenty one percent of the firms are requested by law to appoint outside directors on the boards. Fifty eight percent of the sample firms is family businesses. In order to examine the multicollinearity between the variables, the procedure proposed by Neter et al. (1985) was used to calculate the VIF (variance inflation factor) values and the results suggest that there was no problem due to multicollinearity with all the VIF values being less than 10 .

Table 1. Descriptive Statistics and Pearson Correlation Coefficients

\begin{tabular}{|c|c|c|c|c|c|c|c|c|c|c|c|c|c|}
\hline & Variable & Mean & S.D. & 1 & 2 & 3 & 4 & 5 & 6 & 7 & 8 & 9 & 10 \\
\hline 1 & Tobin's Q & 1.29 & 0.63 & & & & & & & & & & \\
\hline 2 & OUTDIR & 0.06 & 0.12 & $0.30 * * *$ & & & & & & & & & \\
\hline 3 & LM & 0.21 & 0.41 & $0.37 * * *$ & $0.50 * * *$ & & & & & & & & \\
\hline 4 & FAMILY & 0.58 & 0.49 & $-0.22 * * *$ & $-0.26 * * *$ & $-0.25 * * *$ & & & & & & & \\
\hline 5 & COMPEN & 0.00 & 0.00 & $0.03 *$ & $0.07 * * *$ & $0.05^{* *}$ & -0.02 & & & & & & \\
\hline 6 & DEVATION & 0.04 & 0.08 & $0.06 * *$ & -0.01 & $0.08 * * *$ & $0.18 * * *$ & -0.02 & & & & & \\
\hline 7 & BOARDSIZE & 6.82 & 2.58 & -0.04 & -0.04 & $-0.03 * *$ & $-0.08 * *$ & 0.02 & $0.16 * *$ & & & & \\
\hline 8 & CEODUA & 0.37 & 0.48 & $0.04 *$ & $0.11 * * *$ & $0.05 * *$ & $-0.04 * *$ & 0.01 & $-0.17 * * *$ & $-0.19 * * *$ & & & \\
\hline 9 & SIZE & 21.61 & 1.37 & $0.12 * * *$ & $-0.06 * * *$ & $-0.11 * * *$ & $0.07 * * *$ & 0.00 & $0.13 * * *$ & $0.28 * * *$ & $-0.13 * * *$ & & \\
\hline & LEV & 0.42 & 0.17 & $-0.24 * * *$ & $-0.05 * *$ & $-0.06^{* *}$ & $-0.05 * *$ & 0.01 & $-0.12 * * *$ & -0.00 & -0.01 & $0.14 * * *$ & \\
\hline & AGE & 23.83 & 11.78 & $-0.32 * * *$ & $-0.22 * * *$ & $-0.37 * * *$ & $0.31 * * *$ & 0.02 & $-0.08 * * *$ & $0.23 * * *$ & $-0.14 * * *$ & $0.15 * * *$ & $0.07 * *$ \\
\hline
\end{tabular}

Significance level: *** indicates $P<0.01$; ** indicates $P<0.05$; * indicates $P<0.1$

Table 2 shows the results of analyses to test our hypotheses. The results of Model 1 show the coefficient on OUTDIR (outside director) to be positive $(0.745)$ and statistically significant $(P$ value $<0.01)$ while the coefficient on OUTDIR $\times$ LM (outside director $\times$ legal mandate) is negative($0.615)$ and significant $(P$ value $<0.01)$. The empirical evidence suggests that outside directors have positive effects on firm performance but if outside directors are appointed by legal mandate, the performance effects will diminish. Hypothesis 1 is supported.

In Model 2, we consider the family business effects. The coefficient on OUTDIR $\times$ FAMILY (outside director $\times$ family business) is negative ($0.548)$ and significant $(P$ value $<0.05)$, indicating that the impact of outside directors on firm performance will be mitigated when outside directors are appointed by family business. Hypothesis 2 is supported. In order to test
Hypothesis 3, we conduct additional analysis by entering compensation data. In Model 3, the results show that Hypothesis 3 is supported. The coefficient on COMPEN (director compensation) is positive (7.687) and insignificant while the coefficient on COMPEN $\times$ LM (director compensation $\times$ legal mandate) is negative $(-2.439)$ and significant $(P$ value $<0.05)$. The results indicate that director compensation has less incentive impacts on firm performance when outside directors are appointed by legal mandate.

As for the control variables, LM, and SIZE show positive relationships with firm performance, indicating that legal mandate, large firm size and initial public offerings have positive impacts on firm performance. In contrast, LEV and AGE show a negative relationship with firm performance, indicating that high debt ratio and being older firms have negative impacts on firm performance. 
Table 2. Results of Multiple Regression Analyses

\begin{tabular}{|c|c|c|c|}
\hline \multirow{2}{*}{ Variable } & \multicolumn{3}{|c|}{ Tobin's Q } \\
\hline & Model 1 & Model 2 & Model 3 \\
\hline \multirow{2}{*}{ Constant } & -0.219 & -0.265 & -0.265 \\
\hline & $(0.259)$ & $(0.169)$ & $(0.170)$ \\
\hline \multirow{2}{*}{ OUTDIR } & 0.745 & 1.099 & 1.081 \\
\hline & $(0.000)^{* * *}$ & $(0.000)^{* * *}$ & $(0.000)^{* * *}$ \\
\hline \multirow{2}{*}{$\mathrm{LM}$} & 0.381 & 0.364 & 0.362 \\
\hline & $(0.000)^{* * *}$ & $(0.000)^{* * *}$ & $(0.000)^{* * *}$ \\
\hline \multirow{2}{*}{ OUTDIR $\times$ LM } & -0.615 & -0.562 & -0.556 \\
\hline & $(0.006)^{* * *}$ & $(0.012)^{* *}$ & $(0.014)^{* *}$ \\
\hline \multirow{2}{*}{ FAMILY } & & 0.130 & 0.131 \\
\hline & & $(0.000)^{* * *}$ & $(0.000)^{* * *}$ \\
\hline \multirow{2}{*}{ OUTDIR $\times$ FAMILY } & & -0.548 & -0.540 \\
\hline & & $(0.024)^{* *}$ & $(0.026)^{* *}$ \\
\hline \multirow{2}{*}{ COMPEN } & & & 7.687 \\
\hline & & & $(0.516)$ \\
\hline \multirow{2}{*}{ COMPEN $\times$ LM } & & & -2.439 \\
\hline & & & $(0.049)^{* *}$ \\
\hline \multirow{2}{*}{ DEVATION } & -0.189 & -0.326 & -0.325 \\
\hline & $(0.176)$ & $(0.022)^{* *}$ & $(0.022)^{* *}$ \\
\hline \multirow{2}{*}{ BOARDSIZE } & -0.007 & -0.004 & -0.004 \\
\hline & $(0.136)$ & $(0.426)$ & $(0.417)$ \\
\hline \multirow{2}{*}{ CEODUA } & -0.014 & -0.014 & -0.014 \\
\hline & $(0.551)$ & $(0.570)$ & $(0.562)$ \\
\hline \multirow{2}{*}{ SIZE } & 0.093 & 0.091 & 0.091 \\
\hline & $(0.000)^{* * *}$ & $(0.000)^{* * *}$ & $(0.000)^{* * *}$ \\
\hline \multirow{2}{*}{ LEV } & -0.773 & -0.742 & -0.741 \\
\hline & $(0.000)^{* * *}$ & $(0.000)^{* * *}$ & $(0.000)^{* * *}$ \\
\hline \multirow{2}{*}{$\mathrm{AGE}$} & -0.011 & -0.011 & -0.011 \\
\hline & $(0.000)^{* * *}$ & $(0.000)^{* * *}$ & $(0.000) * * *$ \\
\hline Industry control & Not reported & Not reported & Not reported \\
\hline Year control & Not reported & Not reported & Not reported \\
\hline $\mathrm{N}$ & 1686 & 1686 & 1686 \\
\hline $\mathrm{F}$ & 34.236 & 33.015 & 31.046 \\
\hline Adjusted $\mathrm{R}^{2}$ & $30.2 \%$ & $32.6 \%$ & $35.1 \%$ \\
\hline
\end{tabular}

Tobin's Q the market value of equity plus the book value of the debt divided by the book value of the assets

OUTDIR the number of outside directors divided by the total number of board members

LM $\quad 1$ if the firms are initially listed in and after 2002, otherwise 0.

FAMILY $\quad$ lif the firm's CEO is the founding family members and when family members hold over half the total board seats

COMPEN average amount of total bonus and salaries received by each outside director divided by the firm's total assets

DEVATION the controlling rights minus the cash flow rights

BOARDSIZE the number of directors on the board

CEODUA 1if CEO is also the chairman, otherwise 0.

SIZE logarithm of total sales

LEV debt divided by asset.

AGE the number of years the firm has been in operation

1. The number in parentheses is $\mathrm{p}$ value. Significance level: *** indicates $\mathrm{P}<0.01$; ** indicates $\mathrm{P}<0.05$;

* indicates $\mathrm{P}<0.1$.

2. All the VIF values are less 10 and the results suggest no problem of multicollinearity。

To further investigate the robustness of our empirical results, we conduct sensitivity analyses to consider the IPOs effects (initial public offering) on firm performance. We set a dummy variable IPOs 
equal to one if the firm is an IPO firm in a given year, otherwise 0 . Untabulated results show that the results are similar to those reported in our main analyses, reported in Table 2 . Thus, the results are not attributable to the IPOs effects. The sensitivity test is also conducted with alternative time specification for director compensation data can only be obtained for two years. Without considering the director compensation data, we extend the sample time window from two years (2002 to 2003) to five years (2002 to 2006). Hence, a new set of 5,608 observations is developed and the hypothesis 1 and 2 are re-tested. The results, shown in Table 3, are similar to those reported in our main analyses, reported in Table 2.

\section{Discussions}

This paper aims to answer the research questions: (1) do outside directors appointed by voluntariness or by legal mandate generate different impacts on firm performance; (2) how do family businesses moderate the relationships between outside directors and firm performance; and (3) are the impacts of director compensation on firm performance influenced by the different motivations of firms. In general, the empirical results support our hypotheses. Prior studies have suggested that outside directors on the board would have significant effects on the firm performance (e.g., Luan and Tang, 2007; Shleifer and Vishny, 1997). This study further extends the current research progress by simultaneously considering the impacts of family business and director compensation during legal transitions. The results suggest that outside directors contribute unequally to firm performance when we classified outside directors into two types in accordance with their appointments by corporate voluntariness or by legal mandate.

The findings clearly suggest that outside directors voluntarily appointed by companies have greater positive contributions to firm performance, while those appointed for the sake of complying with legal requirements have a relatively slighter effect on firm performance. The findings indicate that even though the government has done a lot to promote corporate governance, corporate governance is still a very new concept and is in a preliminary development stage in many companies. Indeed, to many senior managers, the launch of corporate governance means increased restriction and monitoring. Therefore, if there are any mandatory regulations on corporate governance, companies may comply to meet the legal requirements, but outside directors, in this condition, will probably be symbolic figures rather than taking an actual monitoring role. In other words, a company appointing outside directors by legal mandate indicates that the appointments are not totally by corporate voluntariness so that the efficacy of outside directors may be limited or even detrimental to firm performance.

The findings also suggest that family businesses negatively moderate the relationship between outside director and firm performance. Family businesses are the dominant business system in Taiwan, and ownership is highly concentrated in the founding family (Luo and Chung, 2005; La Porta et al., 1999). Such concentrated ownership enables the founding family to occupy the majority of board seats. The core leader of the founding family usually assigns the family members to the key managerial positions. These family-related managers have blood relationship with the founding family (Luo and Chung, 2005). Even though outside directors are recruited to the board of a family business, the decisions of the family business are made mostly by family members, which outside directors find it difficult to monitor and become involved with, because they are the outsiders and not included in the inner circle of the family. Hence, the findings may be interpreted that outside directors in a family business are appointed largely for social legitimacy and to comply with the institutional needs (DiMaggio and Powell, 1983). Family businesses appointing outside directors can enhance their corporate image, showing the public and the investors a signal that they begin to dilute their familism by introducing outside directors on the boards (Rhee and Lee, 2008).

The findings show that the impacts of directors' compensation on firm performance are moderated by the different types of outside directors. Outside directors are rewarded for their efforts in terms of serving the board. However, the empirical evidence suggests that the incentive effects of compensation are more significant for voluntary outside directors. Companies which voluntarily appoint outside directors indicate the intention to improve the quality of corporate governance and probably want the best directors serving on their boards. Inadequate compensation is unlikely to attract and retain outstanding directors to fulfill the objectives of such companies. Young and Tsai (2008) suggest that compensation can induce nonfamily CEOs to utilize their social capital while family CEOs' social capital is not incentive-relevant because of their alignments of owner-managers ownership. Our results suggest that director compensation can encourage voluntary outside directors to promote corporate values, indicating higher compensation can attract better directors and also motivate the directors to improve firm performance.

Mandatory outside directors are appointed by legal mandate. The results suggest that the incentive effects of compensation are not as pronounced as with voluntary outside directors. Since the main 
purpose of appointing outside directors is to meet legal requirements, the incentive effects are thus eroded. Similar to the findings of Brick, Palmon and Wald (2006), excess compensation is symptomatic of cronyism, where directors fail to protect the wealth of shareholders. Our results imply that excess compensation weakens directors' monitoring, which in turn undermines firm performance. This may be interpreted that outside directors are usually nominated by the CEO or the board chair, and they are sensitively aware of the fact that they owe their positions to the CEO or the board chair. Thus, director compensation loses its function of serving as an inducement to encourage mandatory outside directors to improve firm performance.

Table 3. Results of Sensitivity Analyses

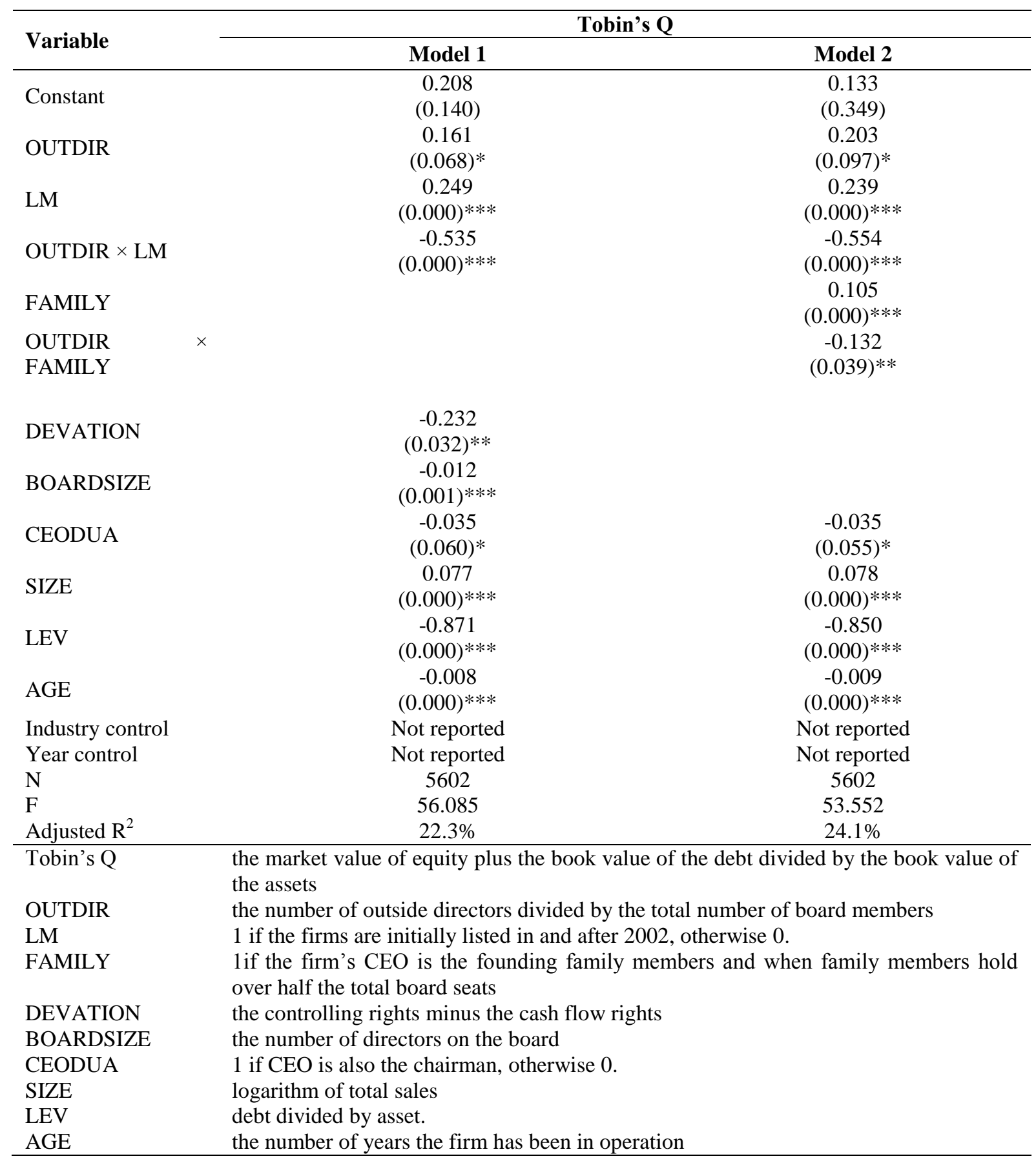

1. The number in parentheses is $\mathrm{p}$ value. Significance level: *** indicates $\mathrm{P}<0.01$; ** indicates $\mathrm{P}<0.05$; $*$ indicates $\mathrm{P}<0.1$.

2. All the VIF values are less 10 and the results suggest no problem of multicollinearity。 


\section{Implications for Theory and Practice}

Several implications both for theory and practice can be drawn from this study. Prior research on the efficacy of outside directors does not distinguish the motivations by which outside directors are appointed (e.g. Luan and Tang, 2007). This study goes beyond the existing literature by extending the study of the efficacy of board independence to the extent which considers the appointments of outside directors to the boards by corporate voluntariness or by legal mandate. This is an important finding that supplements the conventional arguments which based on agency theory to interpret the failure of outside directors on the board. The results indicate that companies appointing outside directors may not really intend to improve the quality of corporate governance but just to comply with the pressure of external institutional forces. This is an implicit ethical phenomenon regarding how firms respond to legal requirements on corporate governance and our findings can offer a theoretical perspective to explain why outside directors fail to be effective by pointing out the firms' unethical pretence to have outside directors only for institutional legitimacy. This study also made contributions to family research by shedding light on the impact of family control on the efficacy of outside directors during legal transitions in corporate governance reforms. The findings indicate that the controlling family presents a defensive attitude towards outsiders. Following the logic of Luo and Chung (2005), the controlling family holds inner information and tends to "keep it all in the family." In this sense, family control makes outside directors less contributable to firm performance.

For practical implications, the findings of this study show that outside directors appointed by legal mandate cannot function well as they are expected to. On reflection, corporate governance reforms on board independence should be further developed. Policy-makers may not neglect the potential problems that "masked" outside directors may nominally conform to legal requirements but their existence may cripple the effectiveness of the corporate board and consequently erode the firm's value. Western managers can also benefit from this study by learning how the typical Chinese family business affects board independence. This paper considers the prevalent family features of Chinese businesses and finds that family factors counteract the effectiveness of outside directors. We demonstrate and incorporate the cultural and the ownership characteristics into analysis to present a country-specific pattern that should be informative for foreign investors (Rhee and Lee, 2008) who are concerned about the quality of corporate governance in East Asia.

\section{References}

1. Bertrand, M., Mehta, P., and Mullainathan, S. (2002) Ferreting out Tunnelling: An Application to Indian Business Groups, Quarterly Journal of Economics, 117, 121-148.

2. Brick, I.E., Palmon, O. and Wald, J.K. (2006) CEO Compensation, Director Compensation, and Firm Performance: Evidence of Cronyism? Journal of Corporate Finance, 12, 403- 423.

3. Chang, S.J. (2003) Ownership Structure, Expropriation, and Performance of Group-Affiliated Companies in Korea, Academy of Management Journal, 46(2), 238-253.

4. Chen, C.L., Yen, G., Fu, C.J. and Chang, F.H. (2007) Family Control, Auditor Reputation, and Audit Quality: Empirical Evidence from the TSElisted Firms (1999-2002), Corporate Ownership \& Control, 5(3), 96-110.

5. Chu, W., (2004) Are Group-Affiliated Firms Really More Profitable than Nonaffiliated? Small Business Economics 22, 391-405.

6. Claessens, S., Djankov, S. and Lang, L. H. P. (2002) Disentangling the incentive and entrenchment effects of large shareholding, Journal of Finance, 56(6): 2741-2771.

7. Clement, R. W. (2006), Just How Unethical is American Business? Business Horizon, 49, 313-327.

8. Cordeiro, J., Veliyath, R. and Eramus, E. (2000) An Empirical Investigation of the Determinants of Outside Director Compensation, Corporate Governance: An International Review, 8(3), 268279.

9. Crespí-Cladera, R. and Gispert, C. (2003) Total Board Compensation, Governance and Performance of Spanish Listed Companies, LABOUR, 17(1) 103126.

10. Dewing, I.P. and Russell, P.O. (2004) Regulation of UK Corporate Governance: Lessons from Accounting, Audit and Financial Services, Corporate Governance: An International Review, 12(1), 107-115.

11. DiMaggio, P. J. and Powell W.W. (1983). The Iron Cage Revisited: Institutional Isomorphism and Collective Rationality in Organizational Fields, American Sociological Review, 48, 147-160.

12. Fan, Y. (2002) Questioning Guanxi: Definition, Classification and Implications, International Business Review, 11, 543-561.

13. Felo, A.J. (2001) Ethics Programs, Board Involvement, and Potential Conflicts of Interest in Corporate Governance, Journal of Business Ethics, 32: 205-218.

14. Fliatotchev, I. Lien, Y.C. and Piesse, J. (2005) Corporate Governance, Performance in Publicly Listed, Family-Controlled Firms: Evidence from Taiwan, Asia Pacific Journal of Management, 22, 257-283. 
15. Gaver, J.J. and Gaver, K.M. (1995) Compensation Policy and the Investment Opportunity Set, Financial Management, 24, 19- 32.

16. Gul, F. A. and Leung, S. (2004) Board Leadership, Outside Directors' Expertise and Voluntary Corporate Disclosures, Journal of Accounting and Public Policy, 23, 351-379

17. Hamilton, G. (1998). Culture and Organization in Taiwan's Market Economy. In Robert W. Hefner (ed.) Market Cultures: Society and Morality in the New Asian Capitalisms. Westview, Press, 41-77.

18. Jensen, M. (1993) The Modern Industrial Revolution, Exit and the Failure of Internal Control Systems, Journal of Finance, 48, 831-880.

19. Kim, K., Kitsabunnarat, P. and Nofsinger, J.R. (2004) Ownership and Operating Performance in an Emerging Market: Evidence from Thai IPO Firms, Journal of Corporate Finance, 10(3), 355-381.

20. Kumar, P. and Zattoni, A. (2013) Corporate governance, Board of directors, and Firm Performance, Corporate Governance: An International Review, 21(4), 311-313.

21. La Porta, R., Lopez-de-Silances, F., Shleifer, A. and Vishny, R.W. (1997) Legal Determinants of External Finance, Journal of Finance, 52(3), 11311150.

22. La Porta, R., Lopez-de-Silanes, F. and Shleifer, A. (1999) Corporate Ownership Around the World, Journal of Finance, 54, 471-517.

23. Lee, T.S. and Yeh, Y.H. (2004) Corporate Governance and Financial Distress: Evidence from Taiwan, Corporate Governance: An International Review, 12(3), 378-388.

24. Lehn, K., Netter, J. and Poulsen, A. (1990) Consolidation Corporate Control: Dual Class Recapitalisations versus Leverage Buyout, Journal of Financial Economics, 27, 347-376.

25. Linn, S.C. and Park, D. (2005) Outside Director Compensation Policy and the Investment Opportunity Set, Journal of Corporate Finance, 11(4), 680-715.

26. Luan, C.J. and Tang, M.J. (2007) Where is Independent Director Efficacy? Corporate Governance: An International Review, 15(4), 636643.

27. Luo, X. and Chung, C.N. (2005) Keeping it All in the Family: The role of Particularistic Relationships in Business Group Performance during Institutional Transition, Administrative Science Quarterly, 50, 404-439.

28. McClain, G. (2012) Outside Director Equity Compensation and the Monitoring of Management, Journal of Applied Business Research, 28(6), 13151330.
29. Neter, J., Wasserman, W. and Kutner, M. (1985) Applied Linear Statistical Models ( $2^{\text {nd }}$ ed.). Homewood, IL: Irwin.

30. Peng, M.W. (2004) Outside Directors and Firm Performance During Institutional Transitions, Strategic Management Journal, 25, 453-471.

31. Peng, M.W., Buck, T. and Fliatotchev, I. (2003) Do Outside Directors and New Managers Help Improve Firm Performance? An Exploratory Study in Russian Privatization, Journal of World Business, 38, 348-360.

32. Pye, L.W. (1985). Asia power and politics: the cultural dimensions of authority. Cambridge. Mass.: Harvard University Press.

33. Rhee, M. and Lee, J. (2008) The Signals Outside Directors Send to Foreign Investors: Evidence from Korea, Corporate Governance: An International Review, 16(1), 41-51.

34. Ryan, H.E. and Wiggins III, R.A. (2004) Who is in Whose Pocket? Director Compensation, Board Independence, and Barriers to Effective Monitoring, Journal of Financial Economics, 73, 497-524.

35. Shleifer, A. and Vishny, R. (1997) A Survey of Corporate Governance, Journal of Finance, 52, 737783.

36. Tsai, W.-H., Hung, J.-H., Kuo, Y.-C. and Kuo, L.(2006) CEO tenure in Taiwanese family and nonfamily firms: An agency theory perspective, Family Business Review, 19(1), 11-28.

37. Wu, C.F. (2006) The Study of the Relations among Ethical Considerations, Family Management and Organizational Performance in Corporate Governance, Journal of Business Ethics, 68: 165179.

38. Yeh, Y.H. (2005) Do Controlling Shareholders Enhance Corporate Value? Corporate Governance: An International Review, 13(2), 313-325.

39. Yeh, Y.H., Lee, T.S. and Woidtke, T. (2001) Family Control and Corporate Governance: Evidence from Taiwan, International Review of Finance, 2, 21-48.

40. Yermack, D. (1996). Higher market valuation for firms with a small board of directors. Journal of Financial Economics 40: 185-211.

41. Young, C. and Tsai, L. (2008) The Sensitivity of Compensation to Social Capital: Business Research, 61, 363-374.

42. Zahra, S.A. (2003) International Expansion of U.S. Manufacturing Family Businesses: the Effects of Ownership and Involvement, Journal of Business Venturing, 18, 495-512. 


\title{
РАЗДЕЛ 3 \\ КОРПОРАТИВНОЕ УПРАВЛЕНИЕ В РАЗВИВАЮЩИХСЯ СТРАНАХ
}

\section{SECTION 3}

CORPORATE

GOVERNANCE IN

DEVELOPING COUNTRIES

\section{;}

HIGH VOLUME TRADES AND STOCK PRICE CHANGES IN

BRAZIL

\author{
Andre Carvalhal*, Cesar Martins ${ }^{* *}$, Otavio Figueiredo ${ }^{* *}$
}

\begin{abstract}
This work analyzes the relation between stock price changes and high volume trades in Brazil. Using a unique intra-day database, we evaluate 10 of the most liquid shares from 2001 to 2006. Unlike most international studies, which are based on data from funds or institutional investors, this article breaks new ground by working with publicly available information. Our results indicate a positive and significant relation between stock price changes and high volume trades. In line with existing literature, we show there are both temporary and partially permanent on stock prices after high volume trades. Our study also indicates the existence of asymmetry between purchases and sales.
\end{abstract}

Keywords: Returns, Liquidity, Intra-Day Data

JEL: G12, G17

* Pontifical Catholic University of Rio de Janeiro

* Federal University of Rio de Janeiro

\section{Introduction}

In an efficient market, the value of an asset should reflect the exact present value of the expected cash flows created by this same asset with the information made available to all interested investors. When several small investors have access to the same information, price fluctuations should only occur with the disclosure of new information or with changes in the risk-return profile of the investors.

One can suppose that in a given market there are a large number of small investors, but also some investors that stand out due to their size. In such situation, it is possible to conceive that large investors may experience some difficulty in executing high volume orders since they may not find enough counetrparties for them. These orders may change the balance of prices with immediate and permanent consequences. The immediate effect is due to the instantaneous lack of market liquidity. The permanent impact happens through the tipping of the asset's demand curve, causing a real modification of its actual value.

Although extensively studied and accepted, these effects were very seldom measured for intradaily operations due to the difficulty in obtaining data. With the increasing availability of data in electronic media, some studies have been done for developed countries (Chan and Lakonishok (1995), Chiyachantana, Jain, Jiang and Wood (2004), 
Almgrem, Thum, Hauptmann and Li (2005) and Bikker, Spierdijk and Van der Sluis (2007)).

The purpose of this paper is to analyze the impact of high volume operations over stock prices in Brazil. This paper innovates by working with publicly available information, as opposed to most international publications, which are based on proprietary data provided by funds or institutional investors and made available only to the authors of such papers. Although there are many international studies on the subject, intra-daily impacts of high volume orders have not yet been studied in Brazil. Using a database containing intra-daily data, 10 high liquid stocks are analyzed from 2001 to 2006.

The findings of this paper indicate a positive and statistically relevant relation between the impacts on stock prices and high volume operations. We show that there are temporary and permanent impacts on stock prices following high volume operations, and that these impacts are asymmetric for buys and sells.

The paper is structured as follows: the next section contains an overview of the literature review and Section 3 shows the data and methodology used in this work; Section 4 presents the results and Section 5 discusses the main conclusions of this study.

\section{Literature Review}

In the international literature one can find several studies analyzing, on an intra-daily basis, the impact of high volume operations on stock prices. Most of these works, it must be said, base their research on proprietary data provided by a given investor (investment funds, pension funds or other institutional investors).

Chan and Lakonishok (1995), Chiyachantana, Jain, Jiang and Wood (2004), Almgrem, Thum, Hauptmann and Li (2005) and Bikker, Spierdijk and Van der Sluis (2007) identify a positive relation between the volume of a given operation and its impact on stock prices. They also indicate the existence of an asymmetry in these results when comparing purchase and sale operations.

Even though most studies present similar findings, there is no consensus about the volume necessary for an operation to be considered a high volume one and able to cause some effect on stock prices. The first studies on the subject used as a parameter the proportion between the volume of the operation and the total volume negotiated on the same day. Almgrem, Thum, Hauptmann and Li (2005) have improved this method and use the ratio between the volume of the operation and a portion of the total daily volume negotiated in the same lapse of time in which the operation was executed.

Bikker, Spierdijk and Van der Sluis (2007) use two different and independent variables: the ratio between the volume of a single operation and the total volume of available stocks; and the ratio between the volume of this same operation and the total volume negotiated on the same day. Keim and Madhavan (1997) and Chiyachantana, Jain, Jiang and Wood (2004) show that the impact on stock prices is positively related to the complexity of the high volume operation, which is measured through the number of brokers involved and the number of days necessary for its execution.

Some authors analyze the relation between operation size and impact on stock prices in different countries. Bikker, Spierdijk and Van der Sluis (2007) demonstrate weaker impacts and lower transaction costs in the United States when compared to Europe, Japan and Canada. The authors explain that this difference may be related to the higher liquidity of the U.S. stock market.

Chiyachantana, Jain, Jiang and Wood (2004) study the impact of high volume operations in 39 countries and concude that they are more significant in emerging markets, which usually have worse corporate governance. The authors argue that good governance, a better enforcement of shareholders' rights and the existance of regulations against insider trading reduce the impact of the operations. Such finding corroborates the findings of La Porta et al. (1998), Bekaert and Harvey (2000), Domowitz et al. (2001), Jain (2001) and Bhattacharya and Daouk (2002), which indicate differences between transaction costs in many countries, which they relate to different kinds of governance.

The impact on stock prices is often defined in literature as the sum of temporary and permanent impacts. Kraus and Stoll (1972) define temporary impacts as those caused by a lack of immediate liquidity (price concessions aiming at stimulating buyers or sellers to give liquidity to a stock), inventory effects (temporary effects due to stock inventory imbalance) or imperfect substitution (price concessions to stimulate sellers or buyers to absorb additional shares).

The same authors define the permanent impact as a change in the way the market evaluates a given asset due to the information conveyed by the operation. In other words, a high volume buying operation may be an indication that a given stock is undervalued, leading to a reconsideration of its price by other market participants with a consequent permanent change in its price.

Even though different authors agree on these theoretical concepts, they use slightly different technical definitions. Bikker, Spierdijk and Van der Sluis (2007) define the temporary impact as the return of the stock between the time of the operation and a given moment after the operation; and the permanent impact as the return between a given moment immediately before the operation and a given moment after this same operation.

Other authors use different prices as benchmarks for similar definitions, arguing that, in many cases, prices immediately before or immediately after the 
operation are already (or still) under its influence. This is why it is not unusual to find studies that consider the closing price of the previous day or the opening price of the day of the operation as proxies for the price before the operation, and the closing price of the day of the operation or the opening price of the next day for the purpose of measuring permanent impact.

Chan and Lakonishok (1995) use as a measure of impact the difference between the price truly executed in the operation and the price of the asset at the opening of the first day of the operation. Keim and Madhavan (1997) and Chiyachantana, Jain, Jiang and Wood (2004) also consider the price truly executed during the trade.

To differentiate temporary from permanent impacts one must also measure the prices immediately after the operation and a sufficiently long time afterwards. Almgrem, Thum, Hauptmann and $\mathrm{Li}$ (2005) use the price immediately after the operation to measure temporary effect and the price 30 minutes later to calculate its permanent impact. Other authors use different lapses of time to measure permanent impact, such as 15 or 30 minutes, or even hours.

The analysis of the impact of high volume orders over prices must also consider that operations can be made in blocks. Barclay and Warner (1993), when studying the positioning of informed investors, conclude that when operating with small (up to 500 shares) or medium (500 to 10,000 shares) orders, the buyer (or seller) does not influence the market enough to justify the payment of a premium. For big orders (more than 10,000 shares), on the contrary, the market starts to notice the buying (or selling) operation and realizes that the investor has acces to some information not known to the market. Hence, the authors argue that the operation will be fragmented in several smaller operations in order to go unnoticed through the market, avoiding the payment of a premium.

The first studies on the subject (Kraus and Stoll (1972), Keim and Madhavan (1991) and Chan and Lakonishok (1993)) analyze the impact over prices of isolated trades and disregard the hypothesis of these operations being a part of a bigger "package". Chan and Lakonishok (1995) recognize that to institutional investors even positions considered to be average may represent a significant fraction of the total volume of some stocks. Therefore, it is perfectly natural that this investor breaks this operation in several smaller ones. And even these smaller operations may be broken down in minimal ones through computational algorithms. It would hence be wrong and useless to consider a single operation as the basic trade unit and to study the effects of these small operations on stock prices, since the trade as a whole would in this case be overlooked.

The authors then suggest the creation of a package of operations and observe price behavior around this package instead of around specific operations. Chan and Lakonishok (1995) find that the size of these packages has a significant influence on prices. The question then becomes how to define the package of trades. Chan and Lakonishok (1995) suggest the use of the investor's history to determine what is or is not part of the trade. As a general rule, they say that all the orders of a given investor should be aggregated until he stays out of the market for a considerable lapse of time.

Many authors indicate that there are significant differences on the impact caused by buying or selling operations (Kraus and Stoll (1972), Chan and Lakonishok (1993, 1995), Keim and Madhavan (1997) and Madhavan and Cheng (1997)). In general, purchase operations cause more impact than sales.

Chan and Lakonishok (1993) and Saar (2001) argue that purchase operations convey more information than sale operations. Since institutional investors usually do not carry an investment portfolio that is balanced according to the portfolio of the market, the option of selling does not necessarily convey bad information; the need to sell may be due only to a liquidity issue of this particular investor. On the other hand, the decision of buying a certain stock among all the others available in the market is more likely to convey positive information concerning a specific company.

\section{Data and Methodology}

\subsection{Data}

We use a database containing information on all intradaily transactions occured in BM\&FBovespa for 49 chosen assets from 2001 to 2006. From these 49 assets, the 10 with highest liquidity during this period are selected, since approximately $60 \%$ of the transactions and $80 \%$ of the volume operated are concentrated in the 10 most liquid companies.

The 10 companies analyzed are: Bradesco (bank), Braskem (petrochemical), Cemig (utilities), CSN (steel), Eletrobras (utilities), Gerdau (steel), Petrobras (oil and gas), Telemar (telecomunication), Usiminas (steel) and Vale (mining). The assets are selected in a way that most significant and competitive sectors in Brazil are represented, containing the most liquid firms for each category. The database contains the following information: date and time of the operation (on a second per second time scale), operation volume, trade price and the identification of the selling and buying brokers involved.

As previously mentioned, most of the previous studies were done "from the inside", meaning that they were done by researchers on the base of data supplied by investment funds or brokers. Thus, researchers knew beforehand when trades took place, their direction and whose intiative they were. In our study we are not in possession of the identity of the 
buyer or seller. Therefore, we make an approximation by using the broker as the buying or selling entity.

We know that in doing so we include a "noise" in a single operation, since all orders launched through a given broker, even if coming from different investors, will be considered as parts of a single package. However, since our analysis focuses on very high volume operations, way beyond the normal behavior of any broker for a given period of time, this noise should be small when compared to the size of the operations considered.

Another problem that arises is the possibility of a single investor spreading its orders through different brokers. Chiyachantana, Jain, Jiang and Wood (2004) study 39 countries (among them Brazil) and demonstrate that in average investors use between 1.10 and 1.31 brokers. They point out differences between trades executed in a single day (1.05 broker per investor) and in multiple days (2.02 brokers per investor). Since in the present work we analyze only orders executed in a single day, the supposition of the use of 1 broker per investor for the execution of the orders seems reasonable.

\subsection{Methodology}

Our methodology is based on Chriss and Almgrem (2003) and Almgrem, Thum, Hauptmann and $\mathrm{Li}$ (2005). It must be highlighted, however, that the present work differs from those done so far, since instead of using proprietary information we work with information that is publicly available. By doing so we add yet another difficulty to it, which is the identification of a high volume trade.

As seen in the previous section, there is no consensus around the value to be considered in order to qualify an operation as high volume. Almgrem, Thum, Hauptmann and Li (2005) find an average (median) volume of $1.51 \%(0.62 \%)$ of the total volume negotiated daily, and use as minimum cutoff values for high volume operations $0.25 \%$ of the total daily volume and at least 1,000 shares traded. Chan and Lakonishok (1995) find averages (medians) of $66 \%(11 \%)$ for buys and $61 \%(7 \%)$ for sales. Bikker, Spierdijk and Van der Sluis (2007) find an average volume for the operations of $4.3 \%$ of the total daily volume for buys and $3.4 \%$ for sales.

Hence, there is no single standard to define high volume operations. However, the use of some sort of cutoff value is necessary. Since we cannot preciselly establish from which value operations become relevant, we adopt several cutoff values: $10 \%, 20 \%$, $30 \%, 40 \%$ and $50 \%$. We use 2 proxies to measure the volume of the operation: the ratio between the volume of the operation and the total volume negotiated during the same period; and the ratio between the volume of the operation and the total volume negotiated during that day.

The interval considered for the aggregation of the operations in packages is also an important factor on which there is no consensus in the literature. Bikker, Spierdijk and Van der Sluis (2007) show that operation packages usually last between $0.22 \mathrm{~h}$ and 6.75h. Almgrem, Thum, Hauptmann and Li (2005) find average time for operation packages of $2.73 \mathrm{~h}$. In the present work, since our database is intra-daily, we consider different intervals ( 1 minute, 5 minutes, 10 minutes, 20 minutes and 30 minutes) to include an operation as part of a block.

Another difference between our study and most previous researches is that besides the immediate impact, we also measure the permanent impact of operations. In this regard, we have to estimate a lapse of time subsequent to the operation after which it no longer causes liquidity changes. Almgrem, Thum, Hauptmann and Li (2005) used a lapse of 30 minutes to measure the permanent impact, and we adopt this interval in this paper as well.

Most studies calculate the impact on stock returns adjusted for the market return. None of them, however, multiplies the market return by the stock beta, meaning that the authors simply calculate the return of the asset and subtract the return of the market. We use a simple modification of the model by the inclusion of the stock beta, as per equation 1 below:

\section{Stock Impact $=$ Stock Return - Beta $x$ Market Return}

Barclay and Warner (1993), Chan and Lakonishok (1993), Chan and Lakonishok (1995), Chiyachantana, Jain, Jiang and Wood (2004) and Bikker, Spierdijk and Van der Sluis (2007) use only linear regressions to relate operation volume and price impact. Chriss and Almgrem (2003) and Almgrem, Thum, Hauptmann and Li (2005) alert, however, to the possibility of this relation being polynomial or exponential. The authors admit, nevertheless, that a very large amount of data would be necessary for a conclusion about the form of the equation to be reached. They assume, hence, that the polynomial form is the most likely one and use regressions to determine the parameters and coefficients. In our work, we test three functional formats: linear, polynomial and exponential.

Before presenting the results, we make an overview of the different proceedings followed. The first step is aggregating the operations according to their timing and to the broker or brokers involved. With the data aggregated per broker, we search for relevant operations by using different cutoff values $(10 \%, 20 \%, 30 \%, 40 \%$ e $50 \%)$ according to the total volume negotiated in the period of the operation and to the volume negotiated during the day. This filter is not enough, since we may have high volume operations that are "confronted" by other high volume operations at the other end. Hence, besides being relevant, the operation has to be big enough to overcome this contrary pressure. In other words, we 
select, for instance, buys higher than $10 \%$ as long as at the other end there is no sale higher than $10 \%$. Thus, we select only operations that we could clearly identify as a buy or a sale due to the dispersion of the operations at the other end through several brokers. Finally, we calculate the dependent variables: immediate impact (stock at the end of the operation minus the market return adjusted by beta) and permanent impact (stock return 30 minutes after the end of the operation minus the market return adjusted by beta).

We use two independent variables: volume of the operation/total volume negotiated during the same period, and volume of the operation/total volume negotiated during the same day. It is worth highlighting that the main explanatory variable is not merely the total volume of the operation, but its net volume. For example, having a buy of $80 \%$ of the volume and a sale of $40 \%$ of the volume, one may use as independent variable either the total negotiated volume $(80 \%)$ or the net result of the operation $(80 \%$ $-40 \%=40 \%)$. We test both variables and the results are significantly stronger when the net volume is adopted instead of the total volume.

We estimate three equations to relate the dependent and independent variables:

$$
\begin{aligned}
& \text { Impact }=\alpha_{1}+\alpha_{2} \times \text { Volume } \\
& \text { Impact }=\alpha_{1}+e^{\alpha_{2} \times \text { Volume }} \\
& \text { Impact }=\alpha_{1}+\alpha_{2} \times \text { Volume } \alpha_{3}^{\alpha_{3}}
\end{aligned}
$$

where Impact is the immediate and permanent stock return minus the market return adjusted by beta), Volume is the net volume of the operation (divided by the total volume negotiated during the same period and during the same day), $\alpha_{1}, \alpha_{2}$ and $\alpha_{3}$ are estimated parameters. The coefficient that we are most interested in is $\alpha_{2}$, which shows the relation between stock impact and operation volume.

\section{Results}

Six dimensions are analyzed: the type of impact (immediate and permanent), the cutoff value used in the selection of the operations, the time scale considered for aggregating the operations, the type of operation (buy or sell), the volume to be considered for the calculation of the net result (volume negotiated during the period of the operation or during the day) and the equation specification (linear, exponential, polynomial).

Due to the many dimensions analyzed, 36,000 regressions are estimated, being 3,600 per asset and 720 for each interval of each asset. From this total, $49 \%$ show a significant relation at the 5\% level between impact on stock prices and operation volume. Table 1 shows the percentage of significant coefficients that relate stock impact and operation volume ( $\alpha_{2}$ in Eqs II to IV). Dne can notice that there are fewer significant values for bigger intervals. This seems consistent with the IIfypothesys according to which most of the impact is immediate.

Table 1. Percentage of Significant Coefficients that Relate Stock Impact and Operation Volume

This table shows the percentage of significant coefficients that relate stock impact and operation volume ( $\alpha_{2}$ in Eqs II to IV). Linear, exponential and polynomial regressions are estimated and the dependent variable is the impact on stock prices at the

\begin{tabular}{|c|c|c|c|c|c|c|c|c|c|c|c|}
\hline $\begin{array}{l}\text { Stock / } \\
\text { Interval }\end{array}$ & Bradesco & Braskem & Cemig & $\mathrm{CSN}$ & Eletrobras & Gerdau & Petrobras & Telemar & Usiminas & Vale & Total \\
\hline $1 \mathrm{~m}$ & $63 \%$ & $85 \%$ & $49 \%$ & $73 \%$ & $71 \%$ & $63 \%$ & $65 \%$ & $56 \%$ & $81 \%$ & $82 \%$ & $69 \%$ \\
\hline $5 \mathrm{~m}$ & $57 \%$ & $67 \%$ & $39 \%$ & $57 \%$ & $58 \%$ & $52 \%$ & $56 \%$ & $63 \%$ & $64 \%$ & $47 \%$ & $56 \%$ \\
\hline $10 \mathrm{~m}$ & $45 \%$ & $65 \%$ & $38 \%$ & $52 \%$ & $59 \%$ & $50 \%$ & $49 \%$ & $46 \%$ & $52 \%$ & $37 \%$ & $49 \%$ \\
\hline $20 \mathrm{~m}$ & $25 \%$ & $45 \%$ & $32 \%$ & $40 \%$ & $53 \%$ & $41 \%$ & $37 \%$ & $49 \%$ & $34 \%$ & $27 \%$ & $38 \%$ \\
\hline $30 \mathrm{~m}$ & $31 \%$ & $27 \%$ & $26 \%$ & $39 \%$ & $43 \%$ & $41 \%$ & $28 \%$ & $29 \%$ & $28 \%$ & $24 \%$ & $32 \%$ \\
\hline Total & $44 \%$ & $58 \%$ & $37 \%$ & $52 \%$ & $57 \%$ & $50 \%$ & $47 \%$ & $48 \%$ & $52 \%$ & $43 \%$ & $49 \%$ \\
\hline
\end{tabular}
end of the operation or 30 minutes after the end of the operation. The models are estimated using different aggregation intervals $(1,5,10,20$ and 30 minutes), and includes purchase and sale operations.

It is worth pointing out that the percentage of significant coefficients presented in Table 1 refers to all the estimated regressions and dimensions. Given that the number of analysis is enormous and due to lack of space we opt for presenting only the most relevant results here. However, all the results are available upon request.

We start modeling immediate stock impact through linear regressions. We use the cutoffs of $10 \%$, $20 \%, 30 \%, 40 \%$ and $50 \%$ to define high volume operations. These cutoffs are applied to both the volume negotiated during the period of the operation and to the volume negotiated during the day. Table 2 shows the coefficients that relate stock impact and operation volume ( $\alpha_{2}$ in Eqs II to IV).

Most methods present a large number of significant coefficients, indicating that there is a relation between volume of the operation and impact on stock prices. The coefficients and their significance vary a lot according to the cutoff level, aggregation interval and company. However, we can note that the results are more significant for shorter intervals, 
which is in fact expected to happen. Therefore, for short intervals we are able to observe an almost immediate effect caused by the operation volume on stock prices. The $20 \%$ cutoff presents the largest number of significant coefficients.

Table 2. Impact on Stock Prices and Operation Volume for Different Cutoff Values

This table shows the coefficients that relate stock impact and operation volume ( $\alpha_{2}$ in Eqs II to IV). Linear regressions are estimated and the dependent variable is the impact on stock prices at the end of the operation. The models are estimated using different aggregation intervals $(1,5,10,20$ and 30 minutes). Panels A to E show the results for the following cutoff values, respectively: $10 \%, 20 \%, 30 \%, 40 \%$ and $50 \%$. These cutoffs are applied to both the volume negotiated during the period of the operation and to the volume negotiated during the day. ***, ** and * indicate statistical significance at $1 \%, 5 \%$ and $10 \%$, respectively.

\section{Panel A: $10 \%$ Cutoff}

\begin{tabular}{|c|c|c|c|c|c|c|c|c|c|c|}
\hline $\begin{array}{l}\text { Stock / } \\
\text { Interval }\end{array}$ & Bradesco & Braskem & Cemig & CSN & Eletrobras & Gerdau & Petrobras & Telemar & Usiminas & Vale \\
\hline $1 \mathrm{~m}$ & $4.23 * *$ & $7.37 * * *$ & $4.05 *$ & $4.85 * * *$ & $3.77 * * *$ & $2.84 * * *$ & $1.68 * * *$ & $1.75^{* * *}$ & $5.78 * * *$ & $2.25 * * *$ \\
\hline $5 \mathrm{~m}$ & 5.29 & 2.67 & 5.69 & $4.94 * *$ & $5.38 * * *$ & 2.00 & $3.21 * * *$ & $2.36 * * *$ & $5.77 * * *$ & $2.52 * *$ \\
\hline $10 \mathrm{~m}$ & 12.65 & 2.92 & 3.67 & 0.53 & $7.32 * * *$ & $6.56^{* *}$ & 2.63 & $3.66^{* *}$ & $8.52 *$ & 2.29 \\
\hline $20 \mathrm{~m}$ & 4.37 & 0.86 & 13.23 & $10.68 *$ & $8.79 * *$ & $14.62 * * *$ & 2.27 & 3.54 & 5.51 & -1.43 \\
\hline $30 \mathrm{~m}$ & 15.70 & $17.00 *$ & 6.61 & 3.78 & $10.48 * *$ & 7.09 & 0.96 & -5.23 & 6.33 & -1.18 \\
\hline \multicolumn{11}{|c|}{ Panel B: $20 \%$ Cutoff } \\
\hline $\begin{array}{l}\text { Stock / } \\
\text { Interval }\end{array}$ & Bradesco & Braskem & Cemig & CSN & Eletrobras & Gerdau & Petrobras & Telemar & Usiminas & Vale \\
\hline $1 \mathrm{~m}$ & $1.44 * *$ & $4.09 * * *$ & $2.53 * * *$ & $1.80 * * *$ & $1.89 * * *$ & $2.15 * * *$ & $0.78 * * *$ & $0.57 * * *$ & $2.94 * * *$ & $1.34 * * *$ \\
\hline $5 \mathrm{~m}$ & $2.29 * * *$ & $1.93 * *$ & $2.74 * * *$ & $3.18 * * *$ & $2.08 * * *$ & $3.05 * * *$ & $0.90 * * *$ & $0.82 * * *$ & $1.66 * *$ & 0.21 \\
\hline $10 \mathrm{~m}$ & $1.90 * *$ & $2.90 * * *$ & $2.13 * *$ & $1.70 *$ & $2.94 * * *$ & $2.69 * * *$ & $0.72 * *$ & $1.58 * * *$ & 1.08 & $1.76 * * *$ \\
\hline $20 \mathrm{~m}$ & $2.02 * * *$ & $4.16^{* * *}$ & 2.12 & $2.30 * *$ & 0.84 & $2.06 * *$ & $1.66^{* *}$ & $1.84 * *$ & $2.09 * *$ & 0.37 \\
\hline $30 \mathrm{~m}$ & $3.78 * * *$ & 3.36 & 1.92 & 1.80 & $2.77 * *$ & 3.09 & 0.93 & 1.67 & 1.85 & 0.40 \\
\hline \multicolumn{11}{|c|}{ Panel C: $30 \%$ Cutoff } \\
\hline $\begin{array}{l}\text { Stock / } \\
\text { Interval }\end{array}$ & Bradesco & Braskem & Cemig & $\mathrm{CSN}$ & Eletrobras & Gerdau & Petrobras & Telemar & Usiminas & Vale \\
\hline $1 \mathrm{~m}$ & $1.33 * * *$ & $2.31 * * *$ & $1.48 * * *$ & $1.64 * * *$ & $1.57 * * *$ & $1.26 * * *$ & $0.51 * * *$ & $0.40 * * *$ & $1.33 * * *$ & $0.68 *$ \\
\hline $5 \mathrm{~m}$ & 1.00 & $0.99 * *$ & $1.10^{* *}$ & $1.69 * * *$ & $1.03 * * *$ & $1.24 * * *$ & $0.61 * * *$ & $0.56^{* * *}$ & $1.40 * * *$ & $0.71 *$ \\
\hline $10 \mathrm{~m}$ & 2.13 & 1.61 & $1.58 * *$ & $1.49 * *$ & 0.85 & $1.55^{* * *}$ & $0.69 * *$ & $0.57 * *$ & $1.51 * * *$ & 0.14 \\
\hline $20 \mathrm{~m}$ & 2.51 & 1.71 & 0.03 & 1.48 & $1.83 * *$ & $2.07 * *$ & 0.84 & $0.93 *$ & 1.36 & 0.09 \\
\hline $30 \mathrm{~m}$ & -0.90 & 1.64 & -0.35 & 0.80 & $2.47 * *$ & 1.83 & 0.95 & 0.13 & 1.25 & 0.61 \\
\hline \multicolumn{11}{|c|}{ Panel D: $40 \%$ Cutoff } \\
\hline $\begin{array}{l}\text { Stock / } \\
\text { Interval }\end{array}$ & Bradesco & Braskem & Cemig & $\mathrm{CSN}$ & Eletrobras & Gerdau & Petrobras & Telemar & Usiminas & Vale \\
\hline $1 \mathrm{~m}$ & $0.69 * * *$ & $0.98 * * *$ & $0.80 * * *$ & $0.91 * * *$ & $0.85 * * *$ & $0.72 * * *$ & $0.35 * * *$ & $0.32 * * *$ & $0.79 * * *$ & $0.44 * * *$ \\
\hline $5 \mathrm{~m}$ & 0.19 & $1.31 * * *$ & $0.83 * * *$ & $2.02 * * *$ & $0.68 * * *$ & $0.79 * * *$ & $0.50 * * *$ & $0.69 * * *$ & $1.28 * * *$ & 0.28 \\
\hline $10 \mathrm{~m}$ & -0.54 & $1.37 * * *$ & 0.68 & $1.54 * * *$ & $1.04 * * *$ & $1.40 * * *$ & $0.49 *$ & $0.59 * *$ & $1.60 * * *$ & 0.30 \\
\hline $20 \mathrm{~m}$ & -1.29 & 1.18 & 0.79 & 0.82 & $1.24 *$ & 1.40 & $1.22 * *$ & $1.20 * *$ & 0.59 & 0.87 \\
\hline $30 \mathrm{~m}$ & -2.73 & 0.60 & 0.10 & 2.11 & 1.30 & $2.82 * *$ & 0.08 & 1.30 & 0.95 & -0.24 \\
\hline \multicolumn{11}{|c|}{ Panel E: 50\% Cutoff } \\
\hline $\begin{array}{l}\text { Stock / } \\
\text { Interval }\end{array}$ & Bradesco & Braskem & Cemig & CSN & Eletrobras & Gerdau & Petrobras & Telemar & Usiminas & Vale \\
\hline $1 \mathrm{~m}$ & $0.48 * *$ & $1.12 * * *$ & $0.65 * * *$ & $0.72 * * *$ & $0.75 * * *$ & $0.51 * * *$ & $0.31 * * *$ & $0.47 * * *$ & $0.66^{* * *}$ & $0.46^{* * * *}$ \\
\hline $5 \mathrm{~m}$ & 0.63 & $0.80 * * *$ & $0.77 * * *$ & $1.26 * * *$ & $0.41 *$ & 0.36 & $0.38 * * *$ & $0.65^{* * *}$ & $0.77 * * *$ & $(0.03)$ \\
\hline $10 \mathrm{~m}$ & 0.51 & $1.21 * *$ & 0.32 & 0.59 & $0.91 * *$ & 0.69 & $0.59 * *$ & 0.16 & $1.32 * * *$ & 0.19 \\
\hline $20 \mathrm{~m}$ & 4.59 & 1.39 & $1.34 *$ & 1.46 & $1.53 * *$ & 0.55 & -0.23 & -0.32 & 1.38 & -0.47 \\
\hline $30 \mathrm{~m}$ & -4.96 & 0.64 & 1.41 & -0.11 & 0.63 & 1.33 & -1.11 & $2.48 * *$ & 2.12 & 0.43 \\
\hline
\end{tabular}

As seen in Section 2, some authors use as independent variable the percentage of total volume during the lapse of time in which the operation is executed, while others use the percentage in relation to the volume negotiated during the day. Table 3 shows the results for both alternatives using a cutoff of $20 \%$ to define high volume operations. 
Table 3. Impact on Stock Prices and Different Measures of Operation Volume

This table shows the coefficients that relate stock impact and operation volume ( $\alpha_{2}$ in Eqs II to IV). Linear regressions are estimated and the dependent variable is the impact on stock prices at the end of the operation. The models are estimated using different aggregation intervals (1, 5, 10, 20 and 30 minutes) and a cutoff value of 20\%. Panels A and B show the results for different measures of operation volume: percentage of the volume negotiated during the day and percentage of the volume negotiated during the lapse of time in which the operation is executed. $* * * * *$ and $*$ indicate statistical significance at $1 \%$, $5 \%$ and $10 \%$, respectively.

Panel A: Percentage of the Volume Negotiated During the Day

\begin{tabular}{lllllllllll}
\hline $\begin{array}{l}\text { Stock / } \\
\text { Interval }\end{array}$ & Bradesco & Braskem & Cemig & CSN & Eletrobras & Gerdau & Petrobras & Telemar & Usiminas & Vale \\
\hline $1 \mathrm{~m}$ & $1.55 * * *$ & $4.53 * * *$ & $3.43 * * *$ & $2.17 * * *$ & $2.48 * * *$ & $2.58 * * *$ & $0.92 * * *$ & $0.93 * * *$ & $3.04 * * *$ & $1.72 * * *$ \\
$5 \mathrm{~m}$ & $2.48 * * *$ & $4.20 * * *$ & $3.10^{* * *}$ & $2.94 * * *$ & $3.12 * * *$ & $2.58 * * *$ & $1.10 * * *$ & $0.92 * * *$ & $3.04 * * *$ & $1.54 * * *$ \\
$10 \mathrm{~m}$ & $2.55 * * *$ & $5.10 * * *$ & $3.81 * * *$ & $2.65 * * *$ & $3.62 * * *$ & $2.85 * * *$ & $0.86 * * *$ & $1.31 * * *$ & $2.86 * * *$ & $2.40 * * *$ \\
$20 \mathrm{~m}$ & $2.88 * * *$ & $5.99 * * *$ & $4.62 * * *$ & $3.06 * * *$ & $3.78 * * *$ & $4.28 * * *$ & $2.08 * * *$ & $1.94 * * *$ & $2.87 * * *$ & $3.17 * * *$ \\
$30 \mathrm{~m}$ & $4.63 * * *$ & $6.43 * * *$ & $4.49 * * *$ & $3.00 * * *$ & $3.76 * * *$ & $5.04 * * *$ & $1.32 * * *$ & $1.63 * * *$ & $4.53 * * *$ & $3.23 * * *$ \\
\hline
\end{tabular}

Panel B: Percentage of the Volume Negotiated During the Lapse of Time in which the Operation is Executed

\begin{tabular}{llllllllll}
\hline $\begin{array}{l}\text { Stock / } \\
\text { Interval }\end{array}$ & Bradesco & Braskem & Cemig CSN & Eletrobras & Gerdau & Petrobras & Telemar & Usiminas Vale \\
\hline $1 \mathrm{~m}$ & $27.98 * * *$ & $41.82 * * *$ & $43.93 * * * 50.61 * * * 39.47 * * *$ & $52.01 * * *$ & $24.90^{* * *}$ & $19.89 * * *$ & $76.21 * * *$ & $49.03 * * *$ \\
$5 \mathrm{~m}$ & $16.17 * * *$ & $45.48 * * *$ & $33.74 * * * 36.41 * * * 46.02 * * *$ & $45.60 * * *$ & $28.28 * * *$ & $13.15 * * *$ & $70.69 * * *$ & $30.75 * * *$ \\
$10 \mathrm{~m}$ & $10.03 * *$ & $43.60 * * *$ & $36.29 * * * 39.43 * * * 34.75 * * *$ & $42.71 * * *$ & $25.69 * * *$ & $12.52 * * *$ & $64.40 * * *$ & $26.45 * * *$ \\
$20 \mathrm{~m}$ & $6.87 * *$ & $36.14 * * *$ & $33.67 * * * 34.47 * * * 34.95 * * *$ & $41.25 * * *$ & $19.04 * * *$ & $22.54 * * *$ & $57.23 * * *$ & $13.82 * * *$ \\
$30 \mathrm{~m}$ & $4.21 * *$ & $42.86 * * *$ & $39.58 * * * 24.08 * * * 37.05 * * *$ & $51.92 * * * 30.54 * * *$ & $10.45 * * *$ & $48.52 * * *$ & $21.12 * * *$ \\
\hline
\end{tabular}

All coefficients that relate stock impact and operation volume ( $\alpha_{2}$ in Eqs II to IV) are significant at $1 \%$ or $5 \%$ levels. Therefore we can conclude that both alternatives to measure operation volume have a significant relationship with stock impact. The difference between both independent variables is minimal, indicating a slightly superior performance for the percentage volume negotiated during the day, which presents all coefficients significant at $1 \%$. When the cutoff is modified (not only 20\%), the percentage of the daily volume continue to present more significant coefficients than the percentage of the volume during the lapse of time in which the operation took place.

Table 4 brings a comparison between linear, exponential and polynomial models with a cutoff of $20 \%$ and using the percentage of the daily volume as independent variable. All coefficients that relate stock impact and operation volume ( $\alpha_{2}$ in Eqs II to IV) are significant at $1 \%$. As can be seen, the results are similar for all models. When the analysis is repeated varying other dimensions, the linear model presents a slightly superior performance, with more significant coefficients than the other models.

Table 4. Linear, Exponential and Polynomial Relations between the Impact on Stock Prices and Operation Volume

This table shows the coefficients that relate stock impact and operation volume ( $\alpha_{2}$ in Eqs II to IV). Linear, exponential and polynomial regressions are estimated and the dependent variable is the impact on stock prices at the end of the operation. The models are estimated using different aggregation intervals (1, 5, 10, 20 and 30 minutes), a cutoff value of 20\% and operation volume is measured by the percentage in relation to the total volume negotiated during the day. Panels $\mathrm{A}, \mathrm{B}$ and $\mathrm{C}$ show the results of the linear, exponential and polynomial models, respectively. $* * * * *$ and $*$ indicate statistical significance at $1 \%$, $5 \%$ and $10 \%$, respectively.

\section{Panel A: Linear Model}

\begin{tabular}{|c|c|c|c|c|c|c|c|c|c|c|}
\hline $\begin{array}{l}\text { Stock / } \\
\text { Interval }\end{array}$ & Bradesco & Braskem & Cemig & $\mathrm{CSN}$ & Eletrobras & Gerdau & Petrobras & Telemar & Usiminas & Vale \\
\hline $1 \mathrm{~m}$ & $1.55 * * *$ & $4.53 * * *$ & $3.43 * * *$ & $2.17 * * *$ & $2.48 * * *$ & $2.58 * * *$ & $0.92 * * *$ & $0.93 * * *$ & $3.04 * * *$ & $1.72 * * *$ \\
\hline $5 \mathrm{~m}$ & $2.48 * * *$ & $4.20 * * *$ & $3.10 * * *$ & $2.94 * * *$ & $3.12 * * *$ & $2.58 * * *$ & $1.10 * * *$ & $0.92 * * *$ & $3.04 * * *$ & $1.54 * * *$ \\
\hline $10 \mathrm{~m}$ & $2.55 * * *$ & $5.10 * * *$ & $3.81 * * *$ & $2.65 * * *$ & $3.62 * * *$ & $2.85 * * *$ & $0.86 * * *$ & $1.31 * * *$ & $2.86 * * *$ & $2.40 * * *$ \\
\hline $20 \mathrm{~m}$ & $2.88 * * *$ & $5.99 * * *$ & $4.62 * * *$ & $3.06 * * *$ & $3.78 * * *$ & $4.28 * * *$ & $2.08 * * *$ & $1.94 * * *$ & $2.87 * * *$ & $3.17 * * *$ \\
\hline $30 \mathrm{~m}$ & $4.63 * * *$ & $6.43 * * *$ & $4.49 * * *$ & $3.00 * * *$ & $3.76 * * *$ & $5.04 * * *$ & $1.32 * * *$ & $1.63 * * *$ & $4.53 * * *$ & $3.23 * * *$ \\
\hline
\end{tabular}


Panel B: Exponential Model

\begin{tabular}{|c|c|c|c|c|c|c|c|c|c|c|}
\hline $\begin{array}{l}\text { Stock / } \\
\text { Interval }\end{array}$ & Bradesco & Braskem & Cemig & $\mathrm{CSN}$ & Eletrobras & Gerdau & Petrobras & Telemar & Usiminas & Vale \\
\hline $1 \mathrm{~m}$ & $1.41 * * *$ & $0.63 * * *$ & $1.33 * * *$ & $1.77 * * *$ & $0.98 * * *$ & $1.40 * * *$ & $0.46 * * *$ & $2.76 * * *$ & $0.28 * * *$ & $0.53 * * *$ \\
\hline $5 \mathrm{~m}$ & $1.76 * * *$ & $0.98 * * *$ & $7.62 * * *$ & $5.06 * * *$ & $0.96 * * *$ & $0.96 * * *$ & $1.77 * * *$ & $7.01 * * *$ & $1.46 * * *$ & $2.93 * * *$ \\
\hline $10 \mathrm{~m}$ & $1.79 * * *$ & $1.24 * * *$ & $3.54 * * *$ & $1.66^{* * *} *$ & $3.62 * * *$ & $2.75 * * *$ & $4.49 * * *$ & $2.41 * * *$ & $2.81 * * *$ & $2.13 * * *$ \\
\hline $20 \mathrm{~m}$ & $7.99 * * *$ & $5.21 * * *$ & $13.62 * * *$ & $4.60 * * *$ & $6.85^{* * *}$ & $4.77 * * *$ & $1.26 * * *$ & $2.84 * * *$ & $5.13 * * *$ & $7.50 * * *$ \\
\hline $30 \mathrm{~m}$ & $1.94 * * *$ & $2.86^{* * * *}$ & $1.94 * * *$ & $6.20 * * *$ & $0.49 * * *$ & $3.08 * * *$ & $3.62 * * *$ & $5.53 * * *$ & $3.12 * * *$ & $2.66 * * *$ \\
\hline \multicolumn{11}{|c|}{ Panel C: Polynomial Model } \\
\hline $\begin{array}{l}\text { Stock / } \\
\text { Interval } \\
\end{array}$ & Bradesco & Braskem & Cemig & $\mathrm{CSN}$ & Eletrobras & Gerdau & Petrobras & Telemar & Usiminas & Vale \\
\hline $1 \mathrm{~m}$ & $1.47 * * *$ & $1.44 * * *$ & $1.96 * * *$ & $1.33 * * *$ & $1.33 * * *$ & $1.46 * * *$ & $0.76 * * *$ & $1.65 * * *$ & $0.64 * * *$ & $0.73 * * *$ \\
\hline $5 \mathrm{~m}$ & $2.77 * * *$ & $1.41 * * *$ & $3.81 * * *$ & $2.83 * * *$ & $1.29 * * *$ & $1.10 * * *$ & $1.15 * * *$ & $2.84 * * *$ & $1.11 * * *$ & $1.74 * * *$ \\
\hline $10 \mathrm{~m}$ & $7.43 * * *$ & $1.88 * * *$ & $3.07 * * *$ & $1.64 * * *$ & $2.78 * * *$ & $1.95 * * *$ & $1.52 * * *$ & $2.29 * * *$ & $1.60 * * *$ & $1.87 * * *$ \\
\hline $20 \mathrm{~m}$ & $8.30 * * *$ & $4.09 * * *$ & $5.81 * * *$ & $2.81 * * *$ & $3.67 * * *$ & $3.45^{* * *}$ & $2.06 * * *$ & $2.04 * * *$ & $1.98 * * *$ & $5.71 * * *$ \\
\hline $30 \mathrm{~m}$ & $43.40 * * *$ & $3.00 * * *$ & $2.51 * * *$ & $4.32 * * *$ & $1.27 * * *$ & $2.59 * * *$ & $1.62 * * *$ & $4.08 * * *$ & $2.40 * * *$ & $3.03 * * *$ \\
\hline
\end{tabular}

We perform two additional analyses: buys vs. sales and impact on stock prices 30 minutes after the end of the trade. First we compare the results for buy and for sale operations to check if there is asymmetry between them. Table 5 presents the results for the linear models with a $20 \%$ cutoff and using the percentage of the daily volume as independent variable.

Table 5. Impact on Stock Prices and Operation Volume for Buying and Selling Orders

This table shows the coefficients that relate stock impact and operation volume ( $\alpha_{2}$ in Eqs II to IV). Linear regressions are estimated and the dependent variable is the impact on stock prices at the end of the operation. The models are estimated using different aggregation intervals (1, 5, 10, 20 and 30 minutes), a cutoff value of $20 \%$ and operation volume is measured by the percentage in relation to the total volume negotiated during the day. Panels A and B show the results of the model for purchase and sale operations, respectively.

$* * *, * *$ and $*$ indicate statistical significance at $1 \%, 5 \%$ and $10 \%$, respectively.

\begin{tabular}{|c|c|c|c|c|c|c|c|c|c|c|}
\hline \multicolumn{11}{|c|}{ Panel A: Purchase } \\
\hline $\begin{array}{l}\text { Stock / } \\
\text { Interval } \\
\end{array}$ & Bradesco & Braskem & Cemig CSN & Eletrobras & Gerdau & Petrobras & Telemar & Usiminas & Vale & Average \\
\hline $1 \mathrm{~m}$ & $2.01 * * *$ & $6.08 * * *$ & $4.39 * * * 1.76 * * *$ & $* 2.09 * * *$ & $2.10 * * *$ & $0.64 * * *$ & $1.21 * * *$ & $3.67 * * *$ & $2.35 * * *$ & $2.63 * * *$ \\
\hline $5 \mathrm{~m}$ & $3.26 * * *$ & $5.25 * * *$ & $3.91 * * * 3.13 * * *$ & $* 3.32 * * *$ & $2.52 * * *$ & $0.96^{* * *}$ & $0.70 * * *$ & $4.09 * * *$ & $1.73 * * *$ & $2.89 * * *$ \\
\hline $10 \mathrm{~m}$ & $3.41 * * *$ & $6.38 * * *$ & $4.72 * * * 2.70 * * *$ & $* 4.32 * * *$ & $3.17 * * *$ & $0.68 * * *$ & $1.63 * * *$ & $3.01 * * *$ & $3.31 * * *$ & $3.33 * * *$ \\
\hline $20 \mathrm{~m}$ & $4.15^{* * *}$ & $8.13 * * *$ & $6.89 * * * 2.37 * * *$ & $* 3.62 * * *$ & $6.77 * * *$ & $2.68 * * *$ & $2.06 * * *$ & $1.43 * * *$ & $4.66 * * *$ & $4.27 * * *$ \\
\hline $30 \mathrm{~m}$ & $6.85 * * *$ & $10.17 * * *$ & $6.49 * * * 2.57 * * *$ & $* 3.27 * * *$ & $6.85 * * *$ & $0.73 * * *$ & $1.07 * * *$ & $4.87 * * *$ & $3.71 * * *$ & $4.66 * * *$ \\
\hline \multicolumn{11}{|c|}{ Panel B: Sale } \\
\hline $\begin{array}{l}\text { Stock / } \\
\text { Interval } \\
\end{array}$ & Bradesco & Braskem & Cemig CSN & Eletrobras & Gerdau & Petrobras & Telemar & Usiminas & Vale & Average \\
\hline $1 \mathrm{~m}$ & $1.07 * * *$ & $2.92 * * *$ & $2.43 * * * 2.60 * * *$ & $2.89 * * *$ & $3.08 * * *$ & $1.21 * * *$ & $0.64 * * *$ & $2.38 * * *$ & $1.06 * * *$ & $2.09 * * *$ \\
\hline $5 \mathrm{~m}$ & $1.67 * * *$ & $3.11 * * *$ & $2.26 * * * 2.74 * * *$ & $* 2.91 * * *$ & $2.64 * * *$ & $1.25 * * *$ & $1.15 * * *$ & $1.95 * * *$ & $1.34 * * *$ & $2.10 * * *$ \\
\hline $10 \mathrm{~m}$ & $1.65 * * *$ & $3.77 * * *$ & $2.86 * * * 2.60 * * *$ & $* 2.89 * * *$ & $2.52 * * *$ & $1.05 * * *$ & $0.98 * * *$ & $2.70 * * *$ & $1.45 * * *$ & $2.35 * * *$ \\
\hline $20 \mathrm{~m}$ & $1.56 * * *$ & $3.76 * * *$ & $2.26 * * * 3.78 * * *$ & $* 3.95 * * *$ & $1.69 * * *$ & $1.46^{* * *}$ & $1.82 * * *$ & $4.37 * * *$ & $1.62 * * *$ & $2.73 * * *$ \\
\hline $30 \mathrm{~m}$ & $2.32 * * *$ & $2.54 * * *$ & $2.41 * * * 3.45 * * *$ & $* 4.27 * * *$ & $3.16^{* * *}$ & $1.93 * * *$ & $2.21 * * *$ & $4.18 * * *$ & $2.73 * * *$ & $2.92 * * *$ \\
\hline
\end{tabular}

All coefficients that relate stock impact and operation volume ( $\alpha_{2}$ in Eqs II to IV) are significant at $1 \%$ for both buys and sales. Consistent with existing literature, there is a difference between the impact caused by purcahse and sale operations. The values for the purchase coefficients are significantly higher than those of the sale operations.
Finally, instead of analyzing only the immediate stock impact after the operation, we also investigate the impact 30 minutes after the end of its execution. Based on previous studies, our expectation is to find weaker results if compared to those of the immediate impact. Table 6 presents the results for immediate and permanent stock impacts. 
Table 6. Immediate and Permanent Impact on Stock Prices and Impact 30 Minutes After the End of the Operation and Operation Volume

This table shows the coefficients that relate stock impact and operation volume ( $\alpha_{2}$ in Eqs II to IV). Linear regressions are estimated and the dependent variable is the impact on stock prices at the end of the operation and 30 minutes after the end of the operation. The models are estimated using different aggregation intervals (1, 5, 10, 20 and 30 minutes), a cutoff value of $20 \%$ and operation volume is measured by the percentage in relation to the total volume negotiated during the day. Panels A and B show the results for the immediate and permanent impacts, respectively. $* * *$, ** and * indicate statistical significance at $1 \%, 5 \%$ and $10 \%$, respectively.

Pannel A: Impact Imediately after the End of the Operation

\begin{tabular}{|c|c|c|c|c|c|c|c|c|c|}
\hline $\begin{array}{l}\text { Stock / } \\
\text { Interval }\end{array}$ & Bradesco & Braskem & Cemig CSN & Eletrobras & Gerdau & Petrobras & Telemar & Usiminas & Vale \\
\hline $1 \mathrm{~m}$ & $1.55 * * *$ & $4.53 * * *$ & $3.43 * * * 2.17 * * *$ & $2.48 * * *$ & $2.58 * * *$ & $0.92 * * *$ & $0.93 * * *$ & $3.04 * * *$ & $1.72 * * *$ \\
\hline $5 \mathrm{~m}$ & $2.48 * * *$ & $4.20 * * *$ & $3.10 * * * 2.94 * * *$ & $3.12 * * *$ & $2.58 * * *$ & $1.10 * * *$ & $0.92 * * *$ & $3.04 * * *$ & $1.54 * * *$ \\
\hline $10 \mathrm{~m}$ & $2.55 * * *$ & $5.10^{* * *}$ & $3.81 * * * 2.65 * * *$ & $3.62 * * *$ & $2.85^{* * * *}$ & $0.86^{* * *}$ & $1.31 * * *$ & $2.86 * * *$ & $2.40 * * *$ \\
\hline $20 \mathrm{~m}$ & $2.88 * * *$ & $5.99 * * *$ & $4.62 * * * 3.06 * * *$ & $3.78 * * *$ & $4.28 * * *$ & $2.08 * * *$ & $1.94 * * *$ & $2.87 * * *$ & $3.17 * * *$ \\
\hline $30 \mathrm{~m}$ & $4.63 * * *$ & $6.43 * * *$ & $4.49 * * * 3.00 * * *$ & $3.76 * * *$ & $5.04 * * *$ & $1.32 * * *$ & $1.63 * * *$ & $4.53 * * *$ & $3.23 * * *$ \\
\hline \multicolumn{10}{|c|}{ Pannel B: Impact 30 Minutes after the End of the Operation } \\
\hline $\begin{array}{l}\text { Stock / } \\
\text { Interval }\end{array}$ & Bradesco & Braskem & Cemig CSN & Eletrobras & Gerdau & Petrobras & Telemar & Usiminas & Vale \\
\hline $1 \mathrm{~m}$ & 0.93 & $5.47 * * *$ & $3.76 * * * 1.75 * *$ & $3.80 * * *$ & $2.62 * * *$ & $0.73 * * *$ & 0.16 & $2.04 * * *$ & $1.66 * * *$ \\
\hline $5 \mathrm{~m}$ & $1.76^{*}$ & $3.17 * * *$ & $3.57 * * * 3.60 * * *$ & $2.54 * * *$ & $2.58 * * *$ & $1.00 * * *$ & $0.89 * * *$ & $2.27 * * *$ & $1.90 * * *$ \\
\hline $10 \mathrm{~m}$ & 0.53 & $6.72 * * *$ & $2.89 * * * 2.35 * * *$ & $3.70 * * *$ & $1.62 * * *$ & $0.93 * * *$ & $1.32 * * *$ & $1.35 * * *$ & $2.23 * * *$ \\
\hline $20 \mathrm{~m}$ & $5.15 * * *$ & $6.62 * * *$ & $5.05 * * * 3.05 * * *$ & $4.25 * * *$ & $3.93 * * *$ & $2.54 * * *$ & $2.13 * * *$ & $3.62 * * *$ & $3.92 * * *$ \\
\hline $30 \mathrm{~m}$ & $5.08 * *$ & $7.59 * * *$ & $4.40 * * * 2.46 * *$ & $3.28 * * *$ & $4.92 * * *$ & $1.33 * *$ & $1.63 * * *$ & $4.73 * * *$ & $3.12 * * *$ \\
\hline
\end{tabular}

By observing the number of significant coefficients it is possible to notice that the significance of the results for permanent impact is slightly lower than that of the immediate impact. However, the permanent impact continues to be significant in most cases. This result led us to also test the the permanent impact in longer periods (60 and 120 minutes after the execution of the operation). The results (not reported here) indicate that the significance falls substantially, practicaly eliminating the existence of significant coefficients.

\section{Conclusion}

There are numerous studies in international literature that analyze, on an intra-daily basis, the impact on stock prices decurring from high volume operations. In general, these are researches based on proprietary data provided by some investors and reveal in their findings the existence of a positive relation between the size of the operation and its impact on stock prices.

This paper analyzes the impact on stock prices of high volume operations executed in Brazil. It is groundbreaking work in the sense that it is based on publicly available data, with intra-daily information on 10 high liquidity stocks, from 2001 to 2006. In this regard, this paper differs from most studies found in the international literature.

Confirming previous observations, we have found that there are significant changes in stock prices after a high volume operation, be it a purcahse or a sale. Our results confirm the existence of temporary and partially permanent effects and of an asymmetry in the impacts caused by purchases and sales.

\section{References}

1. Almgren, R. (2003). Optimal execution with nonlinear impact functions and trading-enhanced risk, Applied Mathematical Finance, 10, 1-18.

2. Almgren, R., Thum, C, Hauptmann, E \& Li, H. (2005). Equity market impact, Journal of Risk, 18, 57-62.

3. Almgren, R. \& Chriss, N. (2000). Optimal execution of portfolio transactions, Journal of Risk, 3, 5-39.

4. Barclay, M. \& Warner, J. (1993). Stealth trading and volatility: which trades move prices?, Journal of Financial Economics, 34, 281-305.

5. Bhattacharya, U. \& Daouk, H (2002). The world price of insider trading, Journal of Finance, 57, 75-108.

6. Bikker, J., Spierdijk, L. \& Van der Sluis, P. (2007). Market impact costs of institutional equity trades, Journal of International Money and Finance, 26, 9741000 .

7. Blume, M., MacKinlay, C \& Terker, B. (1989). Order imbalances and stock price movements on October 19 and 20 1987, Journal of Finance, 44, 827-848.

8. Chan, L. \& Lakonishok, J. (1993). Institutional trades and intraday stock price behavior, Journal of Financial Economics, 33, 173-199.

9. Chan, L. \& Lakonishok, J. (1995). The behavior of stock prices around institutional trades, Journal of Finance, 50, 1147-1174.

10. Chiyachantana, C., Jain, P., Jiang, C. \& Wood, R. (2004). International evidence on institutional trading

$$
\text { VIRTUS } \frac{\text { NTERPRESS }_{100}}{100}
$$


behavior and price impact, Journal of Finance, 59, 869-898.

11. Domowitz, I., Glen, J. \& Madhaven, A. (2001). Liquidity, volatility, and equity trading costs across countries and over time, International Finance, 4, 221255.

12. Finucane, T. (2000). A direct test of methods for inferring trade direction from intra-day data, Journal of Financial and Quantitative Analysis, 35, 553-576.

13. Hasbrouck, J. (1988). Trades, quotes, inventories, and information, Journal of Financial Economics, 22, 229252.

14. Hasbrouck, J. (1991). Measuring the information content of stock trades, Journal of Finance, 46, 179207.

15. Holthausen, R., Leftwich, R. \& Mayers, D. (1987). The effect of large block transactions on security prices: a cross-sectional analysis, Journal of Financial Economics, 19, 237-267.

16. Jain, N. (2001). Monitoring costs and trade credit, Quarterly Review of Economics and Finance, 41, 89110.
17. Keim, D. \& Madhavan, A. (1997). Transaction costs and style: an inter-exchange analysis of institutional equity trades, Journal of Financial Economics, 46, 265-292.

18. Kraus, A. \& Stoll, H. (1972). Price impacts of block trading on the New York stock exchange, Journal of Finance, 27, 569-588.

19. Lee, C. \& Ready, M. (1991). Inferring trade direction from intraday data, Journal of Finance, 46, 733-746.

20. Madhavan, A. \& Cheng, M. (1997). In search of liquidity: block trades in the upstairs and downstairs markets, Review of Financial Studies, 10, 175-203.

21. Saar, G. (2001). Price impact asymmetry of block trades: an institutional trading explanation, Review of Financial Studies, 14, 1153-118.

22. Spierdijk, L., Nijman, E. \& Van Soest, A. (2002). The price impact of trades in illiquid stocks in periods of high and low market activity, Tilburg University Discussion Paper, 29. 


\title{
A CRITICAL EVALUATION OF THE SENSITIVITY OF A BANK'S BALANCE SHEET TO CHANGE WHEN OPTIMIZING FOR CAPITAL REQUIREMENTS UNDER BASEL
}

\author{
F Cronje*, J.H. van Rooyen**
}

\begin{abstract}
The management of a modern bank is a complex task that is becoming increasingly more so due to the inherent complexities of its business and of an ever changing modern financial environment. Recent turmoil in the global financial environment necessitated new regulation, some of which may have a material impact on the structure and management of a bank. The establishment of higher minimum capital buffers for banks to counter the possibility of failing will have a material influence on profitability. Apart from making investment in banks shares less attractive, the regulation may turn out to be bad for global economic growth. In view of the above, the objective of this research was to single out and demonstrate the effect of the minimum capital requirements on the profitability, composition and size of a bank balance sheet. The Simplex algorithm was used to set up a goal programming problem formulation in Excel. Different capital minima was entered in the model and then optimised to observe the effect on the bank balance sheet size, composition and profitability. The research clearly demonstrated that at a capital reserve requirements of $5 \%$, the resulting balance sheet is $190 \%$ of the original balance sheet size and at the $25 \%$ capital reserve requirement the new balance sheet is merely $57 \%$ of the original size. Increasing the reserve requirement from say $5 \%$ to $9,5 \%$ gives rise to approximately $40 \%$ change in balance sheet size, all other things being constant. As the capital reserve requirement is increased from $5 \%$ of RWA to $14 \%$, the profit falls from over R6o billion to just over R1o billion. It is clear from the research that banks are very sensitive to the new regulation. It also underlines how difficult it may be for banks to maintain profitability. The changes needed to maintain the profitability, may not be possible/feasible in the South African financial environment. The time is possibly right now for banks to start improving efficiency and developing new innovative low risk high return services and product lines.
\end{abstract}

Keywords: Capital; Reserves; Optimisation; Objective function; Liquidity

* Stellenbosch University, Department of Business Management, Private Bag X1, Matieland, 7602, South Africa

\section{Introduction and problem formulation}

The management of a modern bank is a complex task that is becoming increasingly more so due to the inherent complexities of its business and of an ever changing modern financial environment. This has recently again been underlined by the SubPrime crisis. The primary reasons why banks failed, was due to excessive risk taking which came in many different forms, for an example, undue credit granting to risky clients, excessive gearing, undue derivative risks and add to this the collective actions of many global banks. Due to the interrelated nature of global financial markets, banks were all affected in some way or another.

The primary risk that banks take is credit risk. It can easily be argued that the American banks set aside the very fundamental investment and business principles of being rewarded for taking high risk. Of course, human behaviour had a lot to do with the magnitude of the crisis. That is, for high risk, a high return is sought or that was what we were led to believe. The fundamental problem with the subprime loans was that these loans should, from a risk/return perspective, never have been granted in the first place. Put differently, credit granting standards deteriorated. The fundamental problem of these loans was that the borrower put very little or no equity into the loan agreement due to very limited private wealth. Due to this, excessively high loan to asset ratios (even 1) were needed to be able to grant these loans. This situation meant that banks were not rewarded for the risk they took. The problem is really that the lender (a bank) can, in case of default, fall back on a property that is already 100 per cent financed. Furthermore, the lender can also not add an interest premium to the loan rate to cater for the high risk as this will make repayments even more difficult for the borrower which may already be cash strapped. It is by now clear that this was, from a bank management perspective, an undesirable situation. 
Apart from the fact that undue credit was granted by many US banks, many other risks were also amplified after the crisis. Most important of these was liquidity risk. The credit problems led to large losses by highly levered banks which were exacerbated by loan defaults. This led to funding problems. Market liquidity deteriorated due to levered banks trying to lower leverage. In an attempt to lower counterparty exposure, banks started selling assets, hoarding cash and improving or tried improving their risk management processes/positions. All this gave rise to interbank funding problems with TED spreads widening. TED is the acronym derived from the T-bill and Eurodollar futures ticker which is ED. The TED spread is the difference between the interest rates on interbank loans and on short-term U.S. government debt ("T-bills"). The TED is an indication of the perceived credit risk in the general economy. An increase in the TED goes hand in hand with an economic downturn and lowering liquidity in the market.

Banks experienced funding liquidity problems which quickly spread, affecting highly levered hedge funds also creating funding risk for them where banks refuse to lend. The market illiquidity, the prospect of further liquidity risk and possible bank failures, scared investors. Prices dropped, especially those of illiquid assets with high margins. The crisis also spread across all asset classes and markets globally even affecting Covered Interest Rate Parity and the possibility for arbitrage.

Recent events in the global financial environment underlined just how vulnerable banks can be and just how easily they can fail - and they are certainly not too big to fail. The Basel III Accord, among others, proposes that banks increase the size and quality of their capital buffers to absorb losses. Apart from this, liquidity positions and management must also improve substantially in the years to come. Although increasing the capital buffers may seem to be the way for the future, it may, in the long run, not be the case. If the capital buffer is increased, banks will have to increase risk to increase the ROE. It won't be long before banks again start taking on more risk or will seek other innovative ways of bypassing regulatory requirements so as to deliver the ROE that owners want and in doing so, increase risk as these two things go hand in hand.

\section{Objectives of the research}

Since so many financial magnitudes affect the balance sheet of a bank simultaneously, knowing how the balance sheet should look in future is difficult to determine. The bank balance sheet is affected in a unique way by market factors. The degree of interaction between the asset and liability sides of the balance sheet is quite profound, more so than in case of any other businesses. However, we are fortunately not left entirely in the dark about the structure of the balance sheet. Many modern tools exist which may help us model and achieve some reasonable answer to the question of the structure of the balance sheet.

The objective of this research is briefly as follows:

- To develop a simple multi-objective, goal programming bank balance sheet model which will be used to demonstrate how the capital requirements will affect balance sheet size and profitability. The model will also demonstrate that the size of the capital buffer is not straight forward to determine.

- Another sub-objective of this research is that the model developed here, will serve as a prototype for the development of a more complex bank balance sheet planning model in the foreseeable future.

A discussion of aspects such as the effectiveness of some of the Basel measures is outside of the scope of this research. Financial aspects other than capital and profitability will not be covered in this research.

\section{Literature Review}

The recent financial crisis demonstrated just how interrelated and vulnerable financial markets can become. The collective actions and risks to which banks were exposed, underlined the weakness of the Basel II accord. This led to the third Basel Capital Accord (Basel III) which represents one of the biggest changes to banking regulations that the financial world has seen (Barfield, 2011:1). With the main aim of creating a resilient banking sector (BIS, 2010:1), this accord has been and is being implemented by the Basel Committee on Banking Supervision as a direct response to the recent financial crisis of 2007 (King \& Tarbert, 2011:1). According to Barfield (2011:10), banks entered into the financial crisis with insufficient capital, high leverage ratios, and financial assets carrying too high a level of risk. This led to a large number of bank bailouts and failures and resulted in the current unstable state of the banking sector. The Basel Committee plans to achieve its stated aims of resilience and financial stability (Barfiel, 2011:9) by strengthening regulations and raising requirements on capital and liquidity (BIS, 2011:1)(see Figure 1 below). 
Figure 1. A breakdown of the Basel III requirements

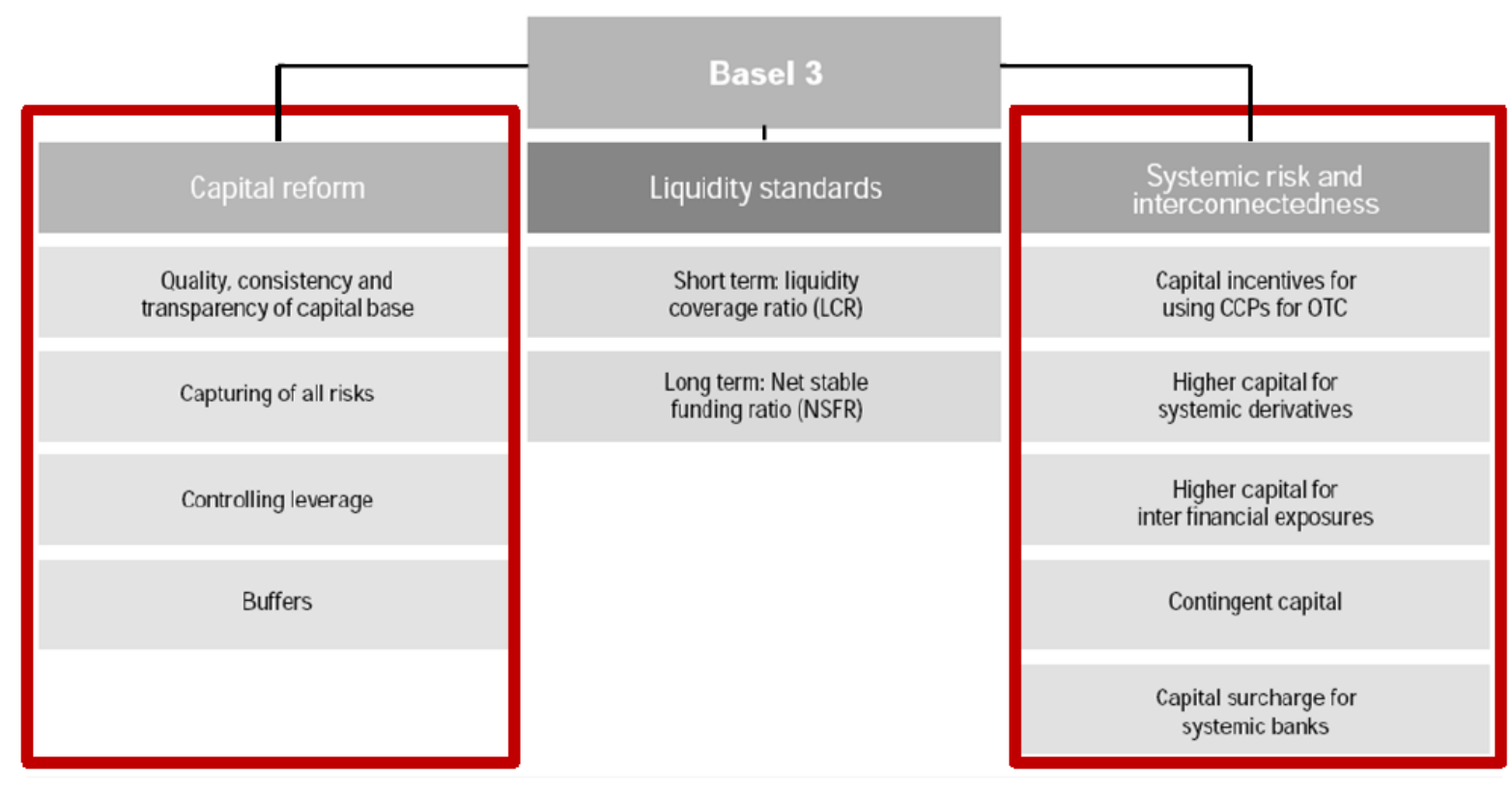

Source: $K P M G(2010: 9)$

The Basel Committee anticipates that new regulations will lead to a safer banking sector in the future, with banks holding elevated levels of capital and lower levels of risk (De La Mora, Matten \& Barfield, 2010:2). The Basel III regulations on capital could, however, have a negative impact for shareholders, consumers and bank profitability, and it may have a destabilising effect on the financial system (De La Mora, Matten \& Barfield, 2010:2).

The issue of bank capital management is not new to the banking sector. Since the initiation of the First Basel Accord in 1988, the Basel Committee has had the same objective of achieving a sound and stable international financial system (Jackson et al, 1999:1) and has used the same major technique of regulating bank capital to do so. The First Basel Accord was unsuccessful, and as a result, the second accord (Basel II) was implemented 26 years later (King \& Tarbert, 2011:1-2). The Basel Committee, however, also failed in this attempt (Blundell-Wignall \& Atkinson, 2010:5) due to the fact that the recent financial crisis severely affected the economy and left the banking sector unstable, despite the Basel II regulations being in place. From this, the Basel Committee has concluded that past regulations have been insufficient and that an even higher minimum capital requirement should be implemented. Although Basel III aims to improve on the earlier accords, their previous failures raised some doubt regarding the Basel Committee's approach and the effectiveness of continually raising capital requirements. The advantages of Basel III seem simple: holding a larger capital buffer will result in a banking sector that can easily absorb losses and remain stable in a period of financial distress (King \& Tarbert, 2011:3). Banking regulation is, however, complex and the costs involved with adhering to capital requirements frequently outweigh the seemingly obvious advantages. Under Basel III, banks will need to optimise their capital and carefully plan their actions in order to facilitate the crucial restructuring of the banking system and the resetting of their business models necessary to adjust to the revised capital regulations. This will inevitably have cost and time implications, resulting in the necessity for banks to start this process earlier rather than later (De la Mora, Matten \& Barfield, 2010:5). This immediate reaction is needed even though Basel III will only be fully implemented by 2019 (Chan, Masters and Hingel, 2010:1), with the requirements being gradually increased and enforced. According to the Basel Committee, the reason for this staggered implementation is to allow for economic recovery (King \& Tarbert, 2011:11) and also to give banks enough time to adjust to the regulations at the lowest possible cost (Kowalik, 2011:5). Although this seems beneficial, the main problem may concern the actual requirements, not merely the timeframe of implementation.

There is a substantial amount of information supporting, as well as criticising, capital requirements with numerous conflicting views. The Basel Committee has recently conducted a Quantitative Impact Study to assess the effects of the new regulations. This study has suggested that Basel III will have minimal negative effects (Lyons \& Casey, 2011:29) but this represents only one side of the capital requirement argument. This research 
discusses the (optimal) level of capital and determines the impact of the necessary bank reform, providing a critical view on Basel III. These regulations will affect a large number of banks on a global scale and it will, therefore, be beneficial for banks and governments, as well as investors, to be conscious of the impact thereof.

\section{Banks and capital requirements under Basel III}

A bank is a financial establishment that is based largely on leverage, with banks borrowing from the market and lending to borrowers (King and Tarbert, 2011:1). According to Kowalik (2011:1), banks fund their investments by using deposits, other debt and equity capital. Often not enough equity capital is held, because this represents money that cannot be invested to earn a return and is, thus, costly for banks (Paletta, 2010). Capital is an important and critical concept of banking and it can be defined as the portion of the bank's assets that is not contractually bound to make repayments (Elliot, 2010:3). The conventional role of capital is to ensure that banks can survive unexpected losses and that these losses can be absorbed internally without affecting the economy as a whole. This is, however, not the sole purpose of capital as excess reserves also play a fundamental role in the credit rating assigned to banks and the confidence of investors in the financial institution (Kjeldson, 2004). Higher credit ratings are assigned to banks with stronger capital positions and this leads to lower financing costs charged on interbank loans, as well as lower interest rates on bonds issued by the bank. Capital reserves also enable a bank to enter into large exposures without having to raise additional capital and maintain the reputation of the institution (Kjeldson, 2004). An aspect that should also be considered is a particular bank's appetite for risk and its policy towards risk taking. The risk culture in a bank has a lot to do with how it will deal with risk and how it maximises profit.

Regulations on bank capital aim to ensure that the excess reserves held by banks are sufficient to absorb losses and that these additional funds add value to the institution. According to the Basel Committee, it is crucial for banks to back their risks with a high quality and quantity of capital and this has resulted in the need for establishing the Basel Accord (BIS, 2010:2). Regulation is defined as a "set of rules and standards that govern financial institutions" (Barfield, 2011:5) and this is exactly what Basel III aims to do.

The key elements of the Basel III framework include:

\begin{tabular}{|c|c|}
\hline Type of capital & Percentage of RWA \\
\hline Minimum capital (Tier 1) & $4,5 \%$ \\
\hline Capital conservation buffer & $2,5 \%$ \\
\hline Counter cyclical buffer & $2,5 \%$ \\
\hline
\end{tabular}

Firstly, the new regulations require banks to hold a minimum level of capital, consisting entirely of Tier 1 capital, equivalent to $4.5 \%$ of risk weighted assets (BIS, 2010:12)(see Figure 2 below). Tier 1 capital is the highest quality, support-providing capital (Lyons \& Casey, 2011:1) and consists of common equity and retained earnings (Shearman \& Sterling.2011:4). Risk weighted assets (RWAs) involve the assignment of an inclusion percentage to assets based on their perceived level of risk (Kowalik.2011:2), with riskless assets carrying a weight of $0 \%$ (King \& Tarbert, 2011:1).

Figure 2. A breakdown of the total capital requirements compared under the Basel III and Basel II regulations

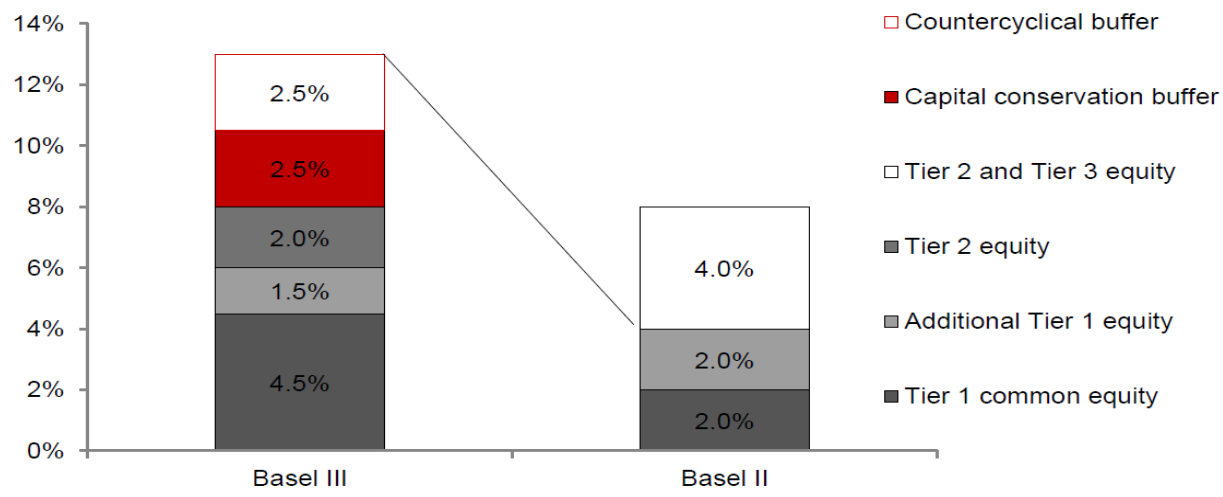


The fundamental definition of capital will be strengthened and applied uniformly on a global scale under Basel III (King \& Tarbert, 2011:3). The main aim of this is to ensure consistency and transparency amongst all internationally active banks.

The Basel Committee has identified additional regulations, which will be implemented over and above the minimum capital requirements, to close the loopholes evident in Basel II (The Economist, 2011:2). These additional requirements are comprised of a capital conservation buffer of $2.5 \%$ of RWAs and a countercyclical capital buffer of up to $2.5 \%$, depending on the state of the economy (Shearman \& Sterling, 2011:3). A leverage ratio of at least 3\% will also be introduced under Basel III (King \& Tarbert, 2011:6).

Setting the capital requirement at an appropriate level is a difficult task. If the capital requirements are too high, banks will become unprofitable. This will lead to an increased cost of borrowing, which will, in turn, slow down economic growth (The Economist, 2011:1). On the other hand, capital requirements set too low will lead to banks being vulnerable and susceptible to failure (The Economist, 2011:1). Many, vastly different opinions on the appropriate levels of capital exist. Miles, Yang and Marcheggiano (2011:40) believe that the capital requirement should be set at $20 \%$ of RWAs, almost triple the level suggested in Basel III. The banking industry, on the contrary, believes that the Basel III requirements, which have already almost tripled, are too high, with more modest changes being appropriate (Elliot, 2010:9).

The measurement of the required level of capital, in relation to RWAs, has also been identified as problematic. Firstly, the practice of assigning a risk weighting to assets has been widely criticised, with certain arguments suggesting the elimination of this approach altogether (King \& Tarbert, 2011:3). Basel III allows sophisticated banks to use internal risk models to determine various risk weightings and in doing so, ultimately determine the capital levels held (Elliot, 2011:8). The main problem with this approach is that weightings are often based on limited historical data and are determined in the bank's own interest (Elliot, 2011:8). These risk models are also often not stress-tested, resulting in insufficient capital in a financial crisis (The Economist, 2011:1) and a largely flawed system. Secondly, RWAs focus on individual assets and are, therefore, portfolio invariant. This is seen as a disadvantage because the importance of diversification is not reflected and the concentration of a portfolio in one asset is not penalised (Blundell-Wignall \& Atkinson, 2010:4). Basel III does not address the fundamental problems found regarding the use of RWAs as has become evident in the previous accords (BlundellWignall \& Atkinson, 2010:10).

The return on equity (ROE) is a measure of a bank's profitability in relation to shareholders' equity. This is a fundamental measure for shareholders as it indicates the quality of the shares and reveals how well a bank is utilising its funds to generate returns (Business: The Ultimate Resource, 2009). Banks should aim to keep their ROE as high as possible, but this proves to be difficult with the increase in equity required by the Basel III regulations. According to Barfield (2011:14), a falling ROE can negatively change the perception investors have of banks, and shareholders often fear that a bank is struggling when common equity is offered to the public (Kowalik, 2011:3). Issuing more equity also results in the dilution of shares values, which will not appeal to investors as their earnings per share will decrease. These factors make it difficult for banks to generate common equity and increase their Tier 1 capital, at a time when it is specifically required by regulations. Banks will be forced to take less desirable actions in order to meet requirements, while aiming to continue satisfying shareholders and minimising costs. Instead of issuing more capital, banks will be inclined to decrease the supply and increase the cost of loans to meet the Basel III standards (Kowalik, 2011:3) (Elliot, 2010:11). This will likely have a negative impact on economic growth and recovery.

Alternatively, banks can also attempt to maintain their ROE by raising profits, forming one of the main arguments against Basel III. Banks cannot earn a higher return through the use of risk free assets. These assets may have a $0 \%$ weighting with regard to RWAs (Kowalik, 2011:2) and, therefore, require no capital, but these assets also generate a low return. With the need to increase profitability, banks will move their funds to riskier parts of the economy (The Economist, 2011:1), being forced to hold higher levels of capital, but also being exposed to the possibility of earning higher returns. This, once again, causes problems for the stability of the banking sector and counteracts the safety created through the increase in capital, defeating the objectives of the Basel Accord as it relates to capital.

There is little dispute that the increased capital requirements will increase the cost of borrowing and in doing so, slow economic growth. There is, however, disagreement regarding the magnitude of the harm that Basel III will cause (The Economist, 2011:4). According to The Economist (2011), the Institute of International Finance estimates a decrease in economic growth of up to $0.9 \%$ per percentage point of capital held, while the New York Federal Reserve estimates a decrease of $0.09 \%$ and The Basel Committee expects even less than this. 
The slow economic growth expected under Basel III, can be attributed largely to the increased cost of borrowing, the decrease in loans offered, and the resultant plunge in the money supply (The Economist, 2011:4). Adjusting to capital ratios is costly for banks, and according to Kowalik (2011:5), banks prefer to raise their capital ratios by decreasing lending instead of increasing equity capital. This, however, could cause a credit crunch and will undoubtedly decrease economic growth (Kowalik, 2011:5) due to the lack of money in the financial system. The economy is presently in the process of recovering from the recent financial crisis and a slow economic growth is, therefore, undesirable in the current state of the financial sector. According to Professor Tim Congdon, the main reason for the decrease in the money supply and the failure to recover from the financial crisis to date, is that "regulators...are pressing banks to raise capital asset ratios and to shrink their risk assets" (Evans-Pritchard, 2010).

It is important to realise that banks take time to adjust to capital ratios (Kowalik, 2011:5) and as a result, the Basel Committee has designed a timeframe in which the regulations on capital are implemented gradually (Lyons \& Casey, 2011:1). Regardless of this, however, these regulations will be costly to banks and only really make sense in times of credit expansion and monetary growth (Brown, 2010). As the economy is currently in a trough, these ideal conditions do not exist and the new Basel Accord could ultimately harm the economy and limit growth, making this an important topic for discussion in the management of bank capital under Basel III.

\section{Additional requirements under Basel III}

The first and second Basel Accords focused solely on micro-prudential factors, but Basel III has implemented a range of additional requirements in order to attain a broader range of macro-prudential goals (King \& Tarbert, 2011:3). Over and above the minimum capital requirements discussed, conservation and countercyclical buffers, a leverage ratio, will be introduced (Lyons \& Casey, 2011:25). According to Ojo (2011:15), the conservation and countercyclical buffers have the main aim of protecting the banking system from a build-up of risk, which can be directly linked to excessive credit growth. These buffers essentially raise the capital requirements to an even higher level, and in doing so, exacerbate the possible harmful effects of Basel III on the banking system and the economy. The leverage ratio is supplementary to the basic Basel III requirements and acts to provide a last resort, or 'backstop' of support to the risk weighted capital requirements (Lyons \& Casey, 2011:24).
Additional requirements have been introduced under Basel III with the aim of achieving a resilient banking sector and a macro-prudential focus (King \& Tarbert, 2011:3). The conservation and countercyclical buffers increase the amount of capital banks are required to hold in an economic boom, resulting in capital reserves that can be used to absorb losses in an economic downturn (Kowalik, 2011:1). A leverage ratio has also been introduced to account for all on- and- off balance sheet leverage in an attempt to prevent the deleveraging of banks in a financial crisis (Lyons \& Casey, 2011:26). Although these additional requirements seem beneficial, they each have their own drawbacks in practice and essentially double the minimum capital requirement proposed. These buffers could have advantages, but it was necessary to determine if the costs outweigh the gains.

It was and is still evident that a large degree of uncertainty exists regarding the new capital requirements under Basel III. The Basel III framework proposes some fairly drastic changes and the reason that this research was undertaken was to form a clear, critical picture of the new regulations and their effects on the balance sheet only.

\section{Strategic Balance Sheet and Risk Management}

In the banking context, balance sheet management may briefly be defined as follows:

Balance sheet management entails considering conflicting and competing objectives such as maximization of income/profit as opposed to minimizing financial risks associated with alternative portfolios (Tayi \& Leonard : 1988). Although this definition is dated, it still applies today. However, the complexity of financial markets have drastically increased, markets in different countries are more integrated/linked together thereby influencing each other more than ever and all markets are more volatile. Financial products traded and offered to clients also had to become more complex due to the more complex management problems.

Looking at the liability side of the balance sheet, it is clear that the primary business activity of a bank entails receiving money (deposits) from the general public (retail market) which are loanable funds. Deposit activities are often intricately linked to economic activity (e.g. interest rates, propensity to save), product ranges offered, services offered and competition between banks.

Another important item on the liability side of the balance sheet is the capital and reserves (Tier 1 Capital). Capital refers to the capital raised from issued shares. Reserves represent the accumulative profit carried forward from one year to the next. The relative size of the capital and reserves is seen 
as very important to safeguard the bank against failure (as seen during the financial crisis) and is, at the same time, very controversial due to its effect on profitability. Increasing the issued share capital, of course, reduces the ROE. Increasing the capital buffer with the reserves component is dependent on the bank's ability to generate profits through its core business. Apart from the capital requirements, the new regulatory risk weighted assets, maturity matching and liquidity requirements limit the ability of banks to take on risk and increase the ROE/ROA. To complicate thing even more, the economic environments have undergone change, leading to the reduced ability of clients (whether corporate of private) to save.

The following important item on the liability side of the balance sheet is borrowed funds which is often used as a long-term source of funds. It is also used to leverage the return on the shareholder's funds, if the bank succeeds in earning more with the borrowed funds than what it pays for it.

On the asset side of the balance sheet the primary source of income is from loans and advances which may make up anything between 70 and 80 percent or even more of the total balance sheet. The loans and advances are quite diverse. These include secured loans such as housing loans, unsecured loans such as credit card loans, loans to corporates and personal loans. Other assets are funds locked up in cash, traded instruments (e.g. bonds, derivatives) and other investments.

When a bank attempts to manage its balance sheet on a strategic level, that is, over an extended planning period of say 36 to 60 months, it needs to look at the source(s) of funds, how much can it get hold of and how those funds will be allocated to the different asset classes that will generate its income. Over this planning period, the bank should also consider how it would want to change its position in the market to gain competitive advantage and gain market share or reposition it so that it may substantially reduce risk or say introduce new profitable product lines. It therefore has to consider how to strategically allocate the funds to different asset classes on a risk and return basis. Funds may be allocated to these classes in accordance with various factors that are usually linked to the economic environment and the bank's own internal constraints and management policies. In South Africa, the financial markets and the change that the markets can undergo, is limited due to the size of the market and the profile of the depositors.

The interaction between the asset and liability sides of the balance sheet, in the case of a bank, is unique. The structure of both sides of the balance sheet has to be considered together. Of course, the starting point of the balance sheet planning is to decide what funds the bank may in future receive (wholesale or retail). However, it is not to say that the bank should let the balance sheet constantly increase in size or grow. It may even want to reduce the size of the balance sheet to be able to maintain the ROE, the capital requirements and liquidity requirements. In the next section the model will be formulated. This is then followed up by an illustration of the model outcomes and a brief discussion.

\section{Balance sheet planning model formulation}

As the models that may be formulated to determine the future balance sheet structure, may vary substantially in terms of complexity and focus, it stands to reason that the most important variables that will materially influence the future position and profitability of the bank, must be used within the framework of the requirements of Basel III. It is not possible to consider all possible variables as this would make the model exceedingly complex. Any additional benefits that will be gained with additional complexity may be very marginal. Increased complexity may also lead to increased model risk.

The primary objective of an optimization model may, on the one hand, be to maximize the shareholder's wealth. On the other hand, the bank should attempt to minimize risk within a given framework. If risk is minimized, the return on equity is affected negatively. The purpose of this research is to elucidate the questions about the capital buffer level only.

The research instrument utilised in order to collect primary data in this investigation takes the form of a simple, single objective linear programming model developed in Microsoft Excel. A model is defined as a "representation of a [real world] system that is constructed to study some aspect of the system as a whole" (Blumberg, 2011:36).

The model utilised in this research operated by inputting a summarised bank balance sheet (of ABSA bank in particular) into Microsoft Excel and allowing this financial statement to be modified and projected in order to optimise the allocation of assets and liabilities and equity under various scenarios while maintaining the RWA and liquidity regulatory requirements. Symbols have the following meaning:

$\mathrm{A}=$ Asset

$\mathrm{L}=$ Liability

$\mathrm{RW}_{\mathrm{i}}=$ Asset risk weight for $\mathrm{A}_{\mathrm{i}}$

$R_{i}=$ Per period interest rate for asset $A_{i}$ or

liability $L_{i}$ for period $j$

$\mathrm{m}=$ number of liabilities and equity

$\mathrm{n}=$ number of assets

$\mathrm{o}=$ number of goals

$\mathrm{i}=\mathrm{i}_{\text {th }}$ asset or liability 

period

$\mathrm{j}=\mathrm{j}_{\text {th }}$ period $\mathrm{j}$ of the planning or forecasting

$\mathrm{s}=$ short-term

$\mathrm{m}=$ medium-term

$1=$ long-term

\section{Objective function:}

A standard optimisation model would attempt to optimize the net interest income as follows:

$$
\mathrm{Z}=\operatorname{Max}\left(\sum_{i=1}^{n}\left(A_{j} x R_{j}\right)-\sum_{i=1}^{m}\left(L_{j} x R_{j}\right)_{-}^{-}\right.
$$

However, a simple, goal programming model formulation requires that the model "optimizes" the balance sheet by minimizing the deviations ( $d_{j}^{+}, d_{j}^{-}$- from the stated goals. The user sets a goal for net interest income. The model then is used to structure a future balance sheet that will be as close to the profit goal as possible. Therefore, for this research, the following objective function was minimized:

The objective function is restated as follows:

$$
\mathrm{Z}=\operatorname{Min} \quad \sum_{i=1}^{o}\left(d 1_{j}^{+}+d 1_{j}^{-}\right)
$$

Where $\mathrm{d} 1$ is the deviation variable applicable to goal 1 for period $\mathrm{j}$. The plus sign " + " indicates an over achievement of goal 1 for period $j$. The negative sign indicates an under achievement of goal 1 for period $\mathrm{j}$.

Subject to all decision variables being nonnegative:

$$
\mathrm{A}, \mathrm{L} \geq 0
$$

\begin{tabular}{|c|c|}
\hline Line item in balance sheet (decision variables) & $\begin{array}{l}\text { Decision variable value determined by lower and or } \\
\text { upper bound or equal to constraint }\end{array}$ \\
\hline \multicolumn{2}{|l|}{$\begin{array}{l}\text { Liabilities: Other than deposits and capital (not } \\
\text { changed by LP model. Balances are kept static and } \\
\text { equal to the opening balance sheet values.) }\end{array}$} \\
\hline Deposits from banks & $\mathrm{L} 1 \mathrm{j}=$ opening balance \\
\hline Trading liabilities & $\mathrm{L} 2 \mathrm{j}=$ opening balance \\
\hline Derivative liabilities & $\mathrm{L} 3 \mathrm{j}=$ opening balance \\
\hline Hedging liabilities & $\mathrm{L} 4 \mathrm{j}=$ opening balance \\
\hline Deposits: Short-term & No limitation: $\mathrm{L} 5 \mathrm{sj} \geq 0$ \\
\hline Deposits: Medium-term & No limitation: $\mathrm{L} 5 \mathrm{mj} \geq 0$ \\
\hline Deposits: Long-term & No limitation: $\mathrm{L} 5 \mathrm{lj} \geq 0$ \\
\hline Debt securities in issue & L6j = opening balance \\
\hline Normal tax & $\mathrm{L} 7 \mathrm{j}=$ opening balance \\
\hline Liabilities under investment contracts & L8j = opening balance \\
\hline $\begin{array}{l}\text { Policyholder liabilities under } \\
\text { insurance contracts }\end{array}$ & L9j = opening balance \\
\hline Borrowed funds & L10j = opening balance \\
\hline Other liabilities and sundry provisions & $\mathrm{L} 11 \mathrm{j}=$ opening balance \\
\hline Deferred tax liabilities & $\mathrm{L} 12 \mathrm{j}=$ opening balance \\
\hline Share premium - Preference shares & $\mathrm{L} 13 \mathrm{j}=$ opening balance \\
\hline $\begin{array}{l}\text { Shareholder's equity: Capital and accumulated reserves } \\
\text { at end of period } j\end{array}$ & $\begin{array}{l}\sum_{i=1}^{n} R_{j} A_{j}-\sum_{i=1}^{m} R_{j} L_{j}-\left(\mathrm{L} 14_{\text {(opening) }} \mathrm{x}(1+\text { per }\right. \\
\text { period } \mathrm{ROE} \% \text { for period } \mathrm{j})=0\end{array}$ \\
\hline Minority interest & L15j = opening balance \\
\hline Minority - Barclays & L16j = opening balance \\
\hline
\end{tabular}

Table 1. Mathematical formulation for decision variables 


\begin{tabular}{|l|l|}
\hline Assets: Loans and advances and other assets & \\
\hline Cash, cash balances and balances with central banks & $\mathrm{L} 1 \mathrm{j} \geq \%$ of $\sum_{i=1}^{m} L j$ \\
\hline Statutory liquid asset portfolio & $\mathrm{L} 2 \mathrm{j} \geq \%$ of $\sum_{i=1}^{m} L j$ \\
\hline Loans and advances to banks & $\mathrm{A} 3 \mathrm{j}=$ opening balance \\
\hline Trading assets & $\mathrm{A} 4 \mathrm{j}=$ opening balance \\
\hline Derivative assets & $\mathrm{A} 5 \mathrm{j}=$ opening balance \\
\hline Total hedging assets & $\mathrm{A} 6 \mathrm{j}=$ opening balance \\
\hline Loans and advances to customers - short term & No limitation: A7s $\geq=0$ \\
\hline Loans and advances to customers - medium term & No limitation: A7mj $\geq=0$ \\
\hline Loans and advances to customers - long term & No limitation: A7lj $\geq=0$ \\
\hline Reinsurance assets & $\mathrm{A} 8 \mathrm{j}=$ opening balance \\
\hline Other assets & $\mathrm{A} 9 \mathrm{j}=$ opening balance \\
\hline Investments & $\mathrm{A} 10 \mathrm{j}=$ opening balance \\
\hline Subsidiary shares & $\mathrm{A} 11 \mathrm{j}=$ opening balance \\
\hline $\begin{array}{l}\text { Investments in associated undertakings and joint } \\
\text { ventures }\end{array}$ & $\mathrm{A} 12 \mathrm{j}=$ opening balance \\
\hline Intangible assets & $\mathrm{A} 13 \mathrm{j}=$ opening balance \\
\hline Property and equipment & $\mathrm{A} 14 \mathrm{j}=$ opening balance \\
\hline Current tax assets & $\mathrm{A} 15 \mathrm{j}=$ opening balance \\
\hline Deferred tax assets & $\mathrm{A} 16 \mathrm{j}=$ opening balance \\
\hline
\end{tabular}

Table 2. Mathematical formulation of other additional constraints

\begin{tabular}{|c|c|}
\hline \multicolumn{2}{|l|}{ Accounting constraint } \\
\hline Total assets $=$ total liabilities & $\sum_{i=1}^{n} A j-\sum_{j=1}^{m} L j=0$ \\
\hline $\begin{array}{l}\text { Level of liabilities of planned balance sheet is } \\
\text { equal to the level of the opening balance sheet }\end{array}$ & $\sum_{i=1}^{m} L_{(\text {opening })}=\sum_{i=1}^{m} L_{j}$ \\
\hline \multicolumn{2}{|l|}{ Regulatory constraints: } \\
\hline \multicolumn{2}{|l|}{ Maintenance of capital buffer } \\
\hline $\begin{array}{l}\text { Capital asset ratio (CAR): Shareholder's capital }+ \\
\text { retained earnings }+ \text { forecast period growth must be } \geq \\
\text { prescribed } \% \text { of Risk Weighted Assets (RWA) }\end{array}$ & 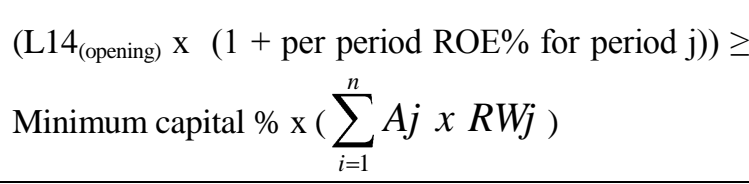 \\
\hline \multicolumn{2}{|l|}{ Maturity Mismatch } \\
\hline $\begin{array}{l}\text { Short-term loans must be a percentage of short-term } \\
\text { liabilities }\end{array}$ & AL5sj $-\%$ of $L 7 \mathrm{sj}=0$ \\
\hline $\begin{array}{l}\text { Medium-term loans must be a percentage of medium- } \\
\text { term liabilities }\end{array}$ & AL5mj $-\%$ of $L 7 m j=0$ \\
\hline $\begin{array}{l}\text { Long-term loans must be a percentage of long-term } \\
\text { liabilities }\end{array}$ & AL5lj $-\%$ of $L 7 l j=0$ \\
\hline
\end{tabular}

It is important to note that the Deposits due to customers and Loans and advances to customers are left open to fluctuate. All these decision variables have lower bounds only, i.e. they are set $\geq 0$. The size of the balance sheet is therefore dependant only on the level at which the model can satisfy the profit goal (minimise the deviations), satisfy the accounting and regulatory (capital buffer and liquidity) constraints. All balances other than loans and deposits are set equal to the opening balance sheet values. It is assumed that all other balances stay static, i.e. do not change over the entire 
planning period of one year. Although this is unrealistic, it is done to observe the change in the compositing of the main interest earning liabilities and assets and ultimately the effect of certain changes in important variables on the balance sheet size, profit and balance sheet composition.

The Basel capital implications are mainly implemented in this model. The Liquidity Coverage Ratio (LCR), Net Stable Funding Ratio (NSFR) is not considered. However, liquidity is considered only to a limited extent as indicated above. The final outcome and relationship between assets and liabilities should, however, be very similar to implementing LCR and NSFR.

\section{The data}

The final results of ABSA Bank Limited as at 31 December 2012, was used in this research. A simplified balance sheet is used as illustrated below. The only adjustment made to the balance sheet was to split Loans and advances to customers and Deposits due to customers into short-, mediumand long-term line items. The sub-values are fictitious. However, the totals still balance with the original balance sheet. This was done to implement a maturity mismatch constraint as indicated in the previous section under problem formulation. Apart from the balances, the table also indicates the percentages of funds locked up in the different categories of the balance sheet.

Table 3. The data

Cash, cash balances and balances with central banks Statutory liquid asset portfolio

Loans and advances to banks

Trading assets

Derivative assets

Total hedging assets

Loans and advances to customers

Loans and advances to customers

Loans and advances to customers

Reinsurance assets

Other assets

Investments

Subsidiary shares

Investments in associated undertakings and joint ventures Intangible assets

Property and equipment

Current tax assets

Deferred tax assets

Deposits from banks

Trading liabilities

Derivative liabilities

Hedging liabilities

Deposits due to customers - short term

Deposits due to customers - medium term

Deposits due to customers - long term

Debt securities in issue

Normal tax

Liabilities under investment contracts

Policyholder liabilities under insurance contracts

Borrowed funds

Other liabilities and sundry provisions

Deferred tax liabilities

Share premium - Preference shares

Minority interest

Minority - Barclays

Capital and reserves attributable to equity holders:

Profit

Profit deviation $(\mathrm{d} 1+)$

Profit deviation (d1-)

TOTAL

\begin{tabular}{|c|c|c|}
\hline Proportion & Opening BS 2012/1/1 & Interest rate \\
\hline $3.217 \%$ & 24847409691 & $4.00 \%$ \\
\hline $4.278 \%$ & 33042731034 & $5.00 \%$ \\
\hline $6.038 \%$ & 46634312485 & $5.00 \%$ \\
\hline $1.744 \%$ & 13471867777 & $7.00 \%$ \\
\hline $8.468 \%$ & 65406817026 & $7.00 \%$ \\
\hline $0.406 \%$ & 3139370276 & $7.00 \%$ \\
\hline $4.165 \%$ & 32170759269 & $8.00 \%$ \\
\hline $25.893 \%$ & 200000000000 & $9.00 \%$ \\
\hline $38.839 \%$ & 300000000000 & $10.00 \%$ \\
\hline $0.117 \%$ & 902782419 & $0.00 \%$ \\
\hline $2.187 \%$ & 16892880183 & $0.00 \%$ \\
\hline $3.513 \%$ & 27132760936 & $0.00 \%$ \\
\hline$-0.195 \%$ & -1509589231 & $10.00 \%$ \\
\hline $0.278 \%$ & 2144009946 & $0.00 \%$ \\
\hline $0.124 \%$ & 957289028 & $0.00 \%$ \\
\hline $0.890 \%$ & 6874905352 & $0.00 \%$ \\
\hline $0.008 \%$ & 59537710 & $0.00 \%$ \\
\hline $0.031 \%$ & 243055853 & $0.00 \%$ \\
\hline $7.558 \%$ & " 54928315291 & $3.00 \%$ \\
\hline $0.654 \%$ & 4751267937 & $4.00 \%$ \\
\hline $9.355 \%$ & 67985815297 & $8.00 \%$ \\
\hline $0.149 \%$ & 1079764107 & $8.00 \%$ \\
\hline $11.322 \%$ & 82281091291 & $3.00 \%$ \\
\hline $13.760 \%$ & 100000000000 & $4.00 \%$ \\
\hline $27.521 \%$ & 200000000000 & $5.00 \%$ \\
\hline $22.828 \%$ & 165899975378 & $0.00 \%$ \\
\hline $0.060 \%$ & 434157291 & $0.00 \%$ \\
\hline $1.428 \%$ & 10376919854 & $0.00 \%$ \\
\hline $0.423 \%$ & 3076208062 & $7.00 \%$ \\
\hline $1.692 \%$ & 12296353503 & $8.75 \%$ \\
\hline $1.807 \%$ & 13131045705 & $0.00 \%$ \\
\hline $0.390 \%$ & 2834841649 & $0.00 \%$ \\
\hline $0.639 \%$ & 4643930718 & $0.00 \%$ \\
\hline $0.143 \%$ & 1042035781 & $0.00 \%$ \\
\hline $0.270 \%$ & 1962843519 & $0.00 \%$ \\
\hline $6.287 \%$ & 45686334368 & $0.00 \%$ \\
\hline $0.000 \%$ & 0 & $0.00 \%$ \\
\hline $0.000 \%$ & 0 & $0.00 \%$ \\
\hline $0.000 \%$ & 0 & $0.00 \%$ \\
\hline \multicolumn{3}{|c|}{$\begin{array}{ll}\mathbf{0} & \mathbf{0}\end{array}$} \\
\hline
\end{tabular}




\section{Empirical results}

The model was used to illustrate the relationship between the balance sheet size, the profit and risk taking by the bank for different levels of capital. A controversial question is, what should the level of capital be that a particular bank (or all banks generally) should hold as a buffer. Basel prescribes the minima as discussed above. The effect of changing this requirement is addressed in this research. However, the safe level of capital (for a particular bank) is really a function of many things such as the risk policy, current risk profile (Tier 1 and 2 capital and reserves) and the future strategy of the bank within a certain market context. A lengthy discussion of these aspects, fall outside of the scope of this research. However, the point should be made that the level of risk that any bank wants to take on is dependent on its appetite for risk. What any bank therefore views as the optimal capital level is relative and dependant on its strategic goals. This optimal level of capital is not the same as the minimum prescribed by Basel.

The first aspect that is modelled is the impact of change in the capital reserve requirement on the size of the balance sheet. Figure 2 below seems to indicate an exponential decrease in balance sheet size, with the size of the balance sheet falling rapidly at a capital requirement less that $11 \%$ and decreasing more gradually thereafter. At a capital reserve requirements of $5 \%$, the resulting balance sheet is $190 \%$ of the original balance sheet size, and at the $25 \%$ capital reserve requirement the balance sheet is merely $57 \%$ of the original size. Increasing the reserve requirement from say $5 \%$ to $9,5 \%$ gives rise to approximately $40 \%$ change in balance sheet size, all other things being constant.
In order to maintain the capital buffer requirement, the model adjusts the size of the balance sheet. The size adjustment is largely due to a decrease in the loans extended to customers on the asset side of the balance sheet and fewer deposits accepted on the equity and liability side of the balance sheet. In order to meet the capital buffer (through the RWA percentages) and different yields on short-, medium and long-term loans, the volumes of these items are adjusted by the model. From the data collected it is evident that banks will have to completely reduce medium and long term loans to R0 in order to meet the capital reserve requirements optimally. Figure 3 illustrates that short-term loans will also be decreased drastically as the reserve requirement increases. These decreases require significant and often costly restructuring within the banking system and could also have a significant impact on the economy if banks withdraw from this market. This is a strategic issue that banks will have to evaluate carefully.

Since banks will not be able to adjust their balance sheets much due to market and internal constraints (even less so over the short term), they will have to find other ways to increase profit. Efficiency, among other things, will probably be one way to improve profit. Instead of focusing on extending the balance sheet and increasing/decreasing the total assets held, banks will have to reduce their assets and function more efficiently if they hope to meet the capital requirements while trying to stay liquid and maintaining an acceptable profitability level for the owners. Another way for banks to increase profitability is to move into new services which bear relatively low risk with a promise of a high payoff. An example would be extended electronic services due to improved technology.

Figure 2. The percentage change in the size of the balance sheet in comparison to the original when a capital reserve is implemented (holding all else static)

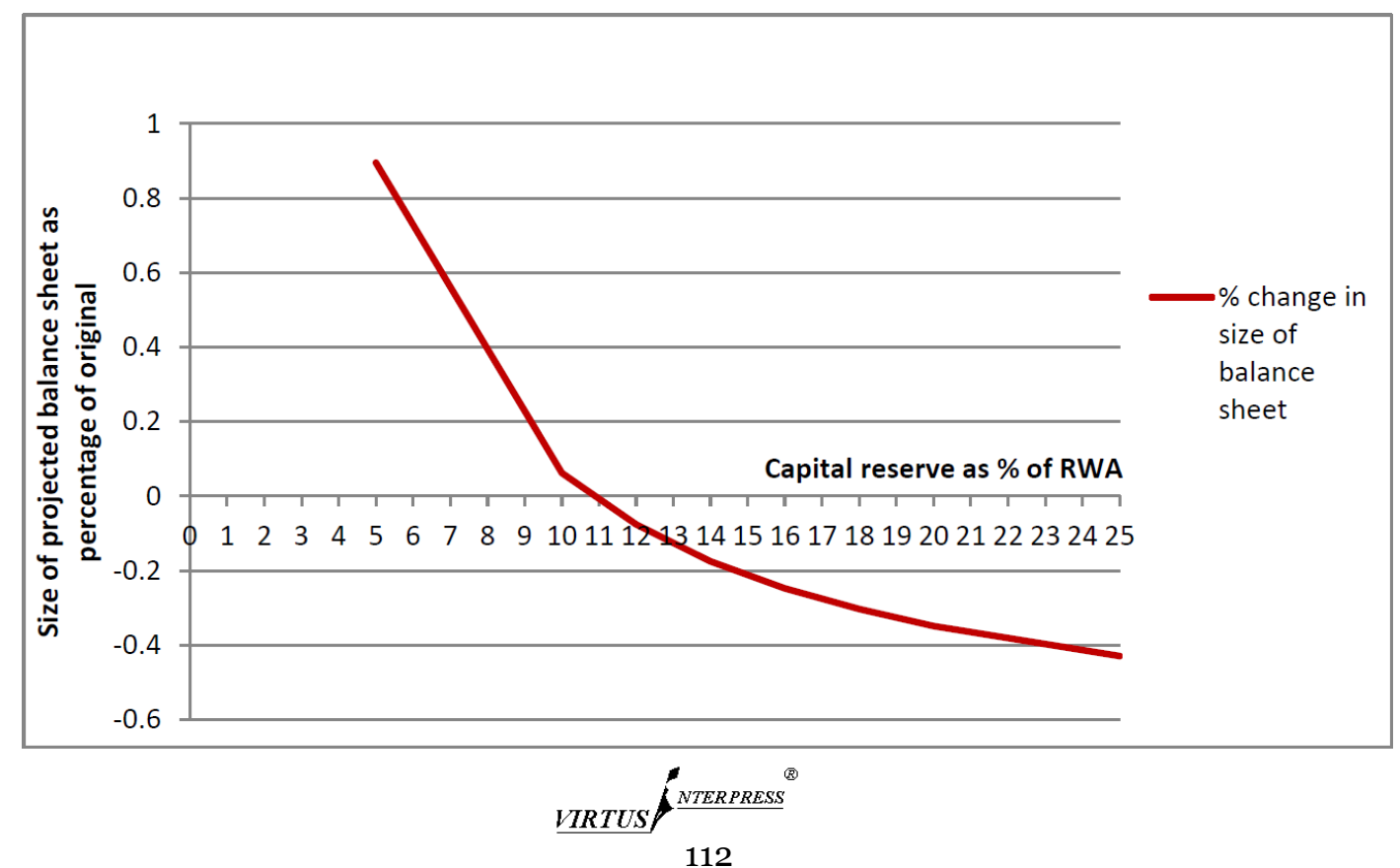


Figure 3. The change in the value of short-term loans as an increased capital reserve requirement is implemented

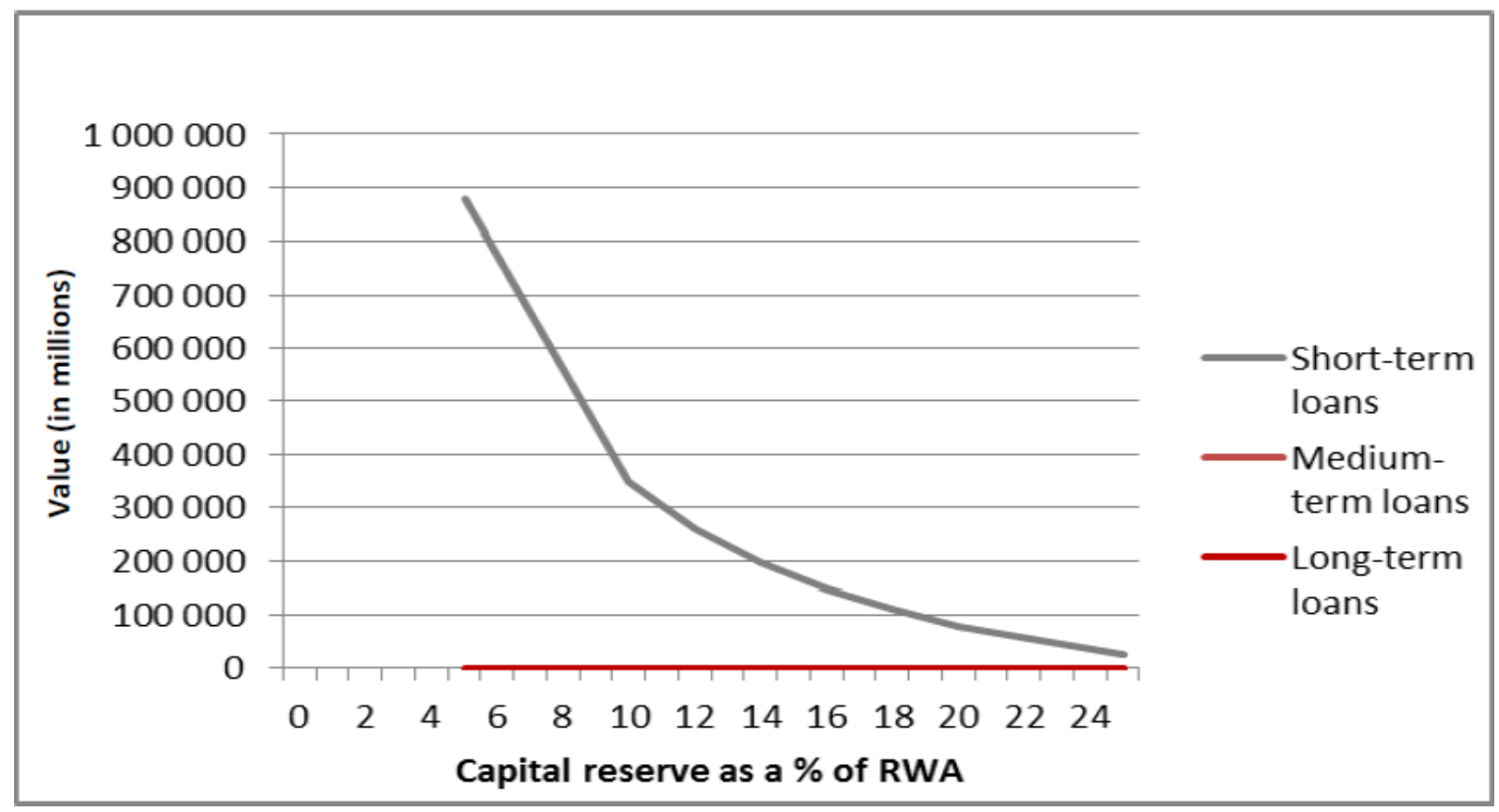

The next aspect considered is the effect of the capital buffer requirements on the risk weighted assets (see Figure 4 below). Table 2 clearly indicates how the loan balances, which easily make up 70 to 80 percent of the total assets, behave as the reserve requirement is increased. From Table 2 it is evident that the largest constituent of the RWA are short-term loans to customers. These assets have risk-weightings (for this research) ranging between $50 \%$ and $100 \%$. From this table it can, therefore, be concluded that banks will have to take on less loans as the capital requirements are increased, assuming that the capital buffer is not be increased in any other way than through profit for the year. If capital increases only by the current year's profit, the reduced higher yielding loans volumes will have a negative impact on profit and ROE. This is demonstrated in Figure 5 below. If the bank wants to maintain the ROE at all cost, it will have to increase the size of the balance sheet (see Figure 2) in order to achieve this target, an option which may turn out to require unrealistic funding. Apart from annual reserve growth, the growth of the balance sheet can only be achieved by a high deposit growth rate or by increasing the borrowed funds.
It may be concluded, tentatively, that, banks may want to invest in riskier assets (as they yield more) as a result of the Basel increased capital requirements due to pressure from shareholders to maintain profitability. Investing in riskier assets requires more capital which can only be acquired through new issue of shares, or reserves earned over time. Alternatively, the balance sheet size has to shrink if no reserves and or capital will be obtained.

In this investigation, the RWA decreased as the capital reserve requirement increased. This was largely due to the shrinking balance sheet and the fact that the reserve value (increased only by the current year's profit of $25 \%$ ) was kept constant at R57 107917 960. As in Figure 2, depicting the percentage change in the size of the balance sheet, the value of the RWA also falls exponentially with increasing requirements. If RWA is calculated as a percentage of total assets, however, there is a far more linear relationship between the RWA and the required capital. This can be seen in Figure 4 below. 
Figure 4. The change in RWA and the capital reserve held by banks when increased capital reserve requirements are implemented

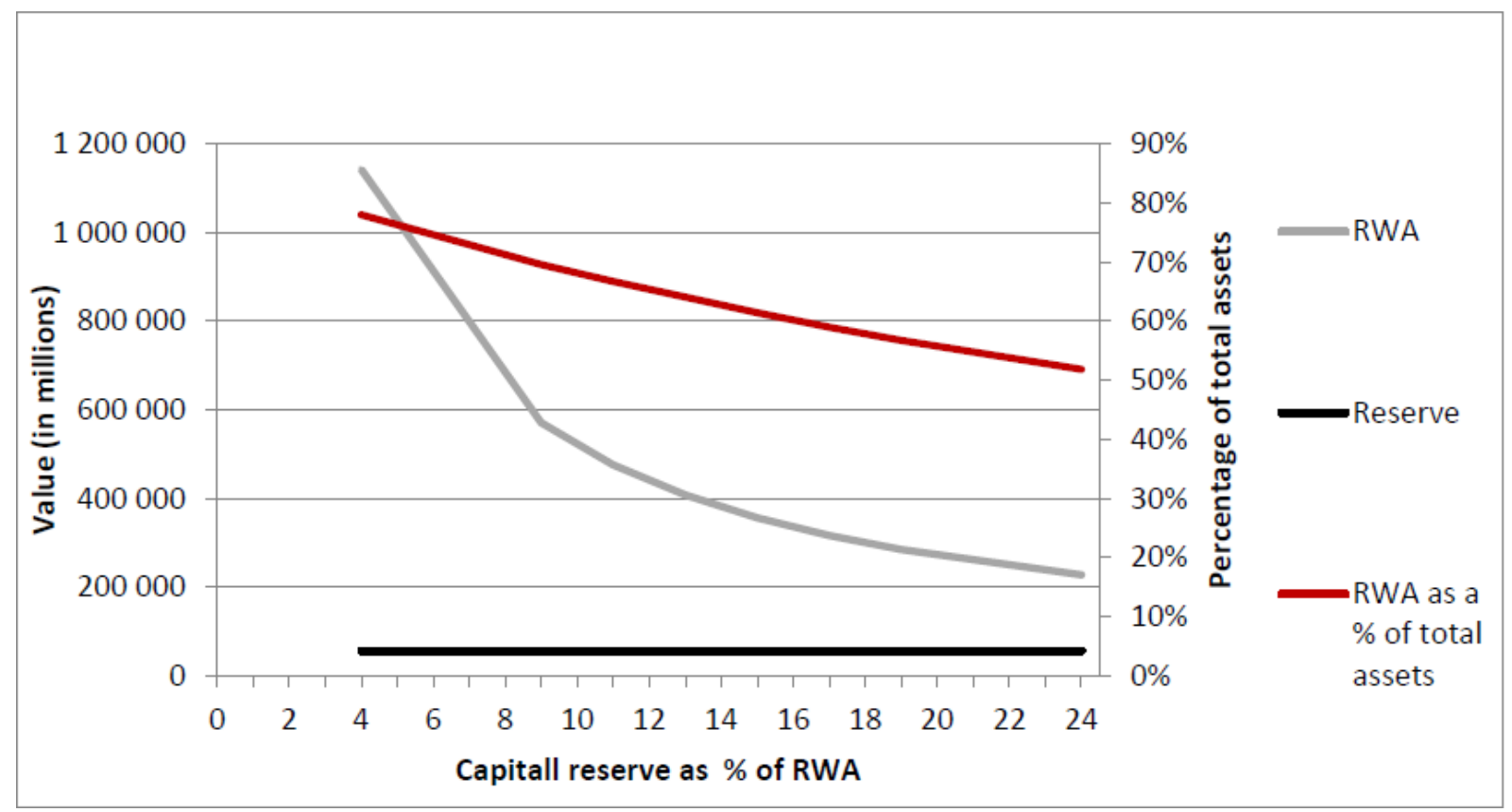

Table 2. The constituents of the total RWA at various capital reserve requirements

\begin{tabular}{|l|r|r|r|r|r|r|r|r|r|}
\hline & Ret. & $\mathbf{5 . 0 0 \%}$ & $\mathbf{1 0 . 0 0 \%}$ & $\mathbf{1 2 . 0 0 \%}$ & $\mathbf{1 4 . 0 0 \%}$ & $\mathbf{1 6 . 0 0 \%}$ & $\mathbf{1 8 . 0 0 \%}$ & $\mathbf{2 0 . 0 0 \%}$ & $\mathbf{2 5 . 0 0 \%}$ \\
\hline Cash \& central bank balances & $4 \%$ & $0.15 \%$ & $0.16 \%$ & $0.17 \%$ & $0.17 \%$ & $0.18 \%$ & $0.18 \%$ & $0.19 \%$ & $0.20 \%$ \\
\hline Statutory liquid asset portfolio & $5 \%$ & $1.13 \%$ & $1.20 \%$ & $1.23 \%$ & $1.26 \%$ & $1.28 \%$ & $1.31 \%$ & $1.33 \%$ & $1.39 \%$ \\
\hline Loans and advances to banks & $5 \%$ & $2.93 \%$ & $3.23 \%$ & $3.35 \%$ & $3.47 \%$ & $3.57 \%$ & $3.68 \%$ & $3.78 \%$ & $4.04 \%$ \\
\hline Trading assets & $7 \%$ & $2.47 \%$ & $2.30 \%$ & $2.23 \%$ & $2.16 \%$ & $2.08 \%$ & $2.00 \%$ & $1.92 \%$ & $1.71 \%$ \\
\hline Derivative assets & $\mathbf{7} \%$ & $12.34 \%$ & $11.49 \%$ & $11.15 \%$ & $10.81 \%$ & $10.40 \%$ & $9.99 \%$ & $9.58 \%$ & $8.55 \%$ \\
\hline Total hedging assets & $7 \%$ & $0.27 \%$ & $0.55 \%$ & $0.66 \%$ & $0.77 \%$ & $0.88 \%$ & $0.99 \%$ & $1.10 \%$ & $1.37 \%$ \\
\hline Loans to customers (short) & $\mathbf{8} \%$ & $76.97 \%$ & $61.06 \%$ & $54.69 \%$ & $48.31 \%$ & $41.46 \%$ & $34.60 \%$ & $27.75 \%$ & $10.61 \%$ \\
\hline Loans to customers (medium) & $9 \%$ & $0.00 \%$ & $0.00 \%$ & $0.00 \%$ & $0.00 \%$ & $0.00 \%$ & $0.00 \%$ & $0.00 \%$ & $0.00 \%$ \\
\hline Loans to customers (long) & $10 \%$ & $0.00 \%$ & $0.00 \%$ & $0.00 \%$ & $0.00 \%$ & $0.00 \%$ & $0.00 \%$ & $0.00 \%$ & $0.00 \%$ \\
\hline Reinsurance assets & $\mathbf{0} \%$ & $1.07 \%$ & $14.68 \%$ & $20.12 \%$ & $25.42 \%$ & $26.17 \%$ & $26.91 \%$ & $27.66 \%$ & $29.53 \%$ \\
\hline Other assets & $0 \%$ & $0.74 \%$ & $1.48 \%$ & $1.77 \%$ & $2.07 \%$ & $2.37 \%$ & $2.66 \%$ & $2.96 \%$ & $3.70 \%$ \\
\hline Investments & $0 \%$ & $1.19 \%$ & $2.38 \%$ & $2.85 \%$ & $3.33 \%$ & $3.80 \%$ & $4.28 \%$ & $4.75 \%$ & $5.94 \%$ \\
\hline Subsidiary shares & $10 \%$ & $0.00 \%$ & $0.00 \%$ & $0.00 \%$ & $0.17 \%$ & $5.46 \%$ & $10.75 \%$ & $16.04 \%$ & $29.27 \%$ \\
\hline Investments in associates & $0 \%$ & $0.09 \%$ & $0.19 \%$ & $0.23 \%$ & $0.26 \%$ & $0.30 \%$ & $0.34 \%$ & $0.38 \%$ & $0.47 \%$ \\
\hline Intangible assets & $0 \%$ & $0.04 \%$ & $0.08 \%$ & $0.10 \%$ & $0.12 \%$ & $0.13 \%$ & $0.15 \%$ & $0.17 \%$ & $0.21 \%$ \\
\hline Property and equipment & $0 \%$ & $0.60 \%$ & $1.20 \%$ & $1.44 \%$ & $1.69 \%$ & $1.93 \%$ & $2.17 \%$ & $2.41 \%$ & $3.01 \%$ \\
\hline Current tax assets & $0 \%$ & $0.00 \%$ & $0.00 \%$ & $0.00 \%$ & $0.00 \%$ & $0.00 \%$ & $0.00 \%$ & $0.00 \%$ & $0.00 \%$ \\
\hline Deferred tax assets & $0 \%$ & $0.00 \%$ & $0.00 \%$ & $0.00 \%$ & $0.00 \%$ & $0.00 \%$ & $0.00 \%$ & $0.00 \%$ & $0.00 \%$ \\
\hline RISK WEIGHTED ASSETS & & $100 \%$ & $100 \%$ & $100 \%$ & $100 \%$ & $100 \%$ & $100 \%$ & $100 \%$ & $100 \%$ \\
\hline \hline
\end{tabular}

Profitability is an important aspect to consider. From figure 5 it is evident that the proposed Basel III capital requirements could have a fairly significant impact on the profit level realised in the financial sector. As the capital reserve requirement is increased from $5 \%$ of RWA to $14 \%$, the profit falls from over R60 billion to just over R10 billion. At a capital reserve requirement of higher than $14 \%$, the profit level remains constant and a minimum floor level of profit is essentially created. 
The drastic decline in the profit invariably arises due to the decrease in the size of the balance sheet with increasing capital stringency. As the balance sheet shrinks, fewer assets are held and, therefore, fewer returns are earned for the bank. This decrease in returns may cause banks to invest in (assumedly) riskier assets in order to increase profitability.

Figure 5. The impact of capital requirements on profit levels

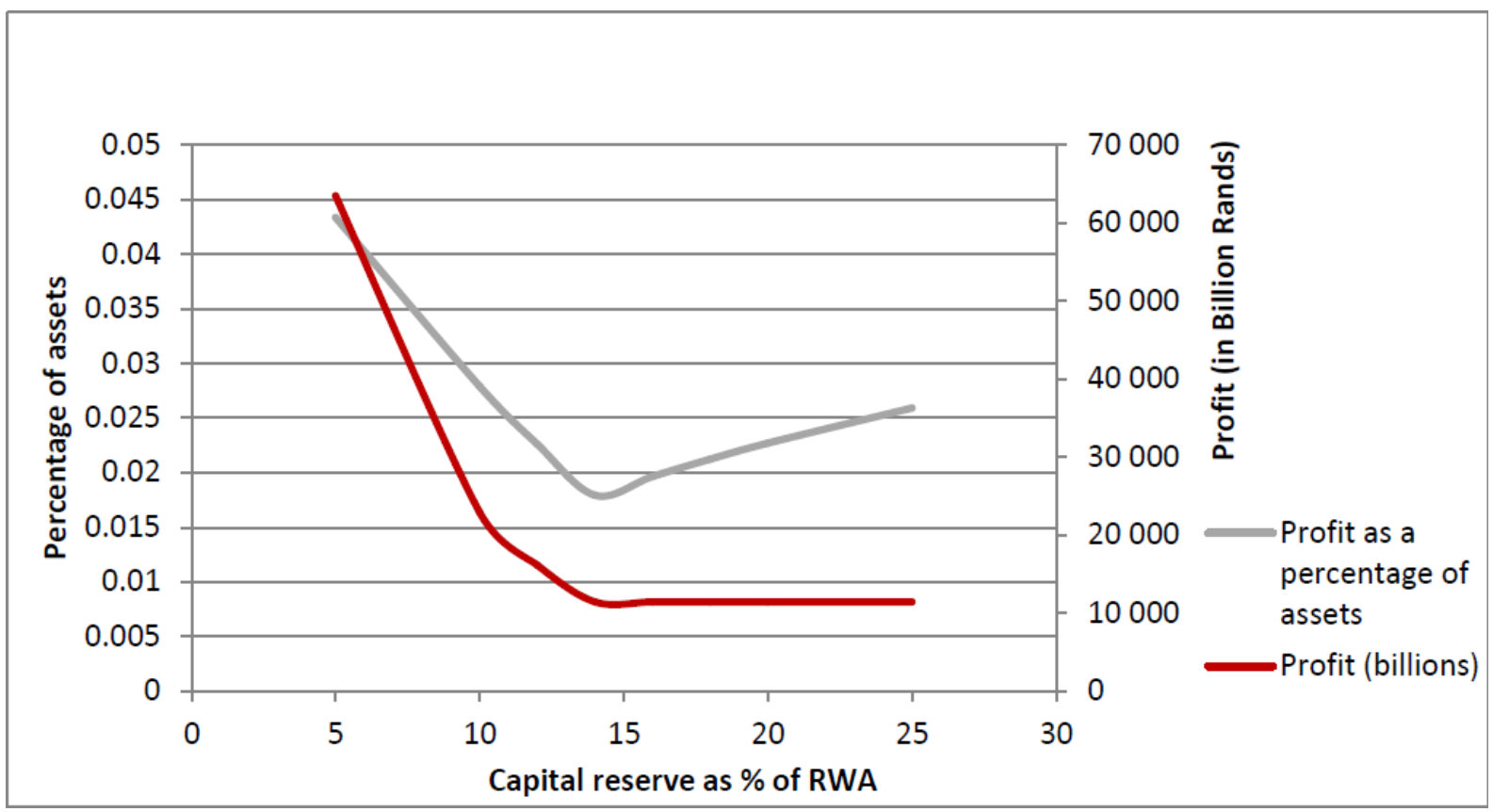

\section{Summary and conclusion}

It was explained that as the capital buffer requirements increase, more of the loans balances have to be set aside as capital. In order for the bank to do this, the balances of assets with high risk weightings have to be kept constant to adhere to the capital reserve requirement. The total RWA's are limited by current capital and reserves, which can only increase due to the issuing of additional shares or due to profit realized and carried over to capital and reserves. In these results we see conflicting outcomes. To increase the profit and ROE, the bank has to invest in higher yielding assets which, of course, is more risky and carries higher risk weightings and in the end require more capital and reserves. If the banks want to maintain the ROE at all cost (given an increased CAR), it will have to increase the size of the balance sheet while investing in lower yielding, lower risk assets. If it wants to maintain the ROE but invest in higher risk higher yielding assets, it will have to decrease the balance sheet size. The first alternative may turn out to be unrealistic in the given market conditions. The second alternative may also take time to implement and may be met with resistance.

The question that needs to be answered is: what minimum level of capital should banks maintain? Setting the minimum level of capital as a percentage of RWA's seems to be too a simplistic approach. However, it seems from the observed results that the answer should depend on the risk that an individual bank is willing to take, its current risky position and also on what the market is capable of sustaining, which is very limited in the economy. It also seems as though the banks are caught up between a rock and a hard place. A bank can achieve basically anything as long as it is willing and able to change the input variables. It does seem that the most viable alternative is for banks to focus on being true bankers again and to start focusing on value added services and efficiency.

Many more models can be developed to determine the "optimal" level of capital. However, in the end the answer really has to do with qualitative issues such as bank management in general. Basel III attempts to, among other aspects, set the general level of capital that all banks must maintain now and in future. Is it not really treating the symptoms rather than the problems? The attitude of managers when it comes to taking risk is forgotten - think of the highly geared banks that failed after the financial crisis. Should bank managers not also be held accountable for the way that they deal with funds that belong to other people? Should they not also be prevented from practicing as bankers/bank managers if they are found guilty of unethical practices (including taking undue risk)? Should Basel not also prescribe volumes of investment in certain asset classes or limit risk taking in the first instance? Should certain 
product lines such as housing loans not rather be granted by a specialised organization such as SA Home Loans where long term funding can more easily be matched with long term lending?

A lot has been implied above. But, let us not forget how inefficient and unproductive banks can sometimes be. Improving the current business model may go a long way towards increasing or at least maintaining ROE in spite of the Basel III requirements. On the other hand, should shareholder not accept that banks will in future, possibly, have to achieve lower returns?

\section{References}

1. Barfield, R., 2011. Introduction. In Barfield, R (ed). A Practitioner's Guide to Basel III and Beyond. London: Sweet \& Maxwell.

2. Basel Committee on Banking Supervision., 2010. Basel III: A global regulatory framework for more resilient banks and baking systems, Basel, Switzerland: Bank for International Settlement.

3. Basel Committee on Banking Supervision., 2010b. Calibratine regulatory minimum capital requirements and buffers: a top down approach, Basel, Switzerland: Bank for International Settlement.

4. Blumberg, B., Cooper, DR. \& Schindler, S., 2011. Business Research Methods. United Kingdom: McGraw-Hill Education.

5. Blundell-Wignall, A. \& Atkinson, P., 2010. Thinking beyond Basel III: necessary solutions for capital and liquidity. OECD Journal: Financial Market Trends, 2010(1):1-23.

6. Brown, E., 2010. Trapped in the spiral of Basel III. Tightening the noose on credit spells disaster. [Online] Available: www.globalresearch.ca/ index.php?context =va\&aid=21091 [2012, 5 March].

7. Calculating Return on Shareholders' Equity. 2009. BUSINESS: The Ultimate Resource. [Online]. London: A\&C Black Available: http://www.credoreference.com.ez.sun.ac.za/ entry/ultimatebusiness/calculating_return_on_sharehold ers_equity [2012, 21 March.]

8. Chan, WK.,Masters, B. \& Hingel, G., 2010. Basel III: The impact on bank capital. Financial Times, [Online] Available: www.ft.com/cms/s/0/a526e482-ec0e-11dfb50f-00144feab49a.htm. [2012, 12 February].

9. De La Mora, F.,Mattem, C. \& Barfield, R., 2010. Capital management in banking: the way forward. $P w C$ The Journal, [Online] Available: http://www.pwc.com/gx/en/banking-capital-markets/ pdf/capital-management.pdf. [2012, 12 February].

10. Elliot, DJ., 2010. Basel III, the Banks and the Economy. The Brookings Institution.

11. Evans-Pritchard, A., 2010. US money supply plunges at 1930s pace as Obama eyes fresh stimulus. The Telegraph, [Online] Available: http://www.telegraph.co.uk/finance/economics /7769126/US-money-supply-plunges-at-1930s-pace-asObama-eyes-fresh-stimulus.html [2012, March 20]

12. How much is enough? Capital. 2011. The Economist. 14 May.

13. Jackson, P., Furfine, C., Groeneveld, H., Hancock, D., Jones, D., Perraudin, W., Radecki, L. \& Voneyama, M., 1999. Capital requirements and banking behaviour: the impact of the Basle Accord. Basle, Switzerland: Bank for International Settlement, Basle Committee on Banking Supervision Working Papers 1/1999.

14. Jones, S., 2012. Hedge funds face higher trading costs. Financial Times. [Online]. Available: http://www.ilghirlandaio.com/ftp/telpress/21230326021 54601655.pdf. [2012, $26 \mathrm{March}]$

15. King, P. \& Tarbert, H., 2011. Basel III: an overview. Banking and Financial Services Policy Report, 30(5):118.

16. KPMG. 2010. Basel III Pressure is building.... [Online]. Available: http://www.kpmg.com/BH/en/ Documents/Basel\%203-\%20Pressure $\% 20$ is $\% 20$ building\%E2\%80 \%A6.pdf [2012, 20 April]

17. Kowalik, M., 2011. Countercyclical capital regulation: should bank regulators use rules of discretion? Economic Review (Kansas City), Spring: 63.

18. Lyons, G. \& Casey, CE., 2011. Basel III-an initial piece of the global puzzle. Banking and Financial Services Policy Report, 30(7):21-30.

19. Miles, D.,Yang, J. \& Marcheggiano, G., 2011. Optimal Bank Capital. London: Bank of England, External MPC Unit Discussion Paper 31/2011.

20. Ojo, M., 2011. Basel III-Responses to Consultative Documents, Vital Aspects of the Consultative Processes and the Journey Culminating to the Present Framework. Banking and Financial Services Policy Report, 30(10):15-34.

21. Paletta, D., 2010. Inching toward world-wide accord on bank rules. [Online]. Available: http://online.wsj.com/articla/SB1000142405274870341 8004575455822415872894.html [2012, 21 March]

22. Shearman \& Sterling. 2011. The new Basel III Framework: Implications for Banking Organization. [Online]. Available: http://www.shearman.com/files/ Publication/f4e80b99-f0a1-4e3a-90f0-

3bf21c7d0ce0/Presentation/PublicationAttachment/8d4 e19cc-1ba3-4501-8fe6-63a66 33d5b6b/FIA-033011The_new_Basel_III_framework___ Implications _for_banking_organizations. pdf [2012, 9 March]

23. Standard \& Poor's., 2011. Why Basel III and Solvency II will hurt corporate borrowing in Europe more than in the U.S. Global Credit Portal: Ratings Direct. [Online]. Available:

http://www.agrusdelassurance.com/mediatheque/9/6/2/ 000011269.pdf. [2012, 1 April]. 


\section{SUBSCRIPTION FORM \\ TO "CORPORATE OWNERSHIP \& CONTROL", "CORPORATE BOARD: ROLE, DUTIES \& COMPOSITION", "RISK GOVERNANCE \& CONTROL: FINANCIAL MARKETS \& INSTITUTIONS", “JOURNAL OF GOVERNANCE AND REGULATION"}

Copy this form and follow guidelines to fill it up. I would like to buy (underline what you choose):

For individual subscribers:

1. Journal of Corporate Ownership \& Control:

1.1. Printed version of the journal - US\$260 / €220.

1.2. Electronic version - US\$185 / €150.

2. Corporate Board: role, duties \& composition:

2.1. Printed version of the journal - US\$240 / €190.

2.2. Electronic version - US $\$ 180 / € 145$.

3. Risk Governance \& Control journal: financial markets \& institutions:

3.1. Printed version of the journal - US $\$ 240 / € 190$.

3.2. Electronic version - US $\$ 180 / € 145$.

4. Journal of Governance and Regulation:

3.1. Printed version of the journal - US\$240 / €190.

3.2. Electronic version - US $\$ 180$ / €145.

For institutional subscribers:

1. Journal of Corporate Ownership \& Control:

1.1. Printed version of the journal and electronic subscription - US\$1240 / €890.

1.2. Printed version of the journal - US\$1080 / €790.

1.3. Electronic version - US\$730 / €650.

2. Corporate Board: role, duties \& composition:

2.1. Printed version of the journal and electronic subscription - US\$820 / €760.

2.2. Printed version of the journal - US\$960 / €720.

2.3. Electronic version - US $\$ 650$ / €590.

3. Risk Governance \& Control journal: financial markets \& institutions:

3.1. Printed version of the journal and electronic subscription - US $\$ 920 / € 790$.

3.2. Printed version of the journal - US\$860 / €620.

3.3. Electronic version - US\$550 / €490.

3. Journal of Governance and Regulation:

3.1. Printed version of the journal and electronic subscription - US\$920 / €790.

3.2. Printed version of the journal - US $\$ 860 / € 620$.

3.3. Electronic version - US\$550 / €490.

Underline one of the payment methods you prefer, and write amount to pay (if you prefer, you can pay by one cheque/bank transfer to subscribe to both journals):

1. I enclose a cheque for US\$ / $€$

2 . Send me an invoice for US $\$ / €$ (indicate currency correctly).

Write your contact details here:

Name

Position

Institution

Address

E-mail Tel Fax

Please, send this form (with a cheque if you prefer to pay by cheque) at:

Dr. Alexander Kostyuk

Publishing house "Virtus Interpress"

Postal Box 36

Sumy

40014

Ukraine

1 Ask for invoice by fax at $+380-542-698125$ (if you want to pay by bank transfer).

2 Enter our web-site to download the subscription form at www.virtusinterpress.org.

If you prefer, you can subscribe through our global subscription agents - SWETS INFORMATION SERVICES of EBSCO. 


\section{LIBRARY RECOMMENDATION FORM PLEASE FORWARD THIS FORM TO YOUR INSTITUTION FOR ORDER CONSIDERATION}

To: Subject Librarian

From:

Title:

Department:

Email:

I would like the library to order the titles selected below:

- Corporate Governance: An International Outlook - ISBN 978-966-96872-2-7 (390 pages, year of publishing - 2011, authors: Dr. Alexander Kostyuk, Professor at Ukrainian Academy of Banking (Ukraine), Dr. Carsten Gerner-Beuerle, Professor at London School of Economics (The UK), Dr. Rodolfo Apreda, Professor at Universidad del CEMA (Argentina) - price - EURO 56

Number of copies -

- Anti-Crisis Paradigms of Corporate Governance in Banks: a new institutional outlook ISBN978-966-96872-0-9 (482 pages, year of publishing - 2010, authors - Alexander N. Kostyuk, Fumiko Takeda, Kaoru Hosono, introduced by Oliver Williamson, a Nobel Prize Winner 2009 - price - EURO 68

Number of copies -

- Corporate Governance: a textbook - ISBN978-966-96872-0-3 (400 pages, year of publishing 2007, authors - Alexander N. Kostyuk, Udo C. Braendle, Rodolfo Apreda) - price - EURO 58

Number of copies -

- Corporate Governance in a Transition Economy: a monograph - ISBN966-96566-0-5 (155 pages, year of publishing - 2005, author - Alexander N. Kostyuk) - price - EURO 38

Number of copies -

- Corporate Board Practices: a monograph - ISBN966-96566-1-3 (156 pages, year of publishing 2006, author - Alexander N. Kostyuk) - price - EURO 38

Number of copies -

- Euroasian Perspectives Of The Banking Systems Development - ISBN 978-966-96872-2-7 (170 pages, year of publishing - 2011, authors: Dr. Oleksandr Kostyuk, Dr. Michelle Lin, Dr. Ghassan Omet - price - EURO 24

Number of copies -

I want to order all books in the list. Total price - EURO 255.

I recommend this book(s) for the following reasons:

- I need to refer to this information frequently in the course of my work.

- This book(s) is directly related to my field and is an important source of information for my research.

- It is critical that students have access to this information to best facilitate their course work and academic pursuits.

- This is an obligatory course book

- Additional reasons:

Signature: Date :

Information on these books may be obtained from the Publisher's Website:

http://www.virtusinterpress.org

Please send all orders and inquiries to:

Publishing company "Virtus Interpress"

Postal Box 36

40014

Sumy, Ukraine

E-mail: alex_kostyuk@virtusinterpress.org

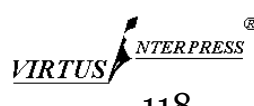

